\title{
UNDERSTANDING DISABILITY THROUGHOUT HISTORY
}

\section{INTERDISCIPLINARY PERSPECTIVES IN ICELAND}

\section{FROM SETTLEMENT TO 1936}

Edited by Hanna Björg Sigurjónsdóttir and James G. Rice

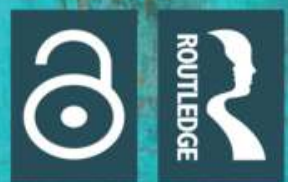




\section{Understanding Disability Throughout History}

Understanding Disability Throughout History explores seldom-heard voices from the past by studying the hidden lives of disabled people before the concept of disability existed culturally, socially, and administratively.

The book focuses on Iceland from the Age of Settlement, traditionally considered to have taken place from 874 to 930, until the 1936 Law on Social Security (Lög um almannatryggingar), which is the first time that disabled people were referenced in Iceland as a legal or administrative category. Data sources analysed in the project represent a broad range of materials that are not often featured in the study of disability, such as bone collections, medieval literature, and census data from the early modern era, archaeological remains, historical archives, folktales and legends, personal narratives, and museum displays. The ten chapters include contributions from a multidisciplinary team of experts working in the fields of Disability Studies, History, Archaeology, Medieval Icelandic Literature, Folklore and Ethnology, Anthropology, Museum Studies, and Archival Sciences, along with a collection of postdoctoral and graduate students.

The volume will be of interest to all scholars and students of disability studies, history, medieval studies, ethnology, folklore, and archaeology.

Hanna Björg Sigurjónsdóttir is a Professor of Disability Studies at the School of Social Sciences, University of Iceland. She received her doctorate in disability studies from the University of Sheffield in 2005. She is the Principle Investigator for the Disability before Disability project funded by the Icelandic Research Fund.

James G. Rice is an Associate Professor of Anthropology at the School of Social Sciences, University of Iceland. He received his doctorate in anthropology from the Memorial University of Newfoundland in 2007. He is currently the Lead Researcher in the project "Disability, immigration, and multigeneration: intersecting factors in child protection cases," funded by the University of Iceland's research fund. 


\section{Interdisciplinary Disability Studies}

Series Editor: Mark Sherry, the University of Toledo, USA

Disability studies have made great strides in exploring the power and the body. This series extends the interdisciplinary dialogue between disability studies and other fields by asking how disability studies can influence a particular field. It will show how a deep engagement with disability studies changes our understanding of the following fields: sociology, literary studies, gender studies, bioethics, social work, law, education, or history. This ground-breaking series identifies both the practical and theoretical implications of such an interdisciplinary dialogue and challenges people in disability studies as well as other disciplinary fields to critically reflect on their professional praxis in terms of theory, practice, and methods.

\section{Disability, Intersectional Agency, and Latinx Identity}

Theorizing LatDisCrit Counterstories

Alexis Padilla

Disability and Art History From Antiquity to the Twenty-First Century

Edited by Ann Millett-Gallant and Elizabeth Howie

Disability Representation in Film, TV, and Print Media

Edited by Michael S. Jeffress

Accessibility Denied. Understanding Inaccessibility and Everyday Resistance to Inclusion for Persons With Disabilities

Hanna Egard, Kristofer Hansson, and David Wästerfors

\section{Understanding Disability Throughout History}

Interdisciplinary Perspectives in Iceland From Settlement to 1936

Edited by Hanna Björg Sigurjónsdóttir and James G. Rice

For a full list of titles in this series, please visit: www.routledge.com/series/ ASHSER1401 


\section{Understanding Disability Throughout History}

Interdisciplinary Perspectives in Iceland from Settlement to 1936

\section{Edited by}

Hanna Björg Sigurjónsdóttir and James G. Rice 
First published 2022

by Routledge

2 Park Square, Milton Park, Abingdon, Oxon OX14 4RN

and by Routledge

605 Third Avenue, New York, NY 10158

Routledge is an imprint of the Taylor \& Francis Group, an informa business

(C) 2022 selection and editorial matter, Hanna Björg Sigurjónsdóttir and James G. Rice; individual chapters, the contributors

The right of Hanna Björg Sigurjónsdóttir and James G. Rice to be identified as the authors of the editorial material, and of the authors for their individual chapters, has been asserted in accordance with sections 77 and 78 of the Copyright, Designs, and Patents Act 1988.

The Open Access version of this book, available at www.taylorfrancis. com, has been made available under a Creative Commons AttributionNon Commercial-No Derivatives 4.0 license.

Trademark Notice: Product or corporate names may be trademarks or registered trademarks and are used only for identification and explanation without intent to infringe.

British Library Cataloguing-in-Publication Data

A catalogue record for this book is available from the British Library

Library of Congress Cataloguing-in-Publication Data

A catalogue record has been requested for this book

ISBN: 978-1-032-01827-0 (hbk)

ISBN: 978-1-032-01782-2 (pbk)

ISBN: 978-1-003-18018-0 (ebk)

DOI: $10.4324 / 9781003180180$

Typeset in Times NR MT Pro

by KnowledgeWorks Global Ltd. 


\section{Contents}

Foreword vii

Acknowledgements ix

List of contributors $\quad \mathrm{x}$

Introduction 1

HANNA BJÖRG SIGURJÓNSDÓTTIR AND JAMES G. RICE

1 Disability in Medieval Iceland: Some methodological concerns 12 CHRISTOPHER CROCKER, YOAV TIROSH, AND ÁRMANN JAKOBSSON

2 Beneath the Surface: Disability in archaeological and osteobiographical contexts

STEINUNN KRISTJÁNSDÓTTIR AND JOE W. WALSER III

3 One Story, One Person: The importance of micro/bio research for disability studies

SIGURĐUR GYLFI MAGNÚSSON

4 The Peculiar Attitude of the People: The life and social conditions of one "feebleminded" girl in the early 20th century

GUĐRÚN V. STEFÁNSDÓTTIR AND SÓLVEIG ÓLAFSDÓTTIR

5 From a Life With a Different Body to a Recreated Folklore of Accentuated Difference: Sigríður Benediksdóttir versus Stutta-Sigga

EVA PÓRDÍS EBENEZERSDÓTTIR AND SÓLVEIG ÓLAFSDÓTTIR

6 Dis-/abling Absence: Absencepresence as matters that matter 
vi Contents

7 Health, Healing, and the Social Body in Medieval Iceland 113 CHRISTOPHER CROCKER AND YOAV TIROSH

8 Physical Impairment and the Spatial Dimensions of Everyday Life in Rural Households in Pre-industrial Iceland ÓLAFUR RASTRICK

9 Guðmundur Bergbórsson as Creator and Creation: A Folk Narrative Study of a 17th Century Disabled Poet

ALICE BOWER

10 Fictive Osteobiographical Narrative - The Missing Puzzle Pieces HARALDUR THOR HAMMER HARALDSSON 


\section{Foreword}

\section{Rannveig Traustadóttir}

What a privilege it is to write the foreword for this important volume! It is an excellent contribution to disability studies, at the same time as it brings into view how a range of scholarly disciplines can provide valuable insights and perspectives to the study of disabled people's lives and roles in the past. The chapters provide a unique historical insight into the lives of disabled people in Iceland before the term "disability" became a category embedded in law and a target for various interventions by public authorities. However, rather than being a history of disability or disabled people in the traditional sense of "history," the book offers windows into the lives of individuals with different impairments at various times and places in Icelandic history; how they fared, were treated, represented, recorded, and understood. Disabled people have not enjoyed attention in Icelandic historical accounts. In fact, their lives have been hidden and forgotten, overlooked, and ignored. A fate shared with other groups, who were not considered important enough to account for in historical documents. Thus, the research presented here shares the endeavour of many other interdisciplinary fields of study, such as gender studies, queer studies, and various ethnic minority studies, to recover the history of groups previously ignored. In doing so, this volume presents, for the first time, insights into the lives and experiences of disabled people in the past in Iceland and their stories that have not been told before. As it turns out, Iceland is an ideal setting for this kind of historical "excavation" to discover hidden aspects of history and lives not previously accounted for. The country's small population, with its extensive written records and medieval sagas, have been fruitful grounds for the interdisciplinary group of scholars contributing to this volume. Analysing historical data is challenging and the sources of information are often ambiguous, complex, and difficult to interpret. An important aspect of this volume is a much needed and insightful discussion about the methodological challenges and concerns when exploring disability through different sources of historical data. These methodological accounts and reflections on how the contributors employed a variety of methods will be a valuable resource and 


\section{viii Foreword}

guide for future scholars of disability history. Another important aspect of many of the chapters is that although disability is the main focus, the authors have taken an intersectional approach and included additional aspects, such as gender and class, when analysing what impacted the lives and stories of the people presented. Although disability studies are at the centre, this volume is a celebration of collaborative and interdisciplinary endeavour from a range of scholarly disciplines, coming together in furthering our knowledge and understanding of disabled lives. The wide range of disciplines represented allows for the introduction of different disciplinary perspectives, a variety of methodological considerations, and the introduction of different forms of data about disabled people and their lives than is typically encountered in disability studies. Enjoy! 


\section{Acknowledgements}

First and foremost, we would like to acknowledge the financial support of the Icelandic Research Fund (Rannsóknasjóður - Grant number 173655051) for which made the "Disability before Disability" ( $\mathrm{DbD})$ project and this book possible. Second, we would like to thank the contributors for their chapters that comprise this volume, the research was undertaken, and their participation in a number of interesting workshops and meetings.

There are also numerous people whose assistance was critical for the success of this volume. At the University of Iceland, we would like to thank and recognise the institutional support provided to us. In specific, this includes Anna Maria Wojtynska, Project Manager of the DbD project, and Hulda Proppé, Director of research at the School of Social Sciences, both of whom have been with us throughout the duration of the project. We would also like to acknowledge our colleagues at the Centre for Disability Studies, Social Sciences Research Institute, University of Iceland: Rannveig Traustadóttir, Stefán Hardonk, and Snæfríour Póra Egilson. We would also like to thank Elín Valsdóttir for her assistance in manuscript formatting and preparation.

During a DbD workshop in Hvalfjörður, Iceland, in the spring of 2019, we presented an initial outline of this volume to the participants for feedback and comments. This included the strand leaders, strand members, and invited external experts. We would like to thank the external experts in particular for their comments on the book proposal and support at this time and throughout the duration of the project. This includes: Tom Shakespeare (Disability Studies); Irena Metzler (History); David Turner (History); Elaine Gerber (Anthropology); Christina Lee (Viking Studies); as well as Simo Vehmas (Disability Studies).

At Routledge, we would like to thank Mark Sherry, Series Editor of "Interdisciplinary Disability Studies," as well as Claire Jarvis, Senior Editor for Health and Social Care, and Catherine Jones, Editorial Assistant for Health and Social Care. 


\section{List of Contributors}

Arndís Bergsdóttir is a Postdoctoral Fellow of Museology at the University of Iceland. https://orcid.org/0000-0003-1616-4432

Alice Bower is a Doctoral Student in Ethnology and Folklore at the University of Iceland. https://orcid.org/0000-0002-1707-612X

Christopher Crocker is a Postdoctoral Fellow of Medieval Studies at the University of Iceland. https://orcid.org/0000-0002-2523-2313

Eva Pórdís Ebenezersdóttir is a Doctoral Student in Ethnology and Folklore at the University of Iceland. https://orcid.org/0000-0002-4461-5301

Haraldur Thor Hammer Haraldsson is a Doctoral Student in Archaeology at the University of Iceland. https://orcid.org/0000-0002-9827-1217

Ármann Jakobsson is a Professor of Medieval Studies at the University of Iceland. https://orcid.org/0000-0002-4822-1684

Steinunn Kristjánsdóttir is a Professor of Archaeology at the University of Iceland. https://orcid.org/0000-0002-7524-8460

Sigurður Gylfi Magnússon is a Professor of History at the University of Iceland. https://orcid.org/0000-0002-7521-6426

Sólveig Ólafsdóttir is a Doctoral Student in History at the University of Iceland. https://orcid.org/0000-0001-6516-0847

Ólafur Rastrick is an Associate Professor of European Ethnology at the University of Iceland. https://orcid.org/0000-0002-3679-8638

James G. Rice is an Associate Professor of Anthropology at the School of Social Sciences, University of Iceland. He received his doctorate in anthropology from the Memorial University of Newfoundland in 2007. He is currently the Lead Researcher in the project "Disability, immigration, and multigeneration: intersecting factors in child protection cases," funded by the University of Iceland's research fund.

Hanna Björg Sigurjónsdóttir is a Professor of Disability Studies at the School of Social Sciences, University of Iceland. She received her doctorate 
in disability studies from the University of Sheffield in 2005. She is the Principle Investigator for the Disability before Disability project funded by the Icelandic Research Fund.

Guðrún V. Stefánsdóttir is a Professor of Disability Studies at the School of Education, University of Iceland. https://orcid.org/0000-0001-6809-7628

Yoav Tirosh is a Postdoctoral Fellow of Medieval Studies at the University of Iceland. https://orcid.org/0000-0001-7941-7092

Rannveig Traustadóttir is a Professor Emerita and the Director of the Centre for Disability Studies, University of Iceland. https://orcid.org/ 0000-0002-8388-0917

Joe W. Walser III is a Curator of Physical Anthropology at the National Museum of Iceland. https://orcid.org/0000-0001-9329-579X 


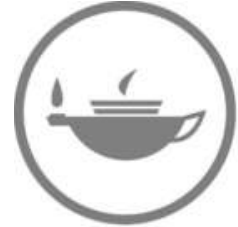

Taylor \& Francis Taylor \& Francis Group

http://taylorandfrancis.com 


\title{
Introduction
}

\author{
Hanna Björg Sigurjónsdóttir and James G. Rice
}

Disability before Disability (DbD) is an interdisciplinary research project about the hidden lives of disabled people in Iceland before the concept of disability existed culturally, socially, and administratively. The project focuses on Iceland from the Age of Settlement, traditionally considered to have taken place from 874 to 930 , until the 1936 Law on Social Security ( $L \ddot{g} g$ um almannatryggingar), which is the first time that disabled people were referenced in Iceland as a legal or administrative category. DbD explored the seldom heard voices from the past by investigating "disability" through a colourful collection of sources available to the project: From the medieval Icelandic prose literature, through to archaeological remains, historical archives, folktales and legends, personal narratives, and museum displays in the contemporary period. A multidisciplinary team of experts working in Iceland in the fields of Disability Studies, History, Archaeology, Medieval Icelandic Literature, Folklore and Ethnology, Anthropology, Museum Studies, and Archival Sciences, along with a collection of post-doctoral and graduate students, provided the data and collaborated in the analysis in a series of meetings and workshops, along with select invited experts from outside of Iceland who shared an interest in the disability field. This volume provides an overview of the output of these collaborative endeavours. The project pursued several questions that were posed to the varied research strands. The overarching question was: What constituted disability in Icelandic society, culture, and history before the establishment of disability as a modern legal, bureaucratic, and administrative concept? This was followed with a series of related questions, inquiring into how disability figured in everyday life, such as: How did disability matter in terms of one's social success? How was disability discussed and narrated? Pursuing these questions led to the collection of a large, and varied, body of data in different forms and from different times periods in Iceland. Interdisciplinary, collaborative analyses at times proved to be fruitful and exciting, and at other times challenging given the significant differences in some source material and time periods. What cemented the project together was the disability studies perspective provided by the project management, and the multidisciplinary input which demonstrated how disability studies could benefit

DOI: $10.4324 / 9781003180180-1$ 
from the knowledge and expertise provided by the diverse disciplines that comprised the research strands of DbD.

The project is grounded in critical disability studies. Disability studies rejects the traditional bio-medical understanding of disability as an individual deficit. Instead, disability is seen as a social phenomenon embedded in social arrangements and cultural conventions. Disability studies offers new avenues of scholarly inquiry whereby the dominant narrative of disability as an individual medical condition or deficit is replaced by an approach that recognises the multifaceted and complex nature of disability as embedded in culture and relations of power. The discipline emerged as a distinct field of research over the last three decades (Davis 2006a, Shakespeare 2014, Söder 2009, Watson et al. 2012). From its origins in the U.K., the Nordic countries, and North America, disability studies has since become global (Connell 2011, Grech and Soldatic 2016, Ingstad and Whyte 1995, 2007, Kakoullis and Johnson 2020), bringing into the fold the varied cross-cultural understandings that, in a way, provided some inspiration for DbD. From its inception, the discipline has been both an academic as well as a political project. Disability studies is rooted in political activism in North America and many European countries during the 1970s and 1980s. This era was marked by political turmoil, protest, and the fight for the civil rights of various social groups. It was in this political atmosphere that disabled people began to coordinate their efforts to fight against oppression, humiliation, discrimination, segregation, and poverty (Oliver 1990, Shapiro 1993, Traustadóttir 2006). Disabled activists protested the power that specialists and professionals wielded over their lives and fought for the right of disabled people to live independently in society, and the discipline of disability studies developed in relation with the everyday lives and political struggles of disabled people (Traustadóttir 2006). One key focus of the early academic work in this field centred on the institutional abuses of people with intellectual disabilities (Biklen and Bogdan 1977, Bogdan and Biklen 1977, Bogdan and Taylor 1976), while another was that of the cultural meaning and experiences of disability through the lens of stigma (Edgerton 1967, Goffman 1961, 1963). This research was very influential and contributed to the deinstitutionalisation movement that gained force in the 1970s and which led to the closing of institutions and the rethinking of how services were designed and implemented.

Disability studies is often presented through a number of approaches or "models." What came to be known as the social model of disability developed out of the pioneering work of activists within UPIAS (Union of Physically Impaired Against Segregation) in the United Kingdom who radically redefined disability by shifting the emphasis from the individual and their impairments to that of society and societal barriers (Barnes 2012). The social model makes clear the distinction between impairment (biological dysfunction) and disability (a process of exclusion) (Barnes 2012, Oliver 1983, 1990). In North America, disability studies was heavily 
influenced by the U.S. civil rights movement and the humanities, placing an emphasis upon concerns with normalcy, ableism, and the role of culture (Davis 2006b, Goodley 2011). The understanding of disability in the Nordic countries is not rooted in self-advocacy and activism as in U.K. and U.S. but arose in conjunction with service providers linked to the Nordic welfare systems. Progressive change was originally focused on the reform of service provision and its effects on the lives of disabled people (Traustadóttir 2004, 2006). The focus of this perspective is on the person-environment interaction and disability is conceptualised and defined as "a mismatch between the person's capabilities and the functional demands in the environment" (Tøssebro and Kittelsaa 2004, p. 22). Disability is therefore not understood as "something caused or created by individual dysfunction or by barriers/oppressive social structures but as the result of a social, linguistic, discursive or cultural construction" and based on the complex interaction between individual and societal factors (Gustavson et al. 2005, p. 32).

In recent years, scholars in disability studies have become unsatisfied with the intellectual limitations of using one model or one approach for understanding the complexities of the disability concept. One response has been to criticise but also draw upon the strengths of these models (Shakespeare 2014, Vehmas and Mäkelä 2008, Vehmas and Watson 2014, 2016), or to refocus efforts on a critique of the larger society in terms of ableism and normalcy and how disability is intimately interwoven with other oppressive forms of power and knowledge such as gender, class, race, and sexuality (McRuer 2006, Mallett et al. 2016). Yet another has been to explicitly push the discipline beyond its original Euro-American framework (Meekosha 2011, Connell 2011, Grech and Soldatic 2016, Kakoullis and Johnson 2020) in order to include perspectives from the global south. A further development has been to emphasise the importance of expanding this multidisciplinary collaboration (Metzler 2006, Shakespeare 2014, Turner 2012, Southwell-Wright 2013). DbD continues this trajectory not only through multidisciplinary collaboration in terms of analysis, but also data sources and collection.

Disability studies, as it emerged in the global north, has had an arguably problematic relationship with history. Given the discipline's activist roots, it followed that the initial focus of scholar-activists would be on the immediate concerns faced by disabled people at the time, such as deinstitutionalisation and independent living. Disability studies scholars were of course aware that disabled people - or at least people with impairments - existed throughout human history and that historically and culturally based narratives play some role in how disabled people in the present are viewed. However, in the early days of the discipline, consumed by the more immediate fights of deinstitutionalisation, accessibility, and human rights, the historical emphasis in terms of understanding disability was not placed too far into the past. Mike Oliver (1990), for example, linked disablement to the capitalist mode of production and the related socio-economic arrangements that produced 
disability. Lennard Davis (2006b) focused on the emergence of the norm and the average, specifically referencing the emerging discipline of statistics and the work of Adolphe Quetelet in the $19^{\text {th }}$ century as playing a key role in how "abnormal" bodies and minds were produced (Davis 2006b, p. 2). Bill Hughes (1999) argues that an understanding of disability, and a critique of the disablist rejection of impaired bodies and people, requires a criticism of modernity itself. What these approaches share is a collective focus on disablement as it emerged in early modern to present day European societies. This is understandable given the orientation of European disability studies at the time, and the situations faced by disabled people they addressed.

But there is also no question that people with impairments have existed throughout the entirety of human history, posing questions as to, among others, how disability was understood in the more distant past and the effects of impairment upon one's social position and status within a given society. Disability studies scholars writing on issues prior the $19^{\text {th }}$ century have produced somewhat mixed efforts, often referencing arguably simplistic or broad generalisations about the positions of disabled people at various points in more distant human history, such as the Middle Ages or the earlier Roman and Greek civilisations. Furthermore, given the extent to which the meaning and definitions of the disability concept are still discussed and debated in the current era, let alone the known problems of contemporary cross-cultural translation (Ingstad and Whyte 1995, 2007, Rice 2020), extending modern European understandings of disability into the more distant past is an exercise fraught with numerous challenges. Yet it is not unusual to find such broad assertions made within disability studies, seeking to posit how ancient societies' understandings of disability/ impairment are linked to contemporary views. For example, Barnes (1997) traces the contemporary negative views of disabled people to the societies of the ancient Greeks and Romans and cites cultural evidence in the form of the arts in support of this argument (Barnes 1997, p. 4-5). The validity of the analysis aside, these declarations emanating from within disability studies are often done by scholars who are not specialists in classical civilisations. Further, such statements are broad and difficult to sustain as they collapse centuries of history and assume a rather monolithic view of Europe in terms of its peoples, cultures and societies and the situations faced by those with impairments in different places and at different periods in time. Such arguments also run the risk of assuming that this data - be it in the form of writings, sculpture, or other forms of art - were perceived the same way as they appear to contemporary sensibilities. This has prompted some scholars with more specialised knowledge to respond. By way of example, Miles (2001) provides a somewhat sarcastic overview of this historical narrative sometimes found within disability studies: a history which starts with the exposure of 'deformed' infants by the ancient Greeks to Martin Luther's advice to drown disabled children before coming to the rise of institutionalisation and the horrors of the Holocaust in modern times. 
The point Miles is making is not to trivialise the sometimes horrific ways in which people with impairments or different bodies were treated, but to argue that this history is complex, and the evidence difficult to find and often ambiguous. What is required is a close collaboration with scholars who are specialists in different disciplines and areas working with different data sources. Looking at the time period of Martin Luther in particular, Miles points out that we not only need to consider the breadth of Luther's writings and theological positions, which are not always consistent, but also the specificity of the socio-cultural context of the $16^{\text {th }}$ century in this part of Europe. Miles's point is that this complexity and ambiguity is often glossed over, and what is offered is more akin to a "caricature" of Luther's writings and the society in which he existed rather than any solid evidence pertaining to the lives and positions of actual people with various impairments at the time.

Some of these deficiencies in the data and the analyses of the lives and living conditions faced by disabled people of the past are some of the challenges that $\mathrm{DbD}$ was designed to engage. In many ways, Iceland is an ideal test case in which to confront these challenges. As a small island nation, existing on the fringes of Europe, Iceland's population in a way is somewhat young, some 30 generations in depth, but with a wealth of written records in the form of the Icelandic Sagas, and later archival records and census data. Iceland was originally inhabited in the $9^{\text {th }}$ century primarily by Norse settlers, as well as via the Viking controlled areas of Ireland and Britain. The landnám (land-taking) generally concluded in the year 930 which corresponds to the establishment of the Alping, the Icelandic general assembly or parliament (Byock 2001, p. 94). Even though the period from 870-1262 was known as the Commonwealth or Free State era, there was no centralized authority or any "state" structure in the modern sense, described as "a loose association of political assemblages, united by law and minimal agreement but without a centralized executive body" (Pálsson 1992, p. 3).

Despite being an island in the North-Atlantic, Iceland remained for much of its history an agrarian society in terms of economic production and social organisation. Towns remained a rarity throughout much of Iceland's history (Karlsson 2000, p. 44), as most of the population lived on coastal farms oriented towards the raising of sheep and cattle, as well as horses used for transportation, and the central highlands were generally uninhabitable (Gunnlaugsson 1988, p. 17). Fishing was a seasonal activity for subsistence, and later trade, but under the direction of farmers who long dominated Icelandic society and politics. As small coastal fishing villages began to emerge, they posed a threat to the labour supply needed on the farms. In order to protect the agricultural mode of production, those who were not engaged in farming had to enter into annual labour contracts as farmhands (Durrenberger and Pálsson 1989, p. 4, Karlsson 2000, p. 109). Up until the late 19th century, laws were passed in the interest of the landed farming class to prevent settlement on the coast. This was done in order 
to protect the agricultural labour supply, as well as to prevent dependency on poor relief as fishing was not seen at the time as a stable occupation (Durrenberger 1997, p. 78). Another effect these laws had though was also to stall the process of urbanisation (see Chapter 8 this volume).

Iceland gained its independence from Denmark in 1944, but still retained much of its rural orientation and generally lacked comparable institutions and social programmes aimed at vulnerable populations as found in mainland Europe. Elderly and disabled people, as well as poor and destitute, throughout most of Iceland's history were the responsibility of the household. In the event of the failure of a farm, or the inability to locate responsible kin, the hreppur, or local administrative unit, became the responsible party (Gunnlaugsson 1988, p. 53). The organisation of poor relief in Iceland has a long and durable history; it was codified in the Grágás, a law code from the early $12^{\text {th }}$ century, but some elements of which have even earlier roots, for example with regard to the tithe law of 1096 which held that one quarter of the tithe collected from tax paying farmers had to be forfeited to the hreppur for the administration of poor relief (Gunnlaugsson 1988, p. 93).

Paupers - a mix of orphans, elderly people, disabled people, and those who could not, or would not, contribute their labour on the farm - were met with varying degrees of hostility and suspicion that would become sharpened during the times of economic hardships that were common throughout Icelandic history. Increasing numbers of paupers were a particular cause for concern, to the point where they were perceived as a threat to the very social order (Karlsson 2000, p. 252). Poverty, dependency on poor relief and suspicions of malingering extended in various ways into contemporary Iceland. As the historian Gísli Ágúst Gunnlaugsson notes, it was not until 1917 that prohibition on the right of paupers and those on poor relief to marry was lifted (Gunnlaugsson 1988, p. 94). Disability in Iceland was, and arguably still is in certain ways, partly intertwined with perceptions of social and economic marginalisation, dependency, stigma, and suspicion which appears to owe something to this history. In contemporary Icelandic society, fears about increasing numbers of öryrkjar, or disability pensioners, appear with a certain regularity in the Icelandic media and political discourses, linked to the belief that disabled people are dependent and not economically productive (Rice, 2012, Rice and Traustadóttir, 2011).

However, these broad statements do not capture well the contradictions, ambiguities, and nuances of disability from the perspective of lives-as-lived. One goal of the DbD project was to bring some of the stories of disabled people in Iceland to life, in some cases attempting to reconstruct lives from the distant past based upon only physical remains (see Chapters 2 and 10 in this volume); Using diaries and archival documents to produce microhistorical accounts of individuals (see Chapters 3-5 and 8 in this volume); Delving into museum displays for evidence (or not) of disabled people in the past (see Chapter 6 in this volume); And using literary sources to see 
how disability was discursively produced in different times and in different sources (see Chapters 1, 7, and 9 in the volume). The project has found that there certainly was evidence of exclusion and harsh treatment, but there was also evidence of disabled people who were valued members of their society - and who were noted because of their impairment as well as their achievements, but also instances where their impairments were seen as only a minor part of the individual.

Each strand of the Disability before Disability project was led by a leading scholar in the respective fields, along with a team of post-doctoral scholars and graduate students, drawing upon the tools and traditions of each discipline but with the collective goal of understanding disability before disability. The edited volume that we are introducing here places an emphasis upon the contributions of these various strands. Some of the contributions represent the work of a sole author within his or her strand, reflecting on what their expertise and that of their discipline offers to a study of disability before disability, or else incorporating a disability studies approach upon the kinds of data they normally work with. An example of the former is Sigurður Gylfi Magnússon's One Story, One Person - The Importance of Micro/Bio Research for Disability Studies, which introduces microhistory and the value of researching individual lives. This work also serves as a preface to help contextualise the collaborative contribution by Guðrún Valgerður Stefánsdóttir (disability studies) and Sólveig Ólafsdóttir (history) in The Peculiar Attitude of the People - The life and social conditions of one "feebleminded" girl in the early 20th century - the analysis of an autobiography of a woman born in north Iceland in 1927 who was labelled 'feebleminded.' Writing from the perspective of Folklore but engaged with scholars working within the geography of disability, Ólafur Rastrick's Physical Impairment and The Spatial Dimensions of Everyday Life in Rural Households in Pre-Industrial Iceland addresses how design and layout of dwellings and home environment affected the quality of life of physically impaired individuals in preindustrial Iceland. Working at the other end of the historical spectrum, and from the perspective of archaeology, Haraldur Pór Hammer Haraldsson's Fictive Osteobiographical Narrative - The Missing Puzzle Pieces presents what he calls a 'fictive osteobiographical narrative' in order to analyse the excavated human remains of a man thought to have lived between 1000-1104. Arndís Bergsdóttir, working within the discipline of Museum Studies, in Dis-labling Absence Absencepresence as Matters that Matter, investigates the traces of disability in Icelandic museum collections through the cataloguing system to pose questions about presence and interpretation of histories and narratives of disability.

Other chapters within this volume represent collaborations between scholars working within their respective disciplines. Christopher Crocker, Yoav Tirosh, and Ármann Jakobsson, writing from the perspective of Medieval Icelandic literature, review some key methodological concerns 
scholars must account for when exploring disability in the context of medieval Icelandic saga writing. In Disability in Medieval Iceland: Some Methodological Concerns they note some of these challenges but also point toward the more fruitful approaches scholars of the medieval sagas can take to gain a better understanding of how physical, mental, and sensory differences were experienced, communicated, represented, and interpreted in medieval Iceland. In Beneath the surface: Disability in Archeological and Osteobiographical Contexts, Steinunn Kristjánsdóttir and Joe W. Walser III discuss disability from a post-human angle in an archaeological and osteological context. Their work draws upon case studies of skeletonised individuals from a monastic site in East Iceland (1494-1554) to identify bodily impairments from skeletal remains to make inferences about how these individuals may have adapted to the biological limitations and potentially subsequent social marginalisation they may have experienced. Alice Bower, writing from the perspective of Folklore in Guðmundur Bergpórsson as Creator and Creation: A Folk Narrative Study of a 17th Century Disabled Poet, seeks to shine light upon the life and literary works of one of Iceland's noted poets. Guðmundur's impairments were well known and have become the most prominent theme of legends about him collected by folklorists during the $19^{\text {th }}$ and $20^{\text {th }}$ centuries. Finally, writing from Medieval Icelandic literature, Christopher Crocker and Yoav Tirosh explore issues of health, illness, and healing in medieval Iceland, in particular dealing with the corpus of texts known as the Íslendingasögur (Sagas of Early Icelanders). In Health, Healing, and the Social Body in Medieval Iceland they adopt a disability studies approach and seek to understand the lives and representations of those in the sagas who have sustained injuries, illnesses, and disease.

All of the chapters are interdisciplinary in that the authors engage with a disability studies perspective while applying their own disciplinary expertise and specialist knowledge. Some of the chapters, however, extend this further to produce collaborative work of two scholars from different disciplines. Guðrún Valgerður Stefánsdóttir (disability studies) and Sólveig Ólafsdóttir (history) analyse together the autobiographical writings of Bjargey Kristjánsdóttir (nicknamed Bíbí) a woman with intellectual disabilities who grew up on a farm in North Iceland in the early $20^{\text {th }}$ century. Bíbí wrote her autobiography in secret from her family and neighbours and very few of them even knew that she could read and write. Bíbi writes about her family and neighbours with a great sense of humour and irony within a socio-cultural and historical context in which it was seen as a great shame for parents to have a child with disabilities. Finally, Eva Pórdís Ebenezersdóttir (Folklore) and Sólveig Ólafsdóttir (History) consider the case of Sigríður Benediktsdóttir (known as Stutta-Sigga) who was a child minder and storyteller (1815-1900) with physical as well as cognitive or mental differences. Through analysing her "life-threads," tracing Sigríður through various public sources, from birth to death, the findings are then compared to the narratives that have been preserved both during her lifetime and after 
her death. The goal is to illuminate the life of Sigríður not as a subject of research but as an individual who acts, in a way, as a co-worker contributing to the research with her life stories. All of the contributions present partial, and often fractured and incomplete, pictures of disability before disability. However, the goal was not to produce a comprehensive story of the history of disability in Iceland but to demonstrate what can be done through a collaboration with different disciplines using different sources of data and to open a door upon an often overlooked history and to encourage more work to be done, either in Iceland or beyond.

\section{References}

Barnes, C., 1997. A legacy of oppression: A history of disability in western culture. In: L. Barton and M. Oliver, eds. Disability studies: Past, present and future. Leeds, UK: The Disability Press, 3-24.

Barnes, C., 2012. Understanding the social model of disability. In: N. Watson, A. Roulstone, and C. Thomas, eds. Routledge handbook of disability studies. New York: Routledge, 12-29.

Biklen D., and Bogdan R., 1977. Media portrayals of disabled people: A study in stereotypes. Interracial Books for Children Bulletin, 8, 4-9.

Bogdan, R., and Biklen, D., 1977. Handicapism. Social Policy, 7 (5), 14-9.

Bogdan, R., and Taylor S. J., 1976. The judged, not the judges: An insider's view of mental retardation. American Psychologist, 31, 447-452.

Byock, J., 2001. Viking Age Iceland. London: Penguin Books.

Connell, R., 2011. Southern bodies and disability: Re-thinking concepts. Third World Quarterly, 32 (8), 1369-1381.

Davis, L., ed., 2006a. The disability studies reader. 2nd edition. New York: Routledge.

Davis, L., 2006b. Constructing normalcy: The bell curve, the novel, and the invention of the disabled body in the nineteenth century. In: The disability studies reader: Second edition. New York: Routledge, 3-16.

Durrenberger, P. E., 1997. A local elite and underdevelopment in a peripheral economy: Iceland in the 18th-20th centuries. In: R. E. Blanton, P. N. Peregrine, D. Winslow, and T. D. Hall, eds. Economic analysis beyond the local system: Monographs in economic anthropology, no. 13. Lanham, MD: University Press of America, 71-83.

Durrenberger, P. E., and Pálsson, P., 1989. Forms of production and fishing expertise. In: P. E. Durrenberger and G. Pálsson, eds. The anthropology of Iceland. Iowa City: University of Iowa Press, 3-18.

Edgerton, R., 1967. The cloak of competence: Stigma in the lives of the mentally retarded. Berkeley: University of California Press.

Goffman, E., 1961. Asylums: Essays on the social situation of mental patients and other inmates. New York: Penguin.

Goffman, E., 1963. Stigma: Notes on the management of spoiled identity. London: Penguin.

Goodley, D., 2011. Disability studies: An interdisciplinary introduction. London: Sage.

Grech, S., and Soldatic, K., eds., 2016. Disability in the global south: The critical handbook. Cham, NY: Springer. 
Gunnlaugsson, G. Á., 1988. Family and household in Iceland 1801-1930: Studies in the relationship between demographic and socio-economic development, social legislation and family and household structure. Thesis (PhD). Uppsala University.

Gustavsson, A., Tøssebro, J. and Traustadóttir, R., 2005. Introduction: Approaches and perspectives in Nordic disability research. In: A. Gustavsson, J. Sandvin, R. Traustadóttir and J. Tøssebro, eds. Resistance, reflection and change: Nordic disability research. Lund, SE: Studentlitteratur, 23-44.

Hughes, B., 1999. The constitution of impairment: Modernity and the aesthetic of oppression. Disability \& Society, 14 (2), 155-172.

Ingstad, B., and Whyte, S. R., eds., 1995. Disability and culture. Berkeley: University of California Press.

Ingstad, B., and Whyte, S. R., eds., 2007. Disability in local and global worlds. Berkeley: University of California Press.

Kakoullis, E. J., and Johnson, K. eds., 2020. Recognising human rights in different cultural contexts: The United Nations convention on the rights of persons with disabilities (CRPD). Singapore: Palgrave Macmillan.

Karlsson, G., 2000. The history of Iceland. Minneapolis: University of Minnesota Press.

Lög um almannatryggingar (Law on Social Security) 1936. Alpingi (Icelandic Parliament).

Mallett, R., Ogden, C. A., and Slater, J., 2016. Theorising normalcy and the mundane: Precarious positions. Chester, UK: University of Chester Press.

McRuer, R., 2006. Crip theory: Cultural signs of queerness and disability. New York: NYU Press.

Meekosha, H., 2011. Decolonising disability: Thinking and acting globally. Disability \& Society, 26 (6), 667-682.

Metzler, I., 2006. Disability in medieval Europe: Thinking about physical impairment during the high Middle Ages, c.1100-1400. New York: Routledge.

Miles, M., 2001. Martin Luther and childhood disability in 16th century Germany: What did he write? What did he say?. Journal of Religion, Disability \& Health, 5 (4), 5-36.

Oliver, M., 1983. Social work with disabled people. Basingstoke, UK: Macmillan.

Oliver, M., 1990. The politics of disablement. London: Macmillan.

Pálsson, G., 1992. Introduction: Text, life, and saga. In: G. Pálsson, ed. From sagas to society: Comparative approaches to early Iceland. Middlesex, UK: Hisarlik Press, 1-25.

Rice, J. G., 2020. Anthropology, disability and the CRPD. In: E. J. Kakoullis and K. Johnson, eds. Recognising human rights in different cultural contexts: The United Nations convention on the rights of persons with disabilities (CRPD). Singapore: Palgrave Macmillan, 45-62.

Rice, J. G., 2012. "I'm not enough of a loser": A crip interpretation of disability and charity in Iceland. lambda Nordica, 17 (1-2), 121-143.

Rice, J. G., and Traustadóttir, T., 2011. Fátækt, fötlun og velferð [Poverty, disability and welfare]. Stjórnmál \& Stjórnsýsla, 2 (7), 381-398.

Shakespeare, T., 2014. Disability rights and wrongs revisited: Second edition. London: Routledge.

Shapiro, J., 1994. No pity: People with disabilities forging a new civil rights movement. New York: Three Rivers. 
Söder, M., 2009. Tensions, perspectives and themes in disability studies. Scandinavian Journal of Disability Research, 11 (2), 67-81.

Southwell-Wright, W., 2013. Past perspectives: What can archaeology offer disability studies? In: M. Wappett and K. Arndt, eds. Emerging perspectives on disability studies. New York: Palgrave Macmillan, 67-95.

Tøssebro, J., and Kittelsaa, A., 2004. Studying the living conditions of disabled people: Approaches and problems. In: J. Tøssebro and A. Kittelsaa, eds. Exploring the living conditions of disabled people. Lund, SE: Studentlitteratur, $17-43$.

Traustadóttir, R., 2004. Fötlunarfræði: Upphaf, próun og fræðileg sjónarhorn. In: Ú. Hauksson, ed. Rannsóknir i félagsvísindum V: Félagsvísindadeild. Reykjavík: Háskólaútgáfan, 519-530.

Traustadóttir, R., ed., 2006. Fötlun: hugmyndir og aðferðir á nýju fraðasviði. Reykjavík: Háskólaútgáfan.

Turner, D. M., 2012. Disability in eighteenth-century England: Imagining physical impairment. New York: Routledge.

Vehmas, S., and Mäkelä, P., 2008. A realist account of the ontology of impairment. Journal of Medical Ethics 34 (2), 93-95.

Vehmas. S., and Watson, N., 2014. Moral wrongs, disadvantages, and disability: A critique of critical disability studies. Disability \& Society, 29 (4), 638-650, DOI: 10.1080/09687599.2013.831751

Vehmas. S., and Watson, N., 2016. Exploring normativity in disability studies. Disability \& Society, 31 (1) 1-16, DOI: 10.1080/09687599.2015.1120657

Watson, N., Roulstone, A., and Thomas, C., eds. 2012. Routledge handbook of disability studies. New York: Routledge. 


\title{
1 Disability in Medieval Iceland Some methodological concerns
}

\author{
Christopher Crocker, Yoav Tirosh, \\ and Ármann Jakobsson
}

\section{Introduction}

Medieval medicine, including its documented practices, theoretical underpinnings, and varied traditions, has long sparked interest among scholars. However, in recent decades, the complexities of how physical, mental, and sensory differences were variously experienced, communicated, represented, and interpreted during the Middle Ages has garnered considerable attention. This more nuanced approach accompanied greater interest in medieval perceptions of the body and was informed by the adoption of a disability studies perspective fundamentally challenging the idea that embodied differences must be viewed through a predominantly or even strictly biomedical lens informed by both medieval and modern scientific knowledge. At the same time, the notion that - failing successful medical intervention - cruelty and severe social exclusion were inevitable responses to such phenomena is no longer taken for granted (Metzler 2006, 2013, Eyler 2010, Nolte et al. 2017, Hsy et al. 2020). Applying a disability studies approach emphasises the diversity of attitudes toward physical, mental, and sensory differences present during the Middle Ages including tolerance, sympathy, and empowering viewpoints. Simultaneously, it challenges one of the more pervasive ways the modern period has sought to distinguish and elevate itself above the supposed ignorant, cruel, and miserable medieval past of the popular imagination.

Following this trend, scholars of medieval an Icelandic culture and society have also shown increasing curiosity in exploring how medieval Icelanders experienced, communicated, represented, and interpreted embodied differences of a physical, mental, or sensory nature more than simply biomedical phenomena; that is, as an individual deficit requiring some kind of medical intervention and to which modern scholars can apply their own retrospective diagnosis. Following important pioneering efforts in the late 1990s and early 2000s, predominantly found in the work of Edna Edith Sayers, published as Bragg (1994, 1997, 2004a, 2004b), Brynhildsvoll (1993), Overing (1999), and Lassen (2003), recent years have seen growing interest in exploring what Sexton (2010) has referred to as the "rich cultural response to the 
premise of disability" in medieval Icelandic society (p. 163). Thus, a subfield of medieval Icelandic disability studies has gradually begun to emerge. As elsewhere during the Middle Ages and still today, accounting for things like fear, cruelty, and social exclusion as well as tolerance, sympathy, and empowerment all play a vital role in gaining an understanding of disability in the context of medieval Iceland.

Reviewing and building upon recent scholarship on the topic, the present chapter explores some of the key issues scholars face when investigating disability in the context of the medieval Icelandic sagas. These include the nature of the sources, the terms they use to refer to physical, mental, and sensory differences, and the complicated relationship between texts and the culture they hail from. All these issues are also present in the other studies in this book but are explored here from a medieval standpoint.

\section{Narrative sources}

Among the abundance of surviving written material produced by Iceland's relatively late-coming medieval literary culture, the so-called Íslendingasögur (Sagas about Early Icelanders) have frequently attracted the most scholarly attention with respect to disability (Jakobsson et al. 2020 , p. 443, Crocker 2019, p. 40-41). Though these sagas likely derive from enduring cultural memories and oral traditions, saga writing in Iceland probably did not begin until the late 12th century. Primarily focusing on events taking place in or in connection with Iceland during the so-called "Saga Age," the 9th, 10th, and early 11th centuries, but only extant in a handful of fragments from the 13th century and manuscripts from the 14th and 15 th centuries, or even later, the issue of their source value is both important and intricate to consider. Issues of dating and consequently questions of whether these sagas reflect the period they purport to represent, that of the time of their writing or preservation, or perhaps all three to varying degrees, lie at the core of any investigation of how they might reflect the dominant social structures of medieval Icelandic society and the prevailing ideologies and mentalities informing them.

The Íslendingasögur are undoubtedly the historical writing of their time, but they are clearly also infused by a narrative tradition with a strong focus on entertainment and with an aesthetic purpose. While far removed from the events depicted, they nevertheless are an attempt to portray an older age. Whether the sagas should be viewed as historical, fictional, or some combination of the two, they are first and foremost narratives. Even if a given saga succeeds, to some degree, in correctly describing the social reality it purports to represent, it also inevitably constitutes an interpretation of that same reality (Meulengracht-Sørensen 1992, p. 28). Thus, despite the "reality effect" a saga narrative might engender among its audience, the past lived reality itself cannot be assembled from such a source in a credible and comprehensive way (Jakobsson 2015, Jørgensen 1990, Barthes 1986). Yet, as 
suggested above, this does not mean that the source value of the sagas with respect to the past should be dismissed outright, including, for example, the insight they can provide concerning certain prevailing ideologies and mentalities as reflected in the ways physical, mental, and sensory differences were experienced, communicated, represented, and interpreted in medieval Iceland. In addition, it must also be kept in mind that it is through language and discursive representation that scholars gain access to such insights as they become manifest in medieval saga writing (Rikhardsdottir 2017, p. 87-88). Being aware of these matters may seem obvious but maintaining such an awareness is particularly crucial in order to avoid projecting our own contemporary assumptions about disability onto the past.

One purpose of a historical narrative, indeed all narrative, is to construct an identity, be it personal or social (Erlingsson 1992), and the sagas are no exception in that they function as "identity machines" (Cohen 2003). As such, it is no wonder that they have been increasingly mined as social narratives that reflect attitudes toward things like class, age, and gender and, in a similar fashion, can also be mined as sources reflecting medieval attitudes and experiences relating to disability. With some notable exceptions (Bragg 1994, 1997, Wäckerlin 2006, Jakobsson 2014b, Künzler 2016, p. 259-265, p. 313-322, Wilson 2016, Lawing 2016, 2021, Crocker and Jakobsson 2021, Tirosh 2020), relatively few scholars have sought to explore sagas outside of the corpus of the so-called Íslendingasögur using a disability studies lens. These include hagiographic narratives, romances, legendary tales of the ancient past, stories of Norwegian kings, and historical texts concerned with Iceland's so-called "Sturlung Age" from the early twelfth to the mid-thirteenth century. Saga narratives assigned to these categories, like those designated as Íslendingasögur, present corresponding issues concerning their respective source value. Yet, they are no less valuable in reflecting medieval Iceland's dominant social structures and its prevailing ideologies and mentalities. In fact, continuing to attend to a wider assortment of medieval sagas beyond the commonly studied Íslendingasögur will doubtlessly help to provide a more complete picture of how physical, mental, and sensory differences were experienced, communicated, represented, and interpreted in medieval Iceland.

\section{Terminology}

One of the fundamental fallacies facing disability scholars working with the past is the teleological notion that disability in its present form always existed waiting for the present to address it properly and that it is entirely independent of the present ideas and forms of disability. Another is the notion that scholars can seek out the past vocabulary of disability as if it is scientific, clearly defined by all who use it who more or less do so in the same way. Indeed, a neat consonance between vocabulary and taxonomy is often assumed. Neither idea is true: pre-modern words are as a rule not concepts 
and the absence of the later social structures of disability in the past may mean that physical, mental, and sensory differences must be addressed from a totally new standpoint. However, closely examining medieval vocabulary referring to such differences is essential and can provide an indication of how the discourse of embodied differences during that age was embedded within language and terminology.

The Modern Icelandic technical term corresponding to the adjective "disabled" is fatlaður, a word that is first attested in the 19th century. First, it is just a word that emerges as an analogy (literally it means "hand in a sling") but with the advent of formal institutions of disability in the early 20th century it gradually became a technical term used in public records, such as Hagskýrslur Íslands, where it is translated into French as anormaux (abnormal). The term embraced a variety of physical, mental, and sensory differences of varying degrees and was also used as a way of putting disparate groups under one hat. In medieval Icelandic, there is no equivalent unifying word for various disabilities. In the late 15th century, a character in the legendary Bósa saga ok Herrauðs is described as "hnýtt ok bömluð" (crooked and bent) (Jiriczek 1893, p. 5), which is the only known attestation of the term bamlaðr (bent), whereas hnyttrlknytttr (crooked) is a more frequent word, which was sometimes used for the 12th century King Ingi "the Hunchback" (Aðalbjarnarson 1941-51 p. 331). These words do not seem to refer to any specific kind of disability but rather to various forms of bodily difference. The term lama, cognate to the term "lame," is more common and also has a more general meaning as it is occasionally used as a synonym for the term vanmegna (powerless) (Unger 1874, p. 330).

Another word that appears in many hagiographic narratives and romances is krypplingr (occasionally kryppill, kroppinbakr, or even kryppubakr), which is usually glossed as "hunchback" and often seems to refer to precisely that condition. In some instances, however, it is probably a substitute for bamlaðr or knýttr, such as when used as a nickname for the aforementioned King Ingi (Unger \& Vigfússon 1868, p. 513-516), and thus was possibly sometimes used as a general word for disabled people. Much like its modern English cognate "cripple," the term can be used in a derogatory way. For example, in Hectors saga, a late medieval romance narrative, the phrase "hverium porpara edur kryplinngi" (every scoundrel or cripple) appears in the beginning of a duel when the hero is chiding his opponent (Loth 1962, p. 155). Yet, the word is still mostly neutral, not seeming to impart any negative value upon those it is used to describe, and usually appears in miracle narratives, such as when the Virgin Mary appears before a krypplingr and heals him (Unger 1871, p. 688).

Most of the other words for disabilities refer to specific conditions but are usually more common, reflecting a tendency to focus on the singularity of each physical, mental, and sensory difference rather than to generalise about disability. Haltr is one of the most common of these terms, referring to people who limp, which appears in a variety of medieval Icelandic 
narratives, mostly in miracle stories. The same goes for terms commonly associated with sensory impairments, such as daufr (deaf), dumbr (speechless), and blindr (blind), which are also most common in hagiographic literature, for example, when dealing with the miracles of the Christ. Three of these words, halti, blindi, and daufi, are also commonly used nicknames, which characterised the culture of the period and appear across all kinds of saga writing. Such nicknames are very often associated with physical features (Jónsson 1907, p. 161-381, Whaley 1993, p. 122-146, Willson 2008, p. 487-493, Sexton 2010) that are supposedly unusual. People are called, for example, breiðhöfði (broadhead), ballhöfuð (roundhead), klakkhöfði (pointyhead), langhöf $\partial i$ (longhead), loðinhöfði (hairyhead), hrafnhaus (ravenhead), svinhöfði (pighead), and hesthöfði (horsehead). All these nicknames demonstrate an interest in minute physical differences that would mostly be seen as insignificant today, and they are also indicative of a tendency to reduce people to specific bodily features. The nicknames listed above are not necessarily derogatory, apart from possibly svínhöf $\partial i$ and hesthöf $\partial i$, which indicate that the person in question was thought to resemble a pig or a horse. None of these people would necessarily be disabled as the concept is defined in modern parlance (Cock and Skinner 2019). On the contrary, the tendency to look closely at any bodily feature might end up in more or less everyone being identified by supposedly abnormal physical characteristics.

When it comes to intellectual impairments, these are most often presented as temporary in medieval saga narratives. There are miracle stories where people with apparent mental illnesses are cured by the interference of the saint, such as when Saint Porlákr cures a man who tried to commit suicide when in the throes of a bout of hugarválad (melancholy) but promptly repented (Egilsdóttir 2002, p. 264). And there are also the well-known kolbitar narratives in which an unpromising youngster eventually finds his way and becomes a hero. These "ashlads," who are named such due to a tendency to laze around close to the fire, are often referred to as afglapi, fifl, glópr, or fóli by others but then go on to prove them wrong (Egilsdóttir 2005, Michelson-Ambelang 2015, p. 113-114, 151-53, Higman 2021). The narrator of a given saga will often distance themselves from such disparaging terms, which are essentially erroneous interpretations of the real powers of the unpromising youngster. This does not necessarily indicate that the society in which the sagas are composed does not believe that there are such things as afglapar and fifl but that most narratives where the words are used do not provide a good indication of how people would really fit into these categories. A further case that is interesting is that of Melkorka in Laxdoela saga who pretends to have lost the power of speech and yet people feel they can see that "hon var engi afglapi" (she was no fool) (Sveinsson 1934, p. 27). Essentially, Melkorka is much like the kolbitar in that she is not really an afglapi, but what is noteworthy is that her silence could evidently be interpreted as a sign of intellectual impairment. Later, of course, it turns out that 
she has only been pretending but the episode indicates that an inability to speak could be seen as a sign of intellectual impairment.

Finally, the only case of a figure labelled an afglapi (idiot) that is not dealt with in the sagas as a simple case of misunderstanding is Helgi Ingjaldsson, a minor supporting character in Gisla saga. He is introduced as "afglapi sem mestr mátti vera ok fiff" (the greatest idiot there could be and a fool) and it is revealed that during the day he is tied to a stone and eats grass (Pórólfsson \& Jónsson 1943, p. 79). Scorn is heaped on this sad boy throughout the narrative, in which he serves the function of "comic relief," since the outlaw Gísli Súrsson imitates him in order to escape from his pursuers. Thus, the case of Helgi is a sad reminder that those like him were trapped in a social hierarchy in which they were seen as so inferior as to border on the bestial (Michelson-Ambelang 2015, p. 132-133, Jakobsson et al. 2020, p. 444-451, Higman 2021, p. 80-83). The description of Helgi is not precise but it is clear that he was unable to communicate. This means that the words afglapi and fif $f$ can be used about him without the narrator stepping in and proving his detractors wrong, as they do in most other cases where these terms are bandied about.

What insights are then to be drawn from medieval disability terminology in general? It seems to be mostly functional when used in hagiographic narratives describing the healing powers of Christ and the saints of the Catholic church, including the Icelandic saints Porlákr, Jón, and Guðmundr. The idea of a broad group of disabled people is rarely seen in Icelandic medieval narratives and it is also somewhat clear that a multitude of modern disabilities would not have been included in such a category. However, instances like Helgi Ingjaldsson's also prove that there are cases that are thought to warrant terms - such as afglapi, fifl, glópr, or fóli - that can also be used to mock others who eventually prove themselves not to fit into these categories.

\section{The issue of ability}

The attitudes reflected toward people with physical, mental, and sensory differences in the sagas correlate well with the language used to describe them. Their treatment reveals itself in a wide array of intersectional considerations that cannot be easily pinned down in a catch-all phrase or general rule of thumb. The intricacies of transmission and relationship with history discussed above also means that it is sometimes difficult to ascertain if the scenes portrayed reflect lived experiences or literary convention; but they are nevertheless revealing in terms of social attitudes and norms, and even the most fanciful of scenes reveal possibilities of using, discussing, and negotiating embodied difference in medieval Iceland. This complexity is evident in the different opportunities awarded disabled people: while some are denied agency in their own lives, some are able to function independently or to receive assistance that allows 
their will to be done. As Ronen (2018) points out, "at the basis of questions of agency is control of one's own body" (p. 19). She has demonstrated that in the case of Old English miracles, different impairments were not seen as disabling as such. In the vast Old Norse literary world, a complex picture arises, based on generic convention (Ronen 2018, p. 25-26) as well as authorial sentiment.

In medieval saga writing, for example, as in other medieval cultures (Tovey 2010, Turner 2010, Laes 2019), when a Norwegian king's ability to govern is hampered by disability, his hirðmenn (courtiers) scramble to either allow for his return to his former abilities, or alternatively to accommodate him in his new bodily circumstances. In both Ágrip af Noregskonunga sögum and Heimskringla, when king Haraldr's Sámi wife Snæfríðr dies the Norwegian sovereign continues to sit over her seemingly untarnished body for three years. His counsellor Porleifr spaki (the wise) treats king Haraldr's abnormal grief by moving Snæfríðr's body and thus exposing her true state of decay (Einarsson 1985, p. 5-6, Aðalbjarnarson 1941-51, p. 126-127, Teichert 2016). In Heimskringla, and even more prominently in Morkinskinna, when king Sigurðr Jórsalafari (the Pilgrim/Crusader) begins to exhibit signs of deteriorating mental health that cloud his judgement and cause him to make violent and/or unchristian choices, his courtiers similarly make efforts to temper his rage. In one case, an Icelander named Óttarr birtingr (trout) reproaches the king and stops him from hitting his wife and attempting to burn a precious book, while in another, a man named Erlendur (or Sigurður Sigurðarson) stops the king from drowning a man (Jakobsson and Guðjónsson 2011, p. 140-142, Aðalbjarnarson 1941-51, p. 269-270, Jakobsson 2014b, Crocker and Jakobsson 2021).

In terms of non-congenital differences, injuries in battle may create a complex situation; while they embody the battle experience of a seasoned warrior and often do not prevent the warrior from continued fighting, they can also embody un-wholeness, in the eyes of society as well as the injured person themselves. In the case of Grettis saga's Qnundr tréfótr (tree-foot), a warring Viking who has lost his leg in battle against King Haraldr hárfagri continuously displays battle prowess yet shows himself to be mentally affected by his physical circumstances, as well as with a slightly diminished status as an eligible bachelor (Jónsson 1936, p. 3-25, Sexton 2010, p. 151-157, Evans 2019, p. 87-92, Bragg 2004a, p. 240-245). But the battle injury that irks Qnundr also supplements his propensity for ingenuity in battle. In a key battle against Viking marauders, Qnundr thins out enemy forces by devising a trap. Later, when he engages in face-to-face battle with these enemies, who had previously mocked his wooden leg, the leader's axe is stuck in Qnundr's leg support, stalling him from battle and allowing Qnundr to deliver a blow that struck off his hand (Jónsson 1936, p. 10-12). Thus, the very thing that marks Qnundr as different is that which gives him an edge in battle. In other cases, what could be considered disabilities in modern times were in fact used in narratives as a strategic advantage in battle. 
In Ragnars saga loðbrókar, which takes place in the legendary times but concerns individuals that Icelanders would often trace their lineage to, Viking leader Ragnarr has a son dubbed Ívarr hinn beinlausi (the bone-less) due to a condition of his lower body where "brjósk væri par, sem bein skyldu vera" (there was cartilage where bone should be) (Olsen 1906-08, p. 129). Ívarr is described as the wisest of Ragnarr's sons and has attendants carry him around. In one key scene, Ívarr uses his perceived disability to his and his brothers' advantage when the cow-god Síbilja is pitted against them by King Eysteinn of Sweden. Ívarr's men catapult him at Síbilja, and he kills her upon impact, without himself being injured, thus weaponising his body and accomplishing a feat unachievable by someone who we might describe as able-bodied. In the romance Sigrgarðs saga frakna a character named Höror uses his hunched-back as a devastating weapon. It is, however, later disclosed that Hörðr's hunched-back is, in fact, bags of iron hidden beneath a dwarfish-constructed jerkin (Hall et al. 2013). This revelation notwithstanding, this example similarly shows that there was room in the imaginations of medieval Icelanders for creative utilisation of impairments in battle.

Another narrative theme occurs when patriarchs continue to maintain their households despite what might be considered disabling circumstances. One such head of household is Porsteinn hviti (the White) from Sunnudalr in the Northeast of Iceland, who continues to attend to his duties following the sudden onset of blindness. His continued leadership is, however, contingent on the support of those around him, namely, his son Porgils and later the brother of his son's killers, who each assist him in maintaining his farmstead (Jóhannesson 1950). Hlenni inn gamli (the Old) of Eyjafjarðardalr is another example of a blind Northern leader who controls his own household and even fosters the son of local magnate Guðmundr inn riki (the powerful) (Porláksson 1880, p. 200). Hlenni's character is further enriched with a stern sense of honour and a biting sense of humour (Tirosh 2019, p. 143-145). It is important to note, however, that Porsteinn's blindness is non-congenital, and it is possible that Hlenni's was not either; a person born with blindness would perhaps face greater difficulties acquiring success and status in this society than someone who became visually impaired later in life (Crocker 2020).

Access to agency and status may be achieved by kings and Vikings with disabilities, but from an intersectional perspective it is frequently not within the reach of women, whose perhaps limited agency is further diminished. In Eyrbyggja saga, for example, once Auður's hand gets hacked off by an enemy of her husband Pórarinn, her body becomes an affront to her husband that requires vengeance while Auður herself loses her voice in the text; once her injury is sufficiently paid for with blood, Pórarinn leaves Iceland without a word on Auður's fate (Sveinsson 1935, p. 33-60, Heiniger 2020, Lawing 2014). As mentioned above, Laxdala saga describes the non-speaking and presumed non-hearing enslaved woman Melkorka, who receives little respect in her household. When it is revealed that she can, in 
fact, speak and hear, her status rises; that the text reveals that she is an Irish princess shows that class and disability are considerations that go hand in hand (Bragg 2004b, Künzler 2016, p. 113-117; Wolf 2018, Tirosh 2020).

Age also comes into play in terms of disability. Metzler asserts that "old age of itself is not a disabling condition during the Middle Ages; instead, the individual physical or mental condition that characterised a person was the defining factor" (Metzler 2013, p. 153). This is further complicated by the fact that while some men like Porsteinn hvíti and Hlenni inn gamli continue to maintain their household and status, other men are more adversely affected by the effects of aging. Egill Skallagrímsson, for example, whose eyesight and hearing diminish at old age, seems to suffer much more loss of agency in his household than the abovementioned men, suffering abuse and ridicule for his failing senses (Morcom 2018, p. 44-47, Clover 1993, Jakobsson 2005, p. 315-321, Helgadóttir Yershova 2008). Nevertheless, his place in the household is not without agency, and he still holds enough power to command enslaved people to hide his gold before he murders them (Tirosh 2020). Disabled children are of course in a very sensitive position; while there are no saga references to child exposure due to disabilities, legal evidence suffices to conclude that this was a consideration in parents' decisions to abandon a newly born child (Lawing 2013).

Since the main characters of the sagas are frequently prominent members of society, readers might get the sense that disabilities were, in fact, no matter at all for most people and that they did not pose a significant problem in terms of their access to exercising agency over themselves and others. It is therefore imperative to recognize that intersectional considerations are the key to understanding the different access to agency that is possible for people with disabilities in the sagas. As Metzler (2006) has pointed out, in the context of disability and in general, "[p]opular notions of the medieval period as dark, barbaric, and superstitious, to name but a few stereotypes, still abound" (p. 9). While physical, mental, and sensory differences certainly posed challenges to medieval Icelanders, it is clear that a more complex understanding of who is able and whose ability is questioned emerges from the medieval Icelandic sagas.

\section{Narrating difference}

The sagas provide a great deal of material through which to explore these questions. Yet, they are not mere vehicles for ideas. As Friðriksdóttir (2013) explains, the world of a given saga narrative "is an imagined space and as such obeys the laws of literary creations" (p. 3). When applying disability studies methods to the medieval sagas, scholars need not view and interpret these narratives solely as either literary creations or reflections of social attitudes and lived experiences. Indeed, being the product of some nebulous combination of enduring cultural memories and oral traditions, on the one hand, and creative historical interpretations and reconstructions 
of the past, on the other, saga narratives are particularly well-suited for the kind of hybrid methods that characterise disability studies as an academic discipline.

Like their counterparts in literary studies more broadly, scholars adopting a disability studies approach to the medieval sagas as literary creations have frequently focused on character depiction, including how physical, mental, and sensory differences are "translated into certain character traits," and not uncommonly negative ones (Bragg 1994, p. 31-32). On the one hand, certain of the effects of aging contribute to the common saga trope of the "nasty old man," including, for example, in Egils saga and Eyrbyggja saga, as discussed above. On the other hand, lasting physical injuries may just as commonly function as a sign of the hero in the sagas, acting as "proud tokens of properly reckless battle conduct" (Bragg 2004a, p. 92). This is the case, for example, in the legendary Ásmundar saga kappabana when the princess Æsa chooses Ásmundr over a rival suitor not despite but, at least in part, precisely because of the many scars and wounds on his arms (Detter 1891, p. 86-87, Künzler 2016, p. 259-265). Such "anomalies" are often simultaneously linked with poetic talents (Bragg 2004a, p. 193-238, Jakobsson 2014a). Yet, as John Sexton has shown, rather than providing a single definitive understanding of how such differences relate to character construction, saga narratives occasionally offer "multiple perspectives toward a right understanding of [their] meaning" without necessarily seeking resolution (Sexton 2020, p. 30, Sexton 2010, Künzler 2016).

In this way, the representation of physical, mental, and sensory differences in the sagas appear to fulfil some of the criteria of what Mitchell and Snyder (2000) referred to as "narrative prosthesis." Beyond its function as a direct reflection of characterisation, disability in literary narratives has also traditionally acted and has been interpreted as a wider index of moral standing, "offering the other characters opportunities to demonstrate whatsoever they might do to the least of their brothers" (Bérubé 2005, p. 270, Garland-Thomson 1997, p. 9-12). This also seems to be the case for the medieval sagas, wherein, for example, certain royal figures are defined by the way they respond to and care or fail to care for the physical and mental well-being of their followers (Crocker and Jakobsson 2021). Of course, the same can be said of religious authorities, particularly in hagiographic narratives, as indicated above. Yet, in other instances, mistreatment or abuse does not always register as a moral stain on the actors involved in such behaviour. For example, the way Gísli Súrsson exploits the identity and vulnerability of the aforementioned Helgi Ingjaldsson, who is better-known by the pejorative nickname Ingjaldsfifl, does not seem to tarnish the image of the saga's mostly sympathetic hero (Jakobsson et al. 2020, p. 456). In fact, there is no consistent moral index throughout saga writing arising from the ways other characters behave towards those who might be perceived as "the least of their brothers." 
More than simply vehicles for character description or development, embodied differences of a physical, mental, or sensory nature can also function as components of the narrative construction of the sagas. Bodies and minds that deviate sufficiently from perceived norms frequently demand a story of some kind, as they do in other or perhaps all literature (Bérubé 2005, p. 570, Davis 1995, p. 3-4; Mitchell and Snyder 2000, p. 6). Their appearance frequently prompts questions - either explicitly or implicitly concerning how the person got this way, whether they were always this way and will always be this way, and whether they can somehow overcome these circumstances or somehow be "fixed" (Titchkosky 2007, p. 177-207). In hagiographic narratives, such questions, and the answers they yield are situated within a decidedly Christian framework. Yet, other narratives navigate these matters in a variety of different ways. In Ragnars saga loðbrókar, for example, the narrative anticipates the question of how the defining physical feature of the above-mentioned Ívarr the bone-less comes about. The saga describes how Ívarr's father, preceded by his new wife's warning that they must wait three nights before consummating the marriage lest some harm will come to the child they will conceive, rapes Ívarr's mother on their wedding night (Olsen 1906-08, p. 128-129). Ívarr's "bone-less" body is depicted as a direct consequence.

Similarly, the question concerning not how she got that way but whether a nonspeaking woman named Oddný, who features in Forsteins páttr uxafóts, can somehow be "fixed" spurs her son's first heroic feat to discover a piece of gold that provides his mother with the ability to speak (Vilmundarson and Vilhjálmsson 1991, p. 339-370, Bragg 2004b, p. 280-285, Jakobsson et al. 2020, p. 451-455). Conversely, in Brennu-Njáls saga, one of the most well-known Íslendingasögur, there is seemingly no way for Otkell Skarfsson to overcome his poor eyesight, which makes riding difficult for him and leads to the nefarious Skamkell offering to attend an important meeting in his place. When Skammkell lies about the advice he receives at the meeting, which should have resulted in a peaceful settlement, the feud between Otkell and Gunnarr rapidly escalates. Otkell's poor eyesight may serve as a symbol of a lack of wisdom and his failure to see Skammkell for who he really is. More than this, however, it allows for the advancement of the saga's plot and fuels the narrative forward, doing so again when sometime later Otkell loses control of his horse and causes an injury to Gunnarr, reigniting what had become a dormant conflict (Sveinsson 1954, p. 128-138). Later in the same saga, a man named Ámundi inn blindi (the blind) appears to be granted vision by God long enough to avenge the killing of his father, which similarly allows for old hostilities to flare up once again, reopening the saga's central conflict between the Njálssons and the Sigfússons (Sveinsson 1954, p. 272-274, Walgenbach 2019). In both instances, blindness or poor vision, which is briefly overcome in the latter example, performs an important function in advancing the saga's plot and pushing the narrative forward. 
As in other literatures, in addition to sparking both "imagination and narration" (Hall 2015, p. 3-4), physical, mental, and sensory differences in the sagas also bear deeply complex relationships with the very conditions and possibilities of narrative itself. For example, apparent connections between trauma, physical injuries, or impairments inflicted through martial encounters, and the sometimes-conspicuous narrative silence surrounding the aftermath of these events provide deep insight toward the conditions of narratability in medieval saga writing (Heiniger 2020, Sexton 2010, p. 151-57). Somewhat similarly, questions concerning not only the conditions but even the possibility of narratability may be deeply entrenched in the representation, for example, of those with significant mental impairments whose capability for self-representation may be called into question. This may explain why such differences are so commonly found to be misunderstandings in the narratives in which they appear. The underlying perceptions of the mindedness or mindlessness of figures like the previously mentioned Helgi Ingjaldsson are deeply related to the possibilities of narratability, which frequently holds for modern literature as well (Bérubé 2005 , p. 572-573). Such perceptions invite interesting questions in relation to the sagas' tendency to avoid subjective positioning and to maintain an objective narrative style (Sävborg 2017, p. 112-115). On the other hand, the abovementioned Porsteins saga hvita, for example, makes remarkable use of the eponymous borsteinn's blindness to confront the otherwise ocularcentric norm of medieval saga writing (Crocker 2020). More than simply a prompt to tell a story, in this instance, Porsteinn's sensory difference functions as a narrative device that encourages the saga's audience to contemplate both the individual experience of blindness as well as the complex relationship between the senses and the possibilities and conditions of narrative itself.

\section{Conclusion}

Although the sagas present a number of challenges to scholars seeking to identify the precise nature of their source value, it is clear that they are incredibly rich sources concerning the ways medieval Icelanders experienced, communicated, represented, and interpreted physical, mental, and sensory differences. On a fundamental level, in terms of language and terminology, they provide vital evidence of the language used to identify such differences. However, this terminology, particularly those terms that appear to hold collective meanings, must be approached with the caveat that pre-modern words do not operate like modern concepts and the meaning of a given term can be remarkably inconsistent. Rising above the linguistic level, the sagas are no less valuable with respect to questions concerning the potentially disabling effects of embodied differences in medieval Iceland, but simple answers remain elusive. When seeking to understand disability in the context of medieval Iceland, scholars must 
avoid projecting their own contemporary assumptions about disability onto the past and recognise that the perception of and values assigned to physical, mental, and sensory differences are subject to a variety of social factors. Yet, despite their source value with respect to prevailing ideas and mentalities, it is also important to keep in mind that the medieval sagas are not documentary sources but are rather literary narratives. As such, their depiction of physical, mental, and sensory differences is deeply embedded in cultural conventions concerning character construction, plot development, and the very conditions and possibilities of narrative itself.

\section{References}

Aðalbjarnarson, B., ed., 1941-51. Heimskringla, 3 vol: Íslenzk fornrit 26-28. Reykjavík: Hið íslenzka fornritafélag.

Barthes, R., 1986. The reality effect. In: R. Barthes and H.R. Berkely, eds. The rustle of language. Berkeley and Los Angeles: University of California Press, 141-149.

Bérubé, M., 2005. Disability and narrative. PMLA, 120 (2), 568-576.

Bragg, L., 1994. Disfigurement, disability, and disintegration in Sturlunga saga. Alvissmál, 4, 15-32.

Bragg, L., 1997. Generational tensions in Sturlunga Saga. Arkiv för nordisk filologi, $116,5-34$.

Bragg, L., 2004a. Oedipus borealis: The aberrant body in old Icelandic myth and saga. Madison, NJ: Fairleigh Dickinson University Press.

Bragg, L., 2004b. Telling silence: Alingualism in old Icelandic myth, legend, and saga. Journal of Indo-European Studies, 32, 267-295.

Brynhildsvoll, K., 1993. Die strukturelle Antinomie von Heil und Unheil in der Isländersaga am Beispiel der Grettis saga Ásmundarsonar. In: K. Brynhildsvoll, ed. Der literarische Raum. Konzeptionen und Entwürfe. Frankfurt, DE: Peter Lang Publishing, 173-207.

Clover, C., 1993. Regardless of sex: Men, women, and power in Early Northern Europe. Representations, 44, 1-28.

Cock, E., and P. Skinner., 2019. (Dis)functional faces: Signs of the monstrous?. In: R. Godden and A. Mittman, eds. Monstrosity, disability, and the posthuman in the medieval and early modern world. Switzerland, CH: Palgrave Macmillan, 85-105.

Cohen, J.J., 2003. Medieval identity machines. Minneapolis: University of Minnesota Press.

Crocker, C., 2019. Disability and dreams in the medieval Icelandic sagas. SagaBook, 43, 39-58.

Crocker, C., 2020. Narrating blindness and seeing ocularcentrism in porsteins saga Hvita. Gripla, 31, 267-292.

Crocker, C., and Jakobsson, Á., 2021. The lion, the dream, and the poet: Mental illnesses in Norway's Medieval Royal Court. Mirator 20 (2), 91-105.

Davis, L.J., 1995. Enforcing normalcy: Disability, deafness, and the body. London and New York: Verso.

Detter, F., ed., 1891. Zwei Fornaldarsögur (Hrólfs saga Gautrekssonar und Ásmundarsaga Kappabana) nach cod. Holm. 7, 4to. Halle, DE: Max Niemeyer.

Egilsdóttir, Á., 2002. Porláks saga. In: Á. Egilsdóttir, ed., Biskupa sögur II. Íslenzk fornrit 16. Reykjavík: Hið íslenzka fornritafélag. 
Egilsdóttir, Á., 2005. Kolbítur verður karlmaður. In: Á. Jakobsson and T. H. Tulinius, eds. Miðaldabörn. Reykjavík: Hugvísindastofnun, 87-100.

Einarsson, B., ed., 1985. Ágrip af Noregskonungasögum. Fagrskinna - Noregs konunga tal. Reykjavík: Hið íslenzka fornritafélag.

Erlingsson, D., 1992. Saga gerir mann: Hugleiðing um gildi og stöðu hugvísinda. Skirnir, 166, 321-345.

Evans, G.L., 2019. Men and masculinities in the sagas of icelanders. Oxford: Oxford University Press.

Eyler, J.R., ed., 2010. Disability in the middle ages: Reconsiderations and reverberations. Farnham, UK: Ashgate.

Friðriksdóttir, J.K., 2013. Women in old Norse literature: Bodies, words, and power. New York: Palgrave Macmillan.

Garland-Thomson, R., 1997. Extraordinary bodies: Figuring physical disability in American culture and literature. New York: Columbia University Press.

Hall, A., 2015. Literature and disability. London and New York: Routledge.

Hall, A., Richardson, S.D.P., and Porgeirsson, H., eds., 2013. Sigrgarðs saga frækna: A normalised text, translation, and introduction. Scandinavian-Canadian Studies/ Études Scandinaves au Canada, 21, 80-155.

Heiniger, A.K., 2020. The silenced trauma in the Íslendingasögur. Gripla, 31, 233-265.

Helgadóttir Yershova, Y.S., 2008. Egill Skalla-Grímsson: A viking poet as a child and an old man. In: S. Lewis-Simpson, ed. Youth and age in the medieval north. Leiden, DE: Brill, 285-304.

Higman, J., 2021. Nobody's fífl: Representations of intellectual disability in Old Norse-Icelandic literature. Mirator 20 (2), 73-90.

Hsy, J., Pearman, T.V., and Eyler, J.R., ed., 2020. A cultural history of disability in the middle ages. London: Bloomsbury.

Jakobsson, Á., 2005. The specter of old age: Nasty old men in the sagas of Icelanders. JEGP, 104 (3), 297-325.

Jakobsson, Á., 2014a. The homer of the north or: Who was Sigurður the blind?. European Journal of Scandinavian Studies, 44 (1), 4-19.

Jakobsson, Á., 2014b. The madness of king Sigurðr: Narrating insanity in an old Norse kings' Saga. In: S. Crawford and C. Lee, eds. Social dimensions of medieval disease and disability. Oxford: Archaeopress, 29-35.

Jakobsson, Á., 2015. King Arthur and the Kennedy assassination: The allure and absence of truth in the Icelandic sagas. Scandinavian-Canadian Studies, 22, 13-25.

Jakobsson, Á., and Guðjónsson, P.I., eds., 2011. Morkinskinna: Íslenzk fornrit 23-24. Reykjavík: Hið íslenzka fornritafélag.

Jakobsson, Á., Heiniger, A.K., Crocker, C., and Sigurjónsdóttir, H.B., 2020. Disability before disability: Mapping the uncharted in the medieval sagas. Scandinavian Studies, 92 (4), 440-60.

Jiriczek, O.L., ed., 1893. Die Bósa-Saga in zwei Fassungen nebst Proben aus den Bósa-Rímur. Strassburg, DE: Karl J. Trübner.

Jóhannesson, J., 1950. Porsteins saga hvita. In: J. Jóhannesson, ed. Austfirðinga sogur: Íslenzk fornrit 11. Reykjavík: Hið íslenzka fornritafélag.

Jónsson, F., 1907. Tilnavne i den islandske oldlitteratur. Aarbøger for Nordisk Oldkyndighet og Historie, 22, 161-381.

Jónsson, G., ed., 1936. Grettis Saga Ásmundarsonar: Íslenzk fornrit 7. Reykjavík: Hið Íslenzka fornritafélag. 
Jørgensen, K.G., 1990. Ég var sjónar vottur! Hvað gerðist? Um tíma og frásögn í Íslendingasögum. Skáldskaparmál 1, 264-86.

Künzler, S., 2016. Flesh and word: Reading bodies in old Norse-Icelandic and early Irish literature. Berlin and Boston: De Gruyter.

Laes, C., 2019. Power, infirmity, and "disability." Five case stories on byzantine emperors and their impairments. Byzantinoslavica, 77, 211-229.

Lassen, A., 2003. Øjet og blindheden: I norrøn litteratur og mytologi. Copenhagen: Museum Tusculanums Forlag Kobenhavns Universitet.

Lawing, S., 2013. The place of evil: Infant abandonment in old Norse society. Scandinavian Studies, 85 (2), 133-150.

Lawing, S., 2014. Re-membering Auðr's Hand in Eyrbyggja Saga. International medieval congress: The literature of medieval scandinavia, III: Political, cultural, and mythological empires. Leeds, UK: University of Leeds.

Lawing, S., 2016. Perspectives on disfigurement in medieval iceland: A cultural study based on old Norse laws and Icelandic sagas. Thesis (PhD). University of Iceland.

Lawing, S., 2021. Victims of maiming in Sturlunga saga: Worse off living than dead? Mirator 20 (2), 54-72.

Loth, A., ed., 1962. Late medieval romances 1. Copenhagen: Reitzel.

Metzler, I., 2006. Disability in medieval Europe: Thinking about physical impairment during the high middle ages, $c$. 1100-1400. London: Routledge.

Metzler, I., 2013. A social history of disability in the middle ages: Cultural considerations of physical impairment. London: Routledge.

Meulengracht-Sørensen, P., 1992. Some methodological considerations in connection with the study of the sagas. In: G. Pálsson, ed. From Sagas to Society: Comparative Approaches to Early Iceland. Enfield Lock: Hisarlik Press, 27-41.

Michelson-Ambelang, T., 2015. Outsiders on the Inside: Conception of Disability in Medieval Western Scandinavia. Thesis (PhD). University of WisconsinMadison.

Mitchell, D.T., and Snyder, L.S., 2000. Narrative prosthesis: Disability and the dependencies of discourse. Ann Arbor, MI: The University of Michigan Press.

Morcom, T., 2018. After adulthood: The metamorphoses of the elderly in the Íslendingasögur. Saga-Book, 42, 25-50.

Nolte, C., B. Frohne, U. Halle., and S. Kerth, eds., 2017. Dis/ability History der Vormoderne: ein Handbuch. premodern dislability history: A companion. Affalterbach: Didymos.

Olsen, M., ed., 1906-08. Völsunga saga ok Ragnars saga loðbrókar. STUAGNL 36. Copenhagen: S. L. Møllers.

Overing, G., 1999. A body in question: Aging, community, and gender in medieval Iceland. Journal of Medieval and Early Modern Studies, 29 (1), 211-225.

Rikhardsdottir, S., 2017. Medieval emotionality: The feeling subject in medieval literature. Comparative Literature, 69 (1), 74-90.

Ronen, M., 2018. A still sound mind: Personal agency of impaired people in Anglo-Saxon care and cure narratives. In: E. Connelly and S. Künzel, eds. New approaches to disease, disability, and medicine in medieval Europe. Oxford: Archaeopress, 19-30.

Sexton, J.P., 2010. Difference and disability: On the logic of naming in the Icelandic Sagas. In: J.R. Eyler, ed. Disability in the middle ages: Reconsiderations and reverberations. London and Burlington, VT: Ashgate, 149-163. 
Sexton, J.P., 2020. Atypical bodies: Seeking after meaning in physical difference. In: J. Hsy, T.V. Pearman, and J.R. Eyler, eds. A cultural history of disability in the middle ages. London: Bloomsbury, 19-34.

Sveinsson, E.Ó., ed., 1934. Laxdæla saga: Íslenzk fornrit 5. Reykjavík: Hið íslenzka fornritafélag.

Sveinsson, E.Ó., ed., 1935. Eyrbyggja saga: Íslenzk fornrit 4. Reykjavík: Hið íslenzka fornritafélag.

Sveinsson, E.Ó., ed. 1954. Brennu-Njáls saga: Íslenzk fornrit 12. Reykjavík: Hið íslenzka fornritafélag.

Sävborg, D., 2017. Style. In: Á. Jakobsson and S. Jakobsson, eds. The Routledge research companion to the medieval Icelandic saga. London: Routledge, 111-126.

Teichert, M., 2016. The sorcerous succubus from samiland. Monstrous womanhood and the abject in the Snæfríðr episode of Haralds saga hárfagra. In: D. Hahn and A. Schmidt, eds. Bad boys and wicked women. antagonists and troublemakers in old Norse literature. München, DE: Utz, 198-214.

Tirosh, Y. 2019. On the receiving end: The role of scholarship, memory, and genre in constructing Ljósvetninga saga. Ph.D. diss., University of Iceland.

Tirosh, Y., 2020. Deafness and non-speaking in late medieval Iceland (1200-1550), Viator 51.1.

Titchkosky, T., 2007. Reading and writing disability differently: The textured life of embodiment. Toronto: University of Toronto Press.

Tovey, B., 2010. Kingly impairments in Anglo-Saxon literature: God's curse and God's blessing. In: J.R. Eyler, ed. Disability in the middle ages: Reconsiderations and reverberations. Surrey, UK: Palgrave, 135-148.

Turner, W.J., 2010. A cure for the king means the health of the country: The mental and physical health of henry VI. In: W.J. Turner, ed. Madness in medieval law and custom. Leiden, NL: Brill, 177-195.

Unger, C.R., ed., 1874. Postola sögur, Kristiania, NO: Bentzen.

Unger, C.R., ed., 1871. Maríu saga, Kristiania, NO: Brøgger \& Christie.

Unger, C.R., and Vigfússon, G., eds., 1868. Flateyjarbok III. Kristiania, NO: Malling.

Vilmundarson, P., and Vilhjálmsson, B., eds., 1991. Harðar saga: Íslenzk fornrit 13. Reykjavík: Hið íslenzka fornritafélag.

Walgenbach, E., 2019. Inciting miracle in Njáls saga: Ámundi hinn blindi’s gift of sight in context. Saga-Book, 43, 125-136.

Whaley, D., 1993. Nicknames and narratives in the sagas. Arkiv för nordisk filologi, $108,122-146$.

Willson, K.J., 2008. 1400 Icelandic nicknames. In: G. Kvaran, ed. Norran nöfnNöfn á Norðurlöndum. Hefðir og endurnýjun. Nordiska namn-Namn i Norden. Tradition och förnyelse. Handlingar från Den fjortonde nordiska namnforskarkongressen i Borgarnes. Reykjavík: Stofnun Árna Magnússonar í íslenskum fræðum, 487-493.

Wilson, J., 2016. Inter-crural relations: Abnormal representations of legs and feet in the Icelandic fornaldarsögur. Thesis (MA). University of Iceland.

Wolf, K., 2018. "Engi er allheimskr, ef pegja má": Women and silence in the sagas and pattir of Icelanders. Maal og minne, (2): 115-126.

Wäckerlin, H., 2006. The silence of Sigurðr pögli - Vox Articulata, Vox Humana, and Vox Animalia in Sigurðar saga pögla. In: J. McKinnell, D. Ashurst, and D. Kick, eds. The fantastic in old Norse/ICELANDIC literature: Sagas and the British 


\section{C. Crocker et al.}

isles: Preprint papers of the thirteenth international saga conference Durham and York 6-12 August. Durham, UK: Centre for Medieval and Renaissance Studies, Durham University, 1005-1014.

porláksson, G., ed., 1880. Glúma og Ljósvetninga saga: Íslenzkar fornsögur, Vol. 1. Copenhagen: Hið Íslenska bókmenntafélag.

Pórólfsson, B.K., and Jónsson, G., 1943. Gísla saga Súrssonar. In: B.K. Pórólfsson and G. Jónsson, eds. Vestfirðinga sögur. Íslenzk fornrit 6. Reykjavík: Hið íslenzka fornritafélag. 


\title{
2 Beneath the Surface \\ Disability in archaeological and osteobiographical contexts
}

\author{
Steinunn Kristjánsdóttir and Joe W. Walser III
}

\section{Introduction}

Congenital, infectious, or traumatic pathologies diagnosed from human skeletal remains may at first sight be observed as splendid sources to investigate concepts, such as disability in the past. However, given the fact that disability is simultaneously a social construct, different between societies and even variable over time within each society, the task to determine such intangible information from skeletal remains may prove difficult or even impossible. Explicitly, although skeletal remains are certainly the keepers of human biographies, in regard to injuries, inborn or acquired impairments, traumata, food consumption, occupation, and many more, such data rarely includes information about their observations during life. Furthermore, neither impairments nor skeletal changes necessarily indicate disability and inversely individuals can become disabled without having observable impairments (Roberts 2000, Murphy 2000, Groves 2003, Battles 2011).

This approach to disability, in fact, has its roots in the post-humanistic discourse that seeks to focus on the ongoing and multifaceted encounters of nature and culture in the past as well as the present, whereas in humanism humans were observed as the main force behind social and cultural developments without the notice of natural mechanisms that simultaneously influence their observations and thoughts (Hayles 1999. Braidotti 2006, p. 197-208, Callus and Herbrechter 2013, p. 144-153). Accordingly, disability justifiably requires both the impaired body and specific social adherences in order to exist. However, even though the premise of posthumanism declares that disability is simultaneously a social and biological construct, a wide range of bodily impairments may more likely imply reduced quality of life but only in the context of what the social environment can offer. Therefore, rather than focusing solely on impairments in this chapter, the spotlight will concurrently be directed at the socially based opportunities of people living with severe impairments to improve the quality of their lives and how these factors may affect the potential process of becoming disabled. This chapter deals, thus, not only with the question of if and how physically disabling impairments appearing 
in skeletal remains can be used to explore disability as a social construct in the past. It seeks moreover to consider the issue of whether impairing conditions may rather highlight the reduced possibility of people to live without being imprinted as disabled and the applied ways of adapting to the experienced situation.

The excavation of the monastic site of Skriðuklaustur, East Iceland, will be used for this study, wherefrom skeletal remains of five individuals will specifically be examined within the context of the advanced hospital that was run at this monastery which was established in 1494 and closed down due to the Reformation in the mid-16 ${ }^{\text {th }}$ century. The research intends to discuss both the social and medical treatment of individuals facing pathological conditions that sought care at this monastic site in question. They could have come there as patients either seeking medical treatment or salvation or even as outcasts searching for shelter from society. Grave context and the burial practises applied in the past can surely shed light on certain aspects of the broader society and all such information will be used here accordingly, besides other contextual data on the Icelandic late medieval society. Consequently, by considering the treatment of bodily impairments and the social circumstances of individuals facing potential disabling conditions from one site might provide further possibilities to examine evidence of disability in past societies in general.

The aim of the osteological analysis was to investigate each skeletal individual's overall health conditions and identify bone changes suggestive of physical impairments could potentially lead to socially disabling conditions. Previously published trace element and isotope results were used in combination with standard and specialised osteological methods to provide deeper context (Walser III et al. 2019, 2020a, 2020b, 2021). The osteological results were considered within the greater archaeological context and were informed by historical records and secondary data.

\section{Impairments or disability?}

Disability is socially and environmentally imposed, often occurring in combination with physical, cognitive, or sensory impairment, and illness. Knudson and Stojanowski (2008) states, furthermore, that bioarchaeologists have increasingly distinguished between disease, impairment, and disability, as disease is a temporary or permanent pathological condition while impairment is a physical or mental state that may result from a disease. Thus, disability refers on the other hand to the relationship between society and individuals with impairments. Moreover, overall health, social support, and access to treatment can significantly influence the extent of experienced disability. Not all individuals experience the same condition in the same way. For example, pain is tolerated at different values by every individual and is socially shaped by ethnicity, sex, age, overall health, and cultural factors. People also undergo "adaptation" and thus, what may 
be experienced as a painful condition to one person may go unnoticed by another (Roberts 2000, Waldron 2007). Perception and acceptance of disability can also dramatically change over time within a society, such as occurred with tuberculosis, which was sometimes romanticised as a fashionable, creative impetus in the $17^{\text {th }}$ century before it was redefined in the $19^{\text {th }}$ century as an affliction of the poor and "inferior" resulting from bad behaviour (Roberts 2000).

Some secondary sources (e.g., art, written descriptions, and iconography) suggests marginalisation and mistreatment of the sick and disabled in some past populations, while other evidence suggests care and nondifferential treatment (Groves 2003, Bethard et al. 2017). There is iconographic evidence of the use of devices, such as crutches and artificial limbs to aid impaired individuals, but little physical evidence of these implements is preserved today. Neither treatment and care nor social acceptance are the same everywhere and although it can sometimes be seen that interpersonal care was required for survival it does not necessarily imply that an individual was socially accepted despite their disability (Stirland 1997). Class differences affected access to treatment, overall health and cultural acceptance and some scholars suggest that impaired and disabled people were often poor due to their occupational limitations and exclusion from certain social arenas (Roberts 2000). However, historical records and skeletal evidence clearly show that high-status individuals also experienced potentially disabling impairments, such as due to disease and congenital conditions (Roberts 2000, Groves 2003). They are also more likely to suffer from diseases of affluence and abundance, such as those resulting from alcoholism, obesity, and purine-rich diets (i.e., gout) (Roberts and Manchester 2010).

This being said, skeletal evidence of impairment does not directly reveal disability, regardless of the severity of bone changes, but may indicate that the individual faced decreased ability, function, or mobility for some period during their life (Bethard 2017). However, other scholars note that the extent of functional limitations associated with bodily impairments cannot be assumed because the same conditions are not necessarily experienced the same way between individuals or even populations (Kasnitz and Shuttleworth 2001, Roberts 2000). Additionally, an individual with an initially impairing condition may "adapt" and never face disability (Sugiyama 2004, Roberts 2000). Still, physical impairments, such as bone fractures, always have the potential to heal or vanish as well, especially with treatment (Waldron 2007). Additionally, many bodily impairments are only expressed in soft tissues, which are in fact rarely recovered from archaeological contexts. Disability, however, extends beyond skeletal and general bodily impairments to conditions that cannot be observed from physical remains (e.g., sensory, and psychological or cognitive impairments) (Jeffreys and Tait 2000, Zakrewski 2014). Thus, we cannot establish the frequency or prevalence of disability in archaeological populations 
because we cannot directly observe disability based solely upon skeletal impairments (Roberts 1999, Cross 2007, Zakrewski 2014).

Furthermore, linking skeletal data to secondary data, such as written records, is often presumptuous and inaccurate as bone displays a limited range of reactive change to a markedly wide range of aetiologies that may all result in the same impairment (Roberts 1999, Mitchell 2011). Other complications arise from changing understandings of pathological conditions over time, the disappearance and emergence of some diseases, inadequate translations of historical records, and the presence of concurrent conditions (Mitchell 2011). In the archaeological context we must attempt to frame our perspectives on past disability without inferring causative values about past social perspectives based solely upon pathological lesions, irregular skeletal development, and other variations (Roberts 1999, 2000, Zakrewski 2014, Bethard 2017).

\section{Skriðuklaustur}

Skriðuklaustur monastery was established in 1494 on the farm of Skriða, located in the inland valley of Fljótsdalur in East Iceland. It was run according to the Rule of the Augustinian Order until the Reformation in the mid-16th century. During an excavation, undertaken on the monastic ruins in 2002-2012, a total of 298 graves were found buried in its cemetery. Burials provided important information about the inhabitants of the monastery and its aim, by proving that this was not solely the resting place for the resident canons. The burial context and skeletal findings demonstrated that in the monastery, a multitude of people lived and died - people who obviously sought aid there because they suffered from a wide range of afflictions, brought on by disease, injuries, health stress, and birth conditions. Furthermore, many of the patients who made their way to Skriðuklaustur had clearly been afflicted with severe, chronic illnesses. More than half of the skeletons excavated from its cemetery showed bone changes indicative of various diseases, revealing that the canons at Skriðuklaustur ran an advanced hospital serving people of both sexes, all ages, and social classes. Furthermore, both the artefacts and medicinal plants, found at the monastery point towards attempts to provide healing to their patients. Instruments, such as lancets, scalpels, and needles were among the finds, as well as evidence of non-native medicinal plants, growing at the monastery. Imported mercury was also used as a chemo-therapeutic treatment for healing various conditions, especially those causing skin lesions (Kristjánsdóttir 2012, p. 277-283, Kristjánsdóttir, Larsson and Åsen 2014, Walser III et. al. 2019 , p. $48-61)$. Isotope $\left(\delta^{18} \mathrm{O},{ }^{87} \mathrm{Sr} /{ }^{86} \mathrm{Sr}, \delta^{13} \mathrm{C}\right.$, and $\left.\delta^{34} \mathrm{~S}\right)$ and trace element $(\mathrm{Pb}, \mathrm{Sr}, \mathrm{Zn}, \mathrm{Cd}, \mathrm{Sb}, \mathrm{Hg}, \mathrm{As}$, and $\mathrm{Ba}$ ) analyses conducted to investigate the geographic provenance of the people buried at Skriðuklaustur showed, furthermore, that they were locals, coming exclusively from the south-eastern quarter of the country. It is worth noting that in the vernacular land law of 
that time, Jónsbók (Jónsson 2004, p. 141-149), the counties and relatives of those in need were obliged to take care of them. However, it seems clear that Skriðuklaustur offered, nevertheless, an additional option for the public in this manner, though this may have mostly been done in extremely severe cases, such as if people became outcasts, homeless or otherwise socially marginalised due to their impairments.

\section{The cases from Skriðuklaustur}

The cases from Skriðuklaustur chosen for this study are as follows: Metabolic insult, cleft premaxilla (lip) and maxilla (palate) (SKR 22), treponemal disease (syphilis) (SKR 23), Hydatid disease, tuberculosis, and mobility impairment (SKR 128), Traumatic injury and comorbidities (SKR 130), and Paget's disease of bone (SKR 174). The osteological summaries for the five cases discussed below are presented in Table 2.1.

The individual identified as SKR 22 was an older teenager at time of death. While osteological methods cannot be accurately used to determine sex in human non-adults, the individual was identified as male through ancient DNA analysis. The occipital, frontal, and right parietal bones have concave, reactive cranial lesions, which could potentially have been caused by an infection, such as treponemal disease. However, the lesions do not bear the typical appearance of caries sicca and may instead originate from traumatic injuries or other pathological processes. Regardless, treponemal disease is an important differential diagnosis in this case, especially considering the individual's young age-at-death and other comorbidities. If the depressed cranial lesions resulted from traumatic injury, an accident, interpersonal violence or even child abuse could potentially be indicated. The right tibial tuberosity (upper part of shinbone) also had evidence of a healed traumatic injury, such as an incomplete fracture, which is the most common type of fracture affecting nonadults.

The individual also had a congenital cleft premaxilla (lip) and maxilla (palate), conditions only seen in a handful of cases in the Icelandic skeletal record (See Fig. 2.1). Congenital orofacial clefts or perforations, which often cause significant problems in eating, drinking, and speaking, result from defects occurring during embryological development of the maxillary, premaxillary, and palatal structures (Bhattacharya et al. 2009). Infants born with congenital cleft palate normally have difficulty breastfeeding and take longer than other children to start eating solid food (Müldner et al. 2009). Until the $19^{\text {th }}$ century when the successful surgical correction of cleft lips and palates commenced, infants in the past would have required significant social care to survive, especially for the first year of the life when they require careful handfeeding to receive adequate nutrition (Bragg 1994, Bhattacharya et al. 2009). Bioarchaeological investigations of care in the past have indicated that people born with cleft palates did not necessarily always experience social marginalisation 
Table 2.1 Osteological summaries for the five cases discussed in this research. Original data published in Kristjánsdóttir (2011, 2012), Kristjánsdóttir and Collins (2011) and Walser et al. (2019, 2020a, 2020b, 2021)

Osteological summary

\begin{tabular}{|c|c|c|c|c|c|c|}
\hline Skeleton ID & Preservation & Completeness & Sex & Age & Stature & Pathology \\
\hline SKR 22 & 1 & $90 \%$ & Male $^{\mathrm{a}}$ & $15-17$ & $\sim 125 \mathrm{~cm}$ & $\begin{array}{l}\text { Cleft maxilla and premaxilla. Treponemal disease. Linear enamel } \\
\text { hypoplasia. Incomplete tibial fracture (right) resulting in secondary } \\
\text { infection of the distal right femur and proximal tibia. }\end{array}$ \\
\hline SKR 23 & 1 & $90 \%$ & Female & $17-25$ & $\sim 154 \mathrm{~cm}$ & $\begin{array}{l}\text { Cranial stellate scarring (caries sicca) on almost all cranial bones } \\
\text { (especially on ectocranial vault). Gummatous lesions on long bones. } \\
\text { Osteitis and anterior bowing of tibiae. Evidence of non-specific } \\
\text { respiratory disease in the form of lytic lesions and new bone formation } \\
\text { on multiple ribs. }\end{array}$ \\
\hline SKR 128 & 2 & $90 \%$ & Female & $45+$ & $\sim 154 \mathrm{~cm}$ & $\begin{array}{l}\text { Spinal kyphosis (possible tuberculosis) from collapse of 2nd lumbar } \\
\text { vertebra. Button osteomata ( } 3 \text { ) on frontal bone. X vertebral } \\
\text { compressions fractures. Healing cranial lesion (circular, concave lesion } \\
\text { with reactive new bone). Linear enamel hypoplasia. }\end{array}$ \\
\hline SKR 130 & 2 & $90 \%$ & Male & $26-35$ & $\sim 161 \mathrm{~cm}$ & $\begin{array}{l}\text { Pronounced lingual wear on maxillary incisors and canines. Large ( }>7 \\
\text { mm Ø), externally draining mandibular (L PM1, PM2, M1) and } \\
\text { maxillary (L M2, M3; R M3) periapical lesions. Nodular, lamellar } \\
\text { bone formation throughout ribs (respiratory disease). Distal right } \\
\text { femur (healed or unhealed) fractured. Tibiae, femora, parietals and } \\
\text { frontals with gummatous lesions (treponemal disease). Tibia and } \\
\text { femora with osteitis. Left clavicle with lytic lesion and bone destruction } \\
\text { on sternal joint surface. }\end{array}$ \\
\hline SKR 174 & 2 & $<50 \%$ & Male & $45+$ & $\sim 166 \mathrm{~cm}$ & $\begin{array}{l}\text { The scapula, skull, and long bones exhibit exaggerated expansion, } \\
\text { porosity, osteitis, and new bone formation (Paget's disease of bone). } \\
\text { Bilateral cribra orbitalia. Large ( }>7 \mathrm{~mm} \varnothing \text { ) external draining periapical } \\
\text { lesion (R Max. M2). Right maxillary dentition with slight calculus and } \\
\text { alveolar bone with slight resorption (periodontal disease). Degenerative } \\
\text { joint disease and/or osteoarthritis on all observable joint surfaces. }\end{array}$ \\
\hline
\end{tabular}

Notes: Preservation was graded 0 (no modification) to 5+ (heavy erosion) according to Brickley and McKinley (2004).

${ }^{a}$ Sex of SKR 22 revealed by aDNA analysis (unpublished results). 

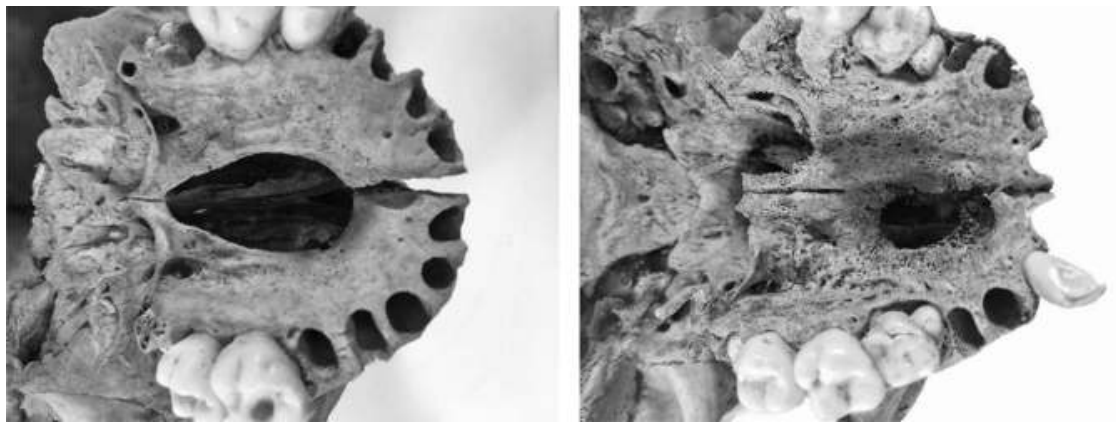

Figure 2.1 Left, inferior view of the cleft maxilla and premaxilla from SKR 22. Right, for comparison, is the inferior view of the maxilla of another individual (SKR 201) with palatal perforations resulting from an infectious process, such as from treponemal disease, rather than from congenital or developmental defects. (C) Joe W. Walser III, National Museum of Iceland.

and in some cases may have even been honoured, considering their survival into adulthood and the nondeviant burials they are typically recovered from (Curry, 2019). In the Icelandic narrative of Porgils skarða from Sturlunga saga $\left(13^{\text {th }}-14^{\text {th }}\right.$ centuries $)$, a man known as Porgils skarði Böðvarsson is described as strong, trustworthy, and handsome despite his cleft lip, from which his name "skarði" originated (Bragg 1994). This description implies that at least some individuals with disfiguring or physically impairing conditions were revered in Icelandic society rather than socially marginalised.

The results of isotope analyses $\left(\delta^{18} \mathrm{O},{ }^{87} \mathrm{Sr} /{ }^{86} \mathrm{Sr}, \delta^{13} \mathrm{C}\right.$, and $\left.\delta^{34} \mathrm{~S}\right)$ show that he was born in Iceland and likely immigrated to Skriðuklaustur from somewhere within the south-eastern quarter of the country (Walser et al. 2020a). Perhaps his family took him to the monastery to seek aid or treatment in managing his health conditions, however, it cannot be ruled out that he managed to travel there on his own. Isotope results $\left(\delta^{13} \mathrm{C}, \delta^{15} \mathrm{~N}\right.$, and $\delta^{34} \mathrm{~S}$ ) showed that he was the only analysed individual from the site $(n=31)$ that consumed a wholly terrestrial diet, while the rest of the sample population had a diet dominated by mixed marine protein and terrestrial resources supplemented with freshwater fish (Walser et al. 2020a). He also faced a period of health stress, infection or malnutrition that was indicated by linear enamel hypoplasia on about half of his teeth. Considering the congenital orofacial clefts and the comorbidities of trauma and possible infectious disease, poor overall health and dietary restrictions may explain why he consumed a different diet than the other people residing at Skriðuklaustur. It is also possible that the previously mentioned period of health stress in childhood - indicated by linear enamel hypoplasia - is associated with poor nutrition resulting from eating difficulties caused by the orofacial clefts. 


\section{Treponemal disease (Probable Venereal Syphilis) (SKR 23)}

The individual identified as SKR 23 was a young adult (ca. 17-25) at the time of death. Her skeletal remains show advanced bone changes consistent with treponemal disease (probable venereal syphilis), according to the criteria described by Hackett (1976) and Ortner (2003) (See Fig. 2.2). The skeleton exhibits gummatous and lytic lesions on the cranium (stellate scarring) and long bones, osteitis and bowing of lower leg bones (tibiae) and cribra orbitalia. At least nine individuals found at Skriðuklaustur had skeletal changes indicative of treponemal disease, specifically probable venereal syphilis, a sexually transmitted disease caused by a spirochete organism called treponema pallidum (Walser III et al. 2019). While the initial phases (primary and secondary) can cause pain, psychological impairment and disfiguring bodily changes, a latent stage void of these signs and symptoms that may last for years follows (Meyer et al. 2002, Crozatti et al. 2015). Advanced skeletal changes associated with venereal syphilis often do not appear until the tertiary stage, which could take as long as 10-30 years to emerge after the infection begins and can be fatal (Ortner 2003). Considering her young age at death, the extensive skeletal changes observable in the young adult female described here (SKR 23) indicate that she likely initially acquired the infection at a young age, perhaps as a teenager. The discovery of several individuals with late stage treponemal disease at Skriðuklaustur suggests that the disease spread to Iceland about the same time that the first

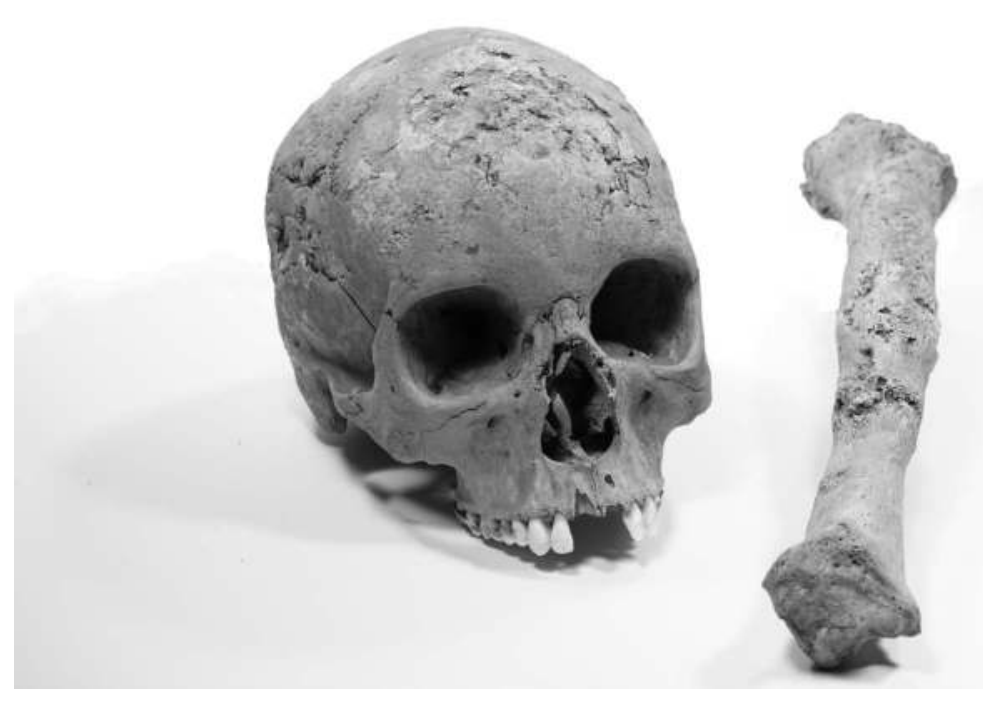

Figure 2.2 Cranium and tibia of young adult female individual (SKR 23) with bone changes suggestive of treponemal disease (probable venereal syphilis). (C) Joe W. Walser III, National Museum of Iceland. 
known outbreak occurred throughout western Europe (ca. 1494-1495) (Kristjánsdóttir 2011, Walser III et al. 2019).

Venereal syphilis is caused by sexual contact or contact with syphilitic lesions or bodily fluids, or rarely, while using contaminated objects. It can also be acquired congenitally through transplacental infection in utero if the mother is infected (Meyer et al. 2002). At the time, it was believed that people contracted serious illnesses and impairments, such as venereal syphilis and blindness, due to divine punishment for sin or from bad air and blood (Meyer et al. 2002, Woolgar 2006). Venereal syphilis significantly impacted public health and living conditions across Europe, requiring society to renegotiate cultural behaviour in everyday life: Sanctions were placed on prostitution, religious devoutness was emphasised, and public baths were closed. The widespread use of wigs and gloves may have been used to conceal disfiguring syphilitic lesions, implying that people infected with syphilis faced social stigma and shame in Medieval society. These various cultural changes were thus conducive to the "prudeness" often associated with the Reformation (Meyer et al. 2002, Woolgar 2006).

In the past, mercury, which is highly toxic, was used to treat venereal syphilis and other medical conditions, especially those that cause dermatological lesions. Evidence for the use of mercury as a medicine has been discovered at archaeological hospitals and monasteries (Rasmussen et al. 2015). In a study by Tucker (2007), it was noted that skeletons displaying the most extensive bone changes are also the ones that had lower mercury concentrations, which may suggest that treatment with it reduced reactive bone changes. In the case described here, despite the advanced skeletal changes, she (SKR 23) presents with a low bone mercury concentration, within the normal range (Walser III et al. 2019, 2021.). On the other hand, it is also possible that she did not survive long enough to undergo treatment, refused treatment altogether, died shortly after treatment started, or died due to a comorbidity or even mercury poisoning, especially considering the nonstandardised dosage that was used in the $16^{\text {th }}$ century (Ioannou et al. 2016). Mercury poisoning can cause tooth and hair loss, severe dermal lesions and potentially irreversible psychological impairments and could not be treated in the past (Boyd et al. 2000, Crozatti et al. 2015). Other individuals with treponemal disease (SKR 201) had exceedingly high mercury concentrations, indicative of both medical treatment and potentially mercury poisoning resulting from it (Walser et al. 2019, Walser 2021). Thus, it is uncertain whether its use as a medicine resulted in harm or rather in healing, however, anecdotal evidence from $19^{\text {th }}$ century Iceland claim that it successfully treated some cases of hydatid disease and venereal syphilis (Hjaltelin 1868, 2013).

\section{Hydatid disease, tuberculosis, and mobility impairment (SKR 128)}

The individual identified as SKR 128 was female, and she was an older adult (45+) at the time of death. The individual was infected with hydatid disease caused by a parasite known as echinococcus granulosus, which was 


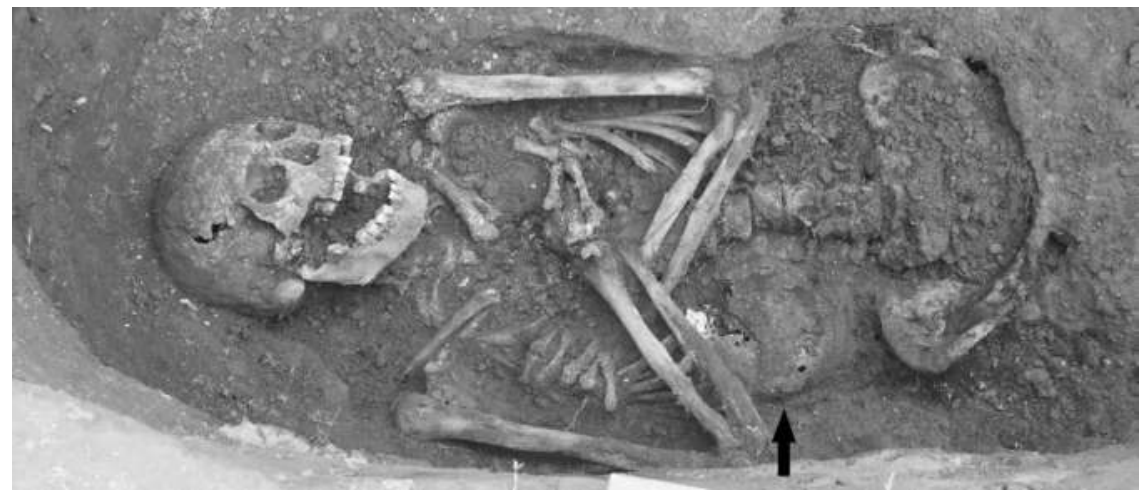

Figure 2.3 The individual (SKR 126) from Skriðuklaustur with possible comorbidities of hydatid and treponemal disease. The black arrow indicates the ossified hydatid cyst (C Steinunn Kristjánsdóttir, University of Iceland).

introduced to Iceland during the Settlement. The parasite has a lifecycle involving canids (e.g., dogs) and ungulates (e.g., sheep) as definitive, and intermediate hosts, respectively. In Iceland, the transmission was promoted by the practice of home butchering sheep and feeding their offal to farm dogs. It became endemic by the $13^{\text {th }}$ century and was finally eradicated in the $19^{\text {th }}$ century following extensive public outreach and education. At least 13 skeletons excavated from the cemetery at Skriðuklaustur presented with calcified hydatid cysts (See Fig. 2.3, Kristjánsdóttir and Collins 2011, Walser et al. 2021). Hydatid infections can remain active for decades while the parasites reproduce and the condition causes shock, allergic reactions, increased bone fracture rates, pain, osteosclerosis, and other signs and symptoms. Cysts may take as long as a decade to grow substantially, do not always ossify and, even if ossified, are not always well preserved in archaeological contexts, indicating that the disease burden was probably higher than it appears from the skeletal record (Moro and Schantz 2009, Kristjánsdóttir and Collins 2011, Walser et al. 2021). The cysts can develop in the kidneys, lungs, liver, spleen, bones or central nervous, and may grow to a very large size over time, causing pain, vomiting or nausea, and becoming externally visible, which may potentially be disfiguring (Kosmidis et al. 2018).

The biceps brachiorum of the humeri (upper arms) showed pronounced entheseal attachment sites, skeletal markers that are often associated with physical activity and occupation. However, numerous studies have shown that increased entheseal robusticity is strongly correlated with increasing age (Henderson et al. 2013). Additionally, degenerative joint disease was observed on the wrists, collarbone, and joints of the rotator cuff (shoulder) and advanced osteoarthritis on the auricular surfaces (hip joints). Joint disorders at the sternoclavicular joint can cause substantial pain and limit the range of motion of the arm (Moravek and Wiater 2017). Considering 
the degenerative changes to the joints of the upper body along with the pronounced entheseal attachments sites, heavy activity could possibly be implied. The severe fracture to the second lumbar vertebra, which obliterated the neural canal, caused a spinal cord injury that likely resulted in impairment of the lower body (Weiss 2013). Thus, it is possible that she used her upper body to compensate for limited function in the lower body. Such an injury is often severely or completely physically disabling without medical intervention. In light of her possible paralysis, we may postulate that she could not have travelled to Skriðuklaustur alone, unassisted, unless she went there seeking treatment for something else (i.e., hydatid disease and tuberculosis) and subsequently experienced the traumatic injury at the monastery.

The frontal and parietal bones presented with reactive lesions, indicative of infectious diseases, such as tuberculosis or treponemal disease, and other bone changes consistent with tuberculosis (See Table 2.1, Ortner 2003). Tuberculosis in humans is caused by infection with Mycobacterium tuberculosis, or other species from the Mycobacterium tuberculosis complex, and primarily spreads between people through the airborne transmission of respiratory droplets, but can also occur through other exposure routes, such as through the consumption of infected material (e.g., contaminated dairy products) (Roberts and Buikstra 2008, Spekker et al. 2020). It is one of the most ancient diseases known to still affect the human population today and recent evidence shows that it was common in the past, even reaching endemic levels in some regions (Zakrzewski 2014, Spekker et al. 2020). Cases of tuberculosis have been observed in the skeletal record from sites occupied as early as the tenth century and may have already become endemic in Iceland by that time (Collins 2019). It remains to be a common disease of poverty today, killing more people every year than any other infectious disease, with nearly a quarter of the world population concurrently affected (Houben and Dodd 2016). Both in the present and the past, tuberculosis has overwhelmingly afflicted the socially marginalised, homeless, and the lower socio-economic class as they tend to face more pathogen exposure due to poor and overcrowded living conditions that generally expose them to immune compromising factors (Zakrzewski 2014). Tuberculosis is debilitating in terms of pain, psychological condition (e.g., headaches and mental changes associated with meningitis), mobility and bodily function (e.g., impairment of the liver and kidneys), and though it can spontaneously resolve in some cases, it is often fatal without treatment (Dye et al. 2009).

\section{Traumatic injury and comorbidities (SKR 130)}

The individual known as SKR 130 was male and he was a middle-aged adult at the time of death. He presented bone changes throughout the skeleton that are indicative of treponemal disease (probable venereal syphilis) according to the criteria described by Hackett (1976) and Ortner (2003). The 
remains display caries sicca on the cranium as well as gummatous lesions and osteitis (bone swelling) on the leg bones (See Table 2.1 and Fig. 2.3, for example), suggesting that he had venereal syphilis. He also had an elevated bone mercury concentration, indicating that he may have received medicinal treatment with it at the monastery, most likely due to his illnesses (Walser III et al. 2019).

Of particular note, however, is the severe fracture to the distal half of the right femur. Femoral fractures primarily occur due to high force impacts, such as may occur during car accidents today, and thus were not very common in the past. Such fractures may have occurred more frequently among older individuals, especially those with advanced osteoporosis or otherwise weakened skeletal systems. Bones become more prone to fracture with increasing age, but other factors, such as pathological processes (e.g., destructive activity from treponemal disease), biomechanical stress, and disorders of the bone metabolism may also increase risks (Matcuk et al. 2016, Cooper et al. 2019). Roberts (2000) notes that individuals exhibiting healed fractures without apposition implies that they received treatment in the form of splinting and limb or bone realignment. The fracture that this individual suffered from healed remarkably well despite the malalignment that shortened the overall length of the leg, which would have resulted in the permanent alteration of the individual's gait and mobility. However, the fracture healed well, and no secondary infection was noted in association with this severe fracture, which indicates that the individual received medical care and assistance for a considerable period of time following the injury until he was able to walk again (e.g., at least 4-12 months). This implies that he may have experienced a temporary period of physical disability, but the question still remains as to whether the individual faced social disability or long-term physical impairment following the healing of the fracture.

\section{Paget's disease of bone (SKR 174)}

The male individual identified as SKR 174 was an older adult (45+) at the time of death. Though the skeleton was incomplete, the recovered skeletal remains had pathological changes indicative of Paget's disease of bone (see e.g., Bhargava and Maki 2010, Whyte 2006), a rare condition influenced by environmental and hereditary factors (See Table 2.1). Clinical research has shown that individuals with Paget's disease of bone involving the tibiae, femora, or acetabular portion of the ilium, such as in the case described here, are statistically likely to experience mobility and functional impairments that may lead to disability (Lyles et al. 1995). Initially the condition is usually asymptomatic, but various signs, symptoms, and complications can occur during the clinical course, such as increased bone fracture rate, osteoarthritis, bone pain, arthropathies, achiness, osteosarcomas, spinal compression or ischemia, muscular atrophy, sensory impairment (e.g., hearing loss), and neurological problems (e.g., headaches/migraines and dementia) 
(Monsell 2004, Whyte 2006, Kimonis et al. 2008). Archaeological cases of Paget's disease of bone often reveal secondary complications, including osteosarcomas, deformity, fractures, and joint disease or osteoarthritis (Mays 2010).

Considering the low ${ }^{87} \mathrm{Sr} /{ }^{86} \mathrm{Sr}$ value $(0.7062)$ determined from a dental enamel sample, he likely had an inland childhood residence (Walser III et al. 2020a). Thus, at some point after childhood he went to Skriðuklaustur, possibly for treatment and/or hospice. The evidence of degenerative joint disease noted on all preserved joint surfaces in the skeleton is likely associated with the individual's advanced age, however, it may have also originated as a secondary complication to the long bone changes arising from Paget's disease of bone. The combination of Pagetic bone changes and degenerative joint disease are likely to have caused notable mobility and functional impairment, which may have been socially disabling. Considering the challenging climate and topography of Iceland, he may have required substantial assistance from other people to have successfully made the journey to Skriðuklaustur.

\section{Conclusion}

In this chapter, the notions of disability in the past have been challenged by emphasising that disabling conditions are always based on the constant entanglement of nature and culture. Nonetheless, such conditions seen in skeletal remains often indicate reduced quality of life for the affected individual, rather than explicitly implicating social disability. All the individuals referred to had severe impairments to deal with during their lives. Some may have been capable of travel to Skriðuklaustur on their own, such as SKR 22, SKR 23, and SKR 174, while SKR 128 and SKR 130 may have not unless their serious impairments only occurred after arrival there. SKR 22 had difficulties with gaining adequate nutrition but had nonetheless survived childhood. He would have required substantial care from his relatives in early childhood, but the aid he gained from the brethren at Skriðuklaustur may have been essential for his survival into his late teenage years. The journey to Skriðuklaustur would have been vastly demanding, requiring assistance, for people suffering from certain conditions, such as paralysis or walking issues caused by limb-length discrepancy (pathologically shortened leg). These journeys would have been especially challenging for those suffering from psychological impairments or illnesses, as may have resulted from some the conditions described in this chapter.

Although evidence of bodily impairment can be detected from skeletal remains, simultaneously indicating conditions that may lead to potential social disability, these identifications may rather provide evidence about medical treatment or care that could improve the quality of their lives in the past. Thus, in this way, while these identifications may answer little about social attitudes and past perspectives on disability, they do nonetheless 
provide indications about life experience and the possible functional limitations these individuals may have faced. In historical overviews, it has on the other hand been underlined that the monastic houses in Iceland did not take care of the sick and poor, since the common people, such as the relatives the sick and invalid, were meant to fulfil these tasks (Guttormsson 2000, p. 101).

The cases from Skriðuklaustur show at least that people had some reason to seek medical care there instead of staying at their relative's residency. The question here is if this was done in the hope for renewed life. All things considered, skeletal data offers clear and useful indications about the care provided to the people that sought treatment at Skriðuklaustur, yet we still cannot explicitly untangle the social perspectives people held about functionally impaired people in the past. It is plausible that they received treatment because they were seen as valued members of society - not in any sense as disabled - that made important contributions to it through renegotiated social roles or occupations. It is though still necessary to consider their presence there as if the monastery was obligated to provide such assistance to the public by the religious mandates of monasticism. Thus, disability lies beneath the surface, in between the lines of impairment and temporal social perspectives.

\section{References}

Battles, H., 2011. Toward Engagement: Exploring the prospects for an integrated anthropology of disability. Explorations in Anthropology, 11 (1), 107-124.

Bethard, J.D., DiGangi, E.A., and Sullivan, L.P., 2017. Attempting to distinguish impairment from disability in the bioarchaeological record: an example from Dearmond Mound (40re12) in east Tennessee. In: J.F. Byrnes and J.L. Muller, ed. Bioarchaeology of Impairment and Disability: Theoretical, Ethnohistorical, and Methodological Perspectives. Springer, 249-267.

Bhargava, P., and Maki, J.H., 2010. "Cotton Wool” appearance of Paget's disease. New England Journal of Medicine, 363 (6), e9. Doi: 10.1056/NEJMicm0912945

Bhattacharya, S., Khanna, V., and Kholi, R., 2009. Cleft lip: the historical perspective. Indian Journal of Plastic Surgery, 42, S4-S8. Doi: 10.4103/0970-0358.57190

Boyd, A. S., et al., 2000. Mercury exposure and cutaneous disease. Journal of the American Academy of Dermatology, 43 (1), 81-90.

Bragg, L., 1994. Disfigurement, disability, and dis-integration in Sturlunga saga. Alvíssmál. 4, 15-32.

Braidotti, R., 2006. Posthuman, all too human: Towards new process ontology. Theory, Culture \& Society, 23 (7-8), 197-208.

Brickley, M., and McKinley, J., 2004. Guidelines to the standards for recording human remains [online]. BABAO/IFA Technical Paper no. 7. Available from: http://www. babao.org.uk/publications/ethics-and-standards [Accessed 17 April 2019].

Callus, I., and Herbrechter, S., 2013. Posthumanism. In: P. Wake and S. Malpas, eds. The Routledge Companion to Critical and Cultural Theory. London: Routledge, 144-153. 
Collins, C. R., 2019. The palaeopathology of maxillary sinusitis, otitis media and mastoiditis in medieval Iceland. Thesis (PhD). University of Reading.

Cooper, C., Heinzle, B., and Reitmaier, T., 2019. Evidence of infectious disease, trauma, disability and deficiency in skeletons from the 19th/20th century correctional facility and asylum «Realta» in Cazis, Switzerland. PLoS ONE 14 (5), e0216483. Doi: 10.1371/journal.pone.0216483

Cross, M., 2007. Accessing the inaccessible: Disability and archaeology. In: T. Insoll, ed. The Archaeology of Identities. London: Routledge, 173-194.

Crozatti, L. L., de Brito, M. H., Lopes, B. N. A., and de Campos, F. P. F., 2015. Atypical behavioral and psychiatric symptoms: Neurosyphilis should always be considered. Autopsy Case Reports 5 (3), 43-47.

Curry, A., 2019. Rare diseases prompted care in ancient times. Science, 363 (6432), 1136. Doi: 10.1126/science.362.6432.1136.

Dye, C., Lönnroth, K., Jaramillo, E., Williams, B. G., and Raviglione, M., 2009. Trends in tuberculosis incidence and their determinants in 134 countries. Bull World Health Organ, 8 (7), 683-91.

Guttormsson, L., 2000. Kristni á Íslandi III. Reykjavík: Alpingi.

Hackett, C. J., 1976. Diagnostic criteria of syphilis, yaws and treponarid (Treponematoses) and of some other diseases in dry bones: for use in osteo-archaeology. Berlin: Springer-Verlag.

Hayles, K., 1999. How we became posthuman. London: The University Chicago Press.

Henderson, C. Y., et al., 2013. Occupational mobility in $18^{\text {th }}$ century rural England: The interpretation of entheseal changes. International Journal of Osteoarchaeology, 23, 197-210.

Hjaltelin, J., 2013. On the use of mercury in syphilis and other diseases. London: Forgotten Books.

Hjaltelin, J., 1868. On the treatment now used against the hydatid disease in Iceland. In: H.C. Lea, ed. The Half yearly abstract of the medical sciences: being a digest of British and Continential medicine and of the progress of medicine and the collateral sciences. Philadelphia: Henry C. Lea, 75-77.

Houben, R. M. G. J., and Dodd, P. J., 2016. The Global Burden of Latent Tuberculosis Infection: A Re-estimation Using Mathematical Modelling. PLoS Med. 13 (10), pe1002152.

Ioannou, S., Sassani, S., Henneberg, M. and Henneberg, R.J. 2016. Diagnosing congenital syphilis using Hutchinson's method: Differentiating between syphilitic, mercurial, and syphilitic-mercurial dental defects. American Journal of Physical Anthropology, 159(4): 617-629. doi: 10.1002/ajpa.22924

Jeffreys D., and Tait J., 2000. Disability, madness and social exclusion in Dynastic Egypt. In: J. Hubert, ed. Madness, disability and social exclusion: The archaeology and anthropology of 'difference'. London: Routledge, 87-95.

Jónsson, M., ed., 2004. Jónsbók. Reykjavík: Mál og Menning.

Kasnitz, D., and Shuttleworth, R.P., 2001. Anthropology and disability studies. In: B. Swadener and L. Rogers, ed. Semiotics and dis/ability: Interrogating categories of difference. New York: SUNY Press, 19-42.

Kimonis, V. E., et.al., 2008. Clinical studies in familial VCP myopathy associated with Paget disease of bone and frontotemporal dementia. American Journal of Medical Genetics, 146A (6), 745-757. 
Knudson, K. J., and Stojanowski, C. M., 2008. New Directions in Bioarchaeology: Recent Contributions to the Study of Human Social Identities. Journal of Archaeological Research, 16, 397-432.

Kosmidis, C., et al., 2018. Management of peritoneal hydatid cysts: A fourty-year experience. Heliyon, 4 (12), e00994. Doi: 10.1016/j.heliyon.2018.e00994

Kristjánsdóttir, S., and Collins, C., 2011. Cases of hydatid disease in medieval Iceland. International Journal of Osteoarchaeology, 21 (4), 479-486. Doi: 10.1002/ oa. 1155

Kristjánsdóttir, S., Larsson, I., and Åsen, P. A., 2014. The Icelandic Medieval Monastic Garden - Did it Exist?. Scandinavian Journal of History, 39 (5), 560-579. Doi: 10.1080/03468755.2014.946534

Kristjánsdóttir, S., 2011. The poisoned arrows of amor: Cases of syphilis from 16th-century Iceland. Scandinavian Journal of History, 36 (4), 406-418.

Kristjánsdóttir, S., 2012. Sagan af klaustrinu á Skriðu. Reykjavík: Sögufélag.

Lyles, K. W., et al., 1995. Functional and mobility impairments associated with Paget's disease of bone. Journal of American Geriatrics Society, 43 (5), 502-506.

Matcuk, George R., et al., 2016. Stress fractures: Pathophysiology, clinical presentation, imaging features, and treatment options. Emergency Radiology, 23 (4), 365-375.

Mays, S., 2010. Archaeological skeletons support a northwest European origin for Paget's disease of bone. Journal of Bone and Mineral Research, 25 (8), 1839-1841.

Meyer, C., et al., 2002. Syphilis 2001 - a palaeopathological reappraisal. HOMO - Journal of Comparative Human Biology, 53 (1), 39-58.

Mitchell, P. D., 2011. Retrospective diagnosis and the use of historical texts for investigating disease in the past. International Journal of Palaeopathology, 1 (2), 81-88.

Monsell, E. M., 2004. The mechanism of hearing loss in Paget's disease of bone. Larygoscope, 114 (4), 598-606.

Moravek Jr., J. E. M., and Wiater, J. M., 2017. Diseases and Conditions: Sternoclavicular joint disorders [online]. Rosemont: American Academy of Orthopaedic Surgeons. Available from: https://orthoinfo.aaos.org/en/diseases-conditions/ sternoclavicular-sc-joint-disorders/ [Accessed 4 November 2020].

Moro, P., and Schantz, P. M., 2009. Echinococcosis: A review. International Journal of Infectious Diseases, 13 (2), 125-133.

Murphy, E., 2000. Developmental defects and disability: the evidence from the Iron Age semi-nomadic peoples of Aymyrlyg, south Siberia. In: J. Hubert, ed. Madness, Disability and Social Exclusion: The archaeology and anthropology of 'difference. London: Routledge, 60-80.

Müldner, G., et al., 2009. Isotopes and individuals: Diet and mobility among the medieval Bishops of Whithorn. Antiquity, 83, 1119-1133.

Ortner, D., 2003. Identification of pathological conditions in human skeletal remains. 2nd ed. Amsterdam: Academic Press.

Rasmussen, K., Skytte, L., Jensen, A., and Boldsen, J., 2015. Comparison of mercury and lead levels in the bones of rural and urban populations in Southern Denmark and Northern Germany during the Middle Ages. Journal of Archaeological Science: Reports, 3, 358-370.

Roberts, C., and Buikstra, J., 2008. The White Plague Continues. In: C. Roberts and J. Buikstra, eds. The Bioarchaeology of Tuberculosis: A Global View On a Reemerging Disease. Gainesville, FL: University Press of Florida, 262-272. 
Roberts, C., and Manchester, K., 2010. The Archaeology of Disease. Gloucestershire: The History Press.

Roberts, C., 1999. Disability in the skeletal record: assumptions, problems, and some examples. Archaeological Review from Cambridge, 15, 79-97.

Roberts, C., 2000. Did they take sugar? The use of skeletal evidence in the study of disability in past populations. In: J. Hubert, ed. Madness, Disability and Social Exclusion: The archaeology and anthropology of 'difference. London: Routledge, $46-59$.

Spekker, O., et al., 2020. Tracking down the White Plague: The skeletal evidence of tuberculous meningitis in the Robert J. Terry Anatomical Skeletal Collection. PLoS ONE 15 (3), e0230418. Doi: 10.1371/journal.pone.0230418

Stirland, A. J., 1997. Care in the Medieval Community. International Journal of Osteoarchaeology, 7, 587-590.

Sugiyama, L. S., 2004. Illness, injury, disability among Shiwiar foragerhorticulturalist: Implications of health-risk buffering for the evolution of human life history. American Journal of Physical Anthropology, 123, 371-389.

Waldron, T., 2007. Hidden or Overlooked? Where are the disadvantaged in the skeletal record?. In: T. Insoll, ed. The Archaeology of Identities. London: Routledge, 193-210.

Walser III, J. W., Kristjánsdóttir, S., Gowland, R., and Desnica, N., 2019. Volcanoes, medicine and monasticism: investigating mercury exposure in medieval Iceland. International Journal of Osteoarchaeology, 29 (1), 48-61.

Walser III, J. W., et al., 2020a. At the world's edge: reconstructing diet and geographic origins in medieval Iceland using isotope and trace element analyses. American Journal of Physical Anthropology, 171, 142-163.

Walser III, J. W., Gowland, R. L., Desnica, N., and Kristjánsdóttir S., $2020 \mathrm{~b}$. Hidden dangers? Investigating the impact of volcanic eruptions and skeletal fluorosis in medieval Iceland. Archaeological and Anthropological Sciences, 12, 77.

Walser III, J. W., 2021. Hidden dangers? An investigation of volcanic and environmental impacts on human health and life in historical Iceland. Thesis (PhD). University of Iceland.

Weiss, J. M., 2010. Spinal cord injury. In: Weiss, L.D., Weiss, J.M. and Pobre, T.,eds. Oxford American Handbook of Physical Medicine and Rehabilitation. New York: Oxford University Press, 305-320.

Whyte, M. P., 2006. Paget's disease of bone. New England Journal of Medicine, 355 (6), 593-600.

Woolgar, C. M., 2006. The senses in late medieval England. US: Yale University Press.

Zakrzewski, S., 2014. Palaeopathology, disability and bodily impairments. In: R. Metcalfe, Cockitt, J. and David R, eds. Palaeopathology in Egypt and Nubia: A century in review. Oxford: Archaeopress, 57-68. 


\title{
3 One Story, One Person \\ The importance of micro/bio research for disability studies
}

\author{
Sigurður Gylfi Magnússon
}

\section{The intellectual development of microhistory}

Microhistory has its beginnings in Italy in the 1970s as microstoria. These scholarly ideas were in the melting-pot for some decades before their influence began to be felt internationally in the 1990s. Microhistory was one aspect of the "cultural turn" in history, which "turned" historian's ideas from the quantitative approach to the qualitative.

Considering the principal characteristics of microhistory there are several aspects which require attention. Some are concerned with the exploration of "history from below" in the English-speaking academic world and "everyday life history" (Alltagsgeschichte) in the German. The intention here is not to trace in detail the reasons why the pioneers of microhistory, such as Carlo Ginzburg started to undertake historic research of this nature. But it should be pointed out that one of the principal reasons was that they felt it was necessary to respond to the French Annales school, and the tradition of history-writing which had evolved there. The Annalistes emphasis on long periods, grand historical narrative, and extensive geographical areas utterly lacked, in the view of Ginzburg and others, any insight into how individuals lived their life from day to day. The approach failed to address the diverse contradictions in the life of every person, their struggles with themselves and the surroundings, both formal and informal. They concluded that this could best be achieved by posing new research agenda and applying new and unconventional methods in answering new historical questions. There is thus nothing surprising in the fact that these two scholarly traditions-microhistory and biography - have been working together in recent years, as individuals in all their variety are the basis of both schools of research.

American historian Guido Ruggiero (1990) points out in his introduction to Sex and Gender in Historical Perspective that the methods of microhistory have mainly been focussed on using the individual increasingly in order to identify major formal changes within society: "At its best, this approach seems to promise a method that will help overcome the depersonalization and abstractness of social history without losing its insights 
on the broader structural factors that condition events. At the least, by portraying how individuals respond to and make decisions in the face of such factors as they perceive them in a concrete historical situation, this perspective provides an important caution on the too easy spinning of the web of modern theory back into the past" (Ruggiero 1990, p. 12).

The emphasis will here be placed upon the individual as a historical phenomenon, working with the concept of "agency" in that context. The concept of "agency" is used here is the same sense as William H. Sewell, Jr. (2005) uses it, maintaining that it is defined as one's ability to have some control over the social settings people are part of, which means that one can affect how these ties develop. They take place within some specific structure which affect people's actions in different ways (Sewell 2005, p. 143-145). While the focus will be on the methods of microhistory, historians' conventional approaches in their research will be discussed, and how they have related to individuals and their attitude to life. For this reason, there will also be discussion of the resources which are the primary candidates for use in applying micro/bio methods in historical research. People on the periphery is the focus of this article.

\section{The individual as a research target}

The place of individuals in research projects is one of the characteristics of the micro historical approach: that is, the relationship between the external conditions of their lives, and the interior lives of those individuals. In all societies individuals live with certain laws and rules. They are also expected to comply with predetermined standards of conduct which have been shaped by traditions, generation after generation. But within every individual is a conflict between diverse desires and wishes; And all of them perceive their personal potential in their own way, often in opposition to accepted tradition and the laws and rules of society. The structure of the society evokes, in other words, a personal response in each individual, and that means that the paths people choose are often utterly at odds with the ones mapped out for them. In research it is important to pay attention to this conflict - and here it is irrelevant whether micro historical methods are applied, or those of biographical research-because it is the key to all changes that take place in society. Without it society would remain in a condition of stasis or perpetual status quo.

It may be important look to the German historian Alf Lüdtke, who explains the position of the individual in his research better than anyone else, with the German word Eigensinn. That word is generally used as a disparaging reference to children's awkwardness or waywardness. Lüdtke applies the word to individuals' personal understanding of all conceivable details of life, and their interpretation of things. The better-off in society often complained of the common people's lack of discipline, alleging that 
the common people would do what they wanted, regardless of anyone else, and would never obey orders.

Geoff Eley (1989) provides an excellent definition of the concept and its use: "The key to Lüdtke's argument is the concept of Eigensinn - an almost untranslatable combination of self-reliance, self-will, and self-respect or the act of reappropriating alienated social relations, particularly at work but also at school, in the street, and in any other contexts externally determined by structures and processes beyond workers own immediate control" (p. 323). The important factor here is that Eigensinn is rarely a conscious action in time and space; instead it is unconscious, and almost always unrelated to the formal institutions of society. Hence the concept embraces that type of human conduct, which is generally regarded as irrational, i.e., at odds with dominant values or received custom. Clearly, this explanation of the concept and Lüdtke's use of it is vastly important, as scholars are always making progress in understanding that the inexplicable factors in people's conduct are a much bigger factor than has hitherto been assumed. Micro historians are likely to be on the lookout for such qualities in people's characterto be expecting behaviours which cannot be foreseen. This "instability in human conduct" - the inexplicable behavioural quirks which are utterly familiar in daily life - may throw a highly significant light upon how ordinary people lived their lives in the past. This use of the concept by Lüdtke may thus have a crucial impact on how scholars who apply the "biographical approach" address their subjects - something which has not been done systematically by traditional biographical researchers.

But what does it mean, that there are certain limits to rationality? Can a history that is not premised on the importance of the rational in human society be expected to end up either in a chaotic postmodern descriptive approach, or as an interminable list of examples? The answer is unequivocal: History should seek out and study the structure of the society, while also demonstrating the scope the individual has within it. The micro historian generally emphasises that it is not only the individual who enjoys a certain freedom within the social structure: The structure itself is in a constant state of evolution and is full of paradoxes which mean that it "open at both ends." The Italian micro historian Givanni Levi (1992) concludes: "This is truly a reversal of perspective in that it accentuates the most minute and localised actions to demonstrate the gaps and spaces which the complex inconsistencies of all systems leave open" (p. 107). But the first step is the presumption that the deeds and desires of individuals do not follow some fixed path: That they are in a constant state of flux, and unpredictable, something which the biographical approach can and should fully recognise.

\section{"The singularization of history"}

The scholarly development which has been traced above - a combination of evolution in the methods of microhistory and the discovery of new source material (egodocuments) (Mascuch, Dekker, and Baggerman 2016, 
p. 11-56, Halldórsdóttir 2007, p. 35-49, Halldórsdóttir 2016, p. 81-100, Magnússon 2015, p. 77-94) - has led to a rejection of the idea that contextualisation is indispensable for historians (Magnússon and Ólafsson 2017, Magnússon and Szijártó 2013). In this the biography has had a great influence on this line of thought, and at the same time it has distanced the present author from other micro historians and their scholarly approach. The above argument leads to the conclusion that the ideas of Hans Render and Binne de Haan that "to understand the whole, we have to understand the parts, but to understand them, we have to understand the whole," will not work (Renders and de Haan 2013, p. 8, Magnússon 2017, p. 42-52). It is argued here that it is important that historians place a strong emphasis on the internal context of the entity being researched, while avoiding the grand narrative. By focussing on the internal context, as is the rule in biographical research, the historian acquires a share in material that would not otherwise be noticed.

The attitude to microhistory of the well-known U.S. historian Jill Lepore's (2001) is a case in point, maintaining that "however singular a person's life may be, the value of examining it lies not in its uniqueness, but in its exemplariness, in how that individual's life serves as an allegory for broader issues affecting the culture as a whole" (p. 133). It is argued here that the value of microhistory lies precisely in the opportunities opened by bringing out the unique aspects of the person and studying it in the subject's own immediate environment. The dialogue between the subject and the environment brings out, exactly, how society really works in people's daily lives. The same principal works for the biographical approach: To approach the subject as something or someone unique, that can open the way to a new understanding of how the society, to which each and every person belongs, works. But this is not possible, unless the scholar rejects the grand narratives, or strives to avoid them as far as possible — and does not have his or her mind on the big picture.

In order to approach the subject as explained above, it is possibly to apply a research model called the "singularization of history" (Magnússon 2003, p. 701-735). ${ }^{1}$ The general idea of the "singularization of history" is based on the following: The model looks inward, and studies all aspects in close detail, bringing out the nuances of the events and phenomena we choose to investigate. The idea is that the focus will always be fixed on the matter in hand and on that alone. The ideology consists in investigating with great precision each and every fragment connected with the matter in hand for which there are sources, and in bringing up for consideration all possible means of interpretation that bear directly upon the material. The main point here is both to study as thoroughly as possible the material directly relating to the subject - to examine every detail exhaustively - and also to strive to bring into the study as much material as possible that relates to the subject, from the immediate environment. Such efforts often open doors to unexpected connections and "voices," which may offer competing explanations of specific aspects of the study. 
One may argue that there are, in fact, two ways to approach any matter: 1) Work outwards, looking for connections to other issues to create a larger synthesis and 2) Work inwards, surveying all corners - leaving no stone unturned - to fill out the "space" that the material at hand takes up. The latter way of doing research is not the most common among historians. On the contrary, historians tend to be preoccupied with the larger context, sacrificing the gain that a detailed analysis might bring to their research. As will be stated later on in this article, the argument will be made for a more intense analysis of the historical sources than historians have grown accustomed to - to deconstruct their context and inner being in as much detail as possible, just as many historians do who deal with the biographical method.

Even if the scale is reduced in the way envisioned here, one must still expect some structural orientation within the frame of reference. But this structure must always be subject to laws other than those imposed by the traditional metanarratives and, because of their scope, must be more malleable - i.e., the frames must be more limited and more easily controlled. What is proposed here is that the essential idea behind microhistory be taken literally: That scholars place the main emphasis on the small research unit and confine themselves largely to that. In this way the opportunity arises to give the full range of voices within society a place in historical research. The singularization of history in this sense provides the researcher with a means of bringing out the contradictions that exist between the different "discourses" of individual groups, and that is a precondition for our being able to approach ideas and points of view that in the general run of events do not come to the fore (Cohen 2019, Magnússon 2010).

\section{Microhistory as a biographical approach}

In the final decades of the twentieth century, biography as a historical method underwent a renaissance in many western countries, especially in the hands of qualified cultural and social historians who took a micro historical approach. ${ }^{2}$ The principal feature of these writings was twofold: Firstly, the increasing recognition of the fragmented nature of historical scholarship has made traditional research, including conventional biographical study, outdated, and out of step with current academic thinking. The response has been clear, mostly leading to those who work with individuals as their main subject now doing so in a new and different manner. In other words, the scholarly trend has worked against the way in which traditional biographers went about doing their business.

Secondly, one thing that has changed is that scholars have introduced biographical subjects of a new kind - members of the society who live on the periphery, who are now studied in highly original and interesting ways. The poets and statesmen - the "greats" - who used to be the primary subjects of biography, were marginalised. Ordinary people who had never done 
anything extraordinary had, nonetheless, left traces behind them. This tended to be because these people had got into trouble with the law, or alternatively because they themselves had written about their ideas and views on life. Material of this nature often proved useful in historical research which took account of the "biographical approach," while also benefiting from the new cultural and social history, seen for instance in the methods of microhistory. What characterises this material is precisely its fragmented nature - sources are few and often difficult to deal with - and that demands that the scholar apply a new approach to the subject. The biography had thus developed into something quite different from the conventional lifestory - although such works retained their popularity on the book market as entertaining reading (Renders and Velman 2020).

The biographical approach gave rise to very interesting experimental adjustments of sources: legal documents were, for instance, deconstructed; Special scrutiny was given to the relationship between those who found themselves on the wrong side of the law and those who were in control of the courts - the complex ways in which power intersected with people's lives. Experiments of this kind went so far that scholars even started to work on lives of people about whom little or no evidence was extant.

It is thus safe to say that the biographical approach evolved towards scholarly experiments which focussed on study of the "self"; How the "self" has evolved and been shaped by diverse factors which are part of people's life and work - gender, nationality, social class, education and so on. Research on the "self" sought to achieve an understanding of the ways people dealt with how they were shaped, in the context of the time. At the same time, the "objective" perspective in historical scholarship, which had predominated throughout the 20th century - the historian's sine qua nonwas increasingly being challenged as a desirable objective, or even a possible perspective. Thus the "subjective" principle gained currency: scholars sought in their works to bring out the individual's experience of life, and of the phenomena being studied. Historians also unhesitatingly stepped into their own text and took their place next to the subject. ${ }^{3}$

\section{The narrative of the "slow" process}

This scholarly research model provides the opportunity to slow down the research process, to examine each fragment of knowledge, and place it in the context of other knowledge possessed by the researcher. In this way many of the best-known findings of micro historians have come into being.

Worth a mention in this context is the "slow" ideology which has appeared in the last 25 years or so and has a contribution to make to this aspect of micro historical studies (Bell and Leong 1998, Levine 1997). "Slowness" calls for creativity: Sensitive, imaginative contemplation of phenomena concerned with people's everyday lives. Slow is the watchword of a range of movements in the arts, architecture, spatial consciousness, and studies 
of time, reflecting individual and collective awareness of quality of life: How to resist the perception of reality which demands quick responses glib and shallow statements, generally based on some momentary instinct: A straight line from A to B, consumption that prioritises speed ("fast food") and maximum calories in the minimum time, spaces providing lowmaintenance comfort and convenience, looks that hides people's soft spots.

The basis of the Slow ideology - like slow violence - is precisely the opposite of this: Not to seek to smooth out people's rough surfaces, but to find opportunities to demonstrate the positive side of the fact that not everything, and everyone, is the same. It is important to give oneself time to consider the qualities of people who have walked a rocky road in their lives, and not the smooth, straight path. Every person's manner and body language has its own qualities which give meaning to life; But these can only be discerned by scrutinising all the details of each subject. This ideology opens up an opportunity for micro historians to examine their subjects minutely, and to discuss them in an enlightened manner. This ideology often leads to such detailed examination of objects and materials on the scholar's desk that the result may be a revelation of something that might be called "slow violence," a behavioural pattern that characterised many societies and was often "hidden" in the language and the mentality of the general public as well as those in power. ${ }^{4}$

There are two reasons why this concept is important: 1) The slow ideology has the advantage to temper the speed of the research; It puts the burden on the scientists' shoulder to look for endless clues in the sources about small and sometimes insignificant everyday life occurrence and 2) Like, slow violence will not be found or located, unless we break away from the traditional dealing with the archive. If the scientist managed to step outside of the regular theoretical focus of scientific research, he or she is likely to find behaviour and action that are not open to the public eye.

Expanding the knowledge of lives of disabled people based on their own perspectives is an unusual opportunity and provides important information for society at large (Stefánsdóttir 2019, Stéfánsdóttir and Traustadóttir 2015, p. 368-380). It is a common knowledge that throughout history people with intellectual disabilities have lacked voice, agency, and control over their lives. Recently they have been acknowledged as valuable contributors to the society at large and the discussion of intellectual disabilities (Walmsley and Johnson 2003). Life stories of people with intellectual disabilities have flourished since the 1990s, especially in the UK (Cooper, 1997, Potts and Fido 1991, Keilty and Woodley, 2013). For example, some significant international anthologies have also been published (Atkinson et al. 2000, Traustadóttir and Johnson 2000, Johnson and Traustadóttir 2005, Walmsley and Jarret 2019, Chapman et al. 2015) where the focus has been on the stories told by the people with intellectual disabilities.

In Iceland biographical and life story work with people with intellectual disabilities is a relatively new research area. Several life stories 
of Icelandic people with intellectual disabilities have been published in international anthologies (Traustadóttir and Johnson 2000, Johnson and Traustadóttir, 2005, Chapman et al. 2015, Walmsley and Jarret, 2019). Some Icelandic life stories have also been published as a part of doctoral theses (Stefánsdóttir 2008, Björnsdóttir 2009). The majority of the life stories mentioned above (international and Icelandic) have been carried out in cooperation between researchers and people with intellectual disabilities. Still, it needs to be kept in mind that autobiographies written by people with intellectual disabilities are rarely found, though with some exceptions (Cooper 1997, Muir 2014, Hreinsdóttir and Stefánsdóttir 2010, Hreiðarsdóttir and Stefánsdóttir 2017). All this scientific approach where the individual is in the forefront is extremely suitable for microhistorical research.

Most of the autobiographies and life stories mentioned above have provided accounts of the many forms of societal discrimination and abuse, often in institutions where the individuals have been subject to inhumane treatment. At the same time the life history can also be a form of resistance, a counter-narrative told in opposition to the dehumanizing conditions and portrayals of people with intellectual disabilities as helpless victims living tragic lives (Atkinson 2004, Mitchell et al. 2006, Stefánsdóttir and Traustadóttir 2015). Many of the life histories give a very reveling account of scientific abuse, how the medical profession dealt with people with disabilities when they had nothing to say about their own conditions and life (Stefánsdóttir 2008). In fact, these stories are among the strongest criticism on modern scientific methods found in the $20^{\text {th }}$ century.

The autobiographical manuscript by Bjargey Kristjánsdóttir (1927-1999), called Bíbí from the farm Berlín in the northwest part of Iceland, that will be dealt with in the next chapter written by Guðrún V. Stefánsdóttir and Sólveig Ólafsdóttir, falls into the above mentioned category of testimonies that come from a person who few payed any attention to, or asked what she wanted to do with her life. She was just told to sit and stand as her gradiences wanted her to behave.

Despite of this all, autobiographies similar to Bíbís, are rarities, both in international settings and in Iceland. Bíbís story is going to provide a unique insights into the lived experience of a person who was marginalized throughout her life, but lived most of her time in a local community in Iceland and had a clear ideas of the life she wanted to live and expressed it in her autobiography. Again, this extraordinary document will be the central feature of the next chapter and I believe that the study of Bíbí will fit well into the conceptual framework I have laid out here in this chapter.

\section{Notes}

1. Sigurður Gylfi Magnússon. (2003) 'The Singularization of History: Social History and Microhistory within the Postmodern State of Knowledge,' Journal of Social History 36, 701-735. The article was republished in an international collection of essays, Historiography: Critical Concepts in Historical 
Studies I-V. Editor Robert M. Burns. London, Routledge, 2006, in vol. IV: Cultural History. The general ideas presented in the Journal of Social History article from 2003 has elicited a powerful response from both Peter N. Stearns and Harvey J. Graff in the Icelandic book: Sigurður Gylfi Magnússon, Sögustríð. Greinar og frásagnir um hugmyndafraði [The History War. Essays and Narratives on Ideology]. Reykjavík: Center for Microhistorical Research, 2007. See Peter N. Stearns, 'Debates About Social History and its Scope,' 17-21 and Harvey J. Graff, 'History's War of the Wor(1)ds,' 475-481. See also: Kristján Mímisson and Sigurður Gylfi Magnússon. 'Singularizing the Past: The History and Archaeology of the Small and Ordinary,' Journal of Social Archaeology 14:2 (2014), 131-156.

2. Much has been written about biography in recent years. Suffice here to refer to an enlightening roundtable in American Historical Review in 2009: AHR Roundtable: Historians and Biography. American Historical Review 114:3 (2009).

3. Also: Gabrielle M. Spiegel. (2007) 'Revising the Past / Revisiting the Present: How Change Happens in Historiography,' History and Theory, Theme Issue 46: Revision in History 46:4, 1-19, which addresses the place of the individual in the postmodern and poststructural academic discourse. Finally, it is important to point out an issue of Rethinking History (2009) which addresses similar issues to those mentioned here. See e.g., Matthew Hollow. (2009). 'Introducing the Historian to History: Autobiographical Performances in Historical Texts,' Rethinking History 13:1, 43-52. I too have stepped into the scholarly text in: Sigurður Gylfi Magnússon. (2007). Sögustríð. Greinar og frásagnir um hugmyndafraði. Reykjavík: Centre for Microhistorical Research.

4. This concept could be compared to direct-, structural- and cultural violence that is sometimes used in disability studies and in social science in general. Recently the concept microagression has gain importance, violence that is a daily phenomenon and occurred over a long period of time - a type of violence that is difficult to pin down and is mostly hidden from the naked eye. See discussions on the concept of slow violence in Sigurður Gylfi Magnússon. Emotional Experience and Microhistory. A life story of a destitute pauper poet in the 19th century. London, Routledge, 2020, 133-139.

\section{References}

Atkinson, D., 2004. Research and empowerment: Involving people with learning difficulties in oral and life history research. Disability \& Society, 19 (7), 691-703. Doi: 10.1080/0968759042000284187

Atkinson, D., McCarthy, M., Walmsley, J., Cooper, M., Rolph, S., and Aspis, R., eds., 2000. Good times, bad times: Women with learning difficulties telling their stories. Kidderminster, UK: BILD.

Bell, M., and Leong, S. T., eds., 1998. Slow Space. New York: Monaccelli Press.

Björnsdóttir, K., 2009. Resisting the reflection: Social participation of young adults with intellectual disabilities. Thesis (PhD). University of Iceland.

Burns, R. M., ed., 2006. Historiography: Critical Concepts in Historical Studies I-V. London, Routledge.

Cohen, T. V., 2019. Roman Tales: A Reader's Guide to the Art of Microhistory. Microhistories. London: Routledge.

Cooper, M., 1997. Mabel Cooper's life story. In: D. Atkinson, M. Jackson, and J. Walmsley, eds. Forgotten lives: Exploring the history of learning disability. Kidderminster, UK: BILD, 21-35. 
Eley, G., 1989. Labor history, social history, Alltagsgeschichte: Experience, culture, and the politics of the everyday-a new direction for German social history?. Journal of Modern History, 61 (2), 297-343.

Graff, H. J., 2007. History's War of the Wor(1)ds. In: S. G. Magnússon, ed. Sögustríð. Greinar og frásagnir um hugmyndafrææi. Reykjavík: Center for Microhistorical Research, 475-481.

Halldórsdóttir, E. H., 2007. Fragments of lives - The use of private letters in historical research. NORA. Nordic Journal of Women's Studies, 15 (1), 35-49. Doi: 10.1080/08038740701253551

Halldórsdóttir, E. H., 2016. A biography of her own: The historical narrative and Sigríður Pálsdóttir (1809-1871). In: T. Kinnumen, M. Leskela-Karki, and T. Possing, eds. Biography, Gender and History: Nordic Perspectives. Turku, FI: Kulttuurihistoria, 81-100.

Hollow, M., 2009. Introducing the historian to history: Autobiographical performances in historical texts. Rethinking History, 13 (1), 43-52. Doi: 10.1080/ 13642520802639629

Hreiðarsdóttir, M., and Stefánsdóttir, G. V., 2017. Ég lifði i pögninni- Lifssaga Maríu P. Hreiðarsdóttur [Life history of María P. Hreiðarsdóttir]. Reykjavík: Bókaútgáfan Draumórar.

Hreinsdóttir, E. E., and Stefánsdóttir, G. V., 2010. Lifssaga brautryðjandans Eyglóar Ebbu Hreinsdóttur [The life history of the pioneer Eygló Ebba Hreinsdóttir]. Reykjavík: Guðrún V. Stefánsdóttir.

Johnson, K., and Traustadóttir, R., eds., 2005. Deinstitutionalization and people with intellectual disabilities: In and out of institutions. London: Jessica Kingsley.

Keilty, T., and Woodley, K., 2013. No going back: Forgotten voices from Prudhoe hospital. Sheffield, UK: The Centre for Welfare Reform.

Lepore, J., 2001. Historians who love too much: Reflections on microhistory and biography. Journal of American History, 88 (1), 129-144. Doi: 10.2307/2674921

Levi, G., 1992. On Microhistory. In: P. Burke, ed. New Perspectives on Historical Writing. University Park, PA: The Pennsylvania State University Press, 93-113.

Levine, R., 1997. A geography of time. The temporal misadventures of a social psychologist, or how every culture keeps time just a little bit differently. New York: Basic Books.

Magnússon, S. G., 2003. The singularization of history: Social history and microhistory within the postmodern state of knowledge. Journal of Social History, 36 (3), 701-735. Doi: 10.1353/jsh.2003.0054

Magnússon, S. G., 2007. Sögustríð. Greinar og frásagnir um hugmyndafraði. Reykjavík: Centre for Microhistorical Research.

Magnússon, S. G., 2010. Wasteland with words. A social history of Iceland. London: Reaktion Books.

Magnússon, S. G., and Szijártó, I. M., 2013. What is microhistory? Theory and practice. London: Routledge.

Magnússon, S. G., 2015. Tales of the unexpected: The "Textual Environment", ego- documents and a nineteenth-century Icelandic love story - An approach in microhistory. Cultural and Social History, 12 (1), 77-94. Doi: 10.2752/147800415X 14135484867180

Magnússon, S. G., and Ólafsson, D., 2017. Minor knowledge and microhistory. Manuscript culture in the nineteenth century. London: Routledge. 
Magnússon, S. G., 2017. The life is never over: Biography as a microhistorical approach. In: Renders, H., De Haan, B., and Harmsma., J., eds. London: Routledge, 42-52.

Magnússon, S. G., 2020. Emotional experience and microhistory. A life story of a destitute pauper poet in the 19th century. London, Routledge.

Mascuch, M., Dekker, R., and Baggerman, A., 2016. Egodocuments and history: A short account of the long durée. The Historian, 78 (1), 11-56. Doi: 10.1111/ hisn. 12080

Mitchell, D., Traustadóttir, R., Chapman, R., Townson, L., Ingham, N., and Ledger, S., eds., 2006. Exploring experiences of advocacy by people with learning disabilities: Testimonies of resistance. London: Jessica Kingsley.

Mímisson, K., and Magnússon, S. G., 2014. Singularizing the past: The history and archaeology of the small and ordinary. Journal of Social Archaeology, 14 (2), 131-156. Doi: 10.1177/1469605314527393

Muir, L., 2014. A whisper past: Childless after eugenic sterilization in Alberta. Canada: Friesen Press.

Nasaw, D., 2009. AHR roundtable: Historians and biography. American Historical Review, 114 (3), 573-578.

Potts, M., and Fido, R., 1991. A fit person to be removed: Personal accounts of life in a mental deficiency institution. Plymouth: Northcote House.

Renders, H., and de Haan, B., 2013. Introduction: The challenges of biography studies. In: H. Render, and B. de Haan, eds. Theoretical discussions of biography. Approaches from history, microhistory, and life writing. Lewiston, New York: The Edwin Mellen Press.

Renders, H., and Velman, D., eds., 2020. Different lives. Global perspectives on biography in public cultures and societies. Leiden NL, Brill.

Ruggiero, G., 1990. Introduction. In: E. Muir and G. Ruggiero, eds., trans. M. A. Gallucci, M. M. Gallucci, and C. C. Gallucci. Sex \& gender in historical perspective. Baltimore: Johns Hopkins University Press.

Sewell, W. H., Jr., 2005. Logics of history: Social theory and social transformation. Chicago: University of Chicago Press.

Spiegel, G. M., 2007. Revising the past/revisiting the present: How change happens in historiography. History and Theory, 46 (4), 1-19. Doi: 10.1111/j.1468- 2303. 2007.00425.x

Stefánsdóttir, G. V., 2019. People with intellectual disabilities in Iceland in the twentieth century: sterilization, social role valorisation, and a "normal life". In: J. Walmsley and S. Jarret, eds. People, policy and practice: Intellectual disabilities in the twentieth century. Bristol: Policy Press, 129-142.

Stefánsdóttir, G. V., 2008. “Ég hef svo mikið að segja” Lifssögur Íslendinga með proskahömlun á 20. öld ["I have so much to say" Life histories of Icelandic people with intellectual disabilities in the 20th century]. Thesis (PhD). University of Iceland.

Stefánsdóttir, G. V., and Traustadóttir, R., (2015). Life histories as counter narratives against dominant and negative stereotypes about people with intellectual disabilities. Disability \& Society, 30 (3), 368-380. Doi: 10.1080/09687599.2015. 1024827

Stearns, P. N., 2007. Debates about social history and its scope. In: S. G. Magnússon, ed. Sögustríð. Greinar og frásagnir um hugmyndafraði [The History War. Essays 
and Narratives on Ideology]. Reykjavík: Center for Microhistorical Research, 17-21.

Traustadóttir, R., and Johnson, K., eds., 2000. Women with intellectual disabilities:Finding a place in the world. London: Jessica Kingsley.

Walmsley, J., and Jarret, S., eds., 2019. Intellectual disability in the twentieth century. Transnational perspectives on people, policy, and practice. Bristol: Policy Press. 


\title{
4 The Peculiar Attitude of the People The life and social conditions of one "feebleminded" girl in the early 20th century
}

\author{
Guðrún V. Stefánsdóttir and Sólveig Ólafsdóttir
}

\section{Introduction}

Bíbí is the nickname of Bjargey Kristjánsdóttir, an Icelandic woman born in 1927 who died in 1999. She grew up on a small farm called Berlin in northern Iceland. After falling seriously ill before her first birthday, Bíbí was labelled "feebleminded" by her family and the local community. In her early years Bíbí was ostracised within the home and hidden from visitors. Bíbí wrote her own autobiography, keeping it secret from her family and neighbours. The autobiography, an enormous work totalling about 120,000 words, evinces intelligence and insight into her life and circumstances.

In this chapter, Bíbí's childhood story is analysed based on two research disciplines: 1) critical disability studies and 2) microhistory. By connecting these two research fields, we will provide a new critical thinking about disability, as well as history. A feminist intersectionality framework is used to analyse Bíbí's childhood story. The primary aim of this chapter is to shed light on the hidden history of people with disabilities, especially, girls in Iceland in the first half of the 20th century and, more specifically, to explore how social class, disability and gender intersected and impacted Bíbís childhood. We also demonstrate how the scientific knowledge and dominant ideology about people with intellectual disabilities influenced and shaped Bíbí's life and circumstances. Then, we reflect on how Bíbí's autobiography appears as a counter narrative that resists negative historical beliefs and stereotypes of people with intellectual disabilities. For this purpose, in addition to Bíbí's autobiography, we use various official records, such as church records, parish registers, and annual reports from her local community. As well as explaining various events in Bíbí's life, these documents also elucidate the spirit of the age and the general state of mind of the people who were part of the community she was brought up in.

\section{Historical background and literature overview}

The history of intellectual disabilities in the 20th century is largely a story of discrimination and social exclusion. In historical public records, people with intellectual disabilities were for the most part presented as abnormal 
and inferior. This is the grand narrative that dominates the history of intellectual disability (Atkinson and Walmsley 1999). In addition, the eugenics movement and the medical understanding of disability have played a crucial role in constructing societal views and stereotypical understandings of people with intellectual disabilities (Carlson 2010, Kevles 1986, Walmsley and Jarret 2019). The eugenics movement argued that "feeblemindedness" was hereditary and "mental defectives" were seen as a threat to society due to their uncontrollable urges and degenerate characteristics (Karlsdóttir 1998, Scheerenberger 1983).

As a result of the medical understanding of disability, people with disabilities have often been characterised as tragic or silent victims: sexless, eternal children, or subjects for doctors' and specialists remedies, such as cure, care, or segregation (Hollomotz 2011). As a consequence of the attitudes described above, it was seen as shameful for parents to have a child with disabilities, lending support to prevailing professional opinions that institutionalisation was in the best interest of all concerned. Despite this, many children grew up with their parents and siblings even though education was not available, nor any other social support or social services (Stefánsdóttir 2008). The first legislation concerning people with intellectual disabilities in Iceland was passed in 1936 (Lög um fávitahæli [1937] 18 445). The Act defined the legal framework for the first Icelandic institution for people with intellectual disabilities. It was later revealed that children and adults were subjected to inhumane treatment and oppressive conditions at the institutions, while education or any other form of meaningful activity was rarely available (Scheerenberger 1983, Stefánsdóttir 2008).

People with intellectual disabilities have lacked voice, authority, and control over their lives. However, since the 1990s there has been an increasing commitment to avert this trend and to engage people with intellectual disabilities in many forms of biographical and life story work (Atkinson 2004, Walmsley and Johnson 2003). The pioneering work of U.S. scholars Edgerton (1967), in listening to the views of people with intellectual disabilities, and Bogdan and Taylor (1982), in giving validity to life stories of the people, paved the way, making significant contributions to changing attitudes and to disability studies. Life stories of people with intellectual disabilities have flourished since the 1990s, especially, in the U.K. (Cooper 1997, Rolph et al. 2005, Potts and Fido 1991, Keilty and Woodley 2013). In recent years, some notable international anthologies have also been published (Atkinson et al. 2000, Traustadóttir and Johnson 2000, Walmsley and Jarret 2019, Chapman et al. 2015).

In Iceland, biographical and life story work with people with intellectual disabilities is a relatively new research area, although several life stories of Icelandic people with intellectual disabilities have been published in international anthologies (Traustadóttir and Johnson 2000, Johnson and Traustadóttir 2005, Walmsley and Jarret 2019). Some Icelandic life stories of people with intellectual disabilities have also been published as part of 
doctoral theses (Stefánsdóttir 2008, Björnsdóttir 2009). Thus, the majority of the life stories mentioned above (international and Icelandic) have been carried out in cooperation between researchers and people with intellectual disabilities. Autobiographies written by people with disabilities, such as Bíbís, are rarely found, although with some exceptions (Burnside 1991, Cooper 1997, Deacon 1974, Hunt 1967, Hreinsdóttir and Stefánsdóttir 2010, Hreiðarsdóttir and Stefánsdóttir 2017, Muir 2014).

Most of the autobiographies and life stories mentioned above have provided accounts of the many forms of societal discrimination and abuse, which often occurred in institutions. At the same time, the life history can also be a form of resistance, a counter-narrative told in opposition to the dehumanising conditions and portrayals of people with intellectual disabilities as helpless victims living tragic lives (Atkinson 2004, Stefánsdóttir and Traustadóttir 2015). Hence, autobiographies similar to Bíbí's are rarities, both in international settings and in Iceland. Bíbí's story provides unique insights into the lived experience of a person who was marginalised throughout her lifetime, but nevertheless spent most of her life in a local community in northern Iceland.

\section{Methodology}

The analysis of Bíbí's autobiography is based on two research disciplines: 1) critical disability studies and 2) microhistory. The general idea behind the latter is explained in this chapter written by Sigurður Gylfi Magnússon in this edited volume. We do not focus on that particular methodology in our chapter. We do, however, introduce its influence on this study as we continue with the analysis of Bíbís autobiography.

\section{Critical disability studies}

The role of critical disability studies in this chapter is to analyse disability as a cultural, historical, social, and political phenomenon (Meekosha and Shuttleworth 2009). Similar to traditional disability studies, we challenge approaches that pathologise physical, mental, and sensory difference as being in need of correction, and instead advocate both accommodation and equality for disabled people in all areas of life. The method is used here both to describe the socio-political constructions of disability and to track the impacts of these constructions on marginalised people like Bíbí. Critical disability studies commonly use intersectional analysis (Campell 2009, Minich 2016). Intersectionality is a concept used to describe and analyse the experiences of marginalised people in terms of multiple factors. As we use the concept, it acknowledges that systems of gender, ability, race, age, and social class intersect and influence wider power relations and personal experiences. From an intersectional perspective, disability is not considered in isolation from other social categories. Thus, it becomes more apparent 
that different social categories and oppressions work together in producing injustice (Collins 2008).

Critical disability studies are significantly aimed toward analysing ableism (Campbell 2009). Ableism, in the context of disability, means that certain physical, cognitive, sensory, or other types of abilities are preferred, and people who have differing abilities are considered impaired and different. Ableism is discrimination on the basis of ability and a network of beliefs, processes and practices that produces a particular kind of self and body projected as the perfect, and, therefore, essential and fully human. Such ableist views have been used to legitimise unequal treatment of disabled people. In ableist societies, disabled people are viewed as less valuable, or even less than human. The eugenics movement of the early 20th century would be considered an example of widespread ableism (Carlson 2010, Campbell 2009).

\section{The source material}

The data used in this chapter are twofold, Bíbís autobiography and public records, such as church records, parish records, and annual reports.

Bíbi's autobiography. It consists of twenty notebooks, amounting to 1,200 pages, written in capital letters - each book around a hundred pages. The autobiography is filled with personal descriptions of her life. The text is very unusual and is mostly written in pencil, and some of the words have been retraced several times as if she was trying to make sure that her story would not be forgotten. The original manuscript is kept in the Manuscript Department of the National and University Library of Iceland, which means that the manuscript is open to the public. In this chapter, the focus will be on her childhood, from birth until her confirmation at the age of fourteen. Bíbí covers that period mostly in the first three parts of her autobiography.

Public records. From the times of the "Mist Hardships" (Móðuharðindi), lasting from 1783 to 1785 , until the first decade of the 20th century, most public supervision was in the hands of clergymen, provosts, district administrative officers, and county magistrates. This can be divided into two domains of authority: that is, spiritual and secular. It is notable that the spiritual authority was responsible for the basic education of the public and preparation for confirmation, the most important ritual of introducing individuals into the community of adults. The secular authority was responsible for providing minimum support for those who did not have the capacity to work and to sustain themselves. Those two components, lack of education that was the basis of confirmation and capacity to work, led to marginalisation.

The records created by the authorities listed above are of diverse origins. They are censuses, church records, parish registers, and annual reports on the state of affairs from subordinates to supervisors, letters of exemptions from confirmation, statements of estates at death and reports of auctions, 
to name but a few. All records reflect their writers. Clergymen, for example, used different language to describe their congregation than the district administrative officers or other authorities. Nevertheless, by systematically analysing, contemporary remarks about individuals with the aforementioned definition of disability in mind, it should be possible to unravel both threads and traces of disabled people in any society.

With the aid of these perspectives - critical disability studies and the methods of microhistory - it has been possible to untangle the threads of Bíbí's life. The main sources originate from the vicar in Hof Parish, both church records and parish registers. Censuses, conducted at ten year intervals, also offer significant insight into the community structure of the period.

\section{Social conditions and important persons in Bíbí's childhood}

Bíbí was born in the village of Hofsós in Hofshreppur municipality. Her parents were Kristján Guðmundsson, farmworker, and Guðrún Steinpórsdóttir, who worked predominately as a housewife and in the fields. The little girl was named Bjargey at a christening ceremony on January 2, 1928 (BÍ. Fell í Sléttuhlíð - prestakall 0000 BA/6-1-1. Prestspjónustubók 1918-1960). In 1929, her parents moved to the cabin known as Berlín, just outside the village, where Bjargey, or Bíbí, was brought up and where she lived into her adult years. Bíbí was commonly identified with the cabin Berlín, although she was not particularly fond of this connection with the farm. The 1910 census contains the first official reference to the small cabin Berlín, stating that Berlín is a turf cabin with one whole timber front and two half-barrel shaped gables. Berlín was less than $15 \mathrm{~m}^{2}$ in total area ('Í́. Manntalið 1910 - Stjórnarráð Íslands - III.). Bíbís descriptions in her autobiography clearly reflect those of official sources, indicating a highly primitive level of comfort with restricted personal space.

In her infancy, Bíbí was considered a promising child, but after falling ill before her first birthday she was classified as "feebleminded" by her family and neighbours and hidden away from strangers. Bíbí shares her recollection of her family's attempts to conceal her existence:

I wasn't allowed to be outside if guests were passing by, which was often in bright sunshine and fine weather. I can tell you a story from the time when I was probably around nine years old. Two girls arrived one morning, one of them was related to me and mum. I cannot recall whether they were offered coffee, but, anyhow, I was the victim of the peculiar attitudes of the people and had to hide in the dark corner by the oven while they stayed. If this peculiar attitude had involved making me go inside when guests arrived or when someone was travelling on the road, it would have been a different thing. But when my father wasn't at home, I could be anywhere I wanted. He was ashamed of me because I was disabled and looked different from other children, that's for sure. 
During Bíbís upbringing and adolescence, social discrimination, and prejudice towards people with disabilities was widespread, especially, if they were considered to be intellectually challenged. It was not uncommon for children and adults with disabilities to be isolated in their homes or concealed, as in Bíbí's case (Stefánsdóttir 2008). In her autobiography, Bíbí often mentions the "peculiar attitude of the people," as she does above, when describing the negative actions or attitudes towards her. Nevertheless, in her story she describes how it was her father who was most ashamed of her and that she was only told to hide in a dark corner when he was at home. By contrast, Bíbí also notes that there was considerable contact between farms and that, as a child, she often went on visits to neighbouring farms. Thus, it would appear that no attempt was made to hide Bíbí away from close neighbours and that when Bíbí talks about "guests" she probably refers to "strangers" who did not know the circumstances in her home.

Although the "peculiar attitude of the people" put its mark on Bíbís childhood and adolescence, she liked living in the country. In her story, she often refers to the Icelandic landscape, revealing her love of nature and her country. She also describes her love for the animals on the farm and how they became her best friends and soulmates, especially, the cats. In her autobiography, Bíbí often refers to the widespread poverty of her youth, although her parents appear to have been neither poorer nor richer than other small farmers in the district. She mentions that a lack of clothes prevented her from being outside and that she often felt cold because she had no warm clothes to wear. But she never mentions hunger or a lack of food. She takes a considerable interest in food and her story presents numerous interesting descriptions of culinary culture and the daily diet, as illustrated by the example below:

At home, our regular diet was blood pudding and milk porridge, milk soup, on rare occasions sweet soup, and rice soup, sometimes bread soup; Twice a week we had meat soup, on Sundays and Wednesdays. Often stew was prepared from leftovers, especially, on Mondays. Otherwise, fish was often on the table, both pan-fried and boiled, fishballs were made from haddock. The stomachs, liver and heads of cod were also eaten. All of this was good food, but the meat soup upset my digestion and always gave me acute diarrhoea.

Bíbí's descriptions of the Berlín family's dietary habits and choices are in line with other contemporary sources. The daily diet was rather simple but changed in step with the seasons and varying success in the fishery, depending on weather conditions. A special effort was made to make thorough use of all organic matter and food scraps (Gísladóttir 1999).

Bíbí describes both positive and negative aspects of her relationships with other children from neighbouring farms. In some cases, she was 
accepted as an equal, but on other occasions she was teased or ignored. Bíbí describes these relationships in her characteristic manner, saying: "My childhood was anything but pleasant; This was because of the people's peculiar attitude; It is wrong of grown-up people when they pretend not to notice that their children are bullying and teasing a person with a disability. That is a nasty attitude to have."

\section{The childhood friends Bíbí and Alda}

Bíbí had one close childhood friend, Alda; they were lifelong friends, and their friendship was of great importance to Bíbí. She dedicates her autobiography to Alda and, at the beginning of her autobiography, she writes:

What made me begin to write this book was that I was talking about my life to my lifelong friend who died this winter. Once when I came to visit her, she approved of the idea and encouraged me to start writing. Therefore, this book is dedicated to her, Alda Kristín Jóhannsdóttir.

Alda was born four years after Bíbí, March 18, 1931, and died in 1989. Her parents were Jóhann Eiríksson, a landlord farmer and fishing operator at Pönglaskáli, and his wife, Sigurlaug Einarsdóttir (P.Í. Manntalið 1930 Hagstofa Íslands 1944). Pönglaskáli was one of the first concrete houses in Hofshreppur district (bÍ. Manntalið 1940 - Hagstofa Íslands 1955). The families of the two friends came from opposite ends of the social ladder. Alda was born and brought up in a concrete house owned by her father who managed his own fishing boat and had people working for him. Bíbí, on the other hand, lived in a small cabin, and her father, Kristján, worked as a day labourer in the village, in both agriculture and fishing.

It was a short distance between Berlín and Pönglaskáli and despite the difference in social status, there appears to have been significant contact between the two families. Below, Bíbí describes her friendship with Alda.

We had similar temperaments, both rather quiet souls, me, and that girl. I got to know Alda better and I don't regret that acquaintance. I liked her, we never quarrelled during those years of friendship, but enjoyed playing together in peace. I felt sorry for Alda and thought she was having a rough time. No doubt Alda also felt I was having a rough time, especially, because of the peculiar attitude of the people. I'm sure it was not the custom at Paunglaskáli to hide Alda away when guests arrived. Alda often came to my home, with her parents' permission. I just hope no one laughs at me when I officially state in this book that I loved Alda as I would have loved my sister if I had had any. We played with my doll and other things. It never occurred to us to try to control each other, this was out of the question. We never slandered anyone, we called nobody names and we didn't tell lies about anyone. We 
just talked about our things and interests. I remember that if I knew Alda was down at Naust, I waited in high expectation, hoping that she would come and visit me; And I was so happy when I saw a fairhaired head appear over the hilltop at Naust farm, then perhaps a red coat appeared and finally all of her. I waited excitedly until she came through the gate between the homefields, and I often stood near the gate until she came to me. This was my Alda, handicapped from birth, but could nevertheless run incredibly fast, considering the circumstances, and she was brave - this was probably what kept her going.

This fragment from Bíbís story bears witness to her warm feelings for Alda and shows how important their friendship was to both of them. According to Bíbí they were close confidantes and their friendship lasted as long as they both lived. As the above piece reveals, Alda had a disability from birth, and this may well have contributed to their mutual understanding and empathy for each other. Bíbí does not indicate the nature of Alda's disability and official documents contain no suggestion that Alda was in any way different from other children. For example, she went to the primary school in Hofsós, whereas Bíbí was not allowed to attend the school (more later). It may be relevant in this context that there was a significant difference in the social status of their parents and Bíbí's words can be interpreted in this direction, when she says ".. it was not the custom at Paunglaskáli to hide Alda away when guests arrived." It can be reasonably inferred that in her relationship with Alda and in the games they played, Bíbí was able to express her true self and escape the role she was often forced into that is, being a disabled child, and a second-class outcast. What these two girls shared as friends was what the historian Barbara Rosenwein (2016) refers to as emotional community. Emotional communities "... are groups - usually but not always social groups - that have their own particular values, modes of feeling, and ways to express those feelings. Like 'speech communities,' they may be very close in practice to other emotional communities of their time, or they may be quite unique and marginal" (Rosenwein 2016, p. 3-4). Bíbí shared this emotional community with Alda.

\section{My brother Steini}

Bíbí had one brother named porsteinn, called Steini. He was born August 26, 1936, when Bíbí was nine years old. Bíbí's feelings towards Steini were mixed, although there is no doubt that she cared for him. She describes him as an inventive and amusingly goofy character, but she also says he was unmanageable, naughty, and mischievous. Bíbí describes in her autobiography that their parents preferred Steini. His status within the family made Bíbí feel wretched and jealous, and she attaches various epithets to the boy, such as "the prince," "the prodigy," and "the oaf." Bíbí argued: 
It was quite incredible how they pampered this boy. Later, I was to look after the little prince, in particular I was supposed to hold his dummy, but I could not keep it up. The backs of my thighs became so sore standing there motionless like some kind of object. It was no better when I was supposed to sit on the floor with the boy; I did that twice but gave up and then she hit me. Mothers should never do such a thing with their disabled child. But I am going to tell you here and now that I would rather have looked after 100 chickens than that little brat.

Bíbí was aware of how her parents felt about Steini and, as a result, she had strong feelings of rejection and inadequacy. As so often in her account, Bíbí hit upon the crux of the matter when she wrote:

They spoilt him rotten, that's for sure. He was a boy, but I was a disabled girl. I know this is not a nice thing to say, but sometimes I felt that all three of them, my parents, and the boy, were like a pack of snarling wolves. You're always in the way, that's how it was with me.

These sentences reveal Bíbís intense pain at being so callously set aside. In her story, Bíbí often brings up how she envied Steini, not only because he received much more attention than she ever did, but also because he was allowed to work outside with her father. Bíbís parents insisted that she help her mother with the typical feminine work inside the farm, whereas Bíbí wanted to work outside in nature. Bíbí and her father constantly argued because of this and, as a consequence, he often hit her or locked her inside the farm. As she describes it: "I was often caned when I protested against washing up or helping mum."

When Bíbí was growing up, the place for women was inside the house, cooking and cleaning and caring for the family. Bíbí did not fall into that category. As described, intersectionality seeks to understand how disability and other social categories, such as gender and social class, intersect and lead to oppression and exclusion (Campell 2009). Bíbí was not only labelled "feebleminded," she was also a girl, and her family was poor and had low social status in the community.

\section{The prominent men in the local community - physicians and clergymen}

\section{Diagnosis and the impact of being stigmatised}

Bíbí was not fond of the medical profession in her early years, as she describes in the autobiography: "In the beginning, when I was young, I was for quite a long time scared of a certain profession; That is, the doctors. I did not want to have anything to do with them, which was not at all surprising." 
Bíbí maintains that she was a promising child. In the summer of 1928, when Bíbí was almost a year old, she lived with her parents at Hofsós. To be able to support the family her father went to work in Siglufjörður, but her mother was hired to work on a nearby farm and took Bíbí with her. Conditions on the farm were grossly inadequate and unhealthy. As a result, Bíbí became seriously ill. She describes the consequences of her illness as follows:

After this, I fell ill and was taken to Siglufjörður for further examination and light therapy. I became so ill that people thought I would die, but those who are least liked live longest. That's how it was with me; It would have been better if I had kicked the bucket then rather than becoming the flotsam and jetsam of this world, if I can put it that way all because of the peculiar attitudes of the people.

Bíbí's narration above reflects her sorrow over having been marginalised and excluded all her life. In the fall of 1937, new developments in Bíbí's struggle with the medical profession came into being, as described in the following passage from her autobiography:

In the fall of 1937, my mother took me urgently to Sauðárkrókur [the nearest town]. The following morning the boat reached Sauðárk rókur. I cannot remember what time it was when we met the doctor, probably around 3 o'clock. I did not like the look of that creature - I apologise to eventual readers for my language! As soon as we entered and I saw him, I lost all control and wanted to have nothing to do with him. This probably happened when I was to be undressed, but anyway the quack inspected me from the top, but not all the way to the toes. Then the churl announced his verdict. I was a wretch in both departments; That is, both mentally and physically, which was a lie. Actually, the bastard announced what was wrong with me. I seem to remember my mother telling him that I was able to read, when he asked. Then he made up the fantasy that I must not eat meat; Instead, I was to eat things I had never tasted before, such as dulse and scurvy-grass. He seemed to think he could put into me what was missing, but he couldn't take it from anyone else, the old scamp. During the night we returned home, but we had hardly entered the house when guests started asking my mother how we had got on. She told them what the old rogue had said, repeating all his bunch of lies. I was furious about this. What I would like to say is this: Never tell guests what is wrong with your child after having taken them to a doctor, least of all if it is something particular.

This detailed description of an incident from the distant past, written in Bíbí's diaries decades after it occurred, is of particular interest. 
Magnússon (2005) points out that memory is closely connected with momentous events in people's lives, both negative and positive. It is probable that this was such an event for Bíbí, one that, in her mind, demonstrated how she had been stigmatised as deviant and second class. Bíbís description reflects her attitude to the highly negative stigma of disability, which she regards as a label that leads to exclusion and negative attitudes. This is, especially, noticeable in the way Bíbí was deeply hurt by her mother telling others about the doctor's diagnosis.

In the Sauðárkrókur physician's report to the Directorate of Health for the year 1937, the main diseases occurring in his area are listed under their Latin names, one of which was "Poliomyelit," or polio (Latin: Poliomyelitis). The doctor diagnosed one patient as having this disease; this patient was probably Bíbí (bí. Skjalasafn Landlæknis. Skýrslu héraðslækna fyrir árið 1937). When the pastor conducted his regular pastoral inspection in Berlín in 1936, a year before the visit to the doctor in Sauðárkrókur, he wrote in the comment's column that Bíbí was suffering from rickets (Latin: Rachitis). Bíbí describes the attempts by doctors and the clergyman to diagnose her illness in the following terms:

My mother had taken me to them all, but to tell the truth, I cannot remember any of them. One thing, I remember, though; Each said his own piece of nonsense. One said I had rickets, which was nonsense. Another said I had swollen glands behind the stomach; This was also nonsense. Kids who have this, grow naturally and it has no effect on them. I know this well now.

Bíbí was probably right in the above assessment. At a later stage in her life Bíbí was diagnosed with hypothyroidism, which probably afflicted her from early age. This ailment can display a number of symptoms, varying from fatigue and constipation to curtailed growth and intelligence. To prevent this condition, all neonates have for a long time been screened for this particular disease, which has virtually been eradicated in almost every developed country (Roberts and Ladenson 2004). The symptoms outlined here are often referred to in Bíbís autobiography when she describes herself and her "sickliness," as she puts it. Moreover, she tells us that she was often tired and that her growth was not normal.

Bíbí does not explain why her mother, Guðrún, took her to Sauðárk rókur to consult the local family doctor. This may well have been mainly because Bíbí's mother wanted the opinions of another physician. In 1937, however, the year they visited the physician in Sauðarkrókur, there was also a doctor available in Hofsós. Although we cannot be sure, it is possible that Bíbís parents felt that Hofsós was too close and that the shame attached to having a disabled child played a major role in the decision. 


\section{Education and the reading lessons}

In 1907, Iceland adopted the first legislation on general education (Lög um fræðslu barna [1907] 59 A 128). The law stipulated compulsory education for children 10-14 years of age. Other aspects of children's education were assigned to the home and children were supposed to come to school more or less able to read and write. This requirement to teach children at home was based on the centuries-old domestic education system where the pastor acted as supervisor and examiner. Although the final examinations that were part of the compulsory education system had taken over the educational assessment that had previously been part of the confirmation, clergymen nevertheless continued to test children's abilities in reading, writing, arithmetic, and biblical knowledge well into the first decades of the 20th century. It is worth mentioning that in Hofsós in 1938, children were taught in an old school building with one classroom and in the basement of the local community centre (Anon 1938). Despite the legal obligation to provide compulsory education, the law also specified that children could be exempted from attending school due to "lack of intelligence" or illness. We cannot say for sure why Bíbí did not have the opportunity to go to school, but this legal exemption may well have played a role. Bíbí describes her feelings on this as follows:

I have felt so sorry, deep down within myself, not to be allowed to go to school with my peers. But what of that. There are probably few things that peculiar attitudes cannot spoil. In those days when I was ten years old, all my age peers had to go to primary school, but I was not allowed to go to school, instead they got a girl to teach me after dad had tried.

This reference also bears witness to the "peculiar attitude of the people," the negative perspectives that dominated the community in those times, and also demonstrates how much it hurt Bíbí's feelings to be denied the opportunities of her peers. Nevertheless, Bíbí's father was keen to ensure that she was taught at home; this instruction was carried out by various people, such as her father himself, her grandmother, and girls from neighbouring farms, as Bíbí mentions above. Things did not always go smoothly, however, as Bíbí recounts in her autobiography. The struggle with her father she describes in the following manner:

Sometimes the old codger, my dad, lost his patience, and told me off while teaching me to read. Once he slapped me in the face with the alphabet book. Nobody should do a thing like that, least of all hit a weak, disabled child. My granny was a more patient teacher than my dad. Later, they got a girl to teach me. Her name was Guðríður and she 
made me read the book of bedtime stories which aunt Jane had sent me. I could probably read by that time. I never went to primary school but took the spring exam and answered questions.

The church records show that when the pastor came to inspect the home at Berlín in 1936, Bíbí was nine years of age; she knew the letters of the alphabet and was able to read simple words. Two years later, another pastor had taken over and he gave Bíbí the following grades: Christianity v, reading v+, arithmetic v. Here, $\mathrm{v}$ - indicates "good," which is worse than "excellent," but better than "poor." An additional comment accompanies Bíbí's entry: That is, the statement "backward" (DÍ. Fell í Sléttuhlíð - prestakall 0000 BA/6-1-1. Prestspjónustubók 1918 - 1960). This comment probably originates from Bíbí's parents because the year before, in 1937, Bíbí's mother, Guðrún, had taken her on the consequential visit to the physician in Sauðárkrókur.

\section{The confirmation}

With the Reformation in Iceland, it became the duty of pastors to test their parishioners' knowledge of Christianity. This role became more comprehensive as the centuries went by, gradually expanding to include all general education of children in reading, writing, and finally arithmetic. This educational career was completed with the children's confirmation, after which they were regarded as adults at the age of 14. Certain conditions needed to be fulfilled to be confirmed, the most important of which were having been christened and learnt the necessary subject matter and being fully 14 years of age (Arnórsson 1912). Although the law on children's education implemented at the beginning of the 20th century relieved the clergymen of some of the above duties, the old traditions nevertheless remained strong. The confirmation was, in other words, a big event in Bíbí's youth and seen as a ticket into adult life.

On July 8, 1941, Bíbí was confirmed in the local church of Hofskirkja and the clergyman wrote in the church record that both her knowledge and conduct were "Excellent" (DÍ. Fell in Sléttuhlíð parish 0000 BA/6-1-1. Church register 1918-1960). It is of particular interest, however, that Bíbí was confirmed alone and her age peers, eight boys and three girls, had been confirmed together at least a month earlier, on Whit Monday (bÍ. Fell í Sléttuhlíð - prestakall 0000 BA/6-1-1. Prestspjónustubók 1918-1960).

Based on Bíbi's autobiography, there appears to be no doubt as to whether or not she was to be confirmed. Although she did not attend school with her peers, she began confirmation preparations with them when she was 13 years old. It would appear that right up to her confirmation day, Bíbí and her family thought she was going to be confirmed with her peers. It was, therefore, a bitter disappointment to her when she was excluded. In 
her autobiography, Bíbí tells us that her mother went to Siglufjörður to buy clothes for the confirmation, and she describes the day when her peers were confirmed in the following manner:

Yes, if only it could have been like that. On Whitsun morning I of course wanted to join my peers. Mum started dressing me in the fine trousers and the suspender belt. Then my old daddy urgently had to go to the village before noon and when he returned, he said he had spoken to two honourable gentlemen; They were the Reverend Guðmundur and Bragi, the district doctor. He said he had asked both of them whether they thought I was fit to go to a certain ceremony with my peers and apparently the pastor said "yes," but the doctor said "no" and his opinion decided the matter. This was the news my old dad brought back. In those days it never occurred to me to be suspicious of anyone. I was upset to miss going to the church and not being able to join my peers and I started to cry. Everything was ready; Sigurlaug á Pönglaskála had done my hair and Anna Páls had set it in waves.

One can easily imagine the young girl's shock, helplessness, and disappointment. Bíbí also indicates in her story that when she was eventually confirmed alone, a few weeks later, she was not impressed by the ceremony; no doubt prior events played a major role in her evaluation.

At first, Bíbí probably thought that the reason for the sequence of events on the confirmation day was that she had been ill with a cold a few days earlier, although she had recovered on the actual day when the confirmation was to take place. But later, Bíbí realised that the real reason was different and once again she blamed the "peculiar attitude of the people," or the negative mentality of the time, which had so often spoilt her childhood and would continue to do so for the rest of her life.

\section{Interpretation and concluding remarks}

Bíbí's autobiography clearly reflects the influence of the grand narrative of eugenics and the medical understanding of disability (Kevles 1986, Walmsley and Jarret 2019). As a result, Bíbí was marginalised and experienced many forms of exclusion and oppression. Bíbí was definitely unaware, as were other members of the community in those times, of the impact of eugenics and medical science upon negative attitudes towards her. She blames the "peculiar attitude of the people," not her impairment, for her problems and wretched circumstances. It could be maintained that Bíbís understanding of disability was opposed to the traditional medical understanding, where all problems are seen in terms of the impairment of the individual (Goodley 2016). Blaming the present state of mind of the general public reveals the modern social understanding of 
disability. Critical disability studies note that disability only becomes a barrier because of society's negative attitudes and responses (Meekosha and Shuttleworth 2009). Bíbí did not fit into the ableist vision of society and these views were used to justify her unequal treatment and isolation. In Bíbís case, the negative attitudes of her family and the local community became the largest hindrances in her life.

As described in this chapter, intersectionality theories were used to analyse Bíbís childhood story. Thus, it becomes more apparent that different social categories, such as disability, gender, social class, and oppression, combine in producing injustice (CollinsIn 2008). The examples from Bíbí's story presented in this chapter clearly reveal how those three social categories - that is, disability, social class, and gender - intersect in Bíbís life and lead to multiple forms of oppression and exclusion in her life. An example of the way gender and disability intersect in Bíbís childhood is how her brother Steini was preferred to her, as she points out, because she was a "disabled girl," and he was a boy. Bíbís parents were poor farmers, and her story contains numerous examples of the way her disability and social class intersects. A clear case in point is the difference in social position of Bíbí and her friend Alda, both of whom had disabilities. Alda's parents were, however, positioned considerably higher on the social ladder than Bíbís parents. Thus, it becomes more apparent that different social categories and forms of oppression work together in producing multiple layers of discrimination and oppression in Bíbís life (Campbell 2009).

The main theme in the examples from Bíbís childhood are the exclusion and humiliation she was subjected to. She also includes examples of how she protested and challenged people when she felt she was unfairly treated. Those protests were not always loud; They frequently occurred in her mind, as demonstrated by the text of her autobiography. Although the examples from Bíbí's autobiography reveal the injustice she had to live with, they also strongly reflect Bíbí's personality; She was a humourist, a great lover of nature and animals, and, in many respects, her way of life resembled that of other country children. Bíbí shows us that the longings and expectations of the little girl are the same as those of her peers early in the early 20 th century, which first and foremost involved the comforting presence of family and loved ones, safe shelter, having friends and being involved and accepted by one's family and the local community.

To further clarify Bíbí's childhood, various contemporary sources were used where her name occurs, such as church records, parish registers, and annual reports. As well as revealing various occurrences in Bíbís life, these sources also cast light up the spirit and social attitudes of the times when she was growing up. Bíbís own story, however, often provides a totally different perspective and, in some instances, appears as a counter-narrative to the dominant official attitudes, as so clearly demonstrated by her confrontation with the medical profession. By integrating these methodologies, as we did in this chapter, building on critical disability studies and microhistory, 
we hope to create a new and critical way to analyse personal stories. By presenting Bíbís autobiography as a counter narrative against the attitudes that characterise the dominant ideology of the period of Bíbís childhood and youth, and the way she is depicted in contemporary official sources, the grand narrative is challenged and exposed. The focus of such an approach is always on the individual and his or her relationship with the near environment in each instance. Thus, our presentation of the past is expanded and enriched by the smallest details, as Bíbís autobiography shows us in its exceptional clarity and detail.

\section{References}

\section{Archives}

Pjóðskjalasafn Íslands. PÍ. (National Archives of Iceland)

pí. Fasteignamat 1916-1918 - undirmat; Skagafjarðarsýsla

pÍ. Manntalið 1910 - Stjórnarráð Íslands - III. skrifstofa 1914 A/105-1-1. Hof á Höfðaströnd.

DÍ. Manntalið 1930 - Hagstofa Íslands 1944 A/20-1-1. Skagafjarðarsýsla II og Eyjafjarðarsýsla I.

pÍ. Manntalið 1940 -Hagstofa Íslands 1955 A/32-1-1. Skagafjarðarsýsla.

bÍ. Skjalasafn Landlæknis. Skýrslur héraðslækna fyrir árið 1937.

pÍ. Fell í Sléttuhlíð - prestakall 0000 BA/6-1-1. Prestspjónustubók 1918-1960.

Anon., 1938. Skólabyggingar í sveitum. Menntamál, 43-44.

Arnórsson, E., 1912. Íslenskur kirkjuréttur [Icelandic ecclesiastical law]. Reykjavík: Published at author's expense.

Atkinson, D., 2004. Research and empowerment: Involving people with learning difficulties in oral and life history research. Disability \& Society, 19 (7), 691-703.

Atkinson, D., et al., ed., 2000. Good times, bad times: Women with learning difficulties telling their stories. Kidderminster, UK: BILD.

Atkinson, D., and Walmsley, J., 1999. Using autobiographical approaches with people with learning difficulties. Disability and Society, 21 (2), 203-216.

Björnsdóttir, K., 2009. Resisting the reflection: Social participation of young adults with intellectual disabilities. Thesis (PhD). University of Iceland.

Bogdan, R., and Taylor, S.J., 1982. Inside out: The social meaning of mental retardation. Toronto: University of Toronto Press.

Burnside, M., 1991. My life story. Halifax, CA: Pecket Well College.

Carlson, L., 2010. The faces of intellectual disability: Philosophical reflections. Bloomington: Indiana University Press.

Chapman, R., Ledger, S., Townson, L., and Docherty, D., ed., 2015. Sexuality and relationships in the lives of people with intellectual disabilities. London and Philadelphia: Jessica Kingsley.

Campbell, F., 2009. Contours of ableism: The production of disability and abledness. New York: Palgrave Macmillan.

Cooper, M., 1997. Mabel Cooper's life story. In: D. Atkinson, M. Jackson, and J. Walmsley, eds. Forgotten lives: Exploring the history of learning disability. Kidderminster, UK: BILD, 21-35. 
Collins, P.H., 2008. Black feminist thought: Knowledge, consciousness, and the politics of empowerment. London: Taylor Francis Ltd.

Deacon, J., 1974. Tongue tied. London: National Society for Mentally Handicapped Children.

Edgerton, R., 1967. The cloak of competence. Berkeley: University of California Press.

Gísladóttir, H., 1999. Íslensk Matarhefð. Reykjavík: Mál og Menning.

Goodley, D. 2016. Disability studies. An interdisciplinary introduction. Sage.

Hollomotz, A., 2011. Learning difficulties and sexual vulnerability: A social approach. London and Philadelphia: Jessica Kingsley.

Hreinsdóttir, E.E., and Stefánsdóttir, G.V., 2010. Lifssaga brautrydjandans Eyglóar Ebbu Hreinsdóttur [The life history of the pioneer Eygló Ebba Hreinsdóttir]. Reykjavík: Guðrún V. Stefánsdóttir.

Hreiðarsdóttir, M., and Stefánsdóttir, G.V., 2017. Ég lifði i pögninni - Lífssaga Maríu P. Hreiðarsdóttur [Life history of María P. Hreiðarsdóttir]. Reykjavík: Bókaútgáfan Draumórar.

Hunt, N., 1967. The world of Nigel Hunt. Beaconsfield, UK: Darwen Finlayson.

Johnson, K., and Traustadóttir, R., ed., 2005. Deinstitutionalization and people with intellectual disabilities: In and out of institutions. London: Jessica Kingsley.

Karlsdóttir, U.B., 1998. Mannkynbatur: Hugmyndir um batta kynstofna hérlendis og erlendisá 19. og 20. öld. Reykjavík: University Press.

Keilty,T., and Woodley, K., 2013. No going back: Forgotten voices from Prudhoe hospital. North of England: The Centre for Welfare Reform.

Kevles, J., 1986. In the name of eugenics. London: Pelican.

Lög um fræðslu barna [Law on education for children]. [1907] 59 A 128

Lög um fávitahæli [Law on Sanctuaries]. [1936] 18445

Magnússon, S.G., 2005. Sjálfssögur: Minni, minningar og saga. Reykjavík: Háskólaútgáfan.

Meekosha, H., and Shuttleworth, R., 2009. What's so 'critical' about critical disability studies?. Australian Journal of Human Rights, 19 (1), 47-75. Doi: 10.1080/ 1323238X.2009.11910861

Minich. J.A., 2016. Enabling whom? Critical disability studies now. Lateral Jornal of the Cultural Studies Association, 5 (1). Doi: https://doi.org/10.25158/L5.1.9

Muir, L., 2014. A whisper past: Childless after eugenic steilization in Alberta. Canada: Friesen Press.

Potts, M., and Fido, R., 1991. A fit person to be removed: Personal accounts of life in a mental deficiency institution. Plymouth, UK: Northcote House.

Roberts, C.G., and Ladenson, P.W., 2004. Hypothyroidism. The Lancet, 9411 (363), 793-803.

Rolph, S. 2002. Reclaming the past. Milton Keynes: The Open University.

Rosenwein, B., 2016. Generations of feeling. A history of emotions 600-1700. Cambridge: Cambridge University Press.

Scheerenberger, R.C., 1983. A history of mental retardation. Baltimore, MD: Paul H. Brookes.

Stefánsdóttir, G.V., and Traustadóttir, R., 2015. Life histories as counter narratives against dominant and negative stereotypes about people with intellectual disabilities. Disability \& Society, 30 (3), 368-380. Doi: 10.1080/ 09687599.2015 .1024827 
Stefánsdóttir, G.V., 2008. 'Ég hef svo mikið að segja' Lifssögur Íslending með proskahömlun á 20. öld ["I have so much to say" Life histories of Icelandic people with intellectual disabilities in the 20th century]. Thesis (PhD). University of Iceland.

Traustadóttir, R., and Johnson, K., ed., 2000. Women with intellectual disabilities: Finding a place in the world. London: Jessica Kingsley.

Walmsley, J., and Johnson, K., 2003. Inclusive research with people with learning disabilities. London: Jessica Kingsley.

Walmsley, J., and Jarret, S., ed., 2019. Intellectual disability in the twentieth century. Transnational perspectives on people, policy, and practice. Bristol: Policy Press. 


\title{
5 From a Life With a Different Body to a Recreated Folklore of Accentuated Difference
}

\section{Sigríður Benediksdóttir versus Stutta-Sigga}

\author{
Eva Pórdís Ebenezersdóttir and \\ Sólveig Ólafsdóttir
}

\section{Introduction}

People who are considered physically and/or mentally different often become the object of gossip. Gossip, in turn, are narratives of both a lived experience of difference and a living tradition of tales of difference. As stories are what combines our fields of folklore and history we work with a narrative approach to disability. Tanya Titchkosky and Rod Michalko are two scholars who have given rise to a narrative understanding of disability as they claim that a disability and a disability understanding is not only portrayed in stories but also formed and shaped by them (Michalko and Titchkosky, 2020, Titchkosky and Michalko 2014, Titchkosky 2002, 2009, 2007, Michalko 2017, 2002). By combining disability studies, microhistory, and folkloristics this chapter aims to follow up on two main questions: First, to build a "life-thread" from official records of an individual who doubtlessly experienced being different and secondly to see how and why gossip about that person was created and recreated through time, affecting the social memory about this person. From an extended list of people who fit these criteria of being in both the historical and the folkloric records we chose Sigríður Benediktsdóttir (nicknamed Stutta-Sigga or Short-Sigga), child minder and storyteller (1815-1900), as her life is well documented in official sources and thus allows for a detailed contextualisation and analysis.

The examined source material is taken from both the historical documents produced during Sigríður's lifetime, and different kinds of printed legends and newspaper items that were collected, recorded, and printed in the 19th and 20th century, as well as a photograph of Sigríður. According to the source material Sigríður had physical, as well as cognitive or mental differences which prompted the creation and the spread of legends and gossip about her personality and bodily constitution. It is our intention to showcase Sigríður as an individual, applying a method that combines 
different genres of stories revealing how disability is formed in narratives. The aim is to review vastly complex public records and later legends that are full of gaps. Together they form an illusion of a continuous story thread that outlines Sigríður's life and her role as a character in the legends, that can be interpreted as representation of a disability understanding at the time of narration both in life and legend.

Our goal is to tell the stories about Sigríour from the perspectives of history and folklore, and thereby the reader on a narrative journey, from a life with a different body to a recreated folklore of accentuated difference. In the end, we will attempt to set all the complicated and contradictory stories of Sigríður Benediktsdóttir into a new context with ourselves through photographs, telling a new recreated story of Sigríður's life and legends. When working with personal stories of people that are long dead and consent and participation is not possible there is little or no established ethical regulation that we are expected to uphold (Fogel et al. 2010, p. 91-94, McKee and Porter 2012, p. 66-68, Wilkinson 2002, p. 38-39). We ground our research on what Cresswell calls an advocacy/participatory worldview in research design. Such approach intends to reform and change the lives of both the informants and researchers by addressing important social issues such as inequality, oppression, domination, suppression, and alienation (Cresswell 2009, p. 9-10). As we work with the stories of Sigríður as an individual and her life and stories as a contribution to the research, we draw out the injustice imbedded in the stories and retell them from a point of empowerment. By our recreation of the narrative, we change, not her life, but her story and our own understanding of it. With this mindset towards Sigríður, we also nod in the direction of collaborative history and its high ethical standard, where people with intellectual disabilities participate in research through their own oral history, public records, and social memory, focusing on recent past which the living remember and can collaborate on (Atkinson and Walmsley 2010, p. 280-282). Building on advocacy and participatory research design our research and writing is anchored in respect, justice, integrity, ethical decision making, and the code of conduct implemented through collaborative history as if Sigríður were a living partaker in the research.

\section{Historical and folkloric sources}

Until the first decade of the 20th century, public supervision was in the hands of clergymen, provosts, district administrative officers, and county magistrates. While the clergy was responsible for the basic education of the public and the preparation for confirmation, the secular authority was responsible for providing minimum support for those who did not have the capacity to work and to sustain themselves. Lack of those two factors, the education that was the basis of confirmation and the capacity to work, led to marginalisation. 
The records created by the authorities are, in Sigríður's case, church records, parish registers, and county records. In the records, the supervisor in question wrote what Sólveig Ólafsdóttir names "claims," which are systematic comments found in parish registers, church books, or local commune accounts and other public records about the subject in question. By systematically analysing contemporary remarks about Sigríður we can spin her "life-thread." The methodology of life-threads is a method to review vastly complex public records full of gaps and combine them into one continuous thread - a life-span - that outlines the steady or defined points of life for a person.

The synthesis of the life-thread of Sigríður will then be compared to legendary stories and folktales about Stutta-Sigga, as she is always referred to in the legends. Although legends usually sound truthful, they are not historical truths and can quite often have little to no actual truth to them. However, even if legends are not true as such, they do reflect a certain social truth as they mirror people's ideas, beliefs, and attitudes about culture, society, and nature. Legend events can be rooted in a time long before the legends are narrated or written, but it is the time and context of narration that is visible in the social mirror of legends (Tangherlini 1994, p. 15-22, Dégh 2001, p. 23-27, Oring 2008, p. 129-131). Legends of Sigríður were collected and printed in the 20th century and are accessible in books, archives of folklore and newspapers. Each narrative is textually and contextually analysed to draw forth a social mirroring in the legend (Hufford 2003, p. 152-155, Latvala and Laurén 2013, p. 251-254).

As the legends partially reflect Sigríður's life-thread, she was likely subjected to gossip in her lifetime. A few decades after Sigríður's death, the gossip shifts from oral tradition to paper and the traceable recreation of the legends begins. Gossip can, via retelling, develop into more structured stories that spread through society and often circulate from tale to experience and back to the tale (Honko 1964, p. 103-105, Dégh and Vázsonyi 1974, p 227-229). Many such stories finally disappear when new and noteworthy people or situations arise. Some, however, live on through generations and get a firmer footing, and the stories about Stutta-Sigga are an example of this. When her stories were written down, forty years after her death, they had survived at least one, if not two generations of storytelling. The process of writing and publishing undoubtedly fixed them in the structured legend form we find in the first publication in $1940^{2}$.

The last set of sources we make use of are two photographs of Sigríður, both taken late in her life. One has been widely used and is archived in Iceland's National Museum, the other is kept in the local museum at Akureyri and despite being accessible from there seems not to have been used in any publication. As photographs are a form of narrative the context of these photos and their use through time is an important part of the narrative journey. The photo of Sigríður is also the closest we can get to include herself in the research and to form a connection to her we step into 
her photograph by taking a new image of where we mirror her stances and our own embodied experiences (see Figs. 5.1, 5.2, 5.3). Working with photographs and the analysis of them is also an example of source material that combines our two fields as both history and folkloristics have methodological traditions for using photographs.

\section{Sigríour in life}

Sigríður Benediktsdóttir was born on December 18th, 1815, on the farm Flögusel in the parish of Myrká in North Iceland. Her parents were Benedikt Sigfússon, farmer at Flögusel and his wife Rósa Oddsdóttir (Myrká in Hörgárdalur parish, n.d. BA/3-1-1). They had many children and, in the census of 1816 the year after Sigríður was born, nine of them were recorded, of which she was the youngest (The national archives of Iceland, n.d.). Sigríður lived in Flögusel until her mother died in 1845. The priest of the parish did not think highly of the family, calling them "invalid paupers" ${ }^{3}$ and said that that their home was "rather unkempt." He wrote the following claims

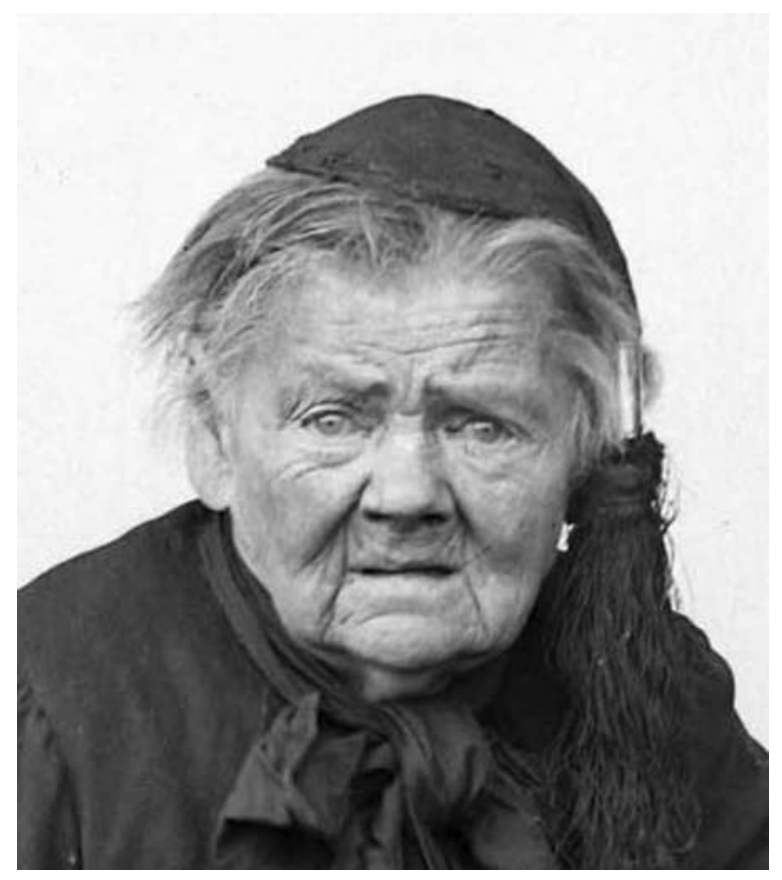

Figure 5.1 A small portrait of Sigríður Benendiktsdóttir face and shoulders wearing her Sunday best outfit. The "passport" style image is cropped from Figure 5.2. It is difficult to determine if Sigríður is looking thoughtfully into the camera as her eyes are puckered. She has a high forehead, broad nose, and deep lines around the mouth. 


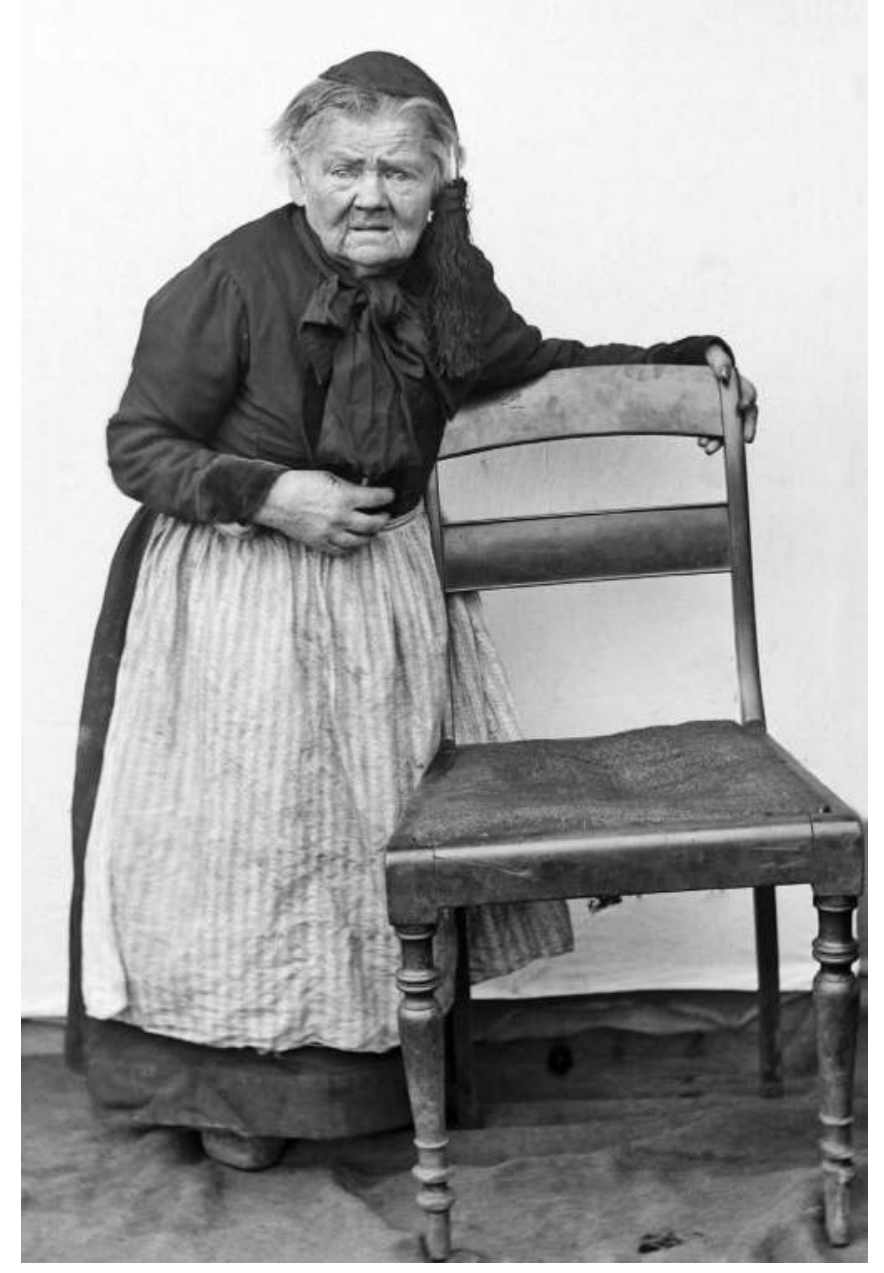

Figure 5.2 Sigríður is in her finest sweater/jacket, with a dark cravat, a clean apron, and a cap with tassel. This is a woman in her very best clothing. It is never claimed that the photo was taken at the birthday party, but she would undoubtedly have worn the same, or a similar outfit on that occasion as most women had one set of fine clothing. She stands by a chair and is stooping slightly. She has her left hand around the chair, grabbing it as if to support the unsteady chair, rather than to support herself. The right hand, showing signs of labour, rests on her apron string. She looks towards the viewer so that we look directly in her face, but the gaze is uneasy and past the lens, the photographer, and the viewer. The social context in 1940, mentioning the photo and the birthday, builds a strong element of credibility for the birthday legend, as well as the legend cluster, since the photo proves Sigga's existence. The photo was, however, not printed with the legends until 1948, in Hjartaásinn. In the many reprints and reproductions that followed the mention of the photograph is often taken out of the birthday party context, or completely omitted.

Sources: Kona, peysuföt. STÆ2-282. 


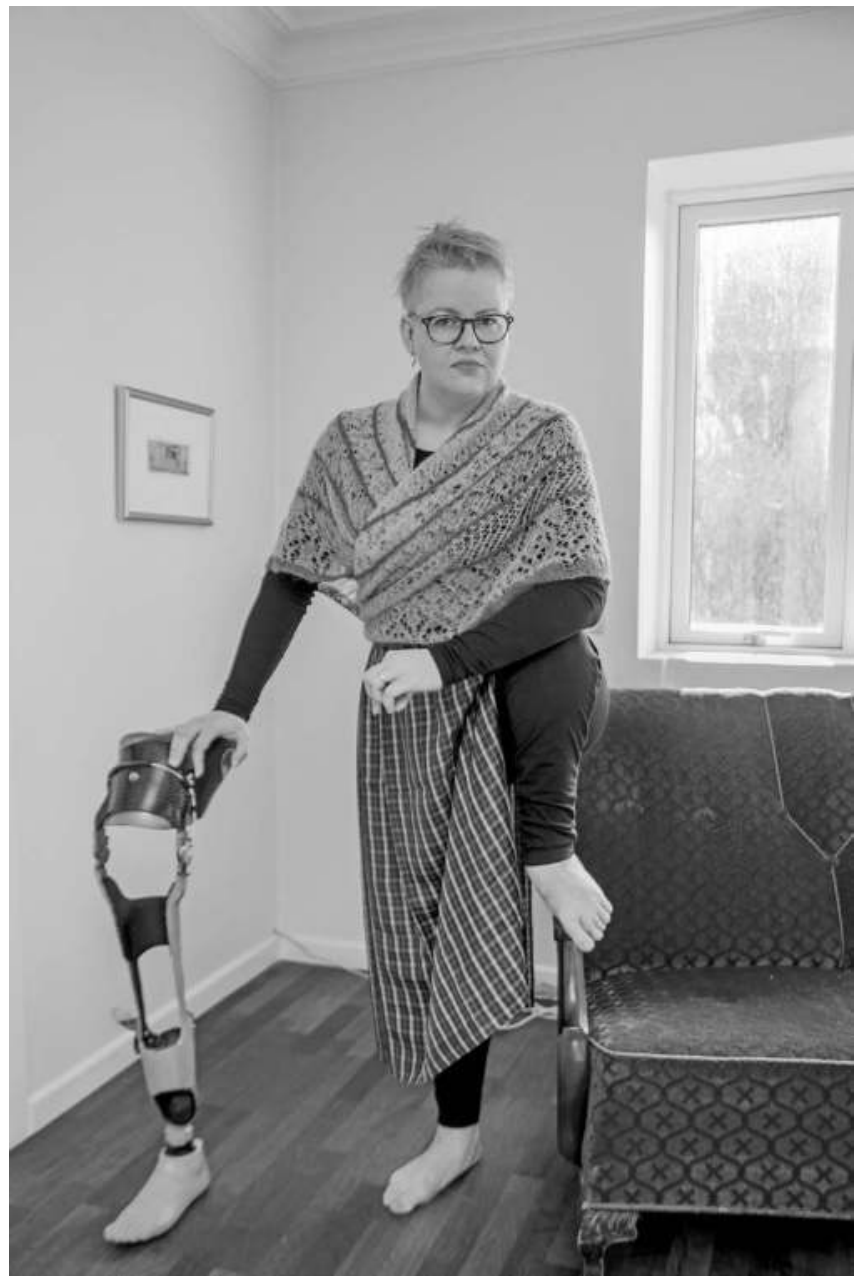

Figure 5.3 Eva Pórdís Ebenezersdóttir, stands next to a sofa chair. She is barefoot and her right foot is grounded on the floor while her left foot is propped on the carved wooden armrest of the sofa, bending her left arm in front of her resting the elbow on the knee. On her right she uses her hand to hold herprosthetic, designed for the left leg, standing next to her. The prosthetic is in yellow, gold and black colours, as well as steel and skin tones. She is wearing an old-fashioned apron in yellow and brown tones and has a knitted shawl around her shoulders in similar colours; both items are of high value to her and reflect Sigríður's Sunday best. In Sigríður's photo the chair is a scale used to showcase Sigríour's difference and impairment, her short stature. The viewer, however, does not know the actual size of the chair and the proof lies consequently in the eye and understanding of the onlooker. We can only wonder if Sigríður wanted to or agreed to showing her impairment with the aid of the chair. Here Eva Pórdís is looking directly at the audience, with a defiant smirk in her eyes, willingly showing her impairment and compelling the viewer to face her difference no matter how uncomfortable that might make them feel. 


\section{2 \\ E. P. Ebenezersdóttir and S. Ólafsdóttir}

about Sigríður: In 1825 (10 years old): "Unspeaking, deaf and unhappy." In 1838 (13 years old): "Does not speak and learns not what she ought." In 1832 (17 years old): "Cannot learn a thing." In 1833 (18 years old): "Does not speak." In 1834 (19 years old) "Reads haltingly - does not speak and learns not what she ought." In 1835 (20 years old): "Unintellectual." In 1836 (21 years old): "Close to an imbecile - cannot learn." The following year the priest changed his tone in his claims about Sigríður, writing in bold letters that "she could not learn anything good," and in the subsequent years he wrote "feeble-minded" in the column where the parishioners' behaviour was recorded (Myrká in Hörgárdalur parish, n.d. BC/4-1-1).

Sigríður Benediktsdóttir in Sörlatunga. A total runt, fragile and has been a dependent all her life. An imbecile, and before, when she was with her parents, she had a lacking process in learning to speak properly and knowledge of Christianity, but now, in the close to a year since she was taken from her father's home and has had a thorough guidance and she know the subjects, has knowledge of Christianity, what will happen hopefully, is fortune will choose a good place for her studies next winter. Her maintenance will be 148 fish] (Myrká in Hörgárdalur parish, n.d. BC/4-1-1).

Sigríður stayed for the next contracted year at Sörlatunga, with the farmer couple Guðjón Grímsson and his wife Ólöf Jónsdóttir for the last attempt to educate her for a confirmation. The parish priest described Ólöf in the parish records, early in 1846, in the following way: "Without a doubt the best person in M. [Myrká] Parish." In the same visitation Sigríður is described as "illiterate" though she knows both the "the subjects and the creed" by heart, and instead of her behaviour being described as "feebleminded" it changed into "adequate" (Myrká in Hörgárdalur parish, n.d. BC/4-1-1). At the age of 31, Sigríður was confirmed with a special license from the Bishop of Iceland. At that point she knew "small lessons of Luther and the confession, as well as verses and prays. [She] is illiterate, has difficulties speaking, and is terribly slow witted" (Myrká in Hörgárdalur parish, n.d. BA/6-1-1).

Later in the spring Sigríður was moved to a parsonage in Bægisá after working for bread and board at Féeggsstaðir. On that occasion, the following claim about Sigríður was noted in the county records: "The greatest runt who cannot find a workplace, cannot work long-term for her board, as well being in ill health. Her maintenance is now 120 fish." In the following years Sigríður was moved around the county, from one farm to another, and the claims about her focused mainly on her "bad behaviour" and "laziness." (Skriðuhreppur, n.d., H-7/3). Sigríður gave birth to a son on September 22, 1855. The boy was baptised the same day at Hólar in the parish of Bakkasókn where she had been placed that year. He was named Kristján Magnús and Sigríður declared that Friðrik Elíasson, a 
farmworker from Fnjóskadalur, was the father (Bagisá in Hörgárdalur parish, n.d. BA/6-1-1). Mother and son stayed together at Hólar for just eight months. In the spring of 1856, they were separated: The boy was placed at the farm Syðri- Bægisá in the parish of Bægisársókn and Sigríður was placed at the farm Saurbær in the parish of Myrkársókn. The county records described Sigríður at that time as "very unintelligent, of small stature, unskillful at work and lazy. Therefore, works very little and her maintenance this year is 62 fish." The county had to pay 323 fish for the maintenance of Kristján Magnús as he was fatherless and less than a year old according to the county record (Skriðuhreppur, n.d., H-7/3). The boy died from diphtheria at aged four, on the 20th of December 1859 on the farm Syðri-Bægisá (Bagisá in Hörgárdalur parish, n.d. BA/8-1-1). During those four years Kristján Magnús lived, he was a written about in the county record, where it was recounted that Friðrik, whom Sigríður had named as the father, denied the paternity. The boy was, therefore, always referred by his mother's name: Sigríðarson. There were complaints that no formal investigation had been undertaken regarding the paternity of the boy (Skriðuhreppur, n.d., H-7/3). Kristján Magnús died fatherless, and there is no evidence, either in the county record or in the judicial record of Eyjafjörour district that any efforts were made to find out who the father was.

Sigríður had been placed at the farm Neðstaland the year the boy died, where she was described as a "little worker, knows little" (Skriðuhreppur, n.d., H-7/3). She got to stay there for two years, until she was placed at Auðnubrekka in the parish of Möðruvallaklausturssókn where she stayed for almost a decade. Her health was not so good but improved quite a bit a few years later. Her maintenance was half that of a dependant's maintenance, or 120 fish. The following decade she was placed with her sister, Rósa, and her brother-in-law Guðmundur Guðmundsson. She moved with them from the farm Ásgerðarstaðasel to the farm Flaga where she was recorded with the claim "idiot." She was described as "crippled" the same year in the county record (Skriðuhreppur, n.d., H-7/3). It seems that Sigríður moved around quite a bit after that and in 1881 it was noted that her maintenance to her superiors, the farmers at Nýibær, was only minimum amount because she had "wandered a lot" (Skriðuhreppur, n.d., H-7/26).

Sigríður again stayed for a few years with her sister and brother-in-law in Nýibær in Myrkársókn. The claims about her during that time were "simple minded, half minded, knows little, and an orphan." In 1888 or when Sigríður was 73 years old she was described as "frail" (Skriðuhreppur, n.d., H-7/26). She was again described as "idiot" in the county records of 1890 (Census, n.d., AA/4-1-1). In 1891 she was named as "short Sigríður" and was placed again at Auðbrekka. The county officials allowed her to stay there for the next eight years even though she was registered at Skriða in the county record as she was then a "decrepit old person" (Möðruvallaklaustur in Hörgárdalur parish, n.d., BC/8-1-1, Skriðuhreppur, n.d., H-7/26). Sigríður 
Benediktsdóttir died on the 15th of April 1900, "a dependant on the county in Hólakot” in the parish of Möðruvallaklausturssókn.

\section{Stutta-Sigga in legends}

In 1940 an "Episode of Stutta-Sigga" was published in the magazine Gríma, tímarit fyrir islenzk pjóðleg frcoði, a journal that was a platform for folklore, legends, and popular histories. This publication became the foundation for most of the later recreated and reprinted legends about Stutta-Sigga. The "episode" is a cluster of legends Sigríður Benediktsdóttir who was, according to the legends, widely known as Stutta-Sigga. The legends span her life from a very young age to death, from stories of violence and hardship in her childhood that marked her body all her life. Her short stature, which is the basis for her nickname stutta or 'short', is grounded in her parents not being tall people and in addition malnutrition and hardship influenced her growth. The legends also tell of her education and confirmation, her pregnancies and childbirth. The last part of the legend cluster tells of her advanced age and interactions with people in her community, especially, men of power.

The legends about Sigga reflect the time of their telling or publication much more than the time of Sigríður's life, so the contextual information of who tells and who publishes the legends is consequently important. The "episode" is put together by Jónas Rafnar, one of two editors of Grima, and the material is credited to at least five editors, i.e., the landowners Guðmundur Guðmundsson, Höskuldur Magnússon, and Sturla Pórðarson, and the published authors Friðgeir Berg and Margeir Jónsson. These men belonged to the upper echelons of society and held both cultural and financial capital. As most of the editors were only born after Sigríður Benediksdóttir's death, they are, the second generation of storytellers when it comes to stories of Stutta-Sigga. It is likely that they heard the stories from fathers or grandfathers, and then narrated them to Rafnar who published the stories as the "Episode of Stutta-Sigga" (Rafnar and Jónsson 1940, p. 3-16). From this initial publication of the legends of Stutta-Sigga sprung many reprints in different media. First was Guðmundur Frímann, editor of the magazine Hjartaásinn (Ace of Hearts), who in 1948 selected three childhood stories from the original issue and reprinted them in his magazine along with the only photograph known to exist of Sigríður Benediksdóttir (Frímann, 1948, p. 27-29). The in the books Gríma hin nýja (The New Gríma) in 1964 (Jónsson, 1964, p. 236-238) and in a collection of local legends, Eyfirskar sagnir (Legends from Eyjafjörður), in 1977, where the picture of Sigríður is included (Rafnar 1977, p. 215-227). In the years 1954-1966 Stutta-Sigga and her family are mentioned on four occasions in a column called "stories of abandoned farms" in the newspaper Frjáls pjó $\varnothing$ (Porsteinsson 1954, p. 28, Ásgeirsson 1961a, p. 5, 961b, p. 3, 1964, p. 2, 1966, p. 3). Here, Sigríður Benediktsdóttir or Stutta-Sigga is only mentioned as 
one of 18 siblings from Flögusel and it is clear that the publishers expect their readers to know Sigríður's/Sigga's fate, life, and legends from the original episode in Gríma.

In the Christmas issue of the weekly paper Dagur in 1966, a selection of legends about Stutta-Sigga, spanning her life and accompanied with her picture, were printed. Most of the legends are again taken from Gríma. In addition, a man called Hallur Benediktson shared his memories of his great aunt Sigríður Benediksdóttir. The memory involves Sigga minding him as a child and that he was wary of her and scared she would pinch him, which she, however, never did (Stutta Sigga, 1966, p. 32). In 1987 Sigga is mentioned in an audio recording made by folklorist Hallfreður Örn Eiríksson who collected folklore material at the time. Eiríksson asks his interviewee if he has heard stories of StuttaSigga and the man responds that there had been stories of her haunting the countryside where she had lived, but then trivialises his recollection by saying that he does not remember clearly (Jónsson 1978). As the audio collection of Árnastofnun was not public at the time of the collection in 1987, Sigga does not make an appearance in published records for some time. It is only in 1992 that Dagur reprints the legends of Stutta-Sigga. The text is in most parts the same as before, but the context is a bit different. The title is now "Bæklaður sveitarómagi eftir mispyrmingar í æsku" ("A crippled pauper after violence in her youth.") The legends are also separated with uncouth subheadings, and it is accompanied by a vulgar pen drawing that shows a woman that has bent over, whipped her skirts above her hips showing her bare bottom as she peeks back towards the viewer with an obscene grin. The picture is a reference to one of the stories told of Stutta-Sigga in the paper (Sæmundsson 1992, p.11), the same story is discussed below.

Sigríður's photograph (see Fig. 5.2) is used in exhibitions throughout the 1990s where the artist defines her as a vagabond on the margins of society. This status of Stutta-Sigga as a part of a designated group of wanderers in Iceland's past is then strengthened by folklorist Jón Jónsson work about vagabonds in Icelandic legends and folklore in 2006. In the years following Jónsson has used his findings both for entertainment, through storytelling sessions as well as for further research and publication of the book $\dot{A}$ mörkum mennskunnar. Viðhorf til förufólks i sögnum og samfélagi (On the edge of humanity. Attitudes towards vagabonds in legends and society) (Jónsson 2006, p. 146-150, 2015, 2018, p. 25-32). Jónsson mostly builds on the texts about Sigga from Gríma hin nýja, and she is also one of two people he dedicates his book to.

In addition to the previously mentioned examples, there are a few smaller mentions of Stutta-Sigga but they do not tell the stories or give much context or information beyond her name. The most recent example in the long list of tales that form Sigga's story is this research, both presentations and this chapter, which accumulates the stories and not the least, tells them again. 


\section{The narrative afterlife of Sigríður}

By comparing and analysing the historical evidence and the legends reveals both congruities and incongruities in Sigríður's story. On this basis it is possible to see how a disability narrative comes to life. Information from the official records can be either similar as the folklore, or utterly contradictory. The reason for incongruities is that the records were collected and written by officials with authority over the individual, whereas the folklore is written down and published much later, as an interesting story, with no consequences regarding the real person in question. What is congruent between live, and legends is just as important as the similarities which give the legends the air of being true and important. The strongest similarities between the official records and the legends concern events of her childhood and death. When it comes to her adult life, however, the legends take flight and tell of events that the public records are silent about. In some cases that is because the stories are not material for public records, Jónsson points out that even if there is a historical connection between the legends and the life of Sigríður Benediksdóttir, the later narratives are first and foremost folklore, reflecting the ideas and attitudes of the storytellers of the 20th century (Jónsson 2018, p. 31). Despite this statement he uses the 20 th century legends to tell a believable story about the 19th century and does not reflect on the contextual meaning of the legend for the 20th century narrators or what ideas they are portraying by recreating the stories of Stutta-Sigga.

One of the most interesting cases of such incongruity between the official records and the folklore has to do with Sigríður having children. According to the legends she had two children, one when she was roughly 30 years old by a man in another parish. It is said that neighbouring (male) farmers ${ }^{4}$ assisted during birth as the midwife was not available. This was supposedly a difficult birth, and the child was stillborn or died shortly after the birth. A few years later Sigga had another child and when asked about the boy's father she pointed to a man who denied any such relations. By the power of the district sheriff, Sigga and the supposed father were called before a magistrate in Akureyri where the court ruled the man to be the child's father. The legend claims that Sigga prided herself on her child, saying that, even though she had not achieved much in her life, at least she had been a mother. The boy was, however, raised by others and died at the age of five (Anon 1940, p. 12-13). As mentioned above, Sigríður did have a son, Kristján Magnús, but he was her only child. By that time, the other child was allegedly already born, but there is no record of the child, stillborn or alive. Another incongruity is the supposed court case and the official recognition of Kristján Magnús' father. There would have been official records of that, but there are none. In addition, the record clearly lists Kristján Magnús as fatherless. What the two legendary accounts have in common, and is not found in the records, is the involvement of men in the affairs of 
Sigríður's pregnancies and birth's Men deliver the stillborn child and men of power and status in society concern themselves on Sigríður's behalf about the father of her child without consulting her. In addition, the magistrate, yet another powerful man, rules in Sigríður's favour when it comes to determining said paternity. In the years 1940-1970, when the legends are first published, this reflects both the power structure between the genders and the prescriptivism that governed the lives of disabled people (see Chapter 4 in this volume).

The fact that the magistrates and merchants are, in the legends of Stutta-Sigga supportive, is in contradiction to the legend tradition of the 19th century where the higher classes are more likely to be depicted in a negative light, as the oppressors and bullies. The storytellers of StuttaSigga are telling positive stories of their peers and using the poor and strange woman to emphasise their gracious gestures. Sigga is a tool to paint the men in the story in a positive light. This reveals how strongly 20th century ideas about for example body, gender andsocial class, colour the legends supposedly happening about a century before. The two-pronged method applied here has made it possible to claim that the legends paint a different picture as they reflect the time when the legends were collected and published rather than the real life of Sigríður.

The positive light of the gentry is one reason for the re-telling of the legends of Stutta-Sigga but there are other influential factors. In some of the legends of Sigga there are narrative elements that are reminiscent of older well-known supernatural legends. A good example of this is the following story:

When [Sigga] was living in Auðbrekka, her job was to herd cows to pasture, for a shortcut she stared herding them over a field that belonged to the next farm Hátún. The farmer there, named Gísli, disliked this shortcut and mentioned it to her often asking her to stop, but she did not heed him and replied to him with profanities. Once, as before Gísli spoke to her about this matter, but that time she turned his back to him, whipped her skirts up from her behind, peered between her thighs and called: "look in the mirror dear Gísli!". It goes without saying that Sigga was not wearing any panties (Anon, 1940, p. 13-14). ${ }^{5}$

At first glance this short narrative may seem to be a crude, and for many a humorous, story of how strange and off-putting Stutta-Sigga was seen. The most important part of the story is not the little old woman with the low social status but the agency and gumption to moon at her superior, male neighbour to get him to leave her alone. This same theme can be found in tales of how to repel a supernatural being, the repelling trick is to do exactly what Sigga does, moon the ghost (Gunnell 2014, p. 43-44). ${ }^{6}$ The powerplay in such ghost stories is also often like where a human is trying to get a more powerful being to leave them alone. The resemblance is uncanny, and there 
are other legends in the cluster about Stutta-Sigga with similar connections to known folktales and legends.

Sigga even fits into the role of the underprivileged in folk and fairy tales when she is described to have been clothed in rags as a child, living in dirty corners. In one story it is even claimed that she was sleeping in the cinders of the hearth. Even if Sigga is no Cinderella, the legends about her do have legend and fairy-tale elements known to the audience that aid the narrative power of the stories. Usually, stories change with time adjusting to the understanding and mindset of the audience and storytellers (Porsteinsdóttir 2011, p. 80-82). As mentioned before, the republished texts about Sigga are almost identical from one to the other. As the texts adhere to well-known themes and phrases from legends and fairy tales, they catch the audience's interest and facilitate connecting to the stories.

By connecting the stories of a real person to known folktales, the story also becomes a vehicle for the narrative's agency, meaning and function, bringing forth another reason for recreating the stories. The meaning and understanding changes dramatically due to the context given each time. Such changes of meaning caused by changes of context can give us insight into how and why certain ideas about people, and bodies, that are considered different become rooted and traditionalised in social memory by the means of folklore, forming, and reforming our ideas about others. Moving through time and generations, originating in gossip about Sigríour, the legends about Stutta-Sigga take us from narratives of a real-life person, with a different body and behaviour, to folklore of accentuated difference and marginalization set in familiar story.

\section{Sigríour in photos}

The third strand in the weaving of Sigríour's story is how the photograph of her has been used. In the legends, the photograph (see Fig. 5.1) is mentioned; and it is used both in publications of the legends, as well as on two more occasions, in Dagur in 1966 and in Jónsson's book Á mörkum mennskunnar in 2018.

While Sigga was living in Skriða she once took it upon herself to go over to Bægisá to find out from the church records when she had been born. A little while later some neighbours were invited to her birthday celebration. It was a lively gathering, and Sigga was in the seventh heaven, and very happy for the occasion, as she got a few small birthdays presents. She claimed that this was her first birthday. Sigga's photograph was taken around the same time; it was a good photograph and can be found in many places (Anon 1940, p. 16).

This legend is interesting, as it upholds the idea of Sigga as an old woman being very active and with a strong agency to go after what she wants. We are also given the sense that she is respected and liked, as the family she lives with throws her a party, which her neighbours attend complete with 
presents. Both attendance and gifts are an act of kindness and regard for the old and often difficult woman. In the end, the strength, agency, respect, and kindness are, however, shadowed by the notion that Sigga did not know her birthday until she was in old age, and by her claim that this was her first ever celebration of the day. Even here in this happy and joyful legend we are, once again, reminded of Sigga's difficult lifespan on the margins of society.

Then, in 1991, artist Birgir Andrésson uses Sigríður's photo in an exhibition showing 60 black-and-white photographs, along with names of people that all are long dead. Andrésson titles his assortment of photos Annars vegar fólk (Other kinds of people) (Andrésson 1991). Nine years later Andrésson sets the exhibition up again with the same title privately at Reykjavíkur Akademían, and publicly at the National Gallery of Iceland (Andrésson 2000). In 2010 the Akureyri museum used the photo of Sigríður as part of the exhibition The treasures of Eyjafjörour where the photograph is credited to Jón Júlíus Árnason and claimed to have been taken in Akureyri (Hallgrímsson 2010, p. 25). As mentioned above, the folklorist Jón Jónsson has also used the photo both in his publication in 2018, as well as in teaching and storytelling in the last few years.

Disability scholars have criticised how images and impairments have been paired together to emphasise the strangeness of the body, with no regard or respect to the person portrayed (Garland-Thomson 2009, p. 79-94, Snyder and Mitchell 2010, p. 156-181). The same criticism holds also true for both photographs of Sigríður: In both cases the pictures have been transmitted without context or description. In Fig. 6.1, the presumed oddity of her height is emphasised by the chair that represents a scale of reference; and Andrésson's (1991) usage and the discourse in his exhibition Annars vegar fólk stigmatises her as 'odd' and not as an individual in her own right.

With the photo exhibition in 1991, then repeated in 2000 , a radical addition is made to the narrative of Sigga's life. Andrésson published a book to accompany the exhibition titled Nálagd Annars vegar fólk (Proximity People on the Other Road), where he claims not to be a historian but a mere artist doing his best to shed light on the diversity that forms culture. At the same time, he clearly situates these individuals as outsiders, wanderers, and those who do not fit into the society of the past, as well as romanticising their situation by implying that their marginalised and ostracised position was by their own choice (Porláksson 1991, p. 28, Proppé 2000, p. 32). Wandering, in Iceland, at the lifetime of Sigríður and the others portrayed in Andrésson's exhibition, was in most cases involuntary, a lifestyle forced upon people by society and the authorities (Jónsson 2018, p. 14-21), as can be seen in the life-thread of Sigríður. Andrésson recreated the narrative of Sigríður, and others, by forming a strong romantic context of the free and strange individuals that simply did not fit in with others. For Sigríður this addition to the narrative erases the context of the tension 
between social responsibility and the wandering, leaving the story with a character which has little or no connection to her society. She has become Stutta-Sigga, a free-spirited character that defied society's norms and chose to wander. Gone is the real Sigríður who, throughout her life, was forced by the local authorities to wander between homes, as well as being bullied and gossiped about.

The photographic representation we offer here proposes a counternarrative to the all too familiar "freakish" photos of disabled people, which have little or no connection with the persons themselves, as the focus is purely and only on their embodied difference and disabilities. We propose that such old photos can be used but it is essential that they are approached with respect. We want to create a staring space and context (GarlandThomson 2009, p. 79-94) that is safe and respectful to Sigríður, as well as the watchers and readers of the picture. To make that safe and respectful space we do draw up a rich context of the life and afterlife of the person pictured, context is based on well researched sources analysed from the viewpoint of the subject, Sigríour, and disability studies.

Both the analysis of the old photograph, and the design for the new photo are based on Roland Barthes (1915-1980) book Camera Lucida. Barthes describes the difference between what he referred to as studium, a cultural, linguistic, and political interpretation of a photograph, and punctum, an emotional, wounding and personally touching reaction which establishes a direct relationship with the object or person within the photograph (Barthes 1981, p. 26-27).

What we attempt with the new photo (see Fig. 5.3) is to defy the repeated story of a beaten and rude little woman by recreating the narrative with respect, drawing on emotions of pride, defiance, and life-saving stubbornness; aspects that we experienced during our preparation for this chapter. We have discovered a tenacious Sigríður, and that is the story we want to tell and re-tell with all the photos and the context of the story of her life and legends created and re-created.

\section{Conclusion}

Our detailed analysis reveals how the physical and mental impairments of Sigríður marked her as different from the alleged norm of her society. That difference then inspired talk that had a disabling effect on Sigríður's life, disabling her with and through stories. While her different body and behaviour ceased to exist, the gossip did not die with her. The stories continued and have been re-created throughout the decades. Sigríður's life has gradually been turned into a fixed, legendary, and somewhat stereotypical account of her character as different. She has been transformed from a real person with differences to a legendary character of disability.

Dropping the prefix Stutta (e. Short) does not take away from Sigríður's embodiment of difference, but it reminds us to think of her as a person with 
her own experiences and life, before focusing on her difference and disabilities. Sigga was born at Flögusel in the year 1815 and experienced abuse and hardship during her childhood that marked her for life. As a teenager and young woman, she had her own way of understanding her surroundings and did not fall easily into the mould that society had carved for her peers. As she did not learn and speak as others, she was denied the right of Christian confirmation and the traditional passage to adulthood at the age of 14 . It was years later that a priest from a neighbouring parish realised that, even if she did not do things like others, she still knew and understood the values of Christianity that society expected of people. With his help she was confirmed and became an adult at the age 31. Despite this transition people did not fully know how to be around Sigga, and all her life she was kept on the margins of society, expected to wander between households and seldom having a steady home. Everywhere she came she was put to work for her board before being sent on to the next farm. And people talked.

They talked about her difficult childhood, they talked about her body and how it was different, they talked about the way she spoke and how she understood the world. They talked about her wandering, and her relationships with men. They talked about her pregnancy, the father of her child, and the child itself. They talked about her strangeness, struggles and temper. At the age of 85, Sigga passed away, after a long and hard life on the outer margins of society. The talk did not die with her, but kept going and growing, taking on elements of different understanding as the times changed. Forty years after Sigga died, the talk was written down and printed, and the stories thereby fixed on the pages of the legend journal Gríma. The talk about Sigga had been elaborated and accentuated to make her legendary, exciting, and horrifying, a story worth telling. The talk was over, text had taken over and no matter how much the times changed, the story did not. Time did affect the text, by turning and twisting its meaning, turning Sigga's life into a vision of the cruelty of the past and a grotesque joke, where she was increasingly diminished, into a stereotypical character of a weird and insufferable little old lady, to be laughed at.

The text, the story, the former talk is still here but times have changed yet again. Making fun of different and disabled people is not tolerated anymore, and the past was more complex than formerly believed. After this winding journey we look at Sigga's life, legends, and photo with a new perspective of curiosity, laced with honour and respect. What we find, then, is a woman who was stubborn to the point of self-preservation, living through hardship, exclusion, and loss her whole life, and even beyond the grave as her position of powerlessness in life was continued and accentuated in the legends later told. At this point in time, we want to give Sigga back power in her own story. We look at her life, legends and photograph with an open mind and witness in them a survivor of disabling attitudes and circumstances. We tell her story anew in the academic setting of this chapter, as well as the disability art of new photograph, inspired by Sigga herself, giving her the respect, 


\section{E. P. Ebenezersdóttir and S. Ólafsdóttir}

she earned but was never given, and the power she never had a chance to wield. We can only hope she approves.

\section{Notes}

1. Publishing of folktales has been a highly editorial process and has tended to fix the stories, so they move away from oral tradition to more of a literature tradition. See for example Gunnell, T., 2010. Daisies rise to become oaks: The politics of early folktale collection in northern Europe. Folklore, 121 (1), 12-37. Doi: 10.1080/00155870903492063

2. It is worth mentioning that the gossip about Sigríður must have been limited to the local area of where she lived. In line with this, the legends were also mostly locally printed and published until the last decade of the $20^{\text {th }}$ century. Newspapers and periodicals were local and even the legends published in books that might have gotten a wider audience are always linked strongly to the area in question. It is not until recently that Sigríður's horizon has broadened, and her stories have become more widely known.

3. Translations of the phrases in this section are by Sólveig Ólafsdóttir for this chapter.

4. Apparently, it took no less than three grown men to deliver the child and the discourse of the story paints them in most heroic colors while we know nothing of Sigríðurs response to the loss of the child or the aftermath of the difficult birth.

5. Translation of the legend by Eva Pórdís Ebenezersdóttir for this chapter.

6. Bengt af Klintberg classifies this tale type as C "Showing one's backside to a pursuer" (af Klintberg, B., 2010. The Types of the Swedish Folk Legend. Academia Scientiarum Fennica. p. 63). An example of this legend in Icelandic lore is the story "Horfðu í glóðaraugað mitt, Gunna," in Jón Porkelsson legend collection from 1956, p. 31.

\section{References}

\section{Archives}

Jónsson, B. (1978). Stutta-Sigga gekk aftur, en heimildarmaður man lítið um pað nána. [audio recording] SÁM 92/2989 EF. Audio recordings of Hallfreður Örn Eiríksson. The Árni Magnússon Institute for Icelandic Studies. Reykjavík.

Bagisá in Hörgárdalur parish. n.d. [Manuskript] BA/6-1-1. Church records Bakka 1844-1880. The national archives of Iceland. Reykjavík.

Baggisá in Hörgárdalur parish. n.d. [Manuskript] BA/8-1-1. Church records1844-1880. The national archives of Iceland. Reykjavík.

Census. n.d. [Manuskript] AA/4-1-1. The census 1850, 1855, 1860, 1870, 1880, 1890 in Húnavatnssýsla, Skagafjarðarsýsla og Eyjafjarðarsýsla. Statistisk bureau 1904. The national archives of Iceland. Reykjavík.

Kona, peysuföt. n.d. [Photograph]. STÆ2-282. Mynd. The District Archives in Akureyri, Akureyri.

Möðruvallaklkaustur in Hörgárdalur parish. n.d. [Manuskript] BC/8-1-1. Church records 1881-1899. The national archives of Iceland. Reykjavík.

Myrká in Hörgárdalur parish. n.d. [Manuskript] BA/6-1-1. Church records 1839-1858. The national archives of Iceland. Reykjavík. 
Myrká in Hörgárdalur parish. n.d. [Manuskript] BC/4-1-1. Church records 1820-1830 and 1832-1847. The national archives of Iceland. Reykjavík.

Myrká in Hörgárdalur parish. n.d. [Manuskript] BA/3-1-1. Church records 1820-1830 and 1832-1847. The national archives of Iceland. Reykjavík.

Skriðuhreppur. n.d. [Manuskript] H-7/26. County records 1881-1902. The District Archives in Akureyri, Akureyri.

Skriðuhreppur. n.d. [Manuskript] H-7/3. County records 1835-1849. The District Archives in Akureyri, Akureyri.

The national archives of Iceland. n.d. The national archives of Iceland. Census database. [online] Available at: <http://manntal.is/?lang=en $>$ [Accessed 9 March 2021]

Andrésson, B., 1991. Annarskonar fólk. Reykjavík: i8 gallerí.

Andrésson, B., 2000. Annars vegar fólk. Reykjavík: ReykjavíkurAkademían.

Atkinson, D., and Walmsley, J., 2010. History from the inside: towards an inclusive history of intellectual disability. Scandinavian Journal of Disability Research, 12 (4), 273-286. Doi: 10.1080/15017410903581205

Ásgeirsson, J., 1961a. Pættir af eyðibýlum: VI. hluti. Frjáls pjóð, (10/8), p. 5.

Ásgeirsson, J., 1961b. Pættir af eyðibýlum: VII. hluti. Frjáls pjóð, 10 (9), p. 2-3.

Ásgeirsson, J., 1964. Sagnir frá eyðibýlum. Frjáls pjóð, 13 (18), p. $2-7$.

Ásgeirsson, J., 1966. Sagnir frá eyðibýlum. Frjáls pjóð, 15 (25), p. 3-4.

Barthes, R., 1981. Camera lucida: Reflections on photography. London: Fontana.

Creswell, J. W., 2009. Research Design: Qualitative, Quantitative, and Mixed Methods Approaches. 3rd ed. Thousand Oaks, CA: SAGE Publications.

Dégh, L., and Vázsonyi, A., 1974. The Memorate and the Proto-Memorate. The Journal of American Folklore, 87 (345), 225-239. Doi: 10.2307/538735

Dégh, L., 2001. Legend and belief: Dialectics of a folklore genre. Bloomington, IN: Indiana University Press.

Fogel, C., Quinlan, A., Quinlan, L., and She, Q., 2010. Ethical Issues in SocioHistorical Archival Research: A Short Skit. Research Ethics, 6 (3), 91-94. Doi: 10.1177/174701611000600305

Frímann, G., 1948. Kynlegir kvistir. Stutta Sigga. Hjartaásinn, 2 (1), 27-29.

Garland-Thomson, R., 2009. Staring: How We Look. Oxford: Oxford University Press.

Gunnell, T., 2014. Magical Mooning' and the 'Goatskin Twirl': 'Other' Kinds of Female Magical Practices in Early Iceland. In: T. Thangherlini, ed. Nordic Mythologies. Interpretations, Intersections, and Institutions. Los Angeles: North Pinehurst Press, 133-153.

Hallgrímsson, S., 2010. Eyfirskur fjársjóður. SunnudagsMogginn, 13 June, p. 24-25. Honko, L., 1964. Memorates and the study of folk belief. Journal of the Folklore Institute, 1 (1), 5-19. Doi: 10.2307/3814027

Hufford., 2003. Context. In: B. Y. B. Feintuch, ed. Eight Words for the Study of Expressive Culture. Urbana, IL: University of Illinois Press, 146-175.

Jónsson, J., 2018. Á mörkum mennskunnar: Viðhorf til förufólks í sögnum og samfélagi. (Sýnisbók íslenskrar alpýðumenningar). Reykjavík: University of Iceland Press.

Jónsson, J., 2006. Förumenn i íslenska bandasamfélaginu. Thesis (MA) University of Iceland.

Jónsson, J., 2015. Hugleiðing um hörmungarlif: Stutta-Sigga, Jóhann beri og fleira fólk. 22 February 2015 Hólmavík, IS: Saufjársetur á ströndum. 


\section{E. P. Ebenezersdóttir and S. Ólafsdóttir}

Jónsson, P.M., 1964. Gríma hin nýja. 2nd ed. Reykjavík: Bókaútgáfan Pjóðsaga.

Latvala, P., and Laurén, K., 2013. The sensitive interpretation of emotions: Methodological perspectives on studying meanings in oral history texts. In: J.A. Frog and P. Latvala, ed. Approaching Methodology. Helsinki: Finnish Academy of Science and Letters, 249-266.

McKee, H. A., and Porter, J. E., 2012. The Ethics of Archival Research. College Composition and Communication, 64 (1), 59-81.

Michalko, R., 2002. The Difference that Disability Makes. Philadelphia: Temple University Press.

Michalko, R., 2017. Things are Different Here: And Other Stories. Toronto: Insomniac Press.

Michalko, R., and Titchkosky, T., 2020. Blindness: A Cultural History of Blindness. In: D.T. Mitchell and S. L. Snyder, ed. A Cultural History of Disability in the Modern age. London: Bloomsbury, 61-78. Doi: 10.5040/9781350029323.ch-005

Oring, E., 2008. Legendry and the rhetoric of truth. The Journal Of American Folklore, 121 (480), 127-166. Doi: 10.2307/20487594

Proppé, J., 2000. Landar Birgis. Morgunblaðið, 11 May, p. 32.

Rafnar, J., 1977. Eyfirskar sagnir. Reykjavík: Almenna bókafélagið.

Rafnar, J., and Jónsson, P.M., 1940. Páttur af Stuttu-Siggu. Gríma, tímarit um islensk pjóðleg frææði, (15), 3-16.

Sæmundsson, S., 1992. Bæklaður Sveitaómagi eftir mispyrmingar í æsku. Dagur, (97), 11.

Snyder, S. L., and Mitchell, D. T., 2010. Cultural Locations of Disability. Chicago: University of Chicago Press.

Stutta Sigga, 1966. Dagur, (49), 32.

Tangherlini, T. R., 1994. Interpreting legend: Danish storytellers and their repertoires. London: Garland Publishing.

Porláksson, E., 1991. Nálægð. Morgunblaðið, p. 28.

porsteinsdóttir, R., 2011. Sagan upp á hvern mann. Reykjvaík: Stofnun Árna Magnússonar í íslenskum fræðum.

Porsteinsson, J., 1954. Bæjarvísur um bændur í Myrkársókn. Dagur, 37, 28.

Titchkosky, T., 2002. Cultural Maps: Which Way to Disability?. In: M. Corker and T. Shakespeare, eds. Disability/Postmodernity: Embodying Disability Theory. New York: Continuum, 145-160.

Titchkosky, T., 2007. Reading and Writing Disability Differently: The Textured Life of Embodiment. Toronto: University of Toronto Press.

Titchkosky, T., 2009. Disability images and the art of theorizing normality. International Journal of Qualitative Studies in Education, 22 (1), 75-84. Doi: $10.1080 / 09518390802581893$

Titchkosky, T., and Michalko, R., 2014. Chapter 32: Narrative. In: C. Cameron, ed. Disability Studies: A Student's Guide. Los Angeles: SAGE Publications, 101-103.

Wilkinson, T. M., 2002. Last rights: the ethics of research on the dead. Journal of Applied Philosophy, 19 (1), 31-41. Doi: 10.1111/1468-5930.00202 


\section{Dis-/abling Absence \\ Absencepresence as matters that matter}

Arndís Bergsdóttir

\section{Preface}

At Hnjótur, a rural heritage museum in the Westfjords in Iceland, a prosthetic hand, and grips (which, according to the catalogue, are repurposed hand vises) are displayed in the museum's exhibition along with two chisels that fit the prosthetic hand. These prosthetics belonged to the blacksmith Ólafur Björnsson from Keflavik who was born in 1858 and lost his left hand after an accident in 1887 involving an undetonated munition from a French military vessel sailing off the west coast of Iceland. Along with these objects, the museum also preserves letters between the doctor who amputated Ólafur's hand and a man who assisted him in the surgery, but the letters are mainly detailed reminiscing's about the amputation as a medical procedure and inquiries about Ólafur's health. The discussions in the letters underline normalised notions about capabilities that diminish the unruliness of bodies: In one place it says that following the amputation Ólafur did both carpentry and ironwork and was dexterous and "a very good blacksmith," a point iterated in the museum's display text. It was also noted that he had continued to go out to sea by himself and, with a "rowing cord" he had fashioned for himself, he could row so well that "seen from afar one would think that there was a man with two hands." Using a special technique Ólafur was "just as quick to draw the fish in as men with whole hands."

Skógar museum, located in the south of Iceland, is perhaps one of the largest rural heritage museums outside the capital of Reykjavík. Located close to well-known tourist sites, the museum includes an open air exhibition with historical buildings and a museum of transport as well as a folk museum which houses exhibitions that narrate stories about natural histories, agriculture, fisheries, and domestic living. In short, the museum exhibits stories about living in the region with, as expected in museums of this kind, an emphasis on well-known characters in the community. After studying the exhibitions, looking for evidence of disabled people in the museum's area of operation, only a single image stood out. Behind a door on the museum's second floor an intricately embroidered floral image hangs inconspicuously among a selection of miscellaneous artefacts. A subtle sign 
says: "Handiwork of a blind woman." It states, only in Icelandic, the name of the woman, Margrét Andrésdóttir, and that she was the chairperson of the Icelandic Association of the Visually Impaired. Further investigation into her life revealed that she was, indeed, one of the association's founders and where she served as chairperson for over a decade. After discussing the issue of disabled people's stories in museum exhibitions with museum staff they became intrigued and helped hunt down more of Margrét's things in the museum's exhibitions and depositories. Two other objects were found in the exhibition and a few more in the depositories. The floral image behind the door was, however, the only instance where Margrét was mentioned, and attention was drawn to her disability. The museum's catalogue mentions her disability once: "Margrét Andrésdóttir was blind for many years but did numerous jobs like a seeing person."

For decades, The National Museum of Iceland has collected stories from their public for its collection of folk customs and ways of life. One such story mentions a woman named Guðrún, born in 1924, who lost one of her legs when she was 17 years old. The story is based on an interview but early in the story the interviewer pauses to note that Guðrún's medical history is rather unusual. The storyteller subsequently shares how Guðrún lost her leg after an accident on ice skates and that her left arm was half paralyzed, causes of which are not mentioned. This brief account ends with: "She did not give up but went straight to Reykjavík and got herself an artificial leg and kept going and went straight to work as others who are completely healthy."

\section{Introduction}

"Disability is everywhere, once you know how to look for it" (GarlandThomson 2014). These words were central to Rosemary Garland-Thomson's keynote at The Icelandic Disability Alliance's 2014 symposium where she, along with Icelandic scholars, discussed representations of disabled people in mainstream culture. There is not only merit in this statement in terms of the socially just act of paying attention to different ways of being in the world; It is also productive in the sense that it troubles entrenched ways of thinking about who gets to be included and how. In other words, it reminds us that even though certain matters are far from being foregrounded in a world that favours able-bodiedness as the normalised way of being and becoming in the world, they are no less there. At the time it seemed to me such an obvious observation. This concern would, however, come up a few years later. I was immersed in the project Disability before Disability focusing my efforts on "looking for" stories about disability and the lived lives and experiences of disabled people in museums. Research that examines the relationships between museums and the histories of disabled people have been few and far between. Whereas issues of race, gender, and mobilities have received, at least some, attention on 
the whole museums seldomly engage with ideas about equality and social justice. Their application seems only discernible in individual museums or isolated within certain progressive wings within the museum sector. This leaves striking absences when it comes to disabled people's lived lives and experiences (Sandell and Nightingale 2013) on a general scale. In 2004 the University of Leicester based project Buried in the Footnotes issued a report based on its investigations of the hidden histories of disabled people in museum and gallery collections. Based on this research that examines the representation of disabled people in culture (Dodd et al. 2004), as well as general reason, it should follow that if I looked for them, I would most certainly find them deep in the crevices of Icelandic museum collections.

I began with The National Museum of Iceland. The gateway to the collection, for the public, researchers, and curators, is almost invariably the museum's digital registration of artefacts, as roaming around the depositories and opening boxes of collected things is seen to defy security and the wellbeing of museum objects. As I mined the contents of vast depositories through the Icelandic registration database Sarpur, looking for traces of disabilities by applying every search word and combination of terms I could possibly imagine, only a handful of objects came up. These were either fleeting mentions of a missing extremity in memoirs or surgical tools and other objects pertaining to the museum's medical collection but not the lived lives and experiences of disabled people as part of communities and the nation. Disability is everywhere once you know how to look for it. Yet, in the catalogues of The National Museum of Iceland, something that is, and certainly was historically speaking, everywhere was not there. What seemed to be everywhere in the museum's catalogue and depositories was, in this sense, absence.

This was a moment of pause and reflection. There is no ambiguity, I feel, involved in "looking for" disability as a human action that is aimed at emancipating marginalised people, objects, issues, and stories as they are brought in from a shadowy periphery. There is however a twist, or rather a turn, that can be taken, where the act of searching is questioned as a viable option when standing before a plethora of absences. These absences were not invisibilities awarded to identities that seem to adhere so well to current constructions of "normal" and, as Sarah Ahmed (2007) describes in her work on racial identities and institutions, are so obvious that they become invisible (Garland-Thomson 2011). Throughout the research I could feel the violent presence of absence that comes from quiet disregard (Azoulay 2019, Kinder 2014). But I could also feel its resistance to indifference and an urgency for attention and trust. So, the question remained: Should I power through the technological and discursively grounded gatekeepers to find something? In other words, should I react to the absences? Or should I stop and notice, pay attention to the absences that were there and the concerns they entail? After all, if absences are there, don't they matter as integral 
components of disabled people's heritage and histories as they have come into being in museums? Is attention and trust not what absences of disabled people's lives and experiences deserve?

Of concern are the significant gaps in public historical narratives where some stories get to belong while others are forgotten. But absences are not necessarily well defined matters. They crouch in the in-betweens, in the unruly spaces that defy binary logic (Basu 2017) and invite relational becoming's, as the subtle entities brought about by stereotypical depictions. Such depictions are apparent in the glimpses of the renderings of Ólafur, Margrét, and Guðrún at the beginning of this chapter, and which I shall discuss in the next section. These glimpses align with earlier studies, particularly in the U.K. (Dodd et al. 2004) and indicate how the narrow expectations of an ableist world show up to supersede specific lived lives and experiences that should have equal standing among the stories that form museum narratives in general. I would like, in this context, to refer back to Rosemary Garland-Thomson's (2014) observation that disabilities are everywhere once we know how to look for them and note that perhaps disabilities cannot only be defined by their presences but their absences as well. When we look, should the presence of absences not also be noticed and respected? Are they not matters that matter among other matters? As I have argued elsewhere (2017) absences are enmeshed in the histories of subordinate social groups as they have been produced and reproduced by cultural institutions, such as museums. Here, the stories that belong to disabled people are no exception (Delin 2002) and they are, I claim, integral elements of museum materialities. Why, then, should they be left as inconsequential nothings rather than claiming ownership? And what would such ownership entail? First, however, absences need to be approached. Not as nothings or gaps to be filled with presences but as significant matters: As stories that involve a matrix of inclusions/exclusions, ir-/responsibilities, in-/actions, un-/ruliness, and dis-/abilities. As material entities that are inextricably entwined with presences in ways that challenge the hierarchal dichotomies we seek to overcome.

In this chapter I introduce such an approach to absence in the context of disabled people's histories and heritage. I begin with a brief description of the frameworks within disability studies that inform my discussion about the enmeshments of absence, disabled people's histories and heritage, and museums. It is followed by discussions about the concerns that arise from such entanglements and although these observations are constricted by the length of this chapter they are meant, at least in broad terms, to set the stage for matters of absence. Drawing from these and the concept of absencepresence (Bergsdóttir and Hafsteinsson 2018) I continue sketching a tool to critically examine the enmeshed matters of absence and presence, of inclusion and exclusion, and the ethics that are always already involved. Absencepresence refers to a hybrid matter that 
is always already entangled with museum matterings. It has the potential to create avenues for messy discussions about the entwinements of histories and heritage of dis-/abled people, the exclusionary practices of cultural institutions, and the responsibilities they find hard to claim. This speaks to the central theme of the project Disability before Disability, for orienting towards a past means awareness: It means showing appreciation for absences, and recognizing agencies thus consciously attending to how a future comes to matter.

\section{Crips and misfits}

Applying absencepresence to frame owned histories of dis-/abled people and the responsibilities involved claims coalition with crip theory (McRuer 2006, 2018) and Rosemary Garland-Thomson's notion of misfitting (2011). The crip framework troubles both the medical model of disability that reduces disabled bodies to pathological concerns that must be dealt with and the social model which seeks to disengage the relationship between bodies and disabilities repeated throughout the medical model and focus instead on disabilities as socially constructed phenomena that have nothing to do with bodies but everything to do with social values and norms demarcated by access (McRuer 2018). The social model has been of considerable value. Here, however, it is appropriate to involve crip theory in the conversation as the framework seems willing to critically dismantle the imagined boundaries that produce differences and examine the histories of dis-/abled bodied people as histories of institutions and their practices rather than fall into the traps of additive approaches (McRuer 2006, 2018, Ray and Sibara 2017, Schalk 2018).

Whereas cripping provides opportunities to critically examine the subtle absences of disabled people's narratives and the implications of institutional performances of heritage, misfitting does not turn away from disability as a social construct but turns to include the materialities of bodies (Garland-Thomson 2011, Alaimo and Hekman 2008). This underlines matters of absencepresence, when applied to absences of disabled people's stories, and the cultural institutions (museums and heritage) that shape them are always already reciprocal relationships that enact consequences. Also, misfitting fuels exclusionary practices as a response (or ir-/respons/ability) to museum practices that fit well with abled-bodies while misfitting with dis-/abled lives and experiences (Garland-Thomson 2011). Thus, maintaining a system of compulsory abled-bodiedness (McRuer 2006). As iterated throughout this chapter, recognising absencepresences as part of human entanglements in and of the world is a question of responsibilities and ethics: Issues that are imperative to name in relation to the exclusions ingrained in museum practices. These are matters that come into being through complex constellations of dynamic relationships. 


\section{Do histories of disabled people matter among museum matters?}

There is an overarching consensus that museums, particularly those of history and heritage, collect, catalogue and exhibit a past, in the present, for the future. At first glance this general phrasing of the quintessential purpose of museums seems to depict them as passive channels for versions of truths: Platforms from which history (in the singular) can be observed as it flows from a past and into a future in a movement that signals tenacious notions of linear progress (Bodo 2012). Yet, decade's worth of scholarships illustrate how museums are agentic institutions that actively and systematically generate specific worldings (Gaskell 2012, Hooper-Greenhill 2000, Olsen and Svestad 1994, Ott 2005, Preziosi 2012, Sandell and Dodd 2010). Although the generative aspects of museums and their processes cannot be exhausted here, I will briefly elicit examples highlighting how exclusionary practices work within the bounds of museum practices, and how they call for care.

Mining of the database that keeps registrations of objects in The National Museum of Iceland yielded relatively few results. The database includes a vast majority of the 120 thousand artefacts that occupy the museum's depositories, however this study focused on artefacts as these, in general, comprise the basis of The National Museum's permanent exhibition and narratives about communities and social life in the country. This meant that antiquities were excluded along with the photographic collection. The medical collection, that belonged to a specific museum of medicine but is now a collection within the realm of The National Museum, was included in the search. Another parameter was that the objects predated the first disability legislation in Iceland in 1936, although examples of misregistration made it hard to pinpoint some objects exactly within that timeframe (Guðmundsdóttir Eydal 2020). Of the material evidence registered in the database 64 objects were identified as relevant to disability most of which were in the medical collection. These included more than a dozen prosthetic eyes that all belonged to the same person, equipment for physiotherapy and surgical tools used for amputation, but also crutches, calliper splints, and two wheelchairs (Guðmundsdóttir Eydal 2020).

The objects pertaining to disabled people and encountered in the depositories of The National Museum of Iceland, largely belonged to the museum's medical collection. This is no surprise, as the medicalisation of disabled bodies (Garland-Thomson 1997, Shakespeare 2017) and technological innovations are inextricably linked. Indeed, the discriminatory factors that place the stories of disabled people at the periphery of museum narratives, and society as a whole, tend to present technologies, including prosthetics and wheelchairs, as solutions, or additions that will mend disabled bodies and lives (Ott 2018). as It is also relevant to note that an absence of objects, as the ones encountered in The National Museum of Iceland's 
depositories and which is also observed in the survey included in the project Buried in the Footnotes (Dodd et al. 2004), may indeed be material evidence that is central to disabled people's histories. As Katherine Ott (2018, p. 126) has noted some objects are of little or no use to some disabled people and poverty may also enhance a scarcity of objects. Yet, museums traditionally tend to make meanings through the contextualisation of objects and an absence thereof has an effect on such practices (Hooper-Greenhill 2000). It may, therefore, be timely to claim that absences are heavily ingrained in the meanings made with museum materialities, where practices, objects and absences come together in relational constellations, thus giving reason to view absences as part of museum materialities.

During my field study at Skógar museum I had come upon a floral picture when studying the exhibitions, searching for traces of disabled people. Its presentation was highly individualised as reflected in the museum text (in Icelandic) "Handiwork of a blind woman, Margrét Andrésdóttir from Berjaneskot, chairman of the Icelandic Association of the Visually Impaired." It was only when I spoke to a member of staff that I encountered other objects that had been made by, or belonged to, the same person that embroidered the floral picture, which is consistent with the experience of the researchers in the project Buried in the Footnotes (Dodd et al. 2004). These were scattered around the museum's exhibition halls and depositories without relevant mentions or contextualisation. Although we looked, objects pertaining to the lived lives and experiences of other disabled people, or traces of disabilities as part of the community in general, could not be found. It is relevant to note, that discussions with the staff member revealed that the issue of disabilities had not crossed her mind in relation to work at the museum nor had she considered that disabled people's stories should (or even could) belong among narratives about the museum's community. As it turns out, such an unawareness is common among museum staff and says more about persistent discourses circling in societies and institutional responsibilities than the orientations of individual staff members, a point I observe later in this section. What I want to note here is that these accounts mention disabled people and their disabilities (indeed, it could be argued that their stories are a definite presence of disabled people in museums). Yet, these stories contain absences where certain aspects are present but in a way that normalises well ingrained notions about disabilities and absences the manifold nuances that make up stories of lived lives.

As illustrated in the anecdotes above, Margrét "did numerous jobs like a seeing person," Ólafur challenged the ocean on a small fishing boat like "men with whole hands," and after losing her leg Guðrún "kept going and went straight to work as others who are completely healthy." In these accounts disabled people are there as confirmations of the norms of an able bodied society. In other words, they are included in their capacity to show the strength in the face of adversity: To overcome their shortcomings, 
to do what is expected of them, and only then in an overly medicalised and individualist fashion. These findings coincide with earlier studies of disabled people's histories and objects in museums, specifically the ways in which disabled lives and experiences are absenced with references to actions, always on behalf of disabled people themselves, that surmount disabilities (Dodd et al. 2004). Surmounting outmanoeuvres living and being when such an existence is subordinate in a hierarchical structure. The concept of overcoming legitimises social norms and shows that even the "weak" are strong and able to exercise bodily control so important to normative societies (Goodley 2013, p. 639). This can be construed as a form of compulsory able-bodiedness (McRuer 2006) infused with medicalisation and individualism (Shakespeare 2017) and persistent discourses ingrained in museum practices (Bergsdóttir 2016) that fail to traverse dichotomous notions of mind over matter and the elusive, yet violent, microaggressions that revolve around efficiency and hard work despite (as the discourse goes) the unruliness of bodies (Guðrúnar Ágústsdóttir et al. 2020, Loja et al. 2013).

These absences are not gap's that are noticed as differences between what is and is not present. They are subtle movements that shape a narrow lens through which the world is seen. This lens promises perfect vision but at the same time, it removes valuable aspects of lived lives and experiences leaving specific shapes (Dodd et al. 2004, Sandell and Dodd 2010). Such shapes speak to perspectives that assume able-bodied lives and experiences favourable (Pieri 2019) and are not maintained without reiterations of idealised notion about what is "normal" (Garland-Thomson 1997, McRuer 2006). The consequences of museum exhibitions and narratives need hardly be repeated but as argued in countless scholarships, museums have significant effects on societies and play an active role in shaping and contributing to social values and norms (Dodd et al. 2008, Janes and Sandell 2019, Macdonald 2012, Sandell 2007). The emphases on disabled bodies performing as able bodies as in the case of Ólafur, Margrét and Guðrún in the narratives at the beginning of this chapter seems no accident in this context. As Robert McRuer (McRuer 2006, p. 9) urges "Think, after all, of how many institutions in our culture are showcases for able-bodied performance."

Disabilities are unruly matters in museums. They defy traditional museum processes and evoke anxieties. As Anna Delin (2002) has pointed out, objects pertaining to the lived lives and experiences have all too often simply not been collected. If they are indeed there, they are buried in depositories and neglected. There is little evidence that this neglect is a consequence of deliberate actions on behalf of museum staff. However, the research Buried in the Footnotes found that there was an obvious need for general agreement, among staff members in the British museums surveyed in the study, on the importance of issues pertaining to disabilities and how these in fact mattered (Dodd et al. 2004). At the same time there is reason 
to speculate if museum staff are more inclined to engage with disabled people's histories and heritage when directed toward those issues. What I experienced in my study at Skógar Museum can only be described as a newly found interest on behalf of a staff member, which led her to eagerly participate in the mining for objects and registrations and even sending me copies of magazine articles and pictures of embroideries she had hunted down in homes in the museum's vicinity after I left. This willingness to engage has also been experiences in relation to similar case studies in Britain where the curators involved "dedicated time to think about their collection in light of the research" (Dodd et al. 2004, p. 9) and were inspired to find additional objects after visits from researchers.

Speaking to involvement or rather a lack thereof, Emma Chambers (2010) observes how curators fear insensitivity thus evading issues of disabilities rather than dealing with them. A common response would be to chalk such circumventions up to individual insecurities that have little to do with institutions, however such insecurities must speak to lack of support on behalf of the institutions in question (Sandell and Dodd 2010). In other words: Lack of responsibility, a term which is closely related to the concept of absencepresence and which I will return to later in this chapter. As Sara Ahmed (2012) has discussed in terms of racial diversity and institutions, they may want to venture beyond established practices. Yet, actual undertakings are likely to hit a wall composed of ingrained values and practices that have been deposited, through time, into a system focused on self-preservation. Such resistance, she argues, is "an expression of what the institution is willing to bring about," (Ahmed 2012, p. 129, Janes and Sandell 2019). This indifference seems to fall into the category of benign actions, an oversight or reckless indiscretion, yet it describes systemic oppression carried out by public institutions that, in the words of Sharon L. Snyder and David T. Mitchell, "continue to murder spirits" (2010, p. 122). This speaks to the neglect of absence, one that manifests in the actions of individual members of staff but framed and fertilised by institutional bureaucracies. It describes, as noted by Tanya Titchkosky (2011), how absence "is naturalised to such an extent that even when barriers and processes of exclusion are noticed they are still conceived as somehow natural, reasonable, sensible, and even seemingly justifiable" (p. 11). Her words speak to my concerns, because even if exclusions are acknowledged, absence itself is left unattended. There is a need to attend to absences, to recognise them and see them for what they are. But what are they?

\section{Matters of absence}

There seems to be an ingrained consensus to understand absences as nothings. They tend to be seen as negative spaces, gaps, or deficiencies and if they do, indeed, come into the purview of humans they are construed as nonthings (Fowles 2010). Seen through the lens of disabilities and museums 
it seems that absences have been relegated to a realm where their integrality and significance have been neglected. This is especially obvious when it comes to stories about lives and experiences that do not fit the generic voices of traditional museum narratives.

While it is widely accepted within current scholarship that museum processes generate narratives on histories and heritage that are less than inclusive, the absences produced by these very same processes have been of minimal concern. What is at stake are by all means displacements from public historical narratives. But also, the subtle absences that emerge from stereotypical framings like the ones mentioned above. Absences such as these have not gone unnoticed (Allday 2009, Sandell and Dodd 2010). But responses have predominantly aimed at rectifications: at adding to unabsence persistent absences by replacing them with things that are present. Such additive responses seem natural in a world that is enmeshed in persistent dichotomies. And they are imperative, as naming the nameless yields empowerment and the serenity for clear communication (Duggan and Hunter 2006), as well as offering clarity and concreteness to pressing concerns. Yet, what becomes lost is absence itself and the processes that create them.

Museum processes rest firmly on Enlightenment ideals that confine some bodies to the dark corners of pathological medicine. And although such bodies are no longer extraordinary spectacles at freak shows, they are extra, displaced, and silent (Garland-Thomson 1997). In other words, they are violently absent from public spaces. Such absences come to matter through complex webs of relationships: Through interconnections of cultures, bodies, spaces, ideologies, and practices, thus always already enmeshed in - and integral to - matters of disabilities. They do not need to be turned into presences, for absences are not hollow nothings - but they need to be trusted.

Before I speak of absences as relational matters, I would like to offer a few words on the importance of derailing the dichotomies that have shaped engagements with absences, and reconciling with the materialities of the world, as seen from the vantage point of disabilities and museums. The social construction of disabilities aptly shifted debates from the essentialist focus on bodies as extraordinary, pathological, and freakish spectacles (Garland-Thomson 1997) to an emancipatory view of disabilities as socially determined through tenacious discourses (Fine and Asch 1988, Jones 1996, Scheer 1994). This has been of significant value within cultural studies in elucidating both cultural essentialism and biological determinism (Lykke 2010). But whereas this radical turn was successful in uncovering covert power relations and shifting the focus from specific bodies to the disabling boundaries put in place by modern societies (Watson and Vehmas 2020) the de/constructive theories on which they build gradually forgot the materialities involved and the dynamic material/discursive relationships that 
make up worldly becoming's. This point has been taken up by scholarships that deal with subordinations of marginalised others (Kirby 2011, Lykke 2010). Among them, Stacy Alaimo and Susan Hekman (2008, p. 3) claim that the overt attention of de/constructionism towards language and social construction has, in fact, reiterated the very dichotomies they have sought to overcome.

Briefly aligning these concerns with museums and their representations gives reason to observe how these dichotomies are repeated through practices that, in general, characterise museums and their processes. Speaking to those directly, representations have served the purpose of contextualising museum materialities, particularly objects, in ways that reflect specific understandings of a reality, as it is perceived to exist outside the walls of traditional museums (Bjerregaard 2013). There seems to be a prevailing tendency to approach the tasks of representing by privileging discourse which reduces materialities to language and performance that tends to communicate specific understandings of the world. I do not mean to conflate the issue when I say that the representationalist paradigms that underpin traditional and hegemonic museum practices rest, in elementary terms, on the assumption that entities, including time and space, can be comprehensively reflected in removed circumstances. This approach favours that which can be seen and touched while neglecting absences, and while simultaneously giving impressions of integrity and wholeness. In this context I argue that the representational mode of museums reinforces the very dichotomies they need to overcome to actually work towards inclusivity. Within such frameworks, absences tend to be construed as a nonexistence rather than displacements, therefore forgotten as matters of the world that matter to the world.

When some matters fall prey to serial forgetfulness, it is critical to understand their absences as materialities. Here, Karen Barad's (Barad 2003, 2007, Dolphijn and Van der Tuin, 2012) agential realism is a valuable tool to think with as it allows entities to become relevant, to matter, through dynamic relationships in and of the world. Agential realism is an approach that aligns with the frameworks of posthumanism and new materialism that underline the importance of bringing materialities back into view without falling prey to essentialist notions (Lykke 2010), traversing persistent dichotomies (Alaimo and Hekman 2008), and allowing for shared connections that allow for surprising matterings that involve an array of possibilities (Barad 2007, Haraway 1992, 2008). Whereas matter is generally understood as passive, fixed and subject to human interpretation, at least within the realm of de-/constructionism, agential realism involves an onto-ethicoepistemological approach (Barad 2007) that reformulates the concepts of matter as agentic and active and based on their connections. These connections are mutual and intra-active, a term which indicates how these relationships are made. Matters, in this sense, are not pre-existing, entities 
that link with one another but come into being through relationships within entities. Whereas agencies are always enactments, intra-acting agencies iteratively produce configurations of entanglements. These configurations speak to specific understandings about difference and how difference is iteratively reconfigured and "made." Whereas pre-existence signals that connections are individualistic enterprises that happen between entities, intra-actions spell out the inseparable intra connectedness of entities, specifically those of matter, meaning and, important to this chapter's concerns, ethics.

Conceptualising objects, knowledge and ethics as dynamic configurations that contribute to the world's becoming's cuts across debates and challenges the dualisms entrenched in the humanities by offering perspectives that cut across those imagined boundaries. In this light, absence and presence cannot be viewed as separate entities. Rather, I argue, absence needs to be trusted as part of the world's materialities that is always already entwined with presence in mutually affected, dynamic relationships: In absencepresence (Bergsdóttir and Hafsteinsson 2018).

\section{Absencepresence}

Approaching absences as matters calls for fundamental reworkings of the presence/absence dichotomy. If the persistent absences of disabled bodies are to come to matter, as significant entities that tie to relevant issues and exclusionary systems, the benefits of viewing them as separate entities are limited. Disabilities are everywhere, as Rosemary Garland-Thomson stated (2014), and so are absences. Yet, they cannot be dismissed as nothings, for absence and presence are entangled becoming. They are performances that emerge as understandings and inform narratives, but without detection. After all, if something is construed as nothing, it is understood as undetectable. It is therefore that I argue that the violent absences of disabled people in histories and heritage and the subtle absences that support stereotypical depictions of such stories come to matter through the lens of absencepresence (Bergsdóttir and Hafsteinsson 2018).

As I have discussed earlier in this chapter, maintaining the disengagement of absence and presence also preserves normative narratives where unruly features of lived lives and experiences are removed from sight or disabled bodies are excluded completely. Narratives that exclude features systematically deemed as unruly, forgotten stories, objects that have not been collected, museum professionals that are (often inadvertently) challenged by persistent social and institutional discourses, an overt focus on constructionist frameworks, and the representational modes that govern traditional museum practices, have been shaped by a divide that allows see-able and touch-able entities to be instilled with significance and meaning while absences get lost in an abyss of irrelevance. Yet, absences are far from irrelevant. Their shaping's, I argue, and the violent absencings that occur in their 
wake, are imperative to the histories and heritage of those that are excluded. This cannot be rectified by simple and swift presencings. Although I will reiterate that looking for disabilities is an essential gesture, I want to remind us that such gestures cannot function to absence these exclusionary systems and their implications. Rather, they are difficult yet valuable stories that trouble normative narratives and the practices that create them, and they call for responsibilities and care.

\section{Absencepresence and matters of responsibility}

It is important to discuss responsibility in terms of relational matterings, such as those framed by agential realism as it lies at the heart of understandings of absencepresence as a relational entity valuable for the manifold relationships between disabled people's histories and museums and institutions. Recognising absences as part of human entanglement in and of the world is a question of ethics and signals how museums are ethically bound co-creators of matter. Also, it underlines the urgency for different tools to think museum practices with, that trouble the perceived neutrality of museums. It sparks unruliness within institutions that have become used to creating and representing narratives with an ingrained promise of wholeness and perfect vision (Haraway 1988); It questions collections and institutional walls of ingrained values and practices that nurture professional insecurities (Ahmed 2012, Chambers, 2010). But why then, does it not entail responsibility when museums take action by adding disabled people's stories to existing narratives? First, adding excluded stories would constitute reactions to wrongs that museums need to put right. These are not, however, responsibilities on part of museums. As implied in the term itself, responsibility entails responses, not reactions. It is a question of becoming with (Haraway 2010) in ways that are ethical (Åsberg 2013) through practices of reciprocal relationships that "make us responsible in unpredictable ways for which worlds take shape" (Haraway 2008, p. 36). Second, responsibility is not a separate entity that can be added on nor are they motives that spur sporadic actions. Responsibility is not even an attribute solely within the grasp of humans to be applied whenever deemed fit. Responses can come from a variety of entities, human and nonhuman, that enter into reciprocal relationships. Rather, responsibility and ethics are always already entwined in and of the relationships that draw specific entanglements: specific matters, to the fore. As Haraway explains, they are "crafted in intra-action through which entities, subjects, and objects come into being" (2008, p. 71). Processes that disregard certain bodies, lives and experiences in museums do so through exclusions: by presence-ing certain elements while absence-ing others. Responsibility, according to Barad (2007, Dolphijn and Van der Tuin 2012) is not an individual affair but extends to the entangled others. Thus, it comes into play who is excluded and who is not. In other words, engaging with stories about 
a prosthetic hand, needlework crafted by a blind woman, stories about a girl who lost her leg while ice skating or whichever stories may emerge, prompts museums to respond to such stories in ways that are shaped by their practices. In other words, it is the enactments that museum practices allow that shape stories, not careful and responsible consideration of the almost infinite possible possibilities inherent in these specific histories or heritage.

\section{Discussion}

Since, in a world where able bodies are the norm and a prerequisite for being fully included as citizens (Snyder and Mitchell 2010) there seems to be a general demand, even obligation, to fit well with the world (GarlandThomson 2011) as it is understood in its normalised character. Like the sisters, in the fairy-tale of Cinderella, whose feet were whittled into shape to fit into a crystal shoe that promised them inclusion and social standing in the world, people, places, objects, cultures, genders, abilities, and uncomplying ways of being (McRuer 2006) are made to fit by eliminating and overlooking components that seem to stand in the way of complete deference to the world as it is materially and discursively constructed at each time. Also, rather than reiterating the long-standing practices of finding and speaking for dis-/abled people in cultural representations, it contributes to discussions that aim at traversing the dichotomies that are ingrained in the cultural politics of heritage and institutions, such as museums. Therefore, we must recognise absence as absence - as matters that matter. They must be owned by institutional entities and political systems so that cracks can be noticed, and wrongs can be put right. This does not mean that absences should prevail over the histories and heritage of disabled people - that we should stop looking for material evidence of disabled lives - but they should be recognised as material entities among other material entities. As stories among stories. It is imperative to name absences so they can become part of such stories. To recognise them and care for them as matters that matter. But this may be hard. Recognising absences as matters that matter may involve difficult and complex feelings of grief, anger, rejection, and guilt. Absencepresence is a critical tool to think with as it allows for the double move of analysing how knowledge is created and of creating alternative understandings enmeshed with epistemological, ontological, and ethical concerns. There is no innocence in stories such as the ones about Ólafur, Margrét, and Guðrún exemplified at the beginning of this chapter. These are depictions and representations created by museums and involve imperative absencepresences. The aim must be to recognise such matters, but at the same time, recognise the unjustness of systems, institutions and the normalising tendencies ingrained in various technologies and practices. That has to be part of the 
stories that are told. As we are reminded by Donna Haraway (Haraway 2016, p. 12):

It matters what stories we tell to tell other stories with; It matters what knows knots knot knots, what thoughts think thoughts, what descriptions describe descriptions, what ties tie ties.

\section{References}

Ahmed, S., 2007. The language of diversity. Ethnic and Racial Studies, 30 (2), 235-256.

Ahmed, S., 2012. On being included: Racism and diversity in institutional life. Durham, NC: Duke University Press Books.

Alaimo, S., and Hekman, S., 2008. Introduction: Emerging models of materiality in feminist theory. In: S. Alaimo and S. Hekman, eds. Material Feminisms. Bloomington: Indiana University Press, 1-22.

Allday, K., 2009. From changeling to citizen: Learning disability and its representation in museums. Museum \& Society, 7 (1), 32-49.

Åsberg, C., 2013. The timely ethics of posthumanist gender studies. Feministische Studien, 31 (1), 7-12.

Azoulay, A. A., 2019. Potential history. Unlearning imperialism. London: Verso.

Barad, K., 2003. Posthumanist performativity: Toward an understanding of how matter comes to matter. Signs, 28 (3), 801-831.

Barad, K., 2007. Meeting the universe halfway: Quantum physics and the entanglement of matter and meaning. Durham, NC: Duke University Press Books.

Barad, K., 2012. No099: Karen Barad. What is the measure of nothingness? infinity, virtuality, justice. Ostfildern, Germany: Hatje Cantz Verlag.

Basu, P., 2017. The Inbetweenness of things. Materializing mediation and movement between worlds. London: Bloomsbury Academic.

Bergsdóttir, A., 2016. Museums and feminist matters: Considerations of a feminist museology. NORA-Nordic Journal of Feminist and Gender Research, 24 (2), 126-139.

Bergsdóttir, A., 2017. Absence comes to matter. Entangled becomings of a feminist museology. Thesis (PhD). University of Iceland.

Bergsdóttir, A., and Hafsteinsson, S. B., 2018. The fleshyness of absence. The matter of absence in a feminist museology. In: W. Grahn and R. J. Wilson, eds. Gender and heritage. Performance, place, and politics. London: Routledge, 99-112.

Bjerregaard, P., 2013. Assembling potentials, mounting effects: Ethnographic exhibitions beyond correspondence. In: C. Suhr and R. Willerslev, eds. Transcultural montage. Oxford: Berghahn, 243-261.

Bodo, S., 2012. Museums as intercultural spaces. In: R. Sandell and E. Nightingale, eds. Museums, equality, and social justice. New York: Routledge, 181-192.

Chambers, E., 2010. Face to face: Representing facial disfigurement in a museum context. In: R. Sandell, J. Dodd, and R. Garland-Thomson, eds. Re-presenting Disaiblity. Activism and Agency in the Museum. London: Routledge, 179-194.

Delin, A., 2002. Buried in the footnotes: The absence of disabled people in the collective imagery of the past. In: R. Sandell, ed. Museums, Society, Inequality. London: Routledge, 84-97. 
Dodd, J., Sandell, R., Delin, A., and Gay, J., 2004. Buried in the footnotes. The representation of disabled people in museum and gallery collections - Phase 1 report. Leicester, UK: Research Centre for Museums and Galleries.

Dodd, J., Sandell, R., Jolly, D., and Jones, C., eds., 2008. Rethinking disability representation in museums and galleries. Leicester: Research Centre for Museums and Galleries.

Dolphijn, R., and Van der Tuin, I., 2012. "Matter feels, converses, suffers, desires, yearns and remembers". Interview with Karen Barad. In: G. R. Dolphijn and I. Van der Tuin, eds. New materialism: interviews \& cartographies. Ann Arbor, MI: Open Humanities Press.

Duggan, L., and Hunter, N. D., 2006. Sex wars. Sexual dissent and political culture. New York: Routledge.

Fine, M., and Asch, A., 1988. Disability beyond stigma: Social interaction, discrimination, and activism. Journal of Social Issues, 44 (1), 3-21.

Fowles, S., 2010. People without things. In: M. Bille, F. Hastrup, and T. F. Sørensen, eds. An anthropology of absence. Materializations of transcendence and loss. New York: Springer, 23-44.

Garland-Thomson, R., 1997. Extraordinary bodies. Figuring physical disability in American culture and literature. New York: Columbia University Press.

Garland-Thomson, R., 2011. Misfits: A feminist materialist disability concept. Hypatia, 26 (3), 591-609.

Garland-Thomson, R., 2014. Gender and disability in visual culture. Fötlun og menning. Mannréttindi hversdagsins, 28 March 2014 Reykjavík. Reykjavík: The Icelandic Disability Alliance.

Gaskell, I., 2012. Museums and philosophy-of art, and many other things part I. Philosophy Compass, 7 (2), 74-84.

Goodley, D., 2013. dis/entangling critical disability studies. Disability \& Society, 28 (5), 631-644.

Guðmundsdóttir Eydal, R., 2020. Hnifar og hakjur. Thesis (MA). University of Iceland.

Guðrúnar Ágústsdóttir, E., Jóhannsdóttir, Á., and Haraldsdóttir, F., 2020. Öráreitni og ableismi: Félagsleg staða ungs fatlaðs fólk í almennu rými. Íslenska Pjóðfélagið, 11 (2), 3-18.

Haraway, D., 1988. Situated knowledges: The science question in feminism and the privilege of partial perspective. Feminist Studies, 14 (3), 575-599.

Haraway, D., 1992. The promises of monsters: A regenerative politics for inappropriateld others. In: L. Grossberg, C. Nelson, and P. A. Treichler, eds. Cultural Studies. New York: Routledge, 295-337.

Haraway, D., 2008. When species meet. Minneapolis: University of Minnesota Press. Haraway, D., 2010. When Species meet: Staying with the trouble. Environment and Planning D: Society and Space, 28, 53-55.

Haraway, D., 2016. Staying with the trouble. Making kin in the chthulucene. Durham, NC: Duke University Press.

Hooper-Greenhill, E., 2000. Museums and the interpretation of visual culture. London: Routledge.

Janes, R. R., and Sandell, R., 2019. Posterity has arrived: The neccessary emergence of museum activism. In: R. R. Janes and R. Sandell, eds. Museum Activism. London: Routledge, 1-22. 
Jones, S. R., 1996. Toward inclusive theory: Disability as social construction. NASPA Journal, 33 (4), 347-354.

Kinder, J. M., 2014. "Lest we forget." Disabled veterans and the politics of war remembrance in the United States. In: S. Burch and M. Rembis, eds. Disability Histories. Chicago: University of Illinois Press.

Kirby, V., 2011. Quantum anthropologies: Life at large. Durham, NC: Duke University Press.

Loja, E., Costa, M. E., Hughes, B., and Mendez, I,. 2013. Disability, embodiment and ableism: Stories of resistance. Disability \& Society, 28 (2), 190-203.

Lykke, N., 2010. Feminist studies: A guide to intersectional theory, methodology and writing. New York: Routledge.

Macdonald, S. J., 2012. Museums, national, postnational and transcultural identities. In: B. M. Carbonell, ed. Museum studies: An anthology of contexts. 2nd ed. Malden, MA: Wiley-Blackwell.

McRuer, R., 2006. Crip theory. Cultural signs of queerness and disability. New York: New York University Press.

McRuer, R., 2018. Crip times. Disability, globalization, and resistance. New York: New York University Press.

Olsen, B., and Svestad, A., 1994. Creating prehistory. Archaeology museums and the discourse of modernism. Nordisk Museologi, 1, 3-20.

Ott, K., 2005. Disablity and the practice of public history: An introduction. The Public Historian, 27 (2), 9-24.

Ott, K., 2018. Material culture, technology, and the body in disability history. In: M. Rembis, C. Kudlick, and K. E. Nielsen, eds. The Oxford handbook of disability history. Oxford: Oxford University Press, 125-140.

Pieri, M., 2019. The sound that you do not see. Notes on queer and disabled invisibility. Sexuality \& Culture, 23, 558-570.

Preziosi, D., 2012. Narrativity and the museological myths of nationality. In: Carbonell, B. M., ed. Museum studies: An anthology of contexts. 2nd ed. Malden, MA: Blackwell Publishing.

Ray, S. J., and Sibara, J., 2017. Introduction. In: S. J. Ray and J. Sibara, eds. Disability studies and the environmental humanities. Towards and eco-crip theory. Lincoln, NE: University of Nebraska Press, 1-28.

Sandell, R., 2007. Museums, prejudice and the reframing of difference. Abingdon: Routledge.

Sandell, R., and Dodd, J., 2010. Activitst practice. In: R. Sandell, J. Dodd, and R. Garland-Thomson, eds. Re-presenting disability. Activism and agency in the museum. London: Routledge, 3-22.

Sandell, R., \& Nightingale, E., eds., 2013. Museums, equality and social justice. London: Routledge.

Schalk, S., 2018. Bodyminds reimagined. (Dis)ability, race and gender in black women's speculative fiction. Durham, NC: Duke University Press.

Scheer, J., 1994. Culture and disability: An anthropological point of view. In: E. J. Trickett, R. J. Watts, and D. Birman, eds. The Jossey-Bass Social and Behavioral Science Series. Human Diversity: Perspectives on People in Context. San Fransico: Jossey-Bass/Wiley, 244-260.

Shakespeare, T., 2017. The social model of disability. In: L. J. Davis, ed. The disablity studies reader.5th ed. New York: Routledge, 195-203. 


\section{A. Bergsdóttir}

Snyder, S. L., and Mitchell, D. T., 2010. Introduction: Ablenationalism and the geo-politics of disability. Journal of Literary \& Cultural Disability Studies., 4 (2), $113-125$.

Titchkosky, T., 2011. The question of access. Disability, space, meaning. Toronto: University of Toronto Press.

Watson, N., and Vehmas, S., 2020. Disability studies: Into the multidisciplinary future. In: N. Watson and S. Vehmas, eds. Routledge Handbook of Disability Studies. London: Routledge, 3-13. 


\title{
7 Health, Healing, and the Social Body in Medieval Iceland
}

\author{
Christopher Crocker and Yoav Tirosh
}

\section{Introduction}

For good reason, activists and scholars have long advocated for an understanding of disability beyond its traditional modern conceptualisation as an individual problem that could only be solved - or remain unsolved following medical intervention (Shakespeare 2014, Beaudry 2016, Sigurjónsdóttir and Rice in this volume). The consequent emergence of disability studies as an academic discipline saw the rejection of a strictly medicalised conceptualisation of disability, focusing instead on how atypical bodies and minds are subject to myriad social, political, cultural, and economic factors as well as an impetus for cultural production. However, some scholars have challenged approaches to the subject that seem to repudiate any exploration of the physiological dimensions of disability. Shakespeare (2014) for example, has suggested that "health needs of disabled people are rarely taken into account in disability studies" (p. 83) and that the "[f]ailure to meet general or impairment-related health needs is itself a disabling barrier" (p. 83). Following this line of thought, those who make use only of those theorisations that regard disability and health concerns as mutually exclusive issues run the risk of obscuring crucial interactions and intersections between the two.

Scholars exploring disability in the premodern past, while commonly adopting a predominantly socio-cultural approach, are perhaps more easily able to avoid disregarding such interactions and intersections. This is so not because medical care is an entirely modern innovation but rather due to the modern phenomenon of siloing knowledge systems resulting in the tendency to ideologically constitute scientific understanding, including medical science, as utterly distinct from or, sometimes, as directly opposed to other discourses regarding the body. During the Middle Ages, for example, common conceptualisations of the body were frequently physiological but also simultaneously incorporated emotional, legal, moral, mythological, paranormal, theological, and other dimensions (Horden 2009, Frog 2019, Hartnell 2019). Thus, scholars who adopt an approach inspired by a disability studies perspective when examining matters of health, illness, and 
healing care during this period are arguably better equipped than those working within the confines of a traditional history of medicine approach, particularly when dealing neither with physical evidence nor with source material that assumes a decidedly medical register.

With this in mind, the present chapter deals with issues of health, illness, and healing care in medieval Iceland, particularly as expressed through the prism of the Íslendingasögur (Sagas of Early Icelanders). This collection of texts, dating to the 13th, 14th, 15th centuries, constitutes a literary form of history mediated through oral traditions, which combines inherited cultural memories with creative historical interpretations of the past (Jakobsson 2015, Crocker et al. in this volume). These sagas are valuable sources regarding prevailing, but also variable, ideologies and mentalities concerning health, illness, and healing care in medieval Iceland. Bodies or minds perceived to be healthy in the sagas, and consequently also their unhealthy counterparts, are not only represented as physiological phenomena but are also as reflections of a variety of socio-cultural factors. This is exemplified in the Old Icelandic terms heill and heilsa, which refer to both "health" and to "wholeness," with the later sense of the term encompassing not only physiological wholeness but also the ability to fulfil one's prescribed social role. As such, health, illness, and healing care in the sagas are best explored not only as individual but as social phenomenon as well. The unhealthy body in particular either provokes or fails to provoke a variety of actions or responses from the community and, thus, operates as a medium through which aspects of the body's inevitably social nature become evident.

\section{Healing the body}

In contrast to the case-specific insights provided by the surviving premodern physical evidence (Collins 2018, Hoffman 2019, Haraldsson in this volume, Kristjánsdóttir and Walser III in this volume) or handbooks listing specific treatments for different kinds of illnesses (Larsen 1931), the medieval sagas refer to a broader awareness of both practical and theoretical understandings of the body and are concerned with how this knowledge was applied, as well as who had access to this knowledge and practice. Attempts to draw distinctions, for example, between certain healing practices such as learned observations, divine intervention in the form of saintly miracles, and religio-magical practices may have existed in the medieval North (Simek 2019, McDougall 1992, Whaley and Eliot 1994). Yet, surviving written sources suggest that matters concerning health, illness and healing care were often simultaneously mediated through foreign medical doctrines, corresponding folk traditions, religious beliefs, ideas about emotions, and perceptions of the paranormal.

A text found in the early 14th century manuscript known as Hauksbók, for example, bears the title "Af natturu mannzins ok blodi" (On the nature 
of man and blood). It contains a short summary of humoral theory, which originated in antiquity and was widely circulated throughout the Middle Ages, that suggested one's general disposition, health, and emotions were determined by a balance or imbalance of certain bodily fluids, which could also be subject to change as one ages (Jónsson and Jónsson 1892-96, p. 181-82). The physiological portion of the text, which may be an Old Icelandic translation deriving from a medieval Latin text known as Epistula Vindiciani (Vindician's letter), is preceded by a tract on God's creation of the world, aspects of its nature, climate, and geography, culminating with the creation of Adam (Jónsson and Jónsson 1892-96, p. 180-81, Porgeirsdóttir 2018, p. 51-60). The arrangement of the text, which makes a seamless transition between theological and physiological or medical ideas, indicates that the two are intended to be seen as intimately connected and even inseparable from one another. References to and perhaps more subtle echoes of humoral theory have also been detected in several other medieval Icelandic texts, including some of the more well-known sagas.

Scholars have argued, for example, that versions of Egils saga SkallaGrímssonar, Fóstbraðra saga, and Bandamanna saga, among other sagas, include passages that suggest a familiarity with traditional humoral theory by way of imported Latin literary influence (Reichborn-Kjennerud 1936, p. 20-26, Lönnroth 1965, Kristjánsson 1972, p. 240-47, Høyersten 1998, Tirosh 2014, Høyersten 2015, Kanerva 2015, p. 111-13, Porgeirsdóttir 2018, p. 49-50). However, some have countered this claim, or at least claims about the magnitude of foreign influence on ideas concerning health, illness, and healing in Iceland during the Middle Ages (Hallberg 1965, Kanerva 2015). Kirsi Kanerva (2015), for instance, has emphasised the persistence in medieval saga writing of folk traditions concerning health, illness, and healing in medieval Iceland, which were inseparable from moral or religious matters, emotional practices, and encounters with the paranormal (Erlingsson 1996, Hall 2009, Kanerva 2013, Kanerva 2014, Porgeirsdóttir 2015). More than this, as mentioned above, the body in the sagas - including its perceived unhealthy or un-whole forms - is a social phenomenon, which can be illustrated using a striking example from the aforementioned Egils saga Skalla-Grimssonar.

In a brief anecdote in the saga, a kona sjúk (ill woman) named Helga Porfinnsdóttir becomes bedridden but unable to sleep. Helga and her condition are variously described using the terms pungliga haldin (very ill), hamstoli (crazed), langan vanmátt (long waning strength), and kröm mikil (great wasting disease). At her father's request, the saga's poet protagonist Egill offers to help. He first advises that her bedclothes be changed, whereupon he discovers runes carved on a whalebone had been placed under her bed. Helga's father suggests that these runes were placed there by the son of a neighbouring farmer as an attempt to heal Helga's's illness. Egill casts the whalebone into the fire, while he simultaneously chastises in verse those who engage in such practices without having the proper knowledge 
to do so. He then places carved runes of his own under the bed. After only a short time a rapid change comes over Helga and she claims that she "var pá heil, en pó var hon máttlítil" (was now healthy, although she had little strength). Both Egill and the narrative quickly move on, but sometime later, when Egill returns to the same farm, the saga relates that "Helga ... var pá á fótum ok heil" (Helga ... was then on her feet and healthy) (Nordal 1933, p. 229-30). In the meantime, it had come out that the man who had carved the runes Egill had thrown into the fire intended to seduce Helga, but his lack of knowledge had led to her become ill instead.

The saga is somewhat equivocal about the cause of Helga's illness. Its onset initially seems to precede but might also be a consequence of the runes carved by her unwelcome suitor. In any case, her illness and its treatment are connected to both emotions and specialised or esoteric knowledge. Physical evidence attests to the reality in the medieval North of the use of runic carvings to deal with illnesses and healing (Jesch and Lee 2020). Yet, the narrative construction of Egill's intervention may have also been influenced by scriptural and hagiographical narrative traditions (Grønlie 2017, p. 88-90). In fact, rather than the specific details of the treatment he provides, the focus is firmly placed on him possessing such rare knowledge and not on the details of the knowledge itself. Moreover, the saga relates how Helga's father compensates or rather reciprocates Egill not only through the hospitality he provides, but also by accompanying him and his companions as they travel through hostile territory (Nordal 1933, p. 229-31). Egill's well-timed application of his specialised knowledge can be read as an extension of gift-giving practices common in medieval Iceland and Scandinavia (Pálsson 2015, Sigurðsson 2017, Barriero forthcoming). In this instance, his knowledge functions as a reciprocal good that can be shared and, through its sharing, it establishes a meaningful homosocial bond between the two men.

This brief anecdote, culminating with Helga's return to heil( $l$ ) (health or wholeness) underscores how matters concerning health, illness, and healing care in medieval saga writing frequently concern more than the individual body. Whether originally caused or only exacerbated by the actions of her unwanted suitor, Helga's illness or, indeed, un-wholeness is explicitly connected to the threat of an unwanted and illicit love affair. Furthermore, although the saga makes no further mention of Helga beyond this point, the emphasis placed on this aspect of her illness seems to suggest that her return to heil(l) likely also coincides with a revived opportunity for Helga and her family to establish new social bonds through marriage with a more appealing suitor (Schulman 1997, Karras 2003). It is also worth noting that Egill's crucial intervention was not, however, that of a sought after professional but of a man possessing the required specialised skills who happened to be in the right place at the right time. Yet, his specialised skills also require the availability of unhealthy bodies to prove their efficacy and value. Although the saga provides no insight toward the motivation 
behind Egill's actions, the way Helga's father compensates him falls entirely within the reciprocal culture depicted throughout medieval saga writing. Ultimately, though contingent upon the presence of an unhealthy body, this brief episode is as much or arguably even more interested in the broader social actions that encompass the events than with the specific details of Helga's illness and her individual experience of the ordeal.

\section{The whole body}

An episode found in Fóstbraðra saga, one concerning the poet bormóðr Bersason, similarly stresses how illnesses in the sagas function as a lens through which aspects of social nature of the body become visible. The episode begins when Pormóðr is visited in a dream by a woman named porbjorg kolbrún (coal-brow) for whom he had composed a series of flattering verses. In the dream, Porbjorg chastises bormóðr for reworking and rededicating the verses to a woman named bórdís. She threatens to inflict severe augnaverkr (eye-pain) upon him, such that his eyes will burst out of his head and tells him that he will "aldregi heill verða" (never be heill again) (Pórólfsson and Jónsson, 1943, p. 174-177), unless he publicly admits to his transgression and returns the verses to their original form. Sure enough, Pormóðr awakens with severe pain in his eyes prompting his father Bersi to remark aphoristically "Eigi er sá heill, er í augun verkir" (One is not heill, who has pain in his eyes) (Pórólfsson and Jónsson, 1943, p. 174-177). Bersi advises Pormóðr to heed the warning and also reminds pormóðr of an earlier wound he had suffered. That wound, which rendered him orvendr (left-handed) for the rest of his life, followed his previous seduction of the same Pórdís, whose favour he had tried to win back by rededicating the verses to her. Echoing, but also somewhat contradicting Porbjorg's warning, Bersi suggests that his son already "verðr aldri heill maðr" (will never be a healthy man again) (Pórólfsson and Jónsson, 1943, p. 174-177), not only if he fails to reverse the course of his eye-pain but also on account of his earlier wound.

In any case, when Pormóðr returns the verses to their original form and again dedicates them to Porbjǫrg, the saga states that "verðr hann pá alheill pess meins" (he then fully recovered from this injury) (Dórólfsson and Jónsson 1943, p. 174-77). More than simply a physiological phenomenon, however, in this and many other instances in medieval saga writing, the onset of augnaverkr (eye-pain), frequently following the experience of a paranormal dream, is commonly connected to various kinds of perceived moral transgressions, whether interpersonally, socially, or spiritually (Kanerva 2013, Crocker 2019, p. 42-50, Crocker 2020). Pormóðr's transgression seems to relate to his fickleness and promiscuity, reflecting his perceived "socially abnormal relationships with women" (Merkelbach 2019, p. 85). Although his augnaverkr is quickly alleviated, the likely loss of vision, and perhaps also the facial disfigurement he would have experienced had he not met 
Porbjorg's demands, would likely serve as visible markers of his moral turpitude. Thus, the saga seems to suggest that, in medieval Iceland, otherwise unexplained eye injuries and ensuing visual impairments could be regarded not only as discernible physiological differences but also as manifestations of their bearer's flawed moral character, which could invite social stigma or other prejudicial treatment.

As in the example from Egils saga Skalla-Grimssonar, the concept of heill encompasses more than the strictly physiological in this episode. Pormóðr's father uses the term when he tells his son that he will never be heill (healthy or whole) again in reference to an injury the lasting effect of which was the loss of manual dexterity in his right arm or hand. John Sexton $(2010,2020)$ contends that assessments of permanently injured male bodies in the sagas are not always constituted as "a permanent redefinition of the injured person," whether conveyed through the same phrase Dormóðr's father uses or, for example, a term such as óvigr (unable to fight) (p. 155-56). Furthermore, Edna Edith Sayers, published as (Bragg 2004), argues that, rather than negative social stigma, such injuries could also be read as "the proud tokens of ... properly reckless battle conduct," at least in some instances (Bragg 2004, p. 92, p. 241-42, Sexton 2010, p. 154-57, Künzler 2016, p. 259-65). Yet, in Pormóðr's case, as in several others, there is little evidence in the text, beyond the brief exchange he shares with his father, to determine how Pormóðr and the society around him made sense or interpreted his enduring "un-wholeness" in the context of the martial society depicted in the sagas.

The perhaps conspicuous silence surrounding Pormóðr's injury in its immediate aftermath and the loss of manual dexterity that follows may, on the other hand, reflect a broader cultural inability to properly address and verbalise the individual and collective trauma that pervades the violent society depicted in medieval saga writing (Heiniger 2020, Tulinius 2018a, Tulinius 2018b, Poilvez 2020). With this in mind, it is worth mentioning that the slave, Kolbakr, who had inflicted the wound on Pormóðr at Pórdís's mother Gríma's behest, is outlawed but manages to escape from Iceland. The saga makes a point to explain that bormóðr never received "meiri sæmð síns áverka en sekðir Kolbaks" (more redress for his injury than Kolbakr's conviction) (Pórólfsson and Jónsson 1943, p. 169). Thus, more than just a physical difference, the injury acts as a lasting mark of Pormóðr and his father's shame for having failed "to extract justice from a woman householder and her slave" (Bragg 2004, p. 226). Still, despite several reminders and expressions of his own sense of self-doubt, the narrative suggests that Pormóðr's lasting injury can ultimately be redefined in a way that renders him capable of living out a traditional hero's arc. This redefinition, however, does not follow any physical change but rather results from an encounter with a man named Gestr, a mysterious and seemingly Odinic figure, as well as Pormóðr's entry into the saintly King Óláfr helgi’s service (Bragg 2004, p. 231-33, Grønlie 2017, p. 236-43, Merkelbach 2019, 
p. 86-89). Keeping this in mind, it is likely no coincidence that Pormóðr's final act in the narrative is to die in battle while heroically defending a group of injured warriors in a barn that has been turned into a makeshift field hospital.

Returning to the aftermath of Pormóðr's dream encounter with Porbjorg, it is worth recalling that his primary identity in the saga is not as a warrior but as a poet, as encoded in his nickname kolbrúnarskáld (coal-brow's poet). His "verbal acuity" has, in fact, been interpreted as a kind of compensation for his permanently injured body (Bragg 2004, p. 232). Even if such an interpretation risks overreading that aspect of the saga, the eye-pain, and the threat of vision loss that Porbjorg inflicts upon him is much more than just a physical threat. As mentioned above, it could simultaneously serve as an outward marker of Pormóðr's morally flawed character. Even more than this, the episode illustrates that Pormóðr's body is deeply entangled with his social identity and public role as a poet. Although blindness or vision loss in literature sometime takes on a symbolic meaning in the context of poets possessing inner vision and being able to "see" what others cannot see, such symbolism is not present in Fóstbraðra saga. Instead, Pormóðr's state of heill (health or wholeness) reflects his public status as a poet and both become compromised when he violates the perceived norms of the profession. The public nature of this compromise is further underscored by the fact that Porbjorg demands not a private apology but a public admission of both the wrong he has done and a rededication of the verses he had originally composed in her honour.

\section{The social body}

In another saga, Vápnfirðinga saga, both health and access to healing care are also major components in the narrative's construction such that - to an even greater degree than the previous examples - the social nature of the body emerges as one of the saga's central, recurring motifs, only a few representative examples of which can be explored at present. After beginning by recounting a few of the exploits of a young Brodd-Helgi porgilsson, the saga focuses primarily on the relationship he shares with Geitir Lýtingarson and, later, the complex relationship between their sons Porkell Geitisson and Bjarni Brodd-Helgason. Geitir and Brodd-Helgi are childhood friends from the North-East of Iceland who grow to become powerful men in the region and consolidate their friendship through a marriage between Brodd-Helgi and Geitir's sister Halla. Eventually, however, Geitir and Brodd-Helgi's relationship turns sour following a financial dispute, which coincides with Halla's health taking a turn to the worse. There is no explicit indication that the onset of Halla's vanheilsa (waning health, or perhaps chronic illness) is a result or symbolic reflection of the withering of her husband and brother's close friendship, but the correlation between the two events is slightly conspicuous. 
In any case, when Halla makes Brodd-Helgi aware of her illness, he makes overtures of love and assures her that he will remain with her "meðan okkart líf vinnsk" (until the end of our lives) (Jóhannesson 1950, p. 36). Yet, despite these theatrics, he quickly finds a new, younger, and presumably healthier wife named Porgerðr silfra (silver). Halla is therefore denied the love and care of her husband due to her illness, but the narrative also makes clear that Brodd-Helgi's behaviour was viewed negatively by the people of the district due to Halla's popularity. A husband whose wife was grievously ill was clearly expected to stay by her side, a duty that Brodd-Helgi's fails to carry out. However, one day when her brother Geitir is away from home, Halla sends for Helgi to come visit her. Upon his arrival, "Hon bað hann, at hann skyldi sjá meinit. Hann gerði svá, ok kvazk honum pungt hugr um segja. Hann hleypir út vatni miklu ór sullinum, ok varð hon máttlítil eptir petta" (She asked him to have a look at her sore. He did this, and said it seemed a grave matter indeed. He pushes much water out of the boil, and she became exhausted after this) (Jóhannesson 1950, p. 44). Halla then asks Brodd-Helgi to stay for the night, but he refuses. She scolds him for the way he has treated her, after which he leaves, and a few days later, she dies. Following Halla's death, the friendship between Brodd-Helgi and Geitir is irreparably dissolved. Sometime after this, Brodd-Helgi is killed, either by Geitir or more likely one of his men, with the killer's precise identity missing in the extant manuscripts of the saga.

As with the cases of Helga who is successfully healed by Egill, the promiscuous poet bormóðr, and that of Halla and Brodd-Helgi, whose treatment is less successful than Egill's, sagas often put a spotlight on health and illness in interactions involving love. In Bjarnar saga Hitdœlakappa, for example, Pórðr Kolbeinsson vanquishes his long-time foe Björn in battle, afterwards cutting off his head. The gloating Pórðr informs his wife Oddný, who had been having an affair with Björn, of the death, and presents her with her decapitated lover's necklace. Oddný does not take this news very well, and collapses when she sees the necklace, and is afterwards like Halla - struck with mikil vanheilsa (severely waning health, or perhaps chronic illness) from which she never recovered. Her death, however, is not imminent, but the narrative stresses that she lost all joy in life and mourned Björn until the end of her surprisingly long life. Yet, bórðr goes to great lengths to help his wife through her mental and physical anguish. As the saga describes, "Henni pótti sér pat helzt ró, at hon sæti á hestbaki, en Pórðr leiddi undir henni aptr ok fram, ok gerði hann pat, at honum pótti stór mein á vera, en vildi við leita at hugga hana" (It was most soothing for her to sit on horseback with Pórðr leading her back and forth, and he did this, though it was very painful for him, but he wanted to comfort her) (Nordal and Jónsson 1938, p. 207). Despite putting himself in a painful and clearly humiliating situation, Pórðr takes actions to comfort his wife although her torment derives from the death of a lover whom she loved more than him. This kind of behaviour may have been expected from a husband and makes 
Brodd-Helgi's quick dismissal of his wife when she becomes ill seem even less socially acceptable. Even more than this, in contrast to Pórðr, the poor treatment that he subjects Halla to perhaps even plays a role in limiting the effectiveness of the treatment he attempts to provide her with.

Following Brodd-Helgi's death, his son Bjarni kills his uncle Geitir as revenge, though he immediately regrets the act. Geitir's son and Bjarni's cousin, Porkell, soon after returns to Iceland after a sojourn abroad, and embarks on a lacklustre vengeance attempt. At this point an important new figure is introduced into the saga named Porvarðr laknir (the healer): "Hann var vinsæll, ok var pá kallat, at hann væri beztr læknir í heraði" (He was popular, and it was thought that he was the best healer in the district) (Jóhannesson 1950, p. 53). On two occasions, Porvarðr foils Porkell Geitisson's attempts to avenge his father's death, in one instance by encountering Porkell's spy after treating a neighbour with a broken leg. Sometime afterwards, Geitir gathers a band to attack Bjarni and the saga relates that "Porkell var lítt heill jafnan ok tók opt bráđa sótt" (Porkell was always of poor health, and was often suddenly ill) (Jóhannesson 1950, p. 57). The morning of the planned attack on Bjarni, echoing the words of his aunt Halla, he tells his posse that the sally will have to be delayed due to his vanheilsa (waning health, or chronic illness) and insists that it cannot happen without him. They scold him for his cowardice and leave. The temporary onset of Porkell's illness delaying violence may be reminiscent of a motif that features men whose sudden illnesses or impairments stop them from committing actions that would simultaneously place their own lives in danger (Crocker 2019, p. 137-38, Walgenbach 2019). When Bjarni Brodd-Helgason and borkell Geitisson finally do meet for battle, the healer Porvarðr is (possibly, since the transmission of this scene is corrupted) present and seemingly on Bjarni's side, but he also displays a clear reluctance to participate in the fighting (Jóhannesson 1950, p. 59). The fight is interrupted before Porkell or Bjarni are killed, and the hapless avenger ends up with a severely wounded arm that leaves him óvigr (unable to fight). After Porvarðr treats everyone on Bjarni's side, Bjarni remarkably sends him to help nurse porkell back to health. This act facilitates a peace between the two kinsmen, who eventually become good friends, with Porkell even taking up residence with Bjarni when he grows old.

Throughout Vápnfirðinga saga, issues of health and illness both bring people together and tear them apart. Healing care is seen as a key to maintaining stable kinship, friendship, and even romantic ties. In the latter part of the saga, the healing specialist is the person who not only treats illnesses and injuries but also facilitates the rebuilding of broken relationships. Porvarðr laknir, while nominally working on Bjarni Brodd-Helgason's side, actively disrupts attempts at violence and avoids participating in such confrontations. His actions may be read as cowardice within this martial society but could also signal a sense authorial or social disapproval with Porvarðr functioning in the saga as a surrogate for the clergy's desire to uphold the 
Peace of God (Jakobsson 1998, Walter 1956, p. 44-56, Baldursdóttir 2002, Hollander 1961, p. 155). As in the example from Egils saga, Bjarni's overtures of friendship in sending Porvarðr to treat Porkell establish health as a reciprocal good that when exchanged creates or strengthens homosocial bonds between men. On the other hand, Brodd-Helgi's denial of affection and support for Halla, and her rapid replacement with the young widow Porgerðr, makes clear that poor health can quickly diminish the perceived value of a relationship. Despite the bond of love that still exists between them, which remains palpable during the final meeting between the two, it is no longer financially worthwhile for Brodd-Helgi to keep his marriage with Halla. For him, the pocket wins over the heart, which is perhaps also crudely and cruelly signified in his new wife's nickname, silfra (silver).

The way Vápnfirðinga saga organises its narrative around issues of health and illnesses, as in the previous examples, reflects the prominent social role the body had in medieval Icelandic society. It shows how healing care serves as a vital component in allowing people to establish or repair meaningful social bonds in the medieval Icelandic world, with access to professional care being an attraction for allies and followers. On the other hand, it perhaps also gives leverage to those with access to professional healers over their allies and opponents. If in modern society treatment for injuries and illnesses is primarily organised by a centralised authority, in medieval Iceland it was facilitated through the informal framework of kinship, friendship, and even romantic relationships, making these interactions all the more intimate. What is the clearest from Vápnfirðinga saga and apparent from other sagas too is that health and its management are often used as a distributed good; access to healing care can promote district power. There is of course a practical aspect at play here: The chieftain who makes certain that his men are in fighting form is likelier to succeed in the next martial encounter, as well as pose a more significant threat to his rivals. But one who has access to healing care also has the upper hand in terms of familial and friendship bonds; A hand which they can extend but also implicitly deny. In the case of Brodd-Helgi's treatment of Halla and the dissolution of their marriage due to her illness, Vápnfirðinga saga offers a stark reminder of how women were also commonly "exchanged as commodities" in medieval Iceland (Jochens 1991, p. 392). Yet, the narrative is not approving or even neutral in its stance, implying instead that the reading audience should agree with the prevailing public opinion in the community and see Brodd-Helgi's callous behaviour towards Halla for what it is.

\section{Conclusion}

Saga narratives, which feature plenty of violent conflicts, often dwell on the recourse given to people who have sustained physical trauma. Fóstbraðra saga ends with Pormóðr's final moments in a barn that has been reappropriated into a makeshift field hospital, a special space allocated for 
the treatment of those who have sustained battle injuries. Similarly, in one version of Ljósvetninga saga (referred to as the saga's C-redaction), when a man named Koðrán is wounded in battle, his brother Eyjólfr has his body moved so that he can receive treatment elsewhere. The specialist he is taken to is named Porvarðr læknir (the healer), like the healer that features in Vápnfirðinga saga and is possibly meant to be the same figure (Tirosh 2019, p. 159-62). When Porvarðr examines Koðrán he states that "ef Koðrán hefði kyrr verit, pá væri von í, en nú er engi" (If Koðrán had been left unmoved, then there would have been hope, but now there is none) (Guðmundsson and Helgason 1830, p. 88). Porvarðr here, as in Vápnfirðinga saga, accentuates the importance of access to proper care following the violent confrontations described in the sagas. For the medieval denizens of this nigh-Arctic island, access to and the distribution of healing care was on the forefront of their minds as a very real concern. Lack or mishandling of it could mean death or lasting injury. Yet, the absence of a centralised authority charged with managing such treatments meant that maintaining kinship ties and alliance building were all the more vital for one's ability to maintain their health.

Matters of health, healing, and illnesses in the medieval sagas are not, however, only concerned with the aftereffects of brutal conflicts but rather permeate all corners of the society in which the drama of these narratives plays out. Still, the ways sagas deal with these matters do not welcome close comparison with modern medical systems of thought, not only on account of cultural or social differences, but because of the nature of the texts themselves, which are not medical in their register. In some instances, such as the episode concerning Pormóðr's eye-pain and potential vision loss, health and illness may even appear to function predominantly as a kind of moral index. On the other hand, in most of the other examples discussed above, health concerns or illnesses do not seem to function as literary motifs symbolizing something else about those affected, as they commonly do in other literatures. As Bérubé (2016) notes, building on the unpublished work of Alice Sheppard, they are depicted as very tangible things with "no greater semiotic significance" (Bérubé 2016, p. 48). Yet, the context provided by the sagas still imbues these occasions with plenty of meaning, much of which is centred around whether, and if so how and by whom, treatment or healing care is provided or withheld. This stems from the fact that, in medieval saga writing, rather than deferring to a "biologically defined hegemonic body image" (Frog 2019, p. 270), ideas concerning the body, its heill (health or wholeness) and healing care are inseparably embedded within a variety of cultural traditions and social structures from which a strictly physiological understanding cannot be extracted.

In the sagas, paying close attention to the phenomenon of what is perceived as an unhealthy body stresses how thoughts, practices, behaviours, and responses to the body in medieval Iceland were shaped not by something approximating or striving towards modern medical understanding 
but rather by a complex web of cultural and social ideas and values, and primarily through one's relationships with others and their community. Of course, modern bodies are not all that different, whether characterised as healthy or unhealthy, disabled, or able, with the primary difference being the modern default to read the human body as primarily a topic for biomedical inquiry (Burroughs and Ehrenreich 1993). Yet, it is also important to recognise that health and illnesses in the sagas are not exclusively interpreted through the lens of Christianity nor do they typically function at level of literary symbolism. Likely reflecting lived experiences to some degree, they are often approached from a practical and sober perspective, which includes references to what we can identify as something like medical intervention, such as the efforts of Porvarðr in Vápnfirpinga saga. Although, as in his case, the specific details of these practices often go unremarked upon in the narratives. The different meanings attached to bodies in the sagas are frequently generated not from an interest in them as individual physiological specimens because the saga body is first and foremost a social body. As documented by the examples discussed above, it is then only natural that health, illness, and healing care in the sagas are commonly things that neither originate in nor happen to an individual in isolation but rather in and to society as a whole.

\section{References}

Baldursdóttir, S., 2002. Hugmyndaheimur Vopnfirðinga Sögu: Byggingarlag sagna frá Austfjörðum. Gripla, 13, 61-105.

Barriero, S., Forthcoming. Personal memory, family memory, collective memory? The parting gifts in Egils saga, chapter 61. Scandinavian-Canadian Studies.

Beaudry, J. S., 2016. Beyond (Models of) disability?. Journal of Medicine and Philosophy, 41 (2), 210-228. Doi: 10.1093/jmp/jhv063

Bérubé, M., 2016. The secret life of stories: From Don Quixote to Harry Potter, how understanding intellectual disability transforms the way we read. London: New York University Press.

Bragg, L., 2004. Oedipus borealis: The aberrant body in old Icelandic myth and saga. Madison, NJ: Fairleigh Dickinson University Press.

Burroughs, C. B., and Ehrenreich, J. D., 1993. Introduction: Reading the social body. In: C. B. Burroughs and J. D. Ehrenreich, eds. Reading the social body. Iowa City: University of Iowa Press, 1-14.

Collins, C., 2018. Heillög Bein, Brotin Bein: Manifestations of Disease in Medieval Iceland. In: E. Connolly and S. Kunzel, eds. New approaches to disease, disability and medicine in Medieval Europe. Oxford: Archaeopress Archaeology, 109-25.

Crocker, C., 2019. Disability and dreams in the medieval Icelandic sagas. SagaBook 43, 37-58.

Crocker, C., 2020. Narrating blindness and seeing ocularcentrism in Porsteins saga hvíta. Gripla 31, 267-292. Doi: 10.33112/gripla.31.9

Erlingsson, D., 1996. Fótaleysi göngumanns: Atlaga til ráðningar á frumpáttum táknmáls í sögu af Hrólfi Sturlaugssyni. Skírnir 170 (1), 340-356. 
Frog, J. A., 2019. Understanding embodiment through lived religion: A look at vernacular physiologies in an Old Norse Milieu. In: K. Wikström af Edholm, P. J. Rova, A. Nordberg, O. Sundqvist, and T. Zachrisson, eds. Myth, materiality, and lived religion: In Merovingian and Viking Scandinavia. Stockholm, Stockholm University Press, 269-301.

Grønlie, S., 2017. The Saint and the Saga Hero: Hagiography and early Icelandic literature. Cambridge: D.S. Brewer.

Guðmundsson, P. and Helgason, P., ed., 1830. Ljósvetnínga saga: Eptir gömlum hdr. útg. at tilhlutun hins konúngliga Norrana fornfraða félags: Sérprent úr Íslendinga sögum, 2 bindi. Copenhagen: S.L. Möller.

Hall, A., 2009. 'Pur sarripu pursa trutin': Monster-Fighting and Medicine in Early Medieval Scandinavia. Asclepio: Revista de Historia de la Medicina y de la Ciencia, 61 (1), 195-218.

Hallberg, P., 1965. (Recensioner: I. Två fakultetsoppositioner) Lars Lönnroth. Samlaren: Tidskrift för svensk litteraturhistorisk forskning 86, 157-184.

Hartnell, J., 2019. Medieval Bodies: Life, Death and Art in the Middle Ages. New York: W.W. Norton.

Heiniger, A. K., 2020. The Silenced Trauma in the Íslendingasögur. Gripla 31, 233-265. Doi: 10.33112/gripla.31.8

Hoffman, S., 2019. Place, Practice, and Pathology in Medieval Iceland: A Bioarchaeological Analysis of the Human Skeletal Remains from the Church Cemetery at Haffjarðarey (ca. 1200-1563). Thesis (PhD). SUNY: University at Buffalo.

Hollander, L. M., 1961. Saga. Untersuchungen zur nordischen Literatur und Sprachgeschichte, hrsg. Walther Baetke. Heft I: Ernst Walter, Studien zur Vápnfirðinga Saga. Halle, 1956. Heft II: Rolf Heller, Die literarische Darstellung der Frau in den Isländersagas. Halle, 1958. Heft III: Rolf Heller, Literarisches Schaffen in der Laxdoela Saga. Halle, 1960. The Germanic Review: Literature, Culture, Theory 36 (2), 154-157. Doi: 10.1080/19306962.1961.11787054

Horden, P., 2009. What's wrong with Early Medieval medicine? Social History of Medicine 24 (1), 5-25. Doi: 10.1093/shm/hkp052

Høyersten, J. G., 1998. Personlighet og avvik. En studien i islendigesagaens menneskebilde - med sarlig vekt på Njála. Bergen, NO: Universitet i Bergen.

Høyersten, J. G., 2015. Manifestations of Psychiatric Illness in Texts from the Medieval and Viking Era. Archives of Psychiatry and Psychotherapy 17 (2), 57-60. Doi: 10.12740/APP/44385

Jakobsson, Á., 2015. King Arthur and the Kennedy assassination: The allure and absence of truth in the Icelandic sagas. Scandinavian-Canadian Studies 22, 12-25.

Jakobsson, S., 1998. Friðarviðleitni kirkjunnar á 13. öld. Saga 36 (1), 7-46.

Jesch, J., and Lee, C., 2020. Healing runes. In: A. Pedersen and S. M. Sindbæk, eds. Viking encounters: Proceedings of the 18th Viking Congress. Aarhus, DK: University Press, 386-398.

Jochens, J., 1991. The illicit love visit: An archaeology of Old Norse Sexuality. Journal of the History of Sexuality 3 (1), 357-392.

Jóhannesson, J., 1950. Vápnfirðinga saga. In: J. Jóhannesson, ed. Austfirðinga sögur: Íslenzk fornrit 11. Reykjavík: Hið íslenzka fornritafélag.

Jónsson, E., and Jónsson, F., ed., 1892-96. Hauksbók: Udgiven efter de Arnamagnaanske håndskrifter no. 371, 544 og $675,4^{\circ}$ samt forskellige papirshåndskrifter. Copenhagen: Det Kongelige Nordiske Oldskrift-selskab. 
Kanerva, K., 2013. "Eigi er sá heill, er í augun verkir" Eye Pain as a Literary Motif in Thirteenth and Fourteenth-Century Íslendingasögur. ARV-Nordic Yearbook of Folklore 69, 7-35.

Kanerva, K., 2014. Disturbances of the mind and body: The effects of the living dead in medieval Iceland. In: S. Katajala-Peltomaa and S. Niiranan, eds. Mental (dis)order in the Later Middle ages. Leiden, NL: Brill, 219-242.

Kanerva, K., 2015. Porous bodies, porous minds: Emotions and the supernatural in the Íslendingasögur (ca. 1200-1400). Thesis (PhD). University of Turku.

Karras, R. M., 2003. Marriage and the creation of Kin in the sagas. Scandinavian Studies, 74 (4), 473-490.

Kristjánsson, J., 1972. Um fóstbræðrasögu. Reykjavík: Stofnun Árna Magnússonar.

Künzler, S., 2016. Flesh and word: Reading bodies in Old Norse-Icelandic and early Irish literature. Berlin: Walter de Gruyter.

Larsen, E., ed., 1931. An old icelandic medical miscellany. Oslo: Den Norske Videnskaps-Akademi i Oslo.

Lönnroth, L., 1965. Kroppen som själens spegel - ett motiv i de isländska sagorna. Uppsala, SE: Lychnos Lärdomshistoriska samfundets årsbok.

McDougall, I., 1992. The third instrument of medicine: Some accounts of surgery in medieval Iceland. In: S. Campbell, B. Hall, and D. Klausner, eds. Health, disease and healing in medieval culture. Toronto: Centre for Medieval Studies, University of Toronto, 57-83.

Merkelbach, R., 2019. Monsters in society: Alterity, transgression, and the use of the past medieval Iceland. Berlin: De Gruyter.

Nordal, S., ed., 1933. Egils saga Skalla-Grímssonar: Íslenzk fornrit 2. Reykjavík: Hið íslenzka fornritafélag.

Nordal, S., and Jónsson, G., 1938. Bjarnar saga Hítdælakappa. In: S. Nordal and G. Jónsson, eds. Borgfirðinga sögur: Íslenzk fornrit 3. Reykjavík: Hið íslenzka Fornritafélag.

Pálsson, V., 2015. Language of power: Feasting and gift-giving in medieval Iceland and Its sagas (Islandica 60). Ithaca, NY: Cornell University Press.

Poilvez, M. A., Troll Did It? Trauma as a Paranormal State in the Íslendingasögur. In: Á. Jakobsson and M. Mayburd, eds. Paranormal encounters in Iceland 1150-1400. Berlin: de Gruyter 2020, 71-88.

Reichborn-Kjennerud, I., 1936. Vår eldste medisin til middelalderens slutt. In: I. Reichborn-Kjennerud, F. Grøn, and I. Kobro, eds. Medisinens historie i Norge. Oslo: Grøndahl, 1-97.

Schulman, J. K., 1997. Make me a match: Motifs of betrothal in the sagas of Icelanders. Scandinavian Studies, 69 (3), 296-321.

Sexton, J. P., 2010. Difference and disability: On the logic of naming in the Icelandic sagas. In: J. R. Eyler, ed. Disability in the middle ages. Reconsiderations and reverberations. Farnham, UK: Ashgate, 149-163.

Sexton, J. P., 2020. Atypical bodies: Seeking after meaning in physical difference. In: J. Hsy, T. V. Pearman, and J. R. Eyler, eds. A cultural history of disability in the Middle ages. London: Bloomsbury, 19-34.

Shakespeare, T., 2014. Disability rights and wrongs revisited. London and New York: Routledge.

Simek, R., 2019. Tangible religion: Amulets, illnesses, and the demonic seven sisters. In: K. Wikström af Edholm, P. J. Rova, A. Nordberg, O. Sundqvist, and T. Zachrisson, eds. Myth, Materiality, and lived religion: In Merovingian and Viking Scandinavia. Stockholm: Stockholm University Press, 375-395. 
Sigurðsson, J. V., 2017. Viking friendship: The social bond in Iceland and Norway, C. 900-1300. Ithaca, NY: Cornell University Press.

Tirosh, Y., 2014. The fabulous saga of Guðmundr inn riki: Representation of sexuality in Ljósvetninga saga. Thesis (MA). University of Iceland.

Tirosh, Y., 2019. On the receiving end: The role of scholarship, memory, and genre in constructing Ljósvetninga saga. Thesis (PhD). University of Iceland.

Tulinius, T. H., 2018a. I: 17 Trauma studies. In: J. Glauser, P. Hermann and S. A. Mitchell, eds. Handbook of pre-modern Nordic memory studies: Interdisciplinary approaches. Berlin: de Gruyter, 250-255.

Tulinius, T. H., 2018b. II: 15 Trauma. In: J. Glauser, P. Hermann and S. A. Mitchell, eds. Handbook of pre-modern Nordic memory studies: Interdisciplinary approaches. Berlin: de Gruyter, 495-501.

Walgenbach, E., 2019. Inciting Miracle in Njáls saga: Ámundi hinn blindi's Gift of Sight in Context. Saga-Book 43, 125-136.

Walter, E., 1956. Studien zur Vápnfirðinga Saga. Untersuchungen zur nordischen Literatur- und Sprachgeschichte 1. Halle (Saale), DE: VEB Max Niemeyer Verlag.

Whaley, D. C., and Eliot, D., 1994. A medieval casebook: Hand cures documented in the Icelandic sagas of bishops. Journal of Hand Surgery (British and European Volume) 19 (5), 667-671. Doi: 10.1016/02667681(94)90141-4

porgeirsdóttir, B., 2015. Elskhuginn Egill Skallagrímsson. Skírnir 2, 360-397.

Porgeirsdóttir, B., 2018. Humoral theory in the medieval north: An Old Norse Translation of Epistula Vindiciani in Hauksbók. Gripla 29, 35-66.

Pórólfsson, B. K., and Jónsson, G., 1943. Fóstbrœðra saga. In: B. K. Pórólfsson and G. Jónsson, eds. Vestfirðinga sogur: Íslenzk fornit 6. Reykjavík: Hið íslenzka fornritafélag. 


\title{
8 Physical Impairment and the Spatial Dimensions of Everyday Life in Rural Households in Pre-industrial Iceland
}

\author{
Ólafur Rastrick
}

\section{Introduction}

A number of studies exploring disability and housing address the question of how design and layout of dwelling and home environment affects the quality of life of individuals who are physically impaired (Imrie 2004). Mostly confined to contemporary society and modern spaces, these studies adhere for instance to questions of access, segregation, activity, and participation in and out of the home of people whose mobility is restricted (Imrie and Edwards 2007, Titchkosky 2011, Wiesel and van Holstein 2020). Transposing such concerns onto traditional rural households in Iceland, the chapter seeks to illustrate and analyse the "social space of disability" (Gleeson 1999, 2001) within the turf-house-based community, exploring the predicaments of people with physical impairments as regards the domestic space of the turf-house and relating it to broader historical-geographical character of 19 th and early 20 th century Iceland.

The discussion rests on the premises that the pre-industrial Icelandic economy was almost entirely household-based till the late 1800s and in some rural areas well into the 20th century, with the rural household as the unit of production (Gunnarsson 1987, Magnússon 1985). A large part of everyday existence of the community in general, including work and education, thus, took place within the confined space of the bar (turf-house cluster). As disability writer Vic Finkelstein (1981) and others have noted from cases elsewhere, the predicaments of people with physical impairments in such pre-industrial societies differed greatly in this context from what emerged in the urbanised modernity that followed the Industrial Revolution. This line of argument has led disability theorist Tom Shakespeare (2018) to conclude that "from the disability perspective, the way of life in pre-industrial, pre-capitalist times might have been more inclusive, for those that survived their illness or injury" (Shakespeare, p. 27). On this note the chapter seeks to explore the relationship between disability and space within the turf-house setting, illustrating ways in which architecture and the social space of the turf-house interacted with everyday life of physically impaired individuals.

DOI: $10.4324 / 9781003180180-9$ 
Special attention will be given to the cases of two individuals with physical impairment: 1) the pauper Kristján Benediktsson and 2) the farmer Árni Jakobsson. Kristján's legs and fingers had been amputated after severe frostbite in his early 20 s and he remained in a state of pauperism throughout his life. Árni on the other hand took up farming along with his wife in the remote highlands of northern Iceland in early 20th century, after contracting polio at the age of 23 which left him paralysed from the waist down. The latter's unique memoirs published posthumously (Jakobsson 1963) offer vivid insight into the relationship between an impaired body and the domestic space of the turf-house. The chapter argues that in important ways the social structure of the turf-house-based community, and, especially, the spatial design and the vernacular architecture of the turf-house, created a very different dynamic between space and "different" bodies than the modernist spaces of the industrialised urban spaces did later on. It is indeed suggested that the social and domestic space of the turf-house-based community did in a sense have a less disabling effect on individuals with physical impairments than the spatial design of the society that supplanted it.

\section{The centrality of the rural household in pre-industrial Iceland}

The structure of Icelandic society, both socially and economically, was more or less untouched by the effects of the industrial revolution until the 20th century. Until the late 1800 s almost the entire Icelandic population (of 70,000 in 1875) relied on subsistence farming for survival in the harsh climate of the North Atlantic, living in sparsely distributed hamlets or cottages, mostly in the coastal regions but also inland in some areas. Due to legal restrictions, towns did not emerge until the late 19th century with the population of the largest, Reykjavik, only reaching 6.000 at the turn of the 20th century (Karlsson 2000). One of the main legal obstacles to urban development lies in the system of vistarband which required everybody that did not own or lease a farmstead to become a labourer/domestic servant at a farm (Vilhelmsson 2017). Those who could not provide for themselves for some reason, such as impairment, often ended up as paupers (niðursetningur), assigned for payment to a household by the local government. Poorhouses/hospitals did exist in the country till mid-19th century but were then abandoned. However, such institutions would at any time only have housed between 16-20 individuals in total. The historian Gísli Ágúst Gunnlaugsson (1983) estimated for the 18 th century that paupers were on average around $10 \%$ of the population, or between 4-5.000. Modern medical institutions designed to support individuals with impairments did not exist to any extent until the turn of the 20th century with the founding of establishments, such as the leprosarium at Laugarnes in 1898 and the mental health care hospital at Kleppur in 1907 (Guðjónsson 2013a, Halldórsdóttir 2020). This meant that people 
with mental and physical impairments who had access to stable residence were to a lesser extent spatially segregated from others and lived nonsegregated within households, even though multiple exceptions are known, where, especially, people with psychiatric issues were locked up in shacks and outhouses (Guðjónsson 2013a, 2013b).

A typical rural household in the 19th century would consist of a farmer and his wife, children, sometimes aged parents, domestic servants, and often paupers. Most households were economically dependent on domestic production, relying on work carried out within the domestic space, especially, processing wool (Karlsson 2000, Gunnlaugsson 1988). This does not mean that all work was performed in the cottages - a significant part of the labour, such as tending animals and harvesting (hay) was usually undertaken in the proximity of the farmhouse - while other economically significant activity required more mobility. Such activities included looking after or heading livestock, overseeing shielings (sel), collecting Iceland moss (fjallagrös), and travelling seasonally to distant parts of the country for fishing (Jónasson 2010).

The economic position of people with physical impairments within the rural household is in many ways comparable to their place in other preindustrial societies. Addressing the transformation to the work-related predicament of people with physical impairments prior to the Industrial Revolution in England, Vic Finkelstein, already in 1981, drew attention to the role of "cripples" in the pre-industrial household-based economy.

Apart from performing domestic duties for their families, such as cooking, making clothes, and looking after the young children, when possible, cripples [sic.] unable to perform agricultural work could have supplemented the family income by spinning and weaving. Small and portable, the early machines could have been easily adapted to suit individual physiques. The work was carried out in their homes and cripples had no need to seek employment beyond the family (Finkelstein 1981, no pagination).

This was to change, Finkelstein (1981) asserts, with the emergence of capitalism and industrial urbanism. In 19th century England traditional cottage industry was no longer competitive and the most vulnerable, people with impairments were forced to turn to begging and church protection in poorhouses. The market favoured the industrialised factories which produced woven material more efficiently (Finkelstein, 1981, Gleeson 1999, Oliver 1990, Oliver and Barnes 2012). Conversely, in agrarian societies, as Shakespeare (2018) illustrates, "whether in medieval Europe or in rural parts of Africa and Asia today" (p. 28-29) - or indeed 19th and early 20th century rural Iceland - "disabled people experienced a similar level of poverty or hardship as everyone else (p. 29)." In a society where the household is the unit of production everyone belonging to that household could potentially 
contribute for its benefit. Drawing on his research in Africa, Shakespeare (2018) concludes:

If everyone is working at subsistence levels, and households support all its members, then disabled people may not be as disadvantaged as we might imagine. Really determined individuals can sometimes manage to do very well (p. 28).

The central section of 19th century turf-house was the baðstofa, the communal room of each household which functioned simultaneously as bedroom, dining room, and workspace for the cottage industry and in most cases the space for receiving visitors. Indeed, much of the everyday was confined to the space of baðstofa, especially, during winter from October until April. As the historian Gunnar Karlsson (2000) notes, "it was customary for the whole household to live practically all their indoor life in the baðstofa, often with two sharing each bed" (p. 250). This gave little leeway for privacy in the sense that is associated with the modern notion of home as sanctuary (Hálfdanarson 2008). The baðstofa functioned also as the main space for religious practice, schooling, and leisure, most notably in the form of the evening veillée ( $k v o ̈ l d v a k a)$, consisting of both religious and secular activities. Though some attended church regularly or occasionally, daily religious observation was a central part of the kvöldvaka where a designated individual would read out loud for the benefit of the entire household. In addition to religious texts, the sagas or other vernacular prose or poetry would be read aloud. The kvöldvaka might also include the singing of psalms and performance of various kinds, such as storytelling and reciting or chanting of the local form of ballads, rímur (Gíslason 1977, Jónasson 2010). Primary schools were virtually unheard of in rural areas before the 20th century so both religious education and instruction in reading (and eventually writing and arithmetic) took place at home and was the responsibility of the household under the supervision of the local priest (Guttormsson 2008). The teaching would have usually taken place in the baðstofa.

Like in matters of economic production, all members of the household, including those with various forms of impairment, would have taken part or at least been present during cultural consumption in the turf-house. Even though examples of segregation of individuals with mental disorders exist (Guðjónsson 2013a), most individuals with impairments would have shared the space of the baðstofa with other people of the household. This would also be the case with visitors, including those who lived outside the vistarband system that required everyone that did not own or lease a property to be employed on a farm.

Vagrancy was commonly seen as social menace by the ruling elite and many independent farmers. However, as ethnologist Jón Jónsson (2018) has demonstrated, vagrancy was interwoven in the socio-economic structure of the peasant society and vagrants often provided services that were 
sought after. To survive, these individuals were to some extent receivers of alms, travelling between farmsteads seeking food and lodgings, but also performing various services, such as undertaking specific chores or offering entertainment in form of stories, news, gossip, or other types of performance during the kvöldvaka. As a rule, the vagrants joined the rest of the household in the baðstofa during their stay, even though they sometimes outstayed their welcome at the farm.

A number of the vagrants Jónsson (2018) explores can be said to have had some form of physical or mental impairment. Thus, even though the social space of many individuals with physical or sensory impairments may have been confined to the constellation of the farmhouse (bær) others travelled (for longer or shorter periods) from one household to the next, seeking alms or rendering services of some sort.

\section{Disability, domestic space, and the vernacular architecture of the turf-house}

The turf-houses enjoy a paradoxical reputation in Icelandic cultural history. Through a process of rapid modernisation, turf-houses went from being the prevailing form of residential housing in the early 1900s, especially, in rural areas, to having virtually disappeared by mid-century (Jónsson and Magnússon 1997). The emerging medical profession at the turn of the century proclaimed these buildings unsanitary dwellings and the proponents of cultural modernisation, echoing foreign perceptions, deemed them shamefully primitive, not appropriate as the residences for a proud civilised nation (Hafsteinsson 2019, Hafsteinsson and Jóhannesdóttir 2015, Rastrick 2013). Conversely, the turf-houses also had a place in the romanticised vocabulary of the patriots of the nationalist movement of the late 19th and early 20th century who saw them as embodying the symbiotic relation between nation and land (Rastrick 2012). Furthermore, in recent years, the few remaining (showcase) turf-buildings have gained renewed interest as endangered cultural heritage and as a more sustainable mode of housing in times of climate awareness (Sigurðardóttir 2020, Kreps 2019). Whether turf-houses are a testimony of the poverty stricken past (Magnússon 2019) or a clever synthesis of centuries of human habitation in the harsh climate of the North and a guiding light for a sustainable future (Lárusson 2014), is a matter of debate (Hafsteinsson 2010).

Without doubt the turf-houses were often unpleasant dwellings. While ample descriptions of clean and warm turf-houses exist, others portray them as miserably dark, filthy, and damp (Emilsson 1976). "Take care when you get inside," the French scientist Paul Gaimard wrote in his diary reciting the advice of a local official upon entering the cottage Krossanesbær in Iceland's North, "you might inadvertently sit on a leper." After describing the harrowing circumstances of the young man found in the turfhouse, Gaimard concludes: "Our visit to this croft was testimony of the great human misery that is apparent in Iceland" (cited in Snævarr 2019). 
For persons with diseases or otherwise impaired, the quality of housing affected the quality of life, even more so than it did for others. However, other aspects of everyday life in the turf-house give pause for thought about the spatial predicaments the vernacular architecture of the turf-house fostered for people with physical impairments in comparison with the type of dwellings that replaced them.

The modern idea of the home is often seen in idealistic terms as a safe haven or retreat from the toils of everyday life, a place of security, privacy, and independence. This perception has been challenged from a variety of perspectives, for instance noting that the home is for some a place of violence (Warrington 2001) and loneliness and social disengagement (Macdonald et al. 2018). Writing on the domestic experience of people with impairment in modern society, geographer, and disability scholar Rob Imrie $(2003,2004)$ highlights the role of spatial design of homes in having disabling effects on persons with physical impairment. This, Imrie (2004) maintains, is in part "because design conceptions, in relation to floor plans and allocation of functions to specific spaces, do not conceive of impairment, disease and illness as part of domestic habitation or being" (p. 746). Thus, it can be said that design and layout of the home environment directly affects the quality of life of individuals that are physically impaired. Imrie (2004), does, however, not endorse the view he associates with the social model of disability which he claims, "tends to conceive of individuals as 'victims' of circumstances beyond their control, in which they are oppressed by social and environmental factors" (p. 756). Conversely, he argues that people with impairments are "not passive victims of insensitive design" (Imrie 2004, p. 756) but can and do, as his study illustrates, embody "capacity to generate useable spaces out of the social and physical impediments that are placed in their way" (Imrie 2044, p. 756).

Returning on that note to the turf-house, it has been described as an organic structure in a perpetual state of construction. For adequate maintenance of the cluster of houses that constitute a bær the farmer/occupant would as a rule have to undertake repairs on the structure every year rebuilding or renewing a wall, roof, or whole sections of the building cluster. Working with organic materials found in proximity of the farm, such as stones and turf (and timber, especially, where driftwood was readily accessible), the architecture of the buildings was subject to building materials at hand (Sigurðardóttir 2008, 2012, Stefánsson 2013, Lárusson 2014, van Hoof and van Dijken 2008). Furthermore, the structure of the buildings would in some instances vary from time to time, depending upon economic resources and needs of the households. For instance, during dire times the buildings tended to become more compact. While, as with other types of vernacular architecture, the building of a turf-house was based on knowledge and experience, no bær was identical. Different from the standardised modernist building (Imrie 2000) the ongoing rebuilding of the turf-house opened for continual architectural adaption to suit the needs of the inhabitants within the confines of resources and know how. 
One of the outcomes of drawing attention to the interlinkage between design and wellbeing is the introduction of the notion of universal design (UD). The adoption of this approach in policy and design can be seen as a consequence of the paradigmatic shift in focus associated with the social model of disability, referred to above. Instead of seeing the individual as disabled due to medical defects or dysfunction, society and its structure are identified as having disabling effects on the individual that diminishes accessibility, the quality of life and human rights of individuals with impairments. Proponents of universal design have sought to counter the tendency of, for example, modernist architecture to design for the normalised body and thus disregarding human diversity. Instead, proponents of UD seek ways for design "to be usable by all people, to the greatest extent possible, without the need for adaptation or specialized design" [CRPD 2006: Art. 2 (5)]. In terms of architectural design, the call for universal design targets consequences of modern production techniques that favour standardisation of furniture, height of cabinets, etc. This is also directed at things like stairs, that disregard that in many cases reduce the mobility of people with physical impairments.

Universal design targets certain effects of modernity, such as architectural design that has disabling effects on the individual with impairments, reducing mobility, hindering execution of various tasks, and curbing social participation, among others. The past offers of course ample examples of such disabling effects of the environment, such as the lack of support equipment. However, pre-industrial architecture was much less prone to standardisation than modern housing. This applies, especially, to premodern vernacular architecture where standardisation was by definition non-existent. The notion of universal design can hardly be seen as applicable to analysing pre-modern contexts. However, it draws attention to disabling character embedded in modern architecture and urban design which is also reflected in elements of industrial and post-industrial society, such as spatial division of home and workplace. Thus, the notion is useful in the historical context as a critical stance towards the idea of homogenous progress and opens up space to compare predicaments of people with impairments in pre-modern societies, such as the Icelandic turf-housebased community, to the hindrances met by such individuals in urbanised modernity. To be able to make this comparison, or to be able to assess how changing socio-spatial organisation interacted with the lived experience of persons with physical impairment (Gleeson 1999), it is necessary to look more closely at the nature of the turf-house.

\section{Physical impairment and everyday life in the turf-house}

The following discussion refers to persons with physical impairments who lived and worked in turf-houses. The objective is to give insight into how their everyday lives were mediated by the physical and social space of the 
vernacular architecture and its socio-cultural context. It should be stressed that there are many types of physical impairments that affected people in different ways and that the predicaments of individuals in the turf-house community were diverse. The cases referred to should be seen as such and may or may not be representative of a larger population. The pretext to the discussion rests on the above comparison between the socio-cultural context of traditional rural Iceland and the modern urbanised world, the latter being premised to a much larger extent on daily mobility of individuals and standardisation of the built environment. Speculating on notions of activity as "execution of a task or action by an individual" and participation as "involvement in life situations" (WHO 2001, p. 10, Chang and Coster 2014) it is suggested that both social structure and vernacular architecture of pre-modern Iceland facilitated activity and participation that was met with hindrance at the onset of urban modernity.

Commenting on the scarcity references to impairment in historical documents, Gleeson (1999, p. 97-98) notes that bodily impairment was "doubtless an accepted, prosaic element of peasant life" and thus went generally unnoticed. What he refers to as the "ubiquity of impairment" can thus explain its "relative invisibility" in historical records (Le Goff 1988, Metzler 2013). Reflecting that perspective on to Icelandic peasant society there seems to be no reason to suspect that this was not the case there. Both in public documentation, such as census material, and private sources, bodily impairment was in all probability underrepresented because it was relatively common. However, some relatively reliable first-hand descriptions exit, reflecting the predicaments of the bodily impaired in preindustrial rural Iceland.

\section{The case of Kristján "The Legless"}

One common form of injury that caused impairment in Icelandic peasant society of previous centuries was frostbite. Harsh and unstable climate during winter left many seafarers and travellers in the sparsely populated country without fingers and toes. Sometimes arms and legs would need to be amputated. Quite a few would be labelled with their impairment, going by names, such as Kristján fótalausi or Kristján the legless (Vilhjálmsson 1941). Fótalausi seems to have been a popular byname or tag for people whose legs had been amputated. Guðrún Bjarnadóttir (1770-1859), known as Gunna fótalausa, suffered frostbite at the age of 15 and both her feet were amputated at the level of the ankle. As a poverty-stricken orphan she rose to become a prosperous farmer, landowner, and boat-builder (Jónsson 1914, p. 181-182). Another was Ásmundur Ásmundsson (1845-1924), a.k.a. Ásmundur fótalausi, who due to frostbite lost also both legs at the ankle, as well as his left arm by mid forearm when he was in his mid-20's. He later emigrated to Canada to become, for a while, a quite prosperous farmer (Porbergsson 1917, Anon 1924). Jón S. Sigurðsson (1856-1931), or Jón fótalausi, lost both 
legs just below the knee after being shipwrecked in 1880 but continued as a fisherman for decades after. A fellow fisherman claimed that "few were his equals when it came to drive and hardiness at sea" (Víglundsson, 1969, p. 62). The same person also describes his work method:

To my knowledge he preferred rowing vessels. In these there was a rib (röng) mid-ship. In front of the rib placed a bar right across the width of the boat which he would push his knees against when rowing. He would crawl on four feet from prow to stern and was quick about it (Víglundsson 1969, p. 61-62).

Several other examples of people that carried the same labelling of fótalausi due to their impairment can be found through-out the 19th century. The testimonies sometimes bear witness to curious resilience and resourcefulness in a society that offered no public support or readymade support equipment.

The case of Kristján Benediktsson (1803-1891), who went by the name Kristján fótalausi, is compelling. His story was recorded by poet and scholar Konráð Vilhjámsson, published in 1941. Vilhjámsson-based his account on the testimonies of people who knew Kristján from mid-century onwards. Kristján suffered severe frostbite in 1826 after getting lost in a snowstorm. The result was that both legs were amputated beneath the knee (with a farm saw usually used for cutting timber), as well as his fingers above the knuckles closest to the hand (proximal phalange) - with a chisel, leaving only small stubs. Frostbite had also scathed his nose which was partly removed "so you could from then look directly into his nostrils" (Vilhjálmsson 1941, p. 26). Surviving this, he lived well into his 80 s, residing as pauper at different households in upper Bárðardalur in the district of Ljósavatn in Iceland's north.

Kristján is described as a robust child, but unruly and mischievous, later medical knowledge might have diagnosed him as having a disorder of some sort. This personal trait seems to have followed him through adulthood. At least he seems not always to have been a welcome addition to the households to which he was assigned as pauper, having resided at a number of farmsteads through the years. Conversely, in spite of being described as fierce looking and commanding a ferocious voice, he was said to have been particularly good with children.

From the time of his impairment, Kristján was unable to walk but crawled wherever he went with knees and stubs wrapped in calfskin for protection. Apart from attending to children, he is said to have had various chores which were beneficiary for the household. His job was for instance to card horsehair and making ropes, his finger-stubs reportedly sensitive enough to pick up a needle from the floor. Another job was to administer hand operated grinding mills. He also worked outside, is claimed to have been a specialist in handling "great big rocks that he would roll for a distance and lift to his chest and pile up, as he was extremely strong and hardy, all things considered" (p. 27). 
Due to what is described as his "impetuosity" some households seem to have found it necessary to exclude him at times form the communal baðstofa, "in some places he was kept on a stall in the cowhouse, particularly during winter" (p. 29). This segregation is explained with reference to his mental state while it simultaneously suggests that this was an emergency measure. Thus, in terms of activity he seems to have had valued roles within the household as he would fulfil work tasks that were beneficiary for the sustenance of the farm, while his participation in the everyday life of the farmstead seems to have been restricted at times, but not always as positive reference to his engagement with children bears witness. In light of his contribution to the household, it would have been seen as both normal and desirable for him to share the common space of the farmhouse and thus participate in the economic and cultural activities of that took place in the collective space of the baðstofa.

\section{The case of Árni Jakobsson of Víðasel}

Population growth in the early 19th century led to increased settlement in the highlands of Iceland's north-east, a vast area that had only sporadically been populated through the centuries. The heyday of this settlement was between 1820-1860 and some farms survived into the 20th century. While these farmsteads consisted of extensive grasslands suitable for sheep grazing, they proved extremely meagre in terms of revenue due to the harsh climate conditions in the highlands, with significantly shorter summers and severe winters.

The following discussion draws on the published memoirs of Árni Jakobsson (1963), born 1891 in the district of Mývatn. In the spring of 1915 Árni Jakobsson and his wife Sigríður Kristín Sigurgeirsdóttir acquired the cottage of Víðasel in the highlands west of lake Mývatn. They had gotten married the previous summer with the intention of becoming farmers. Their luck turned for the worse in late 1914 when Árni contracted polio that left him paralysed from the waist down. This did, however, not dissuade the couple form acting on their dreams, seeking independence and establishing their own household. In many ways the housing predicaments that Árni describes in the following are of the kind that were common in the 19th century. In the period that he describes from 1914-1926 the social structure that fostered this type of habitation is, however, about to cave in, giving way to new building materials and urbanised modernity.

Árni's memoirs offer a detailed description of the state and layout of the cottage. He describes the different spaces of the bær and especially the main living quarters, the baðstofa. As such his recollections testify to how his impaired body was met by the cottage architecture. Arriving with their belongings at Víðasel in 1915 the couple found the buildings in dismal condition and need of repair. Árni recalls his initial impression after the trying journey, seeing the farmhouse for the first time, he writes, "I am filled with 
dread" (p. 74). As he was physically quite weak during their first summer at Viðasel the rebuilding of the baðstofa was mostly left to his father, who accompanied the couple, and to Sigríður. While the rebuilding took place, Árni spent most of his time in a small shed intended as shelter for sheep adjacent to the cottage. His description gives an idea of his physical state:

I'm mostly alone in the shed while the rebuilding takes place. Nothing much to do and the solitude is dreary. When the weather is good, I try to crawl outside. Here, there are no high thresholds or other obstacles and I have become strong enough to crawl a bit without assistance. If I am helped up, I can even stand for a moment by holding myself upright with my hands (p. 78).

To his dismay, Árni's physical state makes it impossible for him to oversee or take part in the renovations as was his intention and would have been expected of him as the farmer of Víðasel, had he not been hindered by impairment. Though obviously anguished by his predicaments he notes on the positive side the lack of hurdles in the shed which makes it easier (than if he resided in the farm) to move around and go outside. Here, it can thus be said that the lack of architecture reduced his immobility.

A couple of years later in the summer of 1917, renovations are again underway with the rebuilding of the open hearth kitchen, pantry, and cowshed. He has now gained strength in his hands and participates fully in the project.

My father built the walls of these buildings mostly on his own. The foundations were of stone and the rest of the walls turf. I cut most of the turf-blocks [for the wall], as well as the turf for the roof. I had gained so much strength in my hands that I could accomplish this task, but I had to either kneel down or sit flat on the ground, so my posture was rather demanding (p. 103).

Here, Árni has gained his position as farmer. He is an active participant in renovating/rebuilding his own farm. In the context of the Icelandic peasant society his determination is an indication of his activity and participation. This is what accomplished farmers did if they intended to pursue a living on the farm. To paraphrase Imrie (2004), challenging the impediments placed in his way, the resourceful farmer set about reproducing appropriate useable spaces at the farm.

The accompanying photograph (see Fig. 8.1) from the early 1910s shows previous residents in front of the entrance of the highland cottage. From this photograph, Árni's detailed description of the interior from his memoirs (Jakobsson 1963, p. 74-79) and aerial photographs of the ruins (Ingason 2020) an outline can be drawn up of the living area (baðstofa) and sheep house outlining the layout of the building seen on the photograph. In minute 


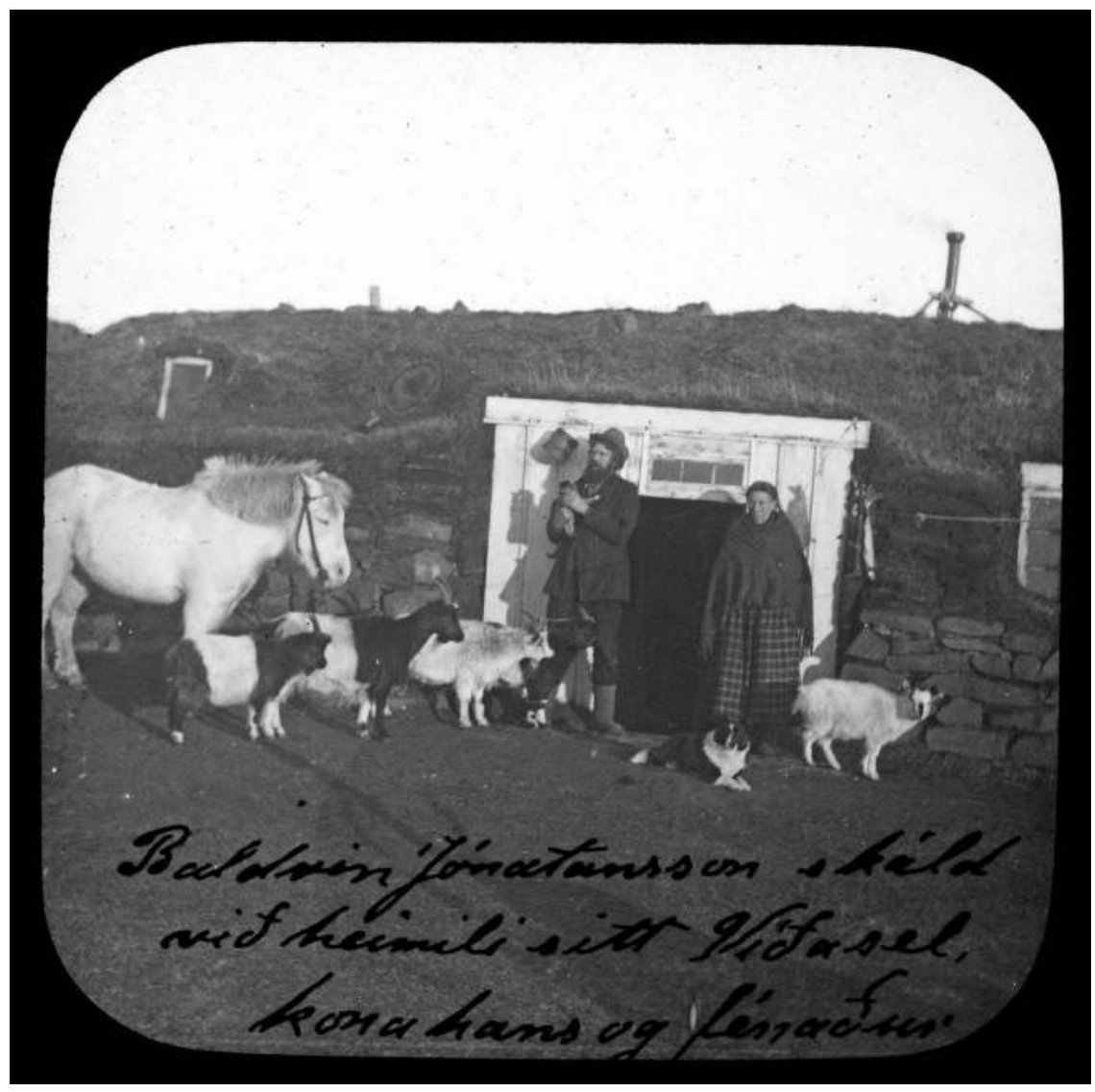

Figure 8.1 Víðasel cottage.

detail Árni describes the entrance in the middle of the northern side, with timber panel on either side and a tree pane window above the door. When inside a corridor divided the building, about two meters wide. The sheep house was on the left (northern side) and the baðstofa to the right. You entered the baðstofa through a door while the sheep house, holding around 20 sheep, was separated from the corridor with railings. Beyond the corridor, east of this main building, were the kitchen, pantry (both rebuilt in 1917 as described above), barn and the shed where Árni spent his days during the initial renovation (Jakobsson 1963, p. 74-76).

The baðstofa was according to Árni "five [Danish] ells on each side," which means that the living area of the cottage was in total no more than ten square meters (Jakobsson 1963, p. 75). In this confined space the inhabitants would spend sometimes days on end, especially during winter, in the company of each other. According to the national census of 1920 
(NAIS 1920) in addition to Árni and Sigríður, his parents were living in the cottage, as well as two domestic servants, a boy of 15 years and a 43-yearold female. Within the baðstofa was a stove, bedsteads, and a small table. Árni describes the furniture in the living area as consisting of primitive bedsteads along the southern wall made of mud, brushwood and canvas and separated by a gable. A stove was in the north-east corner and "a semi-circular table attached to the wall under the window ... where two could eat at once if the food was served in the traditional way where edibles were served on a single plate and spoon food in bowls." One window "with six small panes" was on the baðstofa, above the table and facing west (Jakobsson, 1963, p. 75). The edge of the window can be seen on the lefthand side of the photograph.

As noted above the baðstofa was the space the residents would spend most of indoor life, which meant a substantial part of their time, at least during the long winter months from October till April. The fact that so much of the activities of the household took place within this confined space can thus be seen to have facilitated Árni's inclusion and social participation as head of household. Rather than seeing Árni as a victim to substandard housing, the primitive accommodation can be interpreted as opening up possibilities of activity and participation for a person with reduced mobility.

Like in other pre-industrial societies the question of moving from one place to another, such as between home and workplace, was less an issue than it would be in the industrialised urban spaces. In Víðasel the cottage industry was updated in 1919 when Árni bought a knitting machine with financial assistance from friends and neighbours.

The knitting machine served me well, I soon got all sorts of orders from persons in the districts of Reykjadalur and Mývatn. After I came into the possession of the machine, I sometimes had some money to spend, and it proved convenient for paying off debts. People from Mývatn sometimes paid with eggs and trout which was a windfall for us. And last but not least my circumstances took a turn for the better when I got the machine, as the boredom of idleness no longer haunted me (Jakobsson 1963, p. 108).

Árni's impairment did not hinder him from contributing to the economic sustainability of the household, taking part in the cottage industry. He seems, however, to have only undertaken chores that would have been considered manly. He cuts turf and operates the knitting machine, which is comparable with ministering the loom, which traditionally was a man's job within the cottage industry. Even plagued by boredom he does not venture into the female work domain, even though his wife would overtake some of the outdoor work that was traditionally the male-partner's role. Árni and Sigríður were the last occupants of Víðasel and left the cottage in the 
autumn of 1926 to settle in the emerging town of Húsavík. They were of the last generation that lived in a turf-house.

\section{Conclusion}

The spatial nature of the 19th century turf-house, where the whole household would "live practically all their indoor life in the baðstofa" (Karlsson 2000 , p. 250), raises important considerations about disability and participation. Harsh and unstable climate conditions and available building resources dictated the design, creating these condense multi-purpose places of gathering and interaction. As with standardised modernist architecture, the vernacular design of the turf-houses shaped the material context of the social space. For social inclusion access to these social spaces of the cottages was imperative. And access, as disability scholar Tanya Titchkosky (2011, p. 4) argues, "is tied to the social organization of participation, even to belonging."

The social structure, though in many ways notoriously inhumane when it came to the dispossessed, can also be seen to have influenced social inclusion actualised in the baðstofa. This adheres to both adult paupers and vagrants who in many cases were persons with impairment of some sort. As a form of social security, and ensuring farmers cheap labour, paupers were assigned to farms and as a rule shared the space of the baðstofa with other members of the households. When vagrants turned up at farmsteads, they also were generally put up in the same communal space as anyone else (Jónsson 2018) and in that way social legislation of the peasant society contributed to this type of spatial inclusion.

Though the case of Kristján "the legless" Benediktsson shows that not everyone was always welcomed in the baðstofa, it was more often than not an inclusive social space. The household being the economic unit, people with impairments were required to contribute with their labour in a way that was beneficiary for the sustainability of the farm. If not too unruly from the perspective of the master of the house, it would have been seen as beneficial for the household to include Kristján in the activities in the baðstofa, where an eye could be kept on him to ensure his diligence when it came to completing his chores. By sharing the social space days on end the inclusion also extended to cultural activities and consumption; storytelling, gossiping, frolicking, chanting of rímur, recitals from secular and religious texts, receiving visitors and so forth. In this regard access to the social space involved inclusion and participation.

Árni Jakobsson's descriptions of the interior at Víðasel-cottage gives an example of how the condense space of the baðstofa and other buildings in an underprivileged peasant household framed the disability of the physically impaired farmer. It did so in a quite different way than it did later on when Árni and his wife abandoned the farmstead and moved to the village of Húsavík, where Árni ended up commuting in a "deluxe model" of 
a hand propelled motor carriage. At Viðasel on the other hand, Árni had no support equipment to aid his mobility, save for some ropes he used for pulling himself up to a raised position (Jakobsson 1963). However, because of the architectural structure of the cottage, the baðstofa being the social space for working, eating, sleeping, engaging in cultural activities, etc., he was quite active in terms of participation. Brown et al. (2004, p. 463) define participation as referring to "engagement in activities that are intrinsically social, that are part of household or other occupational role functioning, or that are recreational activities occurring in community settings." From this perspective it seems reasonable to conclude that as regards the turf-house, in comparison with standardised modernised design, the former had fewer disabling effects on the person with physical impairment than the latter. Vernacular architecture of the past, because of the nature of its structure and its plasticity and lack of standardisation, can thus be seen, to an extent, as more in tune with the differing demands of diverse human bodies.

\section{References}

Anon., 1924. Æfiminning Ásmundar Ásmundssonar 1845-1924. Heimskringla, 17, 2-3.

Brown, M., Dijkers, M., Gordon, W. A., Ashman, T., Charatz, H., Cheng, Z., 2004. Participation objective, participation subjective: A measure of participation combining outsider and insider perspectives. Journal of Head Trauma Rehabilitation, 19 (6), 459-481.

Chang, F. H., and Coster, W. J., 2014. Conceptualizing the construct of participation in adults with disabilities. Archives of Physical Medicine and Rehabilitation, 95 (9), 1791-1798. Doi: 10.1016/j.apmr.2014.05.008

CRPD., 2006. United Nations Convention on the Rights of Persons with Disabilities. New York: United Nations.

Emilsson, T., 1976. Fátakt fólk: Aviminningar. Reykjavik: Mál og menning.

Finkelstein, V., 1981. Disability and the helper/helped relationship: An historical view. In: A. Brechin et al., eds. Handicap in a Social World. Sevenoaks, UK: Hodder \& Stoughton in association with the Open University Press, 65-78.

Gíslason, M., 1977. Kvällsvaka: En isländsk kulturtradition belyst genom studier $i$ bondebefolkningens vardagsliv och miljö under senare hälften av 1800-talet och början av 1900-talet. Uppsala: University of Uppsala.

Gleeson B., 1999. Geographies of Disability. Routledge: London and New York.

Gleeson B., 2001. Domestic space and disability in nineteenth-century Melbourne, Australia. Journal of Historical Geography, 27 (2), 223-240. Doi: 10.1006/ jhge. 2000.0300

Guðjónsson, S., 2013a. Aðbúnaður geðveikra á Íslandi og umbatur yfirvalda fyrir daga geðspitala. Thesis (PhD). University of Iceland.

Guðjónsson, S., 2013b. Í “öruggri” vist eða förufólk? Hlutskipti fólks með geðsjúkdóma á Íslandi á 19. öld. In: H. B. Sigurjónsdóttir, Á. Jakobsson and K. Björnsdóttir, eds. Fötlun og menning: Íslandssagan i öðru ljósi. Reykjavik: Félagsvísindastofnun Háskóla Íslands og Rannsóknarsetur í fötlunarfræðum, 127-144. 
Gunnlaugsson, G. Á., 1983. Löggjöf um fátækraframfærslu á Íslandi á 18. öld. Saga, 21, 39-72.

Gunnlaugsson, G. Á., 1988. Family and household in Iceland 1801-1930. Studies in the relationship between demographic and socio-economic development, social legislation and family and household structure. Uppsala, SE: Acta Universitatis Upsaliensis.

Gunnarsson, G., 1987. Upp er boðið Ísaland. Einokunarverslun og islenskt samfélag 1602-1787. Reykjavik: Örn og Örlygur.

Guttormsson, L., 2008. Fræðsluhefðin: Kirkjuleg heimafræðasla. In: L. Guttormsson, ed. Almenningsfræðsla á Íslandi 1880-2007. Reykjavik: University of Iceland Press, 21-25.

Hafsteinsson, S.B., 2010. Museum politics and turf-house heritage. In: G.P. Jóhannesson and H. Björnsdóttir, eds. Rannsóknir í félagsvísindum XI. Reykjavik: Félagsvísindastofnun Háskóla Íslands, 266-273

Hafsteinsson, S. B., 2019. "Icelandic putridity": Colonial thought and Icelandic architectural heritage. Scandinavian Studies, 91 (1-2), 53-73.

Hafsteinsson, S. B., and Jóhannesdóttir, M. G., 2015. Moldargreni og menningararfur: Útrýming og arfleifð torfhúsa. In: Ó. Rastrick and V.Tr. Hafstein, eds. Menningararfur á Íslandi: Gagnrýni og greining. Reykjavík: University of Iceland Press, 193-218.

Hálfdanarson, G., 2008. Private spaces and private lives: Privacy, intimacy, and culture in Icelandic 19th-century rural homes. In: P. François, T. Syrjämaa and H. Terho eds. Power and culture: New perspectives on spatiality in European history. Pisa, IT: Edizioni Plus, 109-124.

Halldórsdóttir, E. D., 2020. Óhreinu börnin hennar Evu: Holdsveiki á Íslandi og $i$ Noregi. Reykjavik: Ugla.

Imrie, R., 2000. Disability and discourses of mobility and movement. Environment and Planning A: Economy and Space, 32 (9), 1641-1656.

Imrie, R., and Edwards, C., 2007. The geographies of disability: Reflections on the development of a sub-discipline. Geography Compass, 1 (3), 623-640. Doi: 10.1111/j.1749-8198.2007.00032.x

Imrie, R., 2004. Disability, embodiment and the meaning of the home. Housing Studies, 19 (5), 745-763. Doi: 10.1080/0267303042000249189

Ingason, U., 2020. Aerial photographs of Víðasel. At: Pingeyjarsýsla: Archealogical society of Pingeyjarsýsla.

Jakobsson, Á., 1963. Á völtum fótum: Avisaga. In: P. Friðgeirsson ed. Akureyri, IS: Bókaforlag Odds Björnssonar.

Jónasson, J., 2010. Íslenskir pjóðhattir. In: E. Ó. Sveinsson, ed. Reykjavik: Opna.

Jónsson, F., 1914. Ólafur á Kjörseyri og ætt hans. Eimreiðin 3, 176-183.

Jónsson, G., and Magnússon M. S., eds., 1997. Hagskinna. Icelandic historical statistics. Reykjavik: Statistics Iceland

Jónsson, J., 2018. Á mörkum mennskunnar: Viðhorf til förufólks i sögnum og samfélagi. Reykjavik: University of Iceland Press.

Karlsson, G., 2000. Iceland's 1100 years: The history of a marginal society. London: C. Hurst.

Kreps, T., 2019. Sustainability in Cold Climates: A Vernacular Study of Icelandic Turf Houses. Thesis (MA). Laurentian University.

Lárusson, H., 2014. Íslenski bærinn. Tímarit Máls og menningar, 75 (1), 17-35.

Le Goff, J., 1988. Medieval civilization 400-1500. Trans, J. Barrow. Oxford: Blackwell, 1988. 
Macdonald, S. J., et al., 2018. 'The invisible enemy': Disability, loneliness and isolation. Disability \& Society, 33 (7), 1138-1159. Doi: 10.1080/09687599.2018. 1476224

Magnússon, M.S., 1985. Iceland in transition: Labour and socio-economic change before 1940. Lund, SE: Ekonomisk-historiska Föreningen.

Magnússon, S.G., 2019. Hús og híbýli albýðumanna. Fátækt á Íslandi á síðari hluta 19. aldar og fram á pá 20. í máli og myndum. In: F. Jónsson, S. Ólafsdóttir and S.G. Magnússon. Híbýli fátaktar. Húsnæði og veraldleg gaði fátaks fólks á 19. öld og fram á 20. öld. Reykjavik: University of Iceland Press, 15-51.

Metzler, I., 2013. A social history of disability in the Middle Ages Cultural Considerations Of Physical Impairment. Abington, PA: Routledge.

NAIS, 1920. National Archives of Iceland (NAIS) Census Database. Reykjavík: National Archives of Iceland.

Oliver, M., 1990. The Cultural Production of Impairment and Disability. In: M. Oliver, ed. The politics of disablement. critical texts in social work and the welfare state. Palgrave: London, 12-24.

Oliver, M., and Barnes, C., 2012. The new politics of disablement. Basingstoke, UK: Palgrave Macmillan.

Rastrick, Ó., 2012. Postulínshundar og glötuð meistaraverk: Um verkefni íslenskrar menningarsagnfræði á priðja áratug tuttugustu aldar, Ritið, 12 (1), 31-47.

Rastrick, Ó., 2013. Háborgin: Menning, fagurfraði og pólitík í upphafi tuttugustu aldar. Reykjavik: University of Iceland Press.

Shakespeare, T., 2018. Disability: The basics. Abingdon, PA: Routledge.

Sigurðardóttir, S., 2008. Building with turf [online]. Glaumbær, IS, Skagafjörður Historical Museum. Available from: http://hdl.handle.net/10802/6870 [Accessed 1 March 2021].

Sigurðardóttir, S., 2012. Traditional Building Methods [online]. Glaumbær, IS, Skagafjörður Historical Museum. Available from: Glaumbær. http://hdl.handle. net/10802/9062 [Accessed 1 March 2021].

Sigurðardóttir, S., 2020. Viðhorf til nytja- og minjagildis torfbygginga. Rannsóknir um minjaarf I-torfbyggingar. Rannsóknaskýrslur Ferðamáladeildar Háskólans á Hólum [online]. Sauðárkrókur, IS, Háskólinn á Hólum. Available from: https:// www.holar.is/static/files/Rannsoknir/Ferdamaladeild/Utgefidefni/vidhorf_til_ nytja-_og_minjagildis_torfbygginga_loka.pdf [Accessed 1 March 2021].

Snævarr, Á., 2019. Maðurinn sem elskaði Ísland: Paul Gaimard og Íslandsferðir hans 1835-1836. Reykjavik: Mál og menning.

Stefánsson, H., 2013. Af jörðu: Íslensk torfhús. Reykjavik: Crymogea.

Titchkosky, T., 2011. The question of access: Disability, space, meaning. Toronto: University of Toronto Press.

Porbergsson, J., 1917. Ásmundarsaga fótalausa. Eimreiðin, 3, 173-177.

van Hoof, J., and van Dijken, F., 2008. The historical turf farms of Iceland: Architecture, building technology and the indoor environment. Building and Environment, 43 (6), 1023-1030. Doi: 10.1016/j.buildenv.2007.03.004

Víglundsson, P. P., 1969. Hetjan fótalausa og eiginkonan. Blik: Ársrit Vestmannaeyja, $27,40-62$.

Vilhelmsson, V., 2017. Sjálfstatt fólk: Vistarband og islenskt samfélag á 19. öld. Reykjavik: Sögufélag.

Vilhjálmsson, K., 1941. Frá Kristjáni fótalausa. Gríma, 16, 24-29. 
Warrington, M., 2001. 'I must get out': The geographies of domestic violence. Transactions of the Institute of British Geographers, 26, 365-382. Doi: 10.1111/14755661.00028

Wiesel, I., and van Holstein, E., 2020. Disability and place. In: Edensor, T., Kalandides, A. and Kothari, U. eds. The routledge handbook on place. London and New York: Routledge, 304-312. 


\title{
9 Guðmundur Bergpórsson as Creator and Creation: A Folk Narrative Study of a 17th Century Disabled Poet
}

\author{
Alice Bower
}

\section{Introduction}

Guðmundur Bergpórsson (1657-1705) was one of Iceland's most prominent poets of rimur, an Icelandic genre of poetry often dubbed "metrical romances." Thirteen rímur or rímur cycles written by Guðmundur have been preserved, and a significant amount of poetry attributed to him exists both in manuscript collections and in oral recordings from the 20 th century. With some notable exceptions, rímur are poetic retellings of known stories, often drawing inspiration from the Icelandic, Germanic, or European narrative traditions. The format does not allow for as much personal expression as other types of poetry, as the poet principally assumes the role of narrator. However, in the so-called mansöngvar (sing. mansöngur) of rímur, a poet is able to step outside of this role and address the audience directly, often lamenting his own misfortunes in life and love. It is within this framework that Guðmundur Bergpórsson sometimes alludes to his disability.

Over the past 200 years, a folk legend tradition has existed parallel to the artistic legacy of Guðmundur Bergpórsson. In the legend tradition a greater focus is placed on Guðmundur Bergpórsson's physical disability. These legends can be viewed in light of what has been referred to as the suppression of historical identity, which can harm disabled people in history by reducing their lives to presumed ideas about disability, denying their agency in the process of identity formation and effacing the importance of other elements in their character (O'Toole 2010a, p. 13, 2010b). Of all the legends recorded about Guðmundur Bergbórsson during the 19th and 20th centuries, the tale of how he became disabled through magical means is likely the most well-known. Another tale, about Guðmundur's unsuccessful quest to a dwarf to find a cure for his disability, also appears in multiple sources. Legends about Guðmundur Bergbórsson's disability often incorporate his work as a poet. Commonly associated with the story about how he became disabled is a single verse attributed to him (Árnason 1954-61, p. 453, Gíslason 1947, p. 81-82), while his poem Hugarhægð is referenced in a version of the legend about his journey to a dwarf (Davíðsson 
1978-1980, p. 140). In folklore, Guðmundur Bergpórsson is widely called kraftaskáld, an Icelandic term for a poet whose words are magically charged.

Guðmundur Bergpórsson is by no means the only disabled author to leave a significant impact on Icelandic literary culture, or the only known figure to become the inspiration for legends which portray his physical difference in a supernatural or tragic light. The sheer quantity and quality, however, of sources written by Guðmundur Bergpórsson which at times allude to his own life, provides the modern researcher with a rare opportunity to compare and contrast his own representations of himself with those formulated by later generations, helping us to gain insights into the process of legend creation which surrounded disability in Icelandic society of the past three centuries.

\section{Guðmundur Bergpórsson's early years and family background}

Guðmundur Bergpórsson (1657-1705) was born in Vatnsnes in Iceland's North West, one of five children of Porbjörg Guðmundsdóttir (b. 1636) and a man named Bergpór. Among the scant records that exist on his family is a version of the poem Vambarljóð preserved in the manuscript NKS 1894 4 to, in which "a very old woman, the mother of Guðmundur Bergpórsson" is cited as a source (Porgeirsson 2012, p. 182). In the few sources available on Porbjörg Guðmundsdóttir, she appears to have shared her son's interest in literary culture. In Finnur Sigmundsson's introduction to his edition of Olgeirs rímur danska by Guðmundur Bergpórsson, he includes a transcription of a brief biography of the author written in 1770 by Pórður Guðmundsson and Andrés Jónsson, who remember him from their early years. Unfortunately, Finnur does not cite the original manuscript. This account is particularly useful as the authors not only remember interactions with Guðmundur Bergpórsson, but are also well-versed in his poetry and able to connect events in Guðmundur's life to particular works.

Pórður and Andrés describe a good relationship between Guðmundur and his mother. They recall that after Guomundur became disabled at the age of four, he was sent to live elsewhere. He was first at Staðarbakki in Miðfjörður but later migrated west, following his mother who had moved due to poverty. When he was an adult living in Snæfellsnes, his mother would often come to visit him "for her own pleasure" and recite rímur that he had composed as a 12 year old, much to the adult Guðmundur's embarrassment (Sigmundsson 1947, p. 15). Finnur Sigmundsson (1947, p. 22) specifically mentions the poem Vinapökk as a warm expression of Guðmundur Bergpórsson's feelings towards his mother. Vinapökk is preserved in at least six manuscripts, the majority dating from the 19th century. The following discussion is based on my reading of two of these, Syrpa Gísla Konráðssonar from 1850-1870 and Bænir from 1884-1886. Both manuscripts are held at the National and University Library of Iceland under the shelfmarks Lbs 2856 4to and Lbs 2941 8vo, respectively. In the first part 
of Vinapökk, Guðmundur Bergbórsson recalls his life and gives praise to God for the friends and family who have helped him. His account is not without pain, as the sixth stanza tells of how Guðmundur's happy childhood was overset with suffering at around the age of four as he lost almost all his physical strength:

As I spent my childhood as I best could

Blessed God! Who had given me this age

At near four years old

Painful suffering engulfed me

Though I was small

My bodily strength and all of my might (Bergpórsson 1884-1886, 185r). ${ }^{1}$

Up until this point in the poem, he had only described his life and family positively. In stanza five, he refers to the "willing love and friendship of [my] parents." In the seventh stanza, he describes how the devotion of his parents had continued into his adulthood, before proceeding to express gratitude to friends who have helped him. Stanza eleven is likewise dedicated to the virtue and love of his parents (Bergbórsson 1884-1886, 185r, 1850-1870, 119v-120r). Although Guðmundur Bergpórsson refers to both his parents in the above examples, it is noted in Pórður Guðmundsson and Andrés Jónsson's short biography that Guðmundur's father died before Guðmundur reached adulthood and moved west near his mother (Sigmundsson 1947, p. 14). This would indicate that these words of praise would have been most relevant to his relationship with his mother, particularly during his adult years. A later account preserved in Gísli Konráðsson's manuscript Søgupáttr frá Guðmundi skáldi Bergpórssyni (1860, p. 3), held at the National and University Library of Iceland under the shelf mark Lbs 1130 4to, includes more information about Bergbór and references an oral account of a verse allegedly composed by Guðmundur as a child about a mishap suffered by his father at sea. These insights from Guðmundur's poetry into strong family ties, particularly to his mother, are important as they shine a positive light on a relationship which would later emerge as an integral theme in folk narratives about him as it takes on a much darker nature.

\section{Understandings of disability during Guðmundur Bergpórsson's lifetime}

Guðmundur Bergpórsson's works provide valuable insights into the language used and the concepts employed by a 17th century poet when he discusses his own physical impairment. It is nevertheless important to consider his descriptions of life with a disability within the social, cultural, and literary traditions within which he operated. At a first glance, his descriptions 
of his disability and its impact on his life can provide the modern reader with a rather bleak impression of a disabled man's prospects in 17th century Iceland, for example in this lament in the first so-called mansöngur (pl. mansöngvar) of Ótúels rímur:

Of men's strength I have been given

The least of Noah's children

My physical ability does not allow

To make hay, cut crops or row

(Bergpórsson 1952, p. 274).

In the mansöngvar of rímur, a poet is able to step out of their role as a narrator and address the audience directly. Early in the rímur tradition, it had become customary to begin each individual ríma with a mansöngur. Mansöngvar are often formulaic and make use of the same motifs (Ólason 1993, p. 330). Nonetheless, as Sir William Craigie (1952, p. 320) indicates, the originality of a mansöngur is dependent on the poet, with some being able to convey their feelings with a skill that could even possibly be compared to eminent poets of the 17 th and 18 th centuries.

Within the framework of the mansöngur, it is common for poets to complain about misfortunes in their own lives, commonly of a romantic nature. Poets may also draw upon other aspects of their lives and the use of material based on a poet's experience of living with a disability for the traditional lament is not confined to the works of Guðmundur Bergpórsson. Disability in mansöngvar has yet to be thoroughly researched but has not gone unnoticed by scholars of rímur. For example, Björn K. Pórólfsson has drawn attention to the complaint of Rögnvaldur blindi (e. the blind) about his own blindness in Skógarkristsrímur (Pórólfsson 1950, p. 185). In the case of disabled rímur poets, Oliver and Barnes (2012, p. 98) argument, that the personal response of disabled individuals to their impairments "cannot be understood simply as a reaction to 'trauma' or 'tragedy,' but have to be located within a contextual framework that takes account of both history and ideology," can be expanded to cover the stylistic traditions to which they adhere.

The emphasis on Guomundur's own vulnerability seen in the first mansöngur of Ótúels rímur is also to be found in the first mansöngur of the unpublished Bertrams rímur. In stanza 11 he praises God for having supported him for 40 years "so that I neither froze nor starved" (Bergpórsson, p. 1902). This expressed gratitude for his mere survival, placed in the context of his disability, can also be seen in his poem Vinapökk. In the eighth stanza of Vinapökk, Guðmundur expresses gratitude towards those who have housed and clothed him (Bergpórsson 1850-1870, 119v, 1884-1886, $185 \mathrm{v})$. In Guðmundur's own descriptions of his disability, as in later narratives, his age when he became disabled is an important factor. In addition to Vinapökk in which he describes the "painful suffering" which befell him at 
nearly four years old (Bergbórsson 1884-1886, 185r), the final mansöngur of the unpublished Ferakutsrímur, transcribed by Sigmundsson (1947, p. 18), also includes a reference to his age. There he laments his condition which he says he has lived with since the age of four. As will be discussed in further depth in this chapter, narrators of 19th century folkloric texts will use Guðmundur's own references to becoming disabled at aged four to support folk narratives portraying him as a victim of black magic within the home.

In line with the comparatively late establishment of the medical profession in Iceland, understandings of disability developed differently to those in countries which were earlier to industrialise (Smith 2013, p. 93). In pre-industrial Iceland, it was not uncommon for narratives about disability to be framed in a religious or superstitious context. As will be explored further in this chapter, in narratives about Guðmundur Bergbórsson's disability the causes of his physical condition are either unexplained or connected to elusive powers. Nonetheless, certain elements of categorisation which have since been associated with the so-called medical model of disability can be found in narratives about Guðmundur dating back to Pórður Guðmundsson and Andrés Jónsson's 1770 biography. In his analysis of the medical model, the sociologist Tom Shakespeare writes that this approach focuses on physical difference and conceives of disability as the outcome of impairment, as well as being likely to group disabled people in terms of individual impairments (Shakespeare 1996, p. 95). These observations both hold true when narratives about Guðmundur Bergpórsson are studied. Adjectives used to describe him point to a specific impairment rather than a general status as a disabled individual. This appears to have been a common approach in Iceland at the time, as the idea of a disabled community with diverse physical, sensual, and mental differences did not exist as it does today.

Guðmundur Bergpórsson is widely referred to by adjectives that directly reference his impairment, such as visinn, which signifies a condition of physical deterioration. In Pórður Guðmundsson and Andrés Jónsson's biography, more extensive physical descriptions are also to be found in which differences between Guðmundur's body and a preconceived norm are underlined. They write that Guðmundur had "legs as long as an adult man which were both skinny and powerless" (Sigmundsson 1947, pp. 14-15). Here, the authors perception of how legs are supposed to function colours his description of Guðmundur's body, drawing the reader's attention to how it differs. They write that the only part of his body which remained unaffected by his disability was his left arm below the elbow. Everything he wrote was, therefore, written with his left hand (Sigmundsson 1947, pp. 13-15). This description fits particularly well with two key elements of the medical model identified by Shakespeare (1996, p. 95), namely performing and conforming. The observation that Guðmundur was able to write with his left hand is also emphasised in much younger texts, such as Pórarinn Eldjárn's novel Kyrr Kjör (1983, p. 69) and even appears in Finnur Sigmundsson's (1966, p. 49) 
summary of his life and works in an anthology of rímur skálds - a passage which fits onto less than a page. This intrigue with his ability to write is exemplified in Finnur Sigmundsson and Björn K. Pórólfsson's 1947 edition of Olgeirs rímur danska by Guðmundur Bergbórsson, which includes two photographs of Guðmundur's handwriting (Bergpórsson 1947).

In a passage of Pórður and Andrés' biography most likely written by Pórður; a description is to be found of how Guðmundur's condition impacted his ability to take part in daily life on the farm. There we can see that in addition to carving out a role for himself as a teacher and a poet, Guðmundur adapted his physical abilities to fit with the kind of work required of farm inhabitants:

Others told me, that he most often paid to be carried, particularly to church, and those who carried him, as well as ourselves who often carried him, said that he was of a similar weight to a half-grown man. He was good at brass work and woodwork. He did and was able to do all wool production apart from weaving, but he found spinning the hardest, so that was most often done for him by others

(Sigmundsson 1947, pp. 14-15).

The seemingly mundane detail that Guðmundur allowed himself to be carried would later form a crucial part of the legend of his quest to be healed by a dwarf. As is the case with Guðmundur's own references to having been four years old when he became disabled, the inclusion of this detail in legends recorded during the 19th and 20th centuries serves the purpose of endowing them with greater credibility through association with the testimony of Guðmundur Bergbórsson and those who remembered him.

\section{A tale of childhood disability, family ties, and magical healing}

An early folk narrative about Guðmundur's childhood in Pórður Guðmundsson and Andrés Jónsson's 1770 biography betrays supernatural understandings of the nature of disability. In this passage, which Finnur Sigmundsson indicates was written by pórður Guðmundsson, Pórður remembers being taught by Guðmundur Bergpórsson to read at the age of thirteen. He recounts the following story:

He himself recalled, [that] after he became ill in the North, his grandmother advised that he should be put into three hot springs and washed thrice in each of them. After that he improved greatly and his body softened, and never did his disabled condition (ice. visna) or weakness become greater than they had been at that point, so that when he was 14 or 15 years old, he could crawl between farmsteads that were close together

(Sigmundsson 1947, p. 14). 
According to the dates given in Pórður and Andrés' account, Guðmundur Bergpórsson would have moved to Hólsbúd around the late 1690s and stayed there for six years. This means that Pórður's recollection of this story is written around 70 years after he remembered it being told. If this story is to be trusted, it supports other testimonies both in Pórður and Andrés' biography and in Guðmundur's own work of a strong relationship with his family members, particularly women. It would also offer an insight into the attitude of a disabled person towards an experience of a folk medicine practice.

Balneology, the treatment of disease by immersion in baths or mineral springs, appears in a variety of sources spanning cultures and millennia (Shalinsky 1985). In the introduction to her analysis of this practice in the 20th century, the anthropologist Audrey C. Shalinsky (1985, p. 35) connects what she identifies as a "widespread association between life, health and taking in a liquid" to the practice of balneology. She cites folklorist Alan Dundes' analysis of the importance of the wet/dry binary in relation to the evil eye belief system in Semitic and Indo-European cultures. Dundes (1992, p. 298) writes that consequences for the victim of the evil eye tend to involve a drying or withering process. He concludes his analysis by arguing that there is "ample evidence to support the notion that the opposition between wet and dry is a fundamental folk idea, albeit an unconscious one, in Indo-European and Semitic world view, a folk idea which is, metaphorically at any rate, a matter of life and death". With regard to hot spring folk healing practices, Shalinsky $(1985$, p. 35) writes that this method of curing "includes the application of heat in addition to wetness. It is likely that a double binary opposition, wet/dry and hot/cold, underlies Indo-European ideas about health and life."

Shalinsky's application of the binary approach to curing methods using hot springs fits particularly well with Pórður Guðmundsson's narrative, as the Icelandic noun "visna," which I have translated as "disabled condition," is related to the verb "visna," meaning "to wither." In Pórður's account, the bath halted this process. The idea that his body became softer or more relaxed upon receiving this treatment can also be understood in relation to the hot/cold binary, with cold temperatures often being associated with rigidness and frigidity. It is worth noting that the adjective "visinn," also derived from "visna," is used widely to describe Guðmundur's condition, even appearing alongside his occupation as a poet on the 1703 census (Hagstofa Íslands 1924-47, p. 105). Degrees of separation between the informant and the subject of this narrative, as well as the substantial amount of time in between the incident having purportedly taken place, told, and then retold, make it difficult to attribute any greater meaning or value to it than that of a narrative recorded in the latter half of the $18^{\text {th }}$ century. The language used and the elements which the narrator places emphasis on should first and foremost be viewed in the historical and cultural context of Pórður Guðmundsson's lifetime. 
However, if indeed Guðmundur Bergpórsson was brought as a child to three pools in an attempt to reverse or mitigate the effects of his illness, this would not have been the only case of the use of hot springs for medicinal purposes in Icelandic folk culture. In Jónas Jónasson's Íslenzkir pjóðhattir (1961, p. 322), a book on Icelandic folklife compiled during the second decade of the 20th century, the use of dry hot springs is documented as a practice intended to cure rheumatism. While the use of hot springs for medicinal purpose can now be easily identified as a folk healing process as opposed to a scientific one (Shalinsky 1985, p. 34), it is important to consider that this distinction is difficult to apply to Icelandic society of the 17 th and 18th centuries. Medical doctors did not officially practice in Iceland before 1760 and the few medical books that existed were not available to the majority of the population (Jónasson 1961, p. 312-313). This left people such as Guðmundur's family with little alternative to folk cures when illness struck. As the folklorist Laura Stark (2006, p. 315) writes in her analysis of folk healing in early modern Finland, unexpected illness poses a problem for cultural categories of experience as it disrupts the coherence of meaning in everyday life. It is, therefore, conceivable that a family would have sought a supernatural or otherwise unexplained cure for an illness that they most likely could not identify the reason behind.

Whether or not this account of Guðmundur's grandmother's attempt to ward off his illness has any basis in his own lived experience, the tale seems to have resonated to some degree with audiences of the subsequent three centuries. It is recounted in Gísli Konráðsson's manuscript Søgupáttr frá Guðmundi skáldi Bergpórssyni (1860, p. 2) and Ólafur Davíðsson’s Íslenzkar pjóðsögur (1978-1980, p. 139), collected around the turn of the 20th century. More recently, the author Pórarinn Eldjárn included this episode in his novel Kyrr kjör, in which Guðmundur Bergpórsson is the protagonist. Eldjárn (1983, p. 10) has described the novel as fiction which draws on real characters from Guðmundur's life, as well as folktales.

In Eldjárn's retelling of this event, a link is made to another wellknown folk legend about Guðmundur Bergpórsson, as it emerges that Guðmundur's grandmother had obtained her knowledge of this cure in her younger years from dwarfs. With regard to the effect it had on his illness, Eldjárn connects it directly to Guðmundur's ability to write with his left hand. In Kyrr Kjör, Guðmundur says "it was in this way that I gained the strength that I have in my left hand" (Eldjárn 1983, p. 69). By connecting Guðmundur's means of transmitting poetry to the work of dwarfs, Eldjárn evokes mythological connotations of dwarfs as enablers of poetry and wisdom. In Snorri Sturluson's Prose Edda (1998, p. 3), it was the dwarfs Fjalar and Galar who killed Kvasir to make the mead of poetry from his blood. Pórarinn Eldjárn's modern reworking of this story can help to provide an insight into what it is about this tale which has captured the popular imagination for centuries after it allegedly took place. The idea of a remarkable poet being saved at the eleventh hour from an unknown fate by mysterious 
forces perhaps serves to allow readers to approach his works with greater wonder, as lines are blurred between the poet himself and the extraordinary worlds he tells of. The disabled experience, meanwhile, is portrayed as an unexplained misfortune consigned to the realm of miracle-workers. Disability is associated with the magical, creating distance between the societies which tell and consume healing narratives and the reality of disability.

\section{The mother's curse and the dwarf's flight: two 19th century folk legends}

Of the later folk legends about Guðmundur Bergpórsson, the tale of how he became disabled is one of the most widely documented. The earliest published version of this tale appears in Jón Árnason's Íslenzkar pjóðsögur og evintýri, which was first printed in 1862 with a revised edition released in the 1950s (1862-4, p. 468, 1954-1960, p. 453). Interestingly, a detailed description of Guðmundur's physical disability, not dissimilar to that in Pórður Guðmundsson and Andrés Jónsson's 1770 biography, appears in Jón Árnason's manuscript of Íslenskar pjóðsögur og avintýri from 1850-65, which is preserved at the National Library of Iceland under the shelf mark Lbs 529 4to (46v, 49r). This description is absent from the published version, in which the story of how he became disabled through magical means appears first, followed by a short legend about his ability to curse others through his poetry and then a longer narrative about his quest to be healed at the hands of a dwarf. As well as the physical description, additional information on topics such as his life at Arnarstapi, how he became literate, his handwriting, his physical abilities and his work as a teacher is included in Jón Árnason's manuscript (1850-65, 50r-50v), but absent in the published version. As in earlier texts, in the manuscript there is an emphasis on the ways in which Guðmundur was able to adapt his surroundings to give him a better quality of life. This is particularly apparent in the following description of a cart he used for transportation:

And so, he had to either let others carry him or push him in a cart, which was made for this purpose. The morning that the bishop was expected to come to Stapar, Guðmundur had let himself be pushed out in his cart, as looking at nature brought him joy

(Árnason 1850-65, 50v).

The omission of such descriptions in the published anthology could likely be the result of an emphasis placed by the Icelandic collectors and their foreign colleagues on ancient knowledge, as described by the folklorist Terry Gunnell (2010, pp. 22-24). In Íslenzkar pjóðsögur og avintýri, the story of Guðmundur Bergbórsson is reduced to three distinct events, leaving out various episodes relating to his magically charged poetry, amongst which the description of the cart is to be found. Although it is to be expected that 
a large corpus of folktales would be edited and refined for publication, often at the expense of more mundane or biographical details, it is worth considering the effect that such a decision would have had on the image of Guðmundur Bergpórsson in the public imagination.

In the version documented in Íslenzkar pjóðsögur og avintýri of how Guðmundur became disabled, two variants are given. In both, it is a female caregiver who is the cause of Guðmundur's disability:

The poet Guðmundur Bergpórsson was disabled (visinn) on one side as is well known, and it is the testimony of most men that his ill health came about when he was near four years of age and still slept in a cradle by his parents at Stapar, which was then common for children up until the age of six or seven. His mother, who was considered odd in her ways, and his childminder, who was also of ill temperament, exchanged frightening words and curses while the cradle was in between them. Others say that his mother had cursed him and that her words had become magically charged, rendering him a cripple for the rest of his life. In connection with this, Guðmundur widely makes reference in his poetry and in the mansöngvar of his rímur to having been in good health in the beginning of his life and he also appears to scold bad women as if they had done something to deserve it

(Árnason 1954-60, p. 453).

The sources given for this account are the poet Bólu-Hjálmar (1796-1875) and the priest Skúli Gíslason (1825-1888). In Skúli Gíslason's folklore collection (1947, pp. 81-2), the version in which Guðmundur's mother caused his disability by cursing him in a fit of rage is detailed. The motif of the mother cursing her young son is not without precedent in Icelandic narrative tradition, and in Harðar saga ok Hólmverja the protagonist's bad luck is attributed to a curse bestowed upon him by his mother. In Harðar saga (1991, pp. 16-7), as in the tale of Guomundur Bergpórsson, the short description of the curse is followed by a verse, in this case attributed to the mother. In the legend of how Guðmundur became disabled, as will be seen in the tale of his quest to a dwarf, old motifs from the existing narrative corpus are employed by legend narrators. In the case of the mother's curse, the use of this particular motif underlines Guomundur's strong connection with poetry, whilst portraying his disability as the result of black magic.

Both variants of this legend are accompanied by a short verse attributed to Guðmundur Bergpórsson and interpreted as a reference to this event. The feminine plural form of the adjective "gustkaldur" (bitter cold) used in this verse, in the context of being bitter cold or harsh in their words, is particularly interpreted in Íslenzkar pjóðsögur og avintýri to denote a female influence (Árnason 1954-1960, p. 453). This interpretation is also present in Gísli Konráðsson’s manuscript Søgupáttr frá Guðmundi skáldi Bergpórssyni (c. 1860, p. 2). In this source, as well as in Jón Árnason's 
manuscript (1850-65, 49r-49v), a second verse appears which is also connected to this tale, in which Guðmundur allegedly recalls having been healthy in the beginning of his childhood. As can be seen in the published text in Íslenzkar bjóðsögur og avintýri, Guðmundur's own reference to the sudden nature of his disability is presented by narrators of folk legend as evidence of black magic. Here it could be argued that as is the case in legends about changelings, it is the change in an apparently healthy child which sparks connections with magical or hidden powers in the popular imagination (Schoon Eberley 1988, p. 61, Lindow 2008, pp. 216-217). A third variant of this legend was recorded on tape by the folklorists Hallfreður Örn Eiríksson and Svend Nielsen and is held at the Árni Magnússon Institute in Reykjavík under the shelf mark SÁM 84/90. The informant, Kristrún Porvarðardóttir (b. 1873), was from Arnarstapi in Snæfellsnes, the area where Guðmundur spent much of his adult life. In the version she tells, two women were arguing as one of them held Guðmundur. This caused his asymmetrical growth (Porvarðardóttir 1965). While these accounts vary as to exactly who cursed Guðmundur Bergpórsson and whether he was the intended target, they all identify a female culprit within the sphere of the home.

The image of the innocent child cursed with physical impairment conforms to what has since been labelled the "personal tragedy" model of defining disability (Drake 1999, p. 10). In addition to this, the idea of the healthy child rendered disabled by a mother's actions, either during pregnancy or in a child's formative years, is well-documented in folklore. In her analysis of congenital defects in folk belief, Susan Schoon Eberly details two types of explanation for children being born with disability. The first focuses on the conscious and unconscious thoughts of the mother, while the latter involves the mother breaking a taboo (Schoon Eberly 1988, pp. 59-60). In Icelandic pregnancy superstition documented during the 19th and 20th centuries there is also a heavy emphasis on things the mother can do to which cause disability in the unborn child (Jónasson 1961, p. 259). This gendered trope can also be identified in modern discourse on an international level, as the phenomenon sometimes referred to as "mother blame" has been applied to studies on disabled children (Francis 2012, Bell et al. 2009). Writing in a modern context, the sociologist Ara Francis (2012, p. 928) says that "along with mothers who are single, poor, non-White, immigrant, homeless or lesbian, women whose children are 'disabled,' or 'deviant' are frequently judged to be bad mothers." When the scant information that is available to the modern reader on Porbjörg Guðmundsdóttir is taken into account, it appears possible that other elements of her life related to her social status, such as her poverty and becoming widowed early, could have contributed to the process of othering which occurs in folk legends, in conjunction with her son's disability.

It is no surprise that narratives about the magical origins of Guðmundur's disability are often followed by accounts of his search for a magical cure-a 
healing balm owned by a dwarf (dvergur). In Íslenzkar pjóðsögur og avintýri, the following passage is attributed to an Andrés Jónsson, most likely the same man who wrote Guðmundur's biography alongside Pórður Guðmundsson in 1770. The original source quoted is oral in nature, and would likely fill the modern criteria for a "friend-of-a-friend" narrative:

It has been said of a man who was called Andrés Jónsson and lived in Andrésarbúð, close to Hólsbúð where Guðmundur was, that he had said his friends in the north the following story:

"When I was around 20 years of age, I heard Guðmundur say that now there were only two dvergar left in Iceland; one of them lived in a cliff in Langanesströnd and the other was his neighbour and lived in a large stone close to Hólsbúð. He had the balm which could heal him so that he would be healthy again if he could only obtain it, though he suspected that the magic of the curse which had been laid upon him in his innocence would not be easy to shake off." It was one summer on a holy day that most people went to church, apart from Guðmundur who stayed home and Andrés who was with him. Then Guðmundur said to Andrés: "Now I wish to make a deal with you, my friend, as you have proven to me your secrecy and reticence. You must now carry me eastwards from the settlement to the large stone which stands there, to which I will direct you." The boy said that he would do that. They then prepared to leave, and Andrés carried him and put him down opposite the stone which Guðmundur had indicated

(Árnason 1954-60, p. 454).

At the core of this description is the help which Guðmundur received from men such as Andrés with mobility. As has been covered earlier in this chapter, Andrés Jónsson and Pórður Guðmundsson described how he would make deals with able-bodied men to carry him to church, with no reference to the episode in which Guðmundur allegedly asked to be carried to a dwarf's stone. The motif of encounters taking place on holy days between supernatural beings and the person left at the farm while others are at church is common in Icelandic folklore. Unlike in the story of Guðmundur, these legends most commonly take place at Christmas time and a key feature is that the spirits come into the sphere of the home (Gunnell 2002). Nonetheless, the holy timing and consequent absence of others can be understood as an indication that the tale of Guðmundur's quest may be related to this better-known legend tradition.

In the version of the narrative published in Íslenzkar pjóðsögur og avintýri, Andrés Jónsson is asked to leave shortly after placing Guðmundur down by the stone. Before he goes, he is given instructions not to tell anybody of Guðmundur's whereabouts. Later that day, a man came to Hólsbúð looking for Guðmundur, who he believed could cure his daughter of insanity caused by ghosts or evil spirits. Andrés lied that he must have allowed himself to 
be carried to church as he often did. Eventually, Andrés agreed to look for Guðmundur and came across the following scene:

He then walked to the place where he had left Guðmundur and saw that he had lured the dvergur out of his stone and towards his cart with a large box of balm in his hand. The dvergur was so surprised when he saw the man that he disappeared like lightening into his stone, which quickly closed around him

(Árnason 1954-60, p. 454).

In a paper about folk legend and belief on the Snæfellsnes peninsula, Terry Gunnell writes that this legend "takes the form of international migratory legends telling of people unsuccessfully attempting to dig up buried treasure that is protected by some form of enchantment (ML 1810). In each case, the treasure-hunters are disturbed at the last moment by something that distracts their attention." He notes that such legends are relatively common in Iceland, and not least in Snæfellsnes (Gunnell 2020, p. 51). When we consider how other folk narratives about Guðmundur Bergpórsson's life draw heavily from established folk narrative motifs and ideas, Gunnell's observation fits particularly well.

To those familiar with Icelandic folklore, the dwarf's stone as the setting for such a tale might appear unusual. The legend of Guðmundur Bergbórsson is one of only three legends in Íslenzkar pjóðsögur og avintýri featuring dwarfs. While dwarf legends are more common in later folk narrative collections, they are nonetheless still relatively rare. The highest concentration of dwarf legends can be found in the Westfjords and the East. When they do appear, they either play a similar role to elves or hidden people (álfar and huldufólk) or they act similarly to their ancestors in the legendary sagas (Bower 2019). In legendary sagas, dwarfs are presented as gatekeepers, possessors of treasure, folk healers, and magicians. It is in this category that the dwarf allegedly sought by Guðmundur can be placed.

The appearance of a dwarf as the elusive treasure - or facilitator thereof is interesting not least because of the well-established connections between dwarfs and disability. In Icelandic, as in English, the use of the word dwarf to refer to magical creatures or spirits has existed alongside its connotations of physical disability since the middle ages. The first clear use of the word to describe a person of unusually short stature appears in the 13th century kings' saga Morkinskinna, in which a human is said to have been "as short as a dwarf and thick set." The term "til sýnis" (e. on exhibit) is used, indicating that the man was some kind of a court marvel (Unger 1867, p. 94). Subsequently, others have been identified as dvergur in the absence of supernatural characteristics, in particular in translated chivalric sagas such as Erex saga Artuskappa and Ívens saga (Blaisdell 1965, pp. 6-8, Blaisdell 1979, p. 114). 
That having been said, the vast majority of dvergar in medieval and folkloric Icelandic texts preside over supernatural characteristics, either with or without mention of physical difference. In the case of Guðmundur's quest, the dwarf is a supernatural being and is not presented as disabled. However, the connection between dvergar and disability in medieval Icelandic literature and later folk narrative is multifaceted and often extends beyond the dwarf's body. As a healer, the dwarf cures the physically sick and disabled. The use of a healing balm owned by a dwarf for this purpose appears in Göngu-Hrólfs saga (1944, p. 417). Immediately after introducing the balm, its owner Möndull says that he is a dwarf who lives in the earth, and that he possesses "dvergsnáttúra" (e. a dwarf's nature) with regard to medicine and craftsmanship. The dwarf's balm has since cropped up in literature and folk narratives (Laxdal 2006, p. 413-415, Bjarnason and Gíslason 1954-9, p. 91-94).

It is worth noting that narratives about dwarfs who heal tend to focus on sudden illness and disability, often relating to trauma. For example, in Egils saga einhenda ok Ásmundar berserkjabana (1944, p. 174-175), the one-handed Egill seeks a dwarf's help to heal his stump. After doing this, the dwarf makes him a sword which is designed to work as if his arm were whole. Similarly, in the much later folktale of the one-legged shepherd boy, a dwarf restores an amputee's leg (Jónsson 1964-5, p. 195-198). Possibly the earliest example of dwarfs using their craftmanship to restore or compensate for a traumatic physical loss is to be found in Snorri Sturluson's Skáldskaparmál (1998, p. 41), in which they restore the hair of Sif which is cut off by Loki. In all of these narratives, the physical characteristic restored by the dwarf was at one point present, and the loss involved some sort of trauma and/or violence; that is to say, integral to the motif of the dwarf who heals appears to be a patient who was not born disabled, but rather became so at some point in his life. It is, therefore, fitting that in the beginning of the narrative of Guðmundur's quest, he reminds Andrés Jónsson (and by extension the audience), that the curse was laid upon him "in his innocence" (Árnason 1954-60, p. 454). In Jón Árnason's manuscript $(1850-65,50 \mathrm{v})$, the word "áfall," meaning trauma or shock, is also used to refer to Guðmundur's illness.

While the story of Guðmundur Bergbórsson is told in a way that fits comfortably with older saga motifs about disability and healing, the emphasis on his own powers as a folk healer in Íslenzkar pjóðsögur og ævintýri can be harder to put into a pre-established narrative context. They appear to be an extension of his magical abilities as a kraftaskáld and are not prominent in the oldest narratives about Guðmundur. It is very possible that one narrative role played by this attribute is that of tragic irony. This irony, underlining the idea of disability as personal tragedy, is prominent in Jón Árnason's Íslenzkar pjóðsögur og evintýri when it is explicitly stated that he "was just short of being able to use [his skill] to heal his own illness" (1954-60, p. 454). Around 100 years later, it is conveyed in Kristrún 
Porvarðardóttir's oral narrative (1965), which she ends with the words "He was a fine healer, although he couldn't help himself."

\section{Conclusion}

Guðmundur Bergpórsson's prominence as a poet allowed him to play an active role in shaping his own life narrative for future generations. Through his works, he directly addressed his contemporaries and offered a glimpse, if only fleeting, into his own lived experience as a disabled man. In a short biography written over 60 years after his death by two men who had known him as children, droplets of Guomundur's agency in the narrative are still discernible as his poems and memories are referenced. His daily life is detailed in a way that can be humanising, though at the same time influenced by the social attitudes to disability of the era. As time passes from Guðmundur Bergpórsson's death, however, legends begin to form about this distinctive public figure, and it becomes clear that some motifs and ideas have particularly captured the popular imagination. In Jón Árnason's manuscript Lbs 529 4to, written over 150 years after Guðmundur's death, folktales are mixed in with detailed descriptions of Guðmundur's physical appearance and everyday life. Due to what we can only assume were editorial decisions, only three legends about Guðmundur made it into the final publication of Íslenzkar pjóðsögur og avintýri. Of these three, two focus on the cause and possible cure of his disability which are both magical in nature. As well as connecting disability to the supernatural, these two legends play on the tropes of disability as personal tragedy and childhood disability as a result of maternal abuse or negligence. It is these tales which were to leave a profound mark on vernacular narratives of Guðmundur's life well into the 20th and 21st centuries, as the majority of Guðmundur's own poetry remains unpublished.

\section{Note}

1. All translations are the author's own

\section{References}

Árnason, J., 1850-65. Íslenskar pjóðsögur og avintýri. [Manuscript-online] Available at: https://handrit.is/en/manuscript/view/is/Lbs04-0529 [Accessed 05.05.2021]. Lbs 529 4to.

Árnason, J., 1862-4. Íslenzkar pjóðsögur og afintýri. Vol. I-II. Leipzig, DE: J.C. Hinrichs.

Árnason, J., 1954-1960. Íslenzkar pjóðsögur og avintýri. Vol. I-VI. Reykjavík: pjóðsaga.

Bell, K., McNaughton, D., and Salmon, A., 2009. Medicine, Morality and Mothering: Public Health Discourses on Foetal Alcohol Exposure, Smoking Around Children and Childhood Overnutrition. Critical Public Health, 19 (2), 155-170. 
Bergbórsson, G., 1884-1886. Banir: Vinapökk. [Manuscript-online] Available at: https://handrit.is/en/manuscript/view/is/Lbs08-2941 [Accessed 25.05.2021]. Lbs 29418 vo.

Bergpórsson, G., 1902. Rímnakver: Rímur af Bertram. [Manuscript] Held at: Reykjavík: National and University Library of Iceland. Lbs 5070 8vo.

Bergpórsson, G., c. 1850-1870. Syrpa Gísla Konráðssonar: Vinapökk. [Manuscriptonline] Available at: https://handrit.is/en/manuscript/view/is/Lbs04-2856 [Accessed 25.05.2021]. Lbs 2856 4to.

Bergpórsson, G., 1952. Mansöngvar: Ótúels rímur I. In: W. Craigie, ed. Sýnisbók íslenzkra rímna. 2nd edition. London: Thomas Nelson and Sons, 273-276.

Bjarnason, A., and Gíslason, O., 1954-1959. Vestfirzkar pjóðsögur. Vol I-III. Reykjavík: Ísafoldarprentsmiðja.

Blaisdell, F., ed., 1965. Erex saga Artuskappa. Copenhagen: Munksgaard.

Blaisdell, F., ed., 1979. Ívens saga. Copenhagen: Munksgaard.

Bower, A., 2019. "Litil fremd er pér pað að brjóta i mér mín stuttu bein": Rannsókn á einkennum, varðveislu og próun dvergasagna á Íslandi frá miðöldum til nútímans. Thesis (MA). University of Iceland.

Craigie, W., 1952. Sýnisbók Íslenskra rímna: Frá upphafi rímnakveðskapar til loka nitjándu aldar: Vol. II. London: Thomas Nelson and Sons.

Davíðsson, Ó., 1978-1980. Íslenzkar pjóðsögur: Bindi 1-4. In: P.M. Jónsson, ed. Reykjavík: Pjóðsaga.

Drake, R., 1999. Understanding Disability Policies. Basingstoke \& London: Palgrave Macmillan.

Dundes, A., 1992. Wet and Dry, the Evil Eye: An Essay in Indo-European and Semitic Worldview. In: A. Dundes, ed. The Evil Eye: A Casebook. Madison, WI: University of Wisconsin Press, 257-312.

Egils saga einhenda ok Ásmundar berserkjabana., 1944. In: G. Jónsson and B. Vilhjálmsson, eds. Fornaldarsögur Norðurlanda 3. Reykjavík: Bókaútgáfan Forni, 153-190.

Eldjárn, P., 1983. Kyrr kjör. Reykjavík: Iðunn.

Francis, A., 2012. Stigma in an Era of Medicalisation and Anxious Parenting: How Proximity and Culpability Shape Middle-Class Parents' Experiences of Disgrace. Sociology of Health and Illness, 34 (6), 927-942.

Gíslason, S., 1947. Sagnakver Skúla Gíslasonar. In: S. Nordal, ed. Reykjavík: Helgafell.

Gunnell, T., 2002. Komi peir sem koma vilja...: Sagnir um innrás óvætta á jólum til forna á íslenska sveitabæi. In: B. Hafstað and H. Bessason, eds. Úr manna minnum: greinar um íslenskar pjóðsögur. Reykjavík: Heimskringla, 191-209.

Gunnell, T., 2010. Daisies Rise to Become Oaks. The Politics of Early Folktale Collection in Northern Europe. Folklore, 121, 12-37.

Gunnell, T., 2020. Invisible Force: The Absence of Folk Legends About Snæfellsjökull. In: M. Egeler and S. Gropper, eds. Dreaming of a Glacier: Snafellsjökull in a Geocritical Perspective. Munich: Utzverlag GmbH, 43-63.

Göngu-Hrólfs saga., 1944. In: G. Jónsson and B. Vilhjálmsson, eds. Fornaldarsögur Norðurlanda II. Reykjavík: Bókaútgáfan Forni, 359-461.

Hagstofa Íslands., 1924-1947. Manntal á Íslandi: Árið 1703. Reykjavík: Ríkisprentsmiðjan Gutenberg.

Harðar saga., 1991. In: P. Vilmundarson and B. Vilhjálmsson, eds. Harðar saga: Íslenzk fornrit XIII. Reykjavík: Hið íslenzka fornritafélag, 1-97. 
Jónasson, J., 1961. Íslenzkir pjóðhattir. Reykjavík: Ísafoldarprentsmiðja.

Jónsson, P.M., 1964-1965. Gríma hin nýja: Safn pjóðlegra fraða islenzkra. Vol. I-V. Reykjavík: Pjóðsaga.

Konráðsson, G., 1860. Søgupáttr frá Guðmundi skáldi Bergpórssyni. [Manuscript] Held at: Reykjavík: National and University Library of Iceland. Lbs 1130 4to.

Laxdal, E., 2006. Ólandssaga. In P. Antonsson and M.A. Porsteinsdóttir, eds.. Reykavík: Háskólaprent.

Lindow, J., 2008. Changelings, Changing, Re-Exchanges: Thoughts on the Relationship Between Folk Belief and Legend. In: T. Gunnell, ed. Legends and Landscape: Articles Based on Plenary Papers Presented at the $5^{\text {th }}$ Celtic-Nordic-Baltic Folklore Symposium, Reykjavík 2005. Reykjavík: University of Iceland Press, 215-234.

O'Toole, M., 2010a. Disability and the Suppression of Historical Identity: Rediscovering the Professional Backgrounds of the Blind Residents of the Hôpital des Quinze-Vingts. In: J. Eyler, ed. Disability in the Middle Ages: Reconsiderations and Reverberations. London: Routledge, 11-24.

O'Toole, M., 2010b. The povres avugles of the Hôpital des Quinze-Vingts: Disability and Community in Medieval Paris. In: M. Cohen and J. Firnhaben-Baker, eds. Difference and identity in Francia and Medieval France. Farnham, UK: Ashgate, 157-174.

Oliver, M., and Barnes, C., 2012. The New Politics of Disablement. Basingstoke, UK: Palgrave Macmillan.

Ólason, V., 1993. Kveðskapur frá síðmiðöldum. In: V. Ólason, ed. Íslensk bókmenntasaga II. Reykjavík: Mál og menning, 283-378.

Schoon Eberley, S., 1988. Fairies and the Folklore of Disability: Changelings, Hybrids, and the Solitary Fairy. Folklore, 99 (1), 58-77.

Shakespeare, T., 1996. Disability, Identity and Difference. In: C. Barnes and G. Mercer, ed. Exploring the Divide. Leeds, UK: The Disability Press, 94-113.

Shalinsky, A., 1985. Thermal Springs as Folk Curing Mechanisms. Folklore Forum, 18 (1), 32-58.

Sigmundsson, F., 1947. Formáli I: Um Guðmund Bergpórsson. In: G. Bergpórsson, ed. Olgeirs rímur danska: Bindi 1. Reykjavík: Landsbókasafn Íslands \& Ísafoldarprentsmiðja, 11-23.

Sigmundsson, F., 1966. Rímnatal I-II. Reykjavík: Rímnafélagið.

Smith, E., 2013. Í skuld við fjölskyldu og Guð. Staða fatlaðs fólks fyrir upphaf læknisfræðilegs skilnings á Íslandi. In: H.B Sigurjónsdóttir, Á. Jakobsson and K. Björnsdóttir, eds. Fötlun og menning: Íslandssaga i öðru ljósi. Reykjavík: Félagsvísindastofnun \& Rannsóknarsetur í fötlunarfræðum, 93-128.

Stark, L., 2006. The Magical Self: Body, Society and the Supernatural in Early Modern Rural Finland. Folklore Fellows Communications, 138 (290), 11-521.

Sturluson, S., 1998. Edda: Skáldskaparmál I. A. Faulkes, ed. London: Viking Society for Northern Research.

Unger, C.R., ed., 1867. Morkinskinna. Christiania, NO: Bentzens.

Porgeirsson, H., 2012. Poetic Formulas in Late Medieval Icelandic Folk Poetry: The Case of Vambarljóð. RMN Newsletter, 4, 181-196.

Porvarðardóttir, K., 1965. Sögn um baklun Guðmundar Bergpórssonar og dverginn i berginu, 21.08.1965. [Audio recording- online] Available at: https://www.ismus. is/i/audio/id-1001377 [Accessed 25.05.2021]. SÁM 84/90 EF.

Pórólfsson, B.K. (1950. Dróttkvæði og rímur. Skírnir, 124 (1), 175-209. 


\title{
10 Fictive Osteobiographical Narrative - The Missing Puzzle Pieces
}

\author{
Haraldur Thor Hammer Haraldsson
}

\section{Introduction}

You were always different than others. Born without complete use of half your body, your path through this life was never easy. Your mother once confided in me that, in a moment of weakness after a very difficult labour, she momentarily considered sparing you a lifetime of hardship by abandoning you, to place, and leave you outside, as was once done with some infants like you. Fortunately for you, me, and your sons, your parents kept faith in our Lord, bolstered by the sight of how tenacious for life you were, with strong cries and a healthy appetite.

Researching disability in the past is not an easy undertaking. The modern understanding of the term does not truly conform to how different bodied people might have been treated, and how they might have viewed themselves in the past. How they would have identified themselves might not be the same as with modern people who are physically different. Therefore, it might be prudent to try to cast off the modern preconceptions of what disability is and how it is constructed today in order to maintain a modern scholarly professionalism and objectivity, while also trying to fill the inevitable yet important blank spots. When researching the past through archaeological investigations, one of the largest issue's researchers have to deal with is what is not there, what is missing. In the effort of filling in these blank spots, where information has been lost to time for one reason or another, subjective insertions from the researcher might become inescapable. This chapter approaches the subject of the physically different in the past from a bioarchaeological starting point, or from the skeleton, then branches outwards from it by touching upon several other academic spheres. This purpose of this effort is not to only catalog and describe physically different people of the past, but to gain insight into their social conditions, their embodied experiences, and the contemporary societal views towards the different. The excerpt here above is from the finished story about a man called Grímur and who is the focus of this chapter. To construct such a story a detailed investigation has to be conducted, a research which starts with the bones 
of a certain individual. To a bioarchaeologist, human remains can provide a plethora of meaningful information. However, there are questions which can be difficult to address while only studying physical remains. When a skeleton exhibits symptom of osteoarthritis, or fractures, some degree of pain must have been experienced by the person, but which raises questions that are difficult to answer: How much pain? How long did the period of felt pain remain? Did the pathologies observed on the bone affect those around the person somehow? How did others perceive this physically different person? These sorts of questions are important when studying disability but cannot be answered through the bones alone. In the attempt address such questions in an academic manner, a study of more than just the bones are required.

In this chapter I want to describe a little-known method that has begun to receive some attention in recent years, but is, in itself, not new. It started as a method, or model, called the archaeologies of personhood, which derived from feminist studies on the role of gender, and it demonstrated that it was possible to apply archaeological investigation to understand the unobservable. Its application draws from various aspects of archaeological and bioarchaeological investigations to build and comprehensive account of a person's life (Clark and Wilkie 2006, p. 333-364). I believe that this method is an invaluable tool for archaeologists, osteologists, palaeopathologists, and any other researcher wanting to get a deeper understanding of the lived lives of past people. Anthropologist Alexis Boutin took this model one step further by introducing the aspect of storytelling, or a biographical narrative, by constructing what she calls a "fictive osteobiographical narrative" (Boutin 2016, p. 17-28). This relies on the researcher dealing with the inevitable missing evidence and apply a restrained addition of fiction to compensate for what is missing from the archaeological record. The downsides and potential pitfalls of this method of constructing an account for a person's life will be discussed as well. These missing pieces are issues archaeologists have always had to wrestle with. Items and artefacts are often found out of context, their origin or function unknown, they have been altered or, more often, are missing. It is extremely rare to find a site that is preserved in the same state it was in while in use by the people who lived there at the time. Furthermore, the people who inhabited the excavated structures are seldomly found within the context of the structures, but rather in local cemeteries or burial sites, making any direct connections between a person and structure improbable. However, here is where multifaceted investigations help to make the improbable plausible. One such approach, which is the focus of this chapter, is "fictive osteobiographical narrative," which is a method to describe a physically different person that utilises an analysis of human remains, research of contemporary information, and also adds fictive elements to provide a holistic account of the person's embodied experiences.

Such osteobiographical narratives call for an investigation of a broad number of research areas. This process could be described as assembling 
a puzzle where some of the pieces are missing. First, a palaeopathological and osteological analysis on the skeletal remains would be conducted and if possible, chemical analysis for strontium, oxygen, nitrogen, carbon, and lead isotopes, which are often obtained from tooth enamel samples. Such analytical results can provide information, for example, about where people spent their first years in life and what their main sources of food. A DNA analysis could also be informative, providing additional support for pathological and skeletal analysis. Conventional archaeological information gathered from excavating housings, cemeteries, or other sites along with artefacts and surveys of the local environment can provide vital insights into past people's cultures, lives, and behaviours. However, as previously stated, archaeological data can seldom give a complete picture of the past. Contemporary literary sources can be a treasure trove of information to fill in the gaps, even though they often do not mention different bodied people. Even though direct references to the different bodied are scares, it does not necessarily imply that they are not to be found. By shifting the approach of the inquiry and ask different questions, because a complete absence of something that was undeniably present can be telling. These questions can be something like this: Are different bodied people purposely being neglected in the records? Did the writers of these documents just not care enough? Or perhaps, did people not consider "different bodies" to be "different enough" to actually make the effort to write about? Contemporary literary sources are not without their faults, which is outlined in another chapter in this volume (Crocker et al., 2021, See Chapter 1). With all the above in mind, let us start a journey together, to see how an account can be constructed about a person's life, experiences, feelings, and views. Let's start from the body, work our way out from it, then end our trek through time by looking back.

\section{Bones: the corner pieces of the puzzle}

The first pieces we need to assemble our puzzle, as with most puzzles, would be the corner pieces, which in our case would come from examining the person we are studying. The information that can be obtained from skeletal remains is quite impressive. The biological age at death can be estimated from observations of various developmental markers on several skeletal elements. Biological sex can be assessed, and diseases, trauma, congenital conditions, and syndromes can be documented from morphological indicators from bones (Brothwell 1981, p. 59-73, Van Beek 1983, Hillson 2005, 2008, Işcan et al. 1984, p. 853-863, Meindl and Lovejoy 1985, p. 57-66, Brooks and Suchey 1990, p. 227-238). This information can give great insights into how a person's life could have been, how long a person lived and what sort of activities they might have performed, by assessing fractures and muscle attachments or signs of human diversity perceivable on the bones. An idea of a person's livelihood or occupation can be formed by examining certain impairments or physical differences 
which produce observable traces, or occupational markers, on skeletal elements through repetitive physical activity (Kennedy 1989, p. 129-160, Weiss 2004, p. 232-238, Katzenberg and Saunders 2008, Villotte et al. 2010, p. 224-234). Dominant handedness can also be asserted (Steele 2000). Teeth and some bones can tell us if a person endured malnutrition during their development (Hillson 1996, Temple et al. 2012 p. 1640). Using more invasive investigative methods can even be more informative. A DNA analysis can provide evidence for pathological diagnosis and hereditary connections (Ricaut et al. 2004, p. 116-121, Lewis 2007, p. 35, Ebenesersdóttir et al. 2018, p. 1028-1032). Isotopic analysis can also be very informative. They can give estimates on where a person grew up and what their diet was mainly composed of (Elias et al. 1982, p. 2561-2579, Blum et al. 2000, p. 99, Budd et al. 2001, p. 311-322, Montgomery 2010, p. 326, Voerkelius et al. 2010, p. 938). The analysis of the skeletal remains of our individual, Grímur, exhibited signs of a prolonged paralysis in the entire left side of his body, or hemiplegia, with no evidence of trauma. The differential diagnosis of his remains indicate that he had either congenital or acquired Cerebral Palsy, or CP. Since there is no direct causal event responsible for the CP, such as severe head trauma, it is possible to provide a hypothesis within the narrative of the fictive story, seen at the beginning of this chapter, for the presence of the hemiplegia most likely resulting from being born with CP.

To start out the procedure of building a fictive osteobiography, the skeletal remains of an individual must be present. Grímur's remains were excavated at a Christian cemetery named Skeljastaðir, which is situated in the Pjórsárdalur valley in the southern inlands of Iceland. The volcano Hekla erupted in 1104, blanketing the valley with volcanic ash. The exhumation of Grímur showed that the ash layer of 1104 was deposited after his burial, giving us a time frame for his burial from between ca. 1000 and 1104. Osteo- and pathological analysis indicated that this was a robust male of $45+$ years. There was moderate to severe osteoarthritis throughout the skeleton, with no signs of trauma or infectious diseases. The left humerus, femur and tibia were both shorter and thinner than their right counterparts, indicating a form of paralysis or hemiplegia which would have been present for a considerable amount of time. Interestingly, osteoarthritis was observed in the affected left foot, which could indicate that the foot was used to some extent. All this information is garnered from the skeleton, but there are other means of investigation that help to understand the individual and their contemporary surroundings, methods that can uncover what is missing, so that the assembly of the puzzle can begin.

\section{Archaeological investigations: artefacts and environment - structural pieces}

The second piece we need to understand is how a person lived and moved through the local space, and to do so we would preferably want to investigate contemporary houses and living conditions. Since Grímur's remains were 
excavated at a cemetery, we cannot connect him directly to any farmstead excavated in the bjórsárdalur valley. By studying the excavation reports, drawings, and layout of farmsteads and how the buildings were structured, it can give us information for how a body, such as this man's, could move through the space these buildings. Archaeological investigations can yield an enormous amount of data from multiple different spheres of research. Item or artefacts inform on several aspects, such as availability of materials, movement of valuables, manufacturing techniques, and presumed value of materials. This information would provide the backdrop for our story, the puzzle pieces showing what surrounds the individual gleaned from data gathered from research. An example of such research comes from the excavation at Hofstaðir, northern Iceland. Extensive research was conducted on the site which spans several hundreds of years of occupation (Lucas 2009). One aspect of the research focused on the material remains of the site and their origins (Batey et al. 2009, p. 309). The examinations of structures inform on construction techniques and therefore the effort needed to erect buildings for various purposes. Building materials are sometimes gathered from far outside the local area, indicating that much effort was extended to move the material. Occasionally the application of spatial analysis has been applied in an effort to understand how a human body might have moved through a space of a particular archaeological structure (Smith, Marshall and Pearson 2001, p. 265, Chesson 2012, p. 45-73, Gillings, Hacigüzeller and Lock 2020, Rastrick in this volume). Environmental survey and research on roads and travel can give an estimate for how people might have traversed their land and give insight into the contemporary economic and political structure (Nordal 1990, Friðriksson and Vésteinsson 1999, p. 6-8, Thorláksson 2000, McGovern et al. 2007, p. 35-38, Einarsson and Aldred 2011, p.243-255).

Other avenues to gain information about the past can be through zooarchaeology, which can inform on people's diets, social and economic interactions, occupation regarding animals, movement of animals and grazing (Bond 1996, p. 85-86, McCormick 2008, p. 215, Pálsdóttir 2008, p. 111-124, Ogilvie et al. 2009, p. 74, O'Connor 2010, p. 1-13, Russell 2012, p. 297-325). Archaeobotany, or the archaeology of ancient flora, utilise remains of plants, seeds and pollen that can give important information for agriculture, domestication, socio-economic structures, and diet (Menzies 2006, p. 87-106, Guðmundsson 2009, p. 322-334, Antolín, Berihuete and López 2016, p. 1-3). Maritime archaeology studies ancient docks and berths, fishing practices and sea travel that can be indicative of trading between faraway places and diet of people (Edvardsson and Egilsson 2011, p. 9-28, Westerdahl 2013, p. 732-762).

Lastly, the natural environment the person might have moved through during life, the local terrain must be considered. Presumably, in a preindustrial society, walking, horse-riding, and boats were the three main modes of transportation. In Iceland, there have been no archaeological finds to support any other modes of transport, such as carts or carriages. Data 
gathered from archaeological investigations alone cannot give comprehensive account for a person's experiences and views, nor the contemporary social and cultural constructs which a person interacted and intersected with. To find such pieces of our puzzle, we need to broaden our search area from the bones, grave and archaeology to other academic fields that research the past. Conveying such data in our fictive osteobiographical narrative can be written thusly:

I could not have been more pleased with the area on which we had placed our home, within this flat and accessible ground since it did not hinder you much in your work in or around our farm. Our home, small as it was, was one of your favourite places. The narrow space provided you with support wherever you stood, freeing you from the unwanted pressure to seek help from others.

\section{Literature: legal, religious documents, and sagas - background puzzles}

By expanding the scope of the investigation, if possible, it would be prudent to consider contemporary literary works. Law books illustrate the legal framework to which peoples and societies conform, which would provide us with the third type of puzzle pieces. Furthermore, they show how certain behaviours resulted in debilitating punishments and how the legal and social obligations affected the populace and how specific groups would, could or should be treated. These puzzle pieces form the background for our story, where the person is situated within our frame and illustrates the connection between the individual and the society. For Grímur's case, there is no contemporary legal document existing today. We do have, however, documents written shortly after his time which can be retrofitted to Grímur's era. The book named Grágás (Gray Goose laws) was in effect in Iceland presumably from the settlement period (ca. 870 AD) to shortly after 1260, when Iceland's governance was taken over by the Norwegian Crown. As a tool for legal justice, it is quite comprehensive and detailed. The subject of disability as we understand it today is never mentioned within the pages of Grágas. The largest chapter in Grágás is the Ómagabálkur (Dependant's charter). This chapter stipulates who are legally responsible for people who cannot provide for themselves, people who for one reason or another are dependent on others for their survival. The definition for who are considered "dependents" is not specified, making it plausible that people who have physical and/ or mental impairments would or could be defined as a dependent under this stipulation. This would mean that such people would have a legal right to be provided for to ensure their survival. What is interesting about this stipulation is that if a person who is legally obligated to provide for a dependent but neglects their duties, they can face severe legal fines. 
Legal documents and constructs are not the only administrative facet which can impact a person. Religious practices, belief systems and theological decrees towards disability, impairment or different bodied people can be very insightful. When Grímur was alive, around 1000 and 1100 $\mathrm{AD}$, Christianity was the official faith in Iceland. Iceland converted to Christianity in the year 1000, but before that it is believed that most worshipped the deities of the Old Norse pantheon. Examining the Old Norse pantheon from the viewpoint of disability and disability studies is very interesting. The Norse gods have been studied extensively which highlighted the fact that many of these deity's exhibit both physical impairments and cognitive differences to what was likely considered normal (Bragg 2000, p. 128-143, Jónatansdóttir 2013, p. 27-49). Considering the period of Grímur, it is very likely that cultural remnants and knowledge of the former religion was known to Grímur, including awareness of gods with impairments. However, we must acknowledge that during his life, the prevailing religious entities of the Christian faith (God, Jesus, and saints) did not display any significant forms of impairments, at least overtly. Several saints had impairments which did not seem to affect their social or religious status (Lee 2014, p. 45). This is important since it can provide insight into how a person might view themselves and their bodies within their own religious context. We know that during the latter part of the middle ages in Europe there were high standards for the physical aesthetic for Christian priests, so much so that having certain physical impairments could prevent one for becoming a member of the clergy (Swanson 1998, p. 166). Such sentiments within a respected community, such as the clergy, towards different bodied people might have reverberated through the society to some degree.

As stated before, there are often elements missing from the archaeological record due to various factors, such as taphonomy, or natural processes that can cause matter to deteriorate. Iceland is fortunate enough to have a special literary corpus called the Íslendingasögur (often simply referred to as the sagas) or special family sagas, written between the $11^{\text {th }}$ and $13^{\text {th }}$ centuries. Using this corpus can be difficult and problematic, with several issues scholars have to be aware off (Crocker et.al., 2021 in this volume). If we look again at Hofstaðir with consideration to roads, travel, and commerce, some interesting questions come to mind. There is evidence of materials, such as specific stones, that are only found many kilometres away, which was somehow brought from their original deposits to Hofstaðir. No archaeological evidence has been found for wagons or carriages in Iceland during the medieval period. However, there are a few literary references to the use of wagons in the sagas. In Gunnars Saga Keldugnúpsfifls, it says: "Gunnar var pá mjög sár. Lagði borbjörn hann í vagn og óku peir honum heim" (Gunnar was then gravely wounded. Thorbjorn laid him in a wagon, and they drove him home) (Anon 2007, ch. 4). A wagon is also mentioned in Vigaglúms Saga (Anon 1956 ch. 23). 
There is also evidence of other forms of assistive devices in the Sagas. In Brennu-Njáls Saga, a use of a staff as a walking aid is mentioned when Pórhallur Ásgrímsson suffers a lasting injury to his ankle (Anon 1954, ch. 135). This same chapter also mentions that, since Pórhallur is unable to go a ping by himself to aid in legal matters, he is provided with an escort of twenty men, to ensure that he gets to the ping safely. This sort of references is important for several reasons. Firstly, it implies that people used items to aid their maneuverability when they became impaired. Secondly, items, such as staffs and carriages are extremely hard to find in archaeological contexts. Therefore, such references provide insinuations that such items were in fact used, while modern day researchers have no physical evidence for their existence. Be that as it may, it is still an interesting stipulation regarding impairments. To weave such information into a fictive osteobiographical narrative for Grímur would look like this:

Both our sons were born while you were away. Our firstborn came into this world while you were traveling back from ping. The distance to the ping, shorter for you than most other, still was long and difficult for you, even with your trusted walking staff. The Lögmaður secured men to travel there with you, as well as to take care of the farm while you attended ping, a courtesy befitting your station. Even though you needed these men, you always disliked asking for assistance, no matter the situation, even refusing to utilise the wagons. These men you had stationed at the house were very diligent, maintaining the household while I recovered from childbirth.

\section{The missing puzzle pieces}

Even with this plethora of data and references, a full, holistic account can never be constructed with any degree of confidence. Some information is always lost to us. What is found and observed is never everything that was present during the time period being investigated. Buildings are abandoned, leaving only fragments from its usage behind. Bones can be affected, moved, or destroyed via natural processes. Human remains found in one particular cemetery cannot be directly allocated to the local area of that cemetery, since people are often mobile. It is also not possible to observe emotions from skeletal remains. Ideals and beliefs are intangible but important to a person's identity and their own notions about their society and their place within it. This would comprise our fourth and last types of puzzle pieces, and unfortunately, pieces we do not have. Here is where the fictive part comes into the investigation - an estimation or understanding person's embodied habitus as well as the habitual and religious practices that must be achieved to build the foundation for a person's life story. The term "habitus" is used here both in the context of the archaeology's term for a body's physique, while also referring to the concepts of body habitus by Pierre Bourdieu, where the body is regarded as the physical embodiment 
of cultural habits and activities (Bourdieu 1986, p. 241-258). The only emotion or feeling that can be inferred from skeletal remains with any degree of certainty would be physical pain, but pain is not the only emotion people experience through life. Happiness, loss, anger, joy, and love are emotions shared throughout humanity and through time but is seldomly address in archaeological context. The missing pieces represent what has been lost, not available, and the intangible. These pieces, while our individual was alive, existed but are inaccessible to us today. With the certainty that this information once existed, we can connect together what we know, what we have, to see what these missing pieces could have looked like. With all of the possible data that can be gathered from the sources mentioned here above, and with conscious subjectivity put in the mix, we can begin to construct our fictive osteobiographical narrative.

\section{Ethical considerations - Why do the puzzle?}

Before delving into the murky waters of educated and subjective speculations, I want to step back for a moment. It is prudent to be aware of the ethical consideration whilst discussing a person. The first point I want to mention is naming the skeleton. Within the context of archaeological archiving, the individual discussed in this chapter, Grímur, is labelled as PSK-A-040, with the PSK indicating the excavation site and 040 is assigned by the excavators, often by the order in which the individuals were excavated, this person being the $40^{\text {th }}$ during that project. This method is widely practiced and accepted, and for most intents and purposes valid. However, since this project is focused on gaining understanding on a personal level, I found it appropriate to not use this serial number when discussing matters revolving around the remains. Therefore, within the confines of this project, I decided to give the remains a different label, or Grímur. This is an old male name which several men documented in the Landnámubók (the book of settlers) held. The name has also a specific meaning, which will be discussed later in this chapter. The ethical considerations are perhaps apparent. Using an incorrect name, given to him without consent and perhaps assigning a personality or emotions that are wrong or not his own. I would argue that consistently invoking the serial number when referring to a person has its own ethical considerations and does, to a degree, dehumanise human remains.

Other ethical issues which should be addressed are the matter of staring and displaying. By this I am referring to the researcher looking, or observing a person in, arguably, its most vulnerable state or naked to the bone. A typical trend within bioarchaeology is to take pictures of the whole available skeleton when it has been articulated, in other words laid out on a table. This sort of documentation and presentation is an accepted practice within the sphere of bioarchaeology. I would, however, want to invite researchers to reconsider this approach. Within disability studies there is an interesting discussion on the topic of staring, where people 
with different types of bodies experience being stared at by others, with the accompanying feeling of being different, strange, unwelcome, or feared. This relates to people being objectified and being put on display, which has been discussed in the context of medical photographs for instance (GarlandThomson 2006, p. 178, Renwick et al. 2016, p. 283-291). In line with my approach to human remains as being people, even though I know and understand that they are dead, I approach them as being alive, and treat them with the same respect I would treat a living person. Therefore, I only present pictures of specific skeletal elements and from a specific, nonrevealing angles that underline a specific point I want to focus on that aids to my illustration of the account I am presenting (see Figure 10.1).

But why do all this? Why gather all this information and just "fill in the blanks"? This is a valid consideration, for who are we to assert authority about a person who cannot rebut or disagree? Researchers of the past have always done this to a certain degree, make interpretations based on careful research. I would contend that the method described in this chapter is a valid step in the process and progress of scientific inquiry, based in an academic field which straddles empirical and nonempirical investigations, and where some of the variables are unavailable.

\section{Grímur: assembling the puzzle}

The puzzle is now ready to be assembled. We have an adult/middle aged man with hemiplegia who most likely was a local to the Pjórsárdalur valley. He died before the eruption of mount Hekla and was buried in a Christian cemetery. This is valuable information since its settlement, Iceland had no centrally established religion and was largely pagan. This changed in 1000 AD when it peacefully accepted the Christian faith (with some exemptions to begin with, such as consumption of horse meat was still allowed as well as child abandonment). This means that after 1000 AD Christian burial practices began to take over from the prior practice of mound and boat burials. This gives us a relative time period for when this man was alive, between 1000 and 1104. The second pieces would be associated artefacts. No grave goods were recovered from Grímur's grave, and no artefact have been found in Iceland, in an archaeological context, that can be attributed or connected with disability. References to such items can be found in literary sources, such as staffs and wagons.

Excavated, contemporary structures, ideally located locally to where the remains were found, can provide insightful information. Knowing the type of different body being studied, and having a layout of a structure, as well as the local terrain that body might have had to move through can help us understand the obstacles that person faced within a home, and how those obstacles might have been overcome. The last tangible puzzle pieces are 


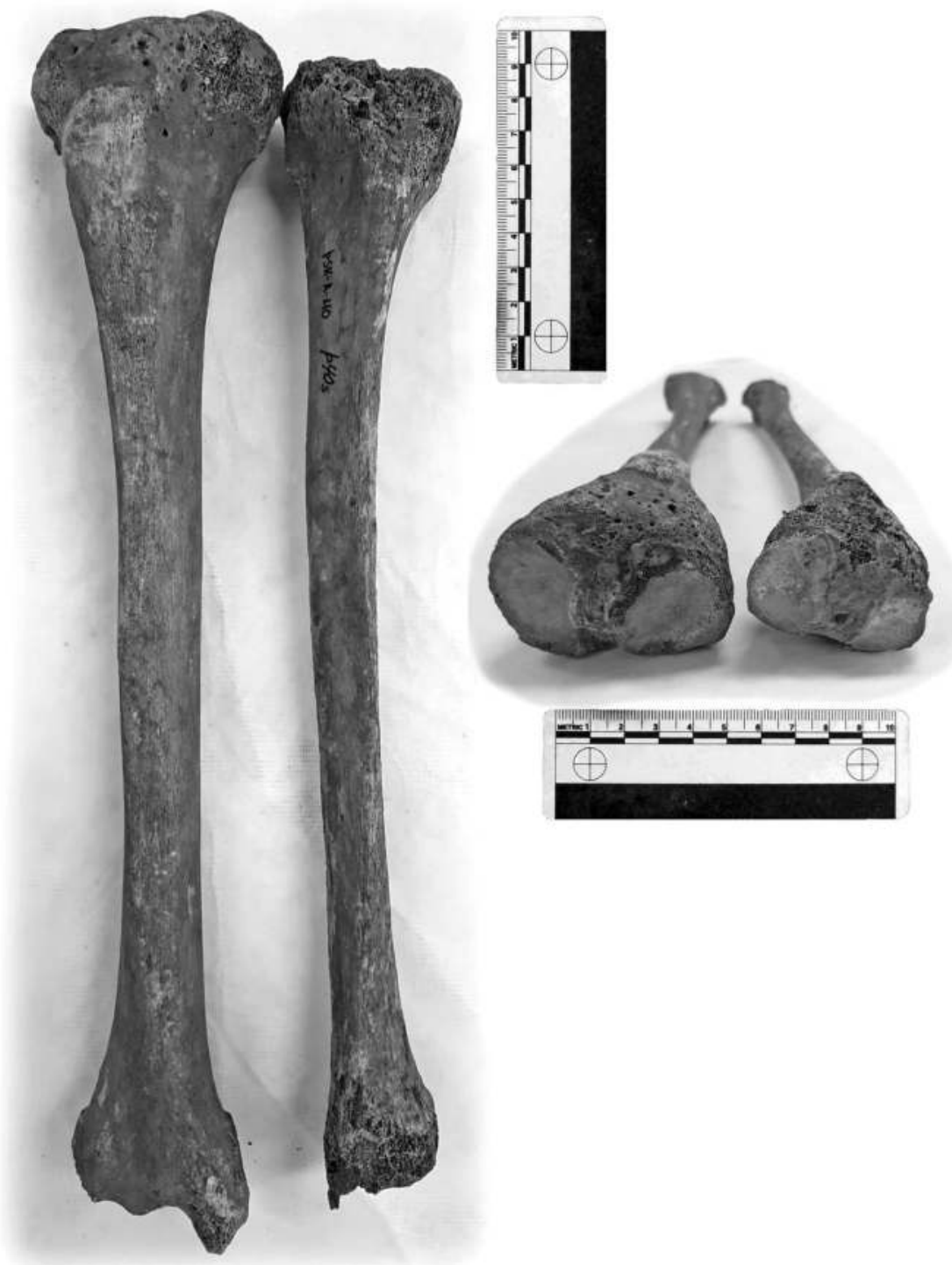

Figure 10.1 Grímur's tibiae. Right tibia is much smaller, shorter, and thinner than its counterpart. The picture only shows what is necessary to convey relevant information without putting the whole person on display. The picture is taken by this author with the permission of the National Museum of Iceland. 
literary sources. These must be as contemporary as possible, so they convey relevance. Legal documents provide insight into how society might have viewed different bodied people. Sources, such as the sagas provide cultural context, and religious texts can be informative for how a governing institution viewed different bodied people. All of these literary sources can also infer to us how a different bodied person might have viewed itself within their contemporary society. Seldomly having a high social status as a group, different bodied people are often hard to find in medieval literary contexts, as in the case of Grágás and the Íslendingasögur. The absence, or lack of direct references to the different bodied in the sagas is at first glance a bit striking. However, if one looks deeper into these texts, whilst simultaneously disregarding the modern-day conceptions of disability or impairment and seeks to understand the contemporary perceptions towards the different bodied, these literary works can provide a plethora of valuable and relevant information. Their apparent "silence" can speak volumes.

\section{Grímur's story: how the pieces fit together}

Before showing you an excerpt from the fictive osteobiographical narrative of Grímur, I would like to reiterate that this text is constructed by amassing data from multiple different sources. All names for people, and all people mentioned except for Grímur are fictive, and the story is being told through Grímur's fictive wife. In an effort to humanise the skeletal remains of individual PSK-A-040, I assigned them a different label, a human name. That name was Grímur. It has historical roots in Iceland, with several men in the Book of Settlers (Landnámabók) named Grímur. The name is also the plural of the word "gríma," or mask. I found the name very fitting, both for its historical presence, and that everyone wears metaphorical masks in everyday life, or roles. We are simultaneously parents, siblings, spouses, workers, leaders and so on. We also have a tendency to mask our emotions from others, even those that are close to us.

The narrative is set in Pjórsárdalur valley, which is where Grímur's remains were found. All mentions of experiencing pain are derived from the estimation of pain which can be attributed from having hemiplegia. This text should not be taken as the truth, but rather as a possible truth, the most plausible version of how the person, known within this project as Grímur, might had experienced life. Within the text are specific references which are explained below, which give the text more depth.

My father brought our family to Kári's farmstead on his way to Ping ${ }^{1}$. My mother and my siblings stayed at your home while the grown men attended bing. I remember how shy you were, how apprehensive you were of my reaction to your faltered speech and crippled body, but as the days passed your nervousness subsided more and more. ${ }^{2}$ Once you told me, long after, that it was my smile which put ease into your heart. 
Proud, stubborn fool. You toiled and stressed your body everyday beyond its limits. You knew your sons were old enough to help cutting the peat, ${ }^{3}$ yet you insisted on doing the labour alone. Exerting your body to the brink of exhaustion to pay for a sin, for that is why the Lord bestowed your coil with such hardship, you said. I know that stiffness in the back often comes with age ${ }^{4}$ but you even did not allow yourself to acknowledge that fact. Sitting by the long fire ${ }^{5}$ with the scarlet flames highlighting the creases of that hardened face, I see that you are not only in pain, but physically drained, and mentally depleted. You are so versed and insistent in hiding it from the world around you, for reasons I have never fathomed. How I wish that you could take off this mask ${ }^{6}$ and be yourself, be it only around your wife, for a wife always knows, always sees, always cares.

\section{Conclusion - a visible image from a fractured puzzle}

Probably the most important notion one must keep in mind while constructing a fictive osteobiographical narrative is to be aware of one's preconceived ideas for what constitutes as disability. The term disability is, in a sense, fluid. It changes through time, and its definition is often different between geographical areas. This is particularly true today, with several schools of thought regarding what constitutes or precipitates disability. This could also hold true for past societies, but their notions towards disability could very well differ from modern views, and this should always be considered.

Humans have evolved in such a way that our brains strive to create and seek out patterns in our surroundings. Therefore, when looking at a puzzle with missing pieces, our brain tries to fill in the voids to create the rest of the image of the puzzle. The more pieces we have access to, the easier that void-filling process is. As Charlotte Roberts (2000) put so eloquently "The attitudes to disease and disability at any particular time period must also be considered, and a multidisciplinary and holistic approach taken, because without one form of evidence, a vital part of the jigsaw may be missing" (p. 57). This method, fictive osteobiographical narrative, is an academic attempt to fill in the puzzle, to recreate those missing pieces. It is not the intent of this project to put the statements made here on a pedestal as they are the only true understanding of each person investigated. They are made with the intention to present the most probable story for an individual with these types of different bodies within the contemporary community, whilst also creating a medium to address seldomly discussed issues within archaeology, such as the effects of pain. When endeavouring to understand a person, someone who is far removed from our own time period, one must aspire, as with any scientific and academic enterprise, to be as objective as possible. Objectivity must be the aim of every investigation, and when studying a person, alive or not, ethical considerations must be observed. 
However, the researcher must also recognise that subjectivity is often inescapable, or even necessary since interpretation is often based on the personal knowledge and experience of the researcher.

Fictive osteobiographical narrative draws together empirical scientific evidence, from osteo- and pathological analysis, archaeological excavations and physical science, and literary references from various sources, and provides a venue for a researcher to address and discuss elements which are, for one reason or another, not available for archaeological observation. Key elements of every research is imagination, without it we would not be able to connect the dots the data brings. Here imagination is given an even bigger role as it becomes a vital tool to move beyond pure analysis to an intricate and narrative interpretation of difference source materials. This method aims to give an as holistic account of a person, or a specific society and their views towards each other. Furthermore, it gives the researcher the opportunity to discuss and debate how those people experienced their own body, their environment and society. Connecting the assembled pieces together enables us to give an estimation for what is missing, whilst also facilitates the possibility for the researcher to acknowledge and examine the intangible and personal. The fictive osteobiographical narrative, albeit a partly fictional, is grounded in the actual. Moreover, it can also touch on how the contemporary society, legal structure and institutions might have interacted and intersected with people with bodies and/or minds which did not conform to the culturally accepted norms. Even though this method adds a fictional element to the study of a person, it is based and structured on empirical and observable evidence. One does not exclude the other, for they are dependent on each other as the evidence themselves do not tell the full story, and a fictional narrative without supporting evidence renders the whole endeavour moot. At the very least, it can initiate a discussion on disability where researchers from various academic fields can participate, for with discussion, debate and understanding, can true progress be made. For the concluding remarks, I would like to give voice to Grímur's wife one last time, for all the effort made here above, was for them:

"When old age had claimed you, I could see through the visor of your expression, as you lay motionless in your cot, that you were at long last serene and without pain. As your story ends, when you are laid to rest on the holy grounds where we were wed, our story will continue."

\section{Notes}

1. A place for meeting to settle legal and other disputes. Also served as a place for local governance. The main ping was called the Alping, which was established in $930 \mathrm{AD}$, was located at Pingvellir. Gatherings there were held regularly and was often concerned with matters affecting the entire country. 
The decision to convert the Icelandic population to Christianity was made there in the year $1000 \mathrm{AD}$. Pingvellir is to the west of Pjórsárdalur, roughly $90 \mathrm{~km}$ away.

2. People with hemiplegia and $\mathrm{CP}$ can often have impaired speech, varying in severity.

3. These areas of turf are rich in decayed organic matter was cut long ribbons and used as fuel, for burning or heating

4. Often referred to as bone spurs, osteophytes commonly increase in frequency with the advancement of age. These bone formations can cause or, in conjunction with other conditions, contribute to impaired movement, discomfort or pain.

5. An open fire pit, most often located in the middle of the main housing compartment, was the main source of indoor heating during early medieval Iceland. They have even been suggested to have been a form of status symbol. Some have been measured to have been up to 5.8 meters long.

6. This is a common Icelandic name in the modern era. The oldest mention of it in Iceland is found in Íslendingabók, in reference to a man named Grímur who settled at Grímsnes. The word grímur has a specific meaning to it. It is the plural of the word gríma, meaning mask. Grímur would therefore translate as masks.

\section{References}

Anon., 1956. Víga-Glúms saga. In: J. Kristjánsson, ed. Svarfdcla saga, Víga-Glúms saga. Reykjavík: Hið Íslenzka Fornritafélag.

Anon., 2007. Gunnars saga Keldugnúpsfífls. In: J. Halldórsson, ed. Kjalnesinga saga, Viglundar saga, Króka-Refs saga, Fórðar saga Hreðu, Finnboga Saga and Gunnars saga Keldugnúpsfifls. Reykjavík: Hið Íslenzka Fornritafélag.

Antolín, F., Berihuete, M., and López, O., 2016. Archaeobotany of wild plant use: Approaches to the exploitation of wild plant resources in the past and its social implications. Quaternary International, 404, 1-3. Doi: 10.1016/j.quaint.2016.01.029

Batey C. E., et al., 2009. The artefactual material. In: G. Lucas, ed. Hofstaðir. Excavations of a Viking Age feasting hall in north-eastern Iceland. Reykjavík: Fornleifastofnun Íslands, 253-321.

Blum, J. D., Taliaferro, E. H., Weisse, M. T., and Holmes, R. T., 2000. Changes in $\mathrm{Sr} / \mathrm{Ca}, \mathrm{Ba} / \mathrm{Ca}$ and $87 \mathrm{Sr} / 86 \mathrm{Sr}$ ratios between tropic levels in two forest ecosystems in the northeastern U.S.A. Biogeochemistry, 49 (1), 87-101. Doi: 10.1023/A: 1006390707989

Bond, J. M., 1996. Burnt offerings. Animal bone in Anglo-Saxon cremations. World Archaeology, 28 (1), 89-98.

Bourdieu, P., 1986. The Forms of Capital. In: J. G. Richardson, ed. Handbook of Theory and Research for the Sociology of Capital. New York: Greenwood Press, 241-58.

Boutin, A. T., 2016. Exploring the social construction of disability: An application of the bioarchaeology of personhood model to a pathological skeleton from ancient Bahrain. International Journal of Paleopathology, 16, 17-28. Doi: 10.1016/j. jipp.2015.10.005.

Bragg, L., 2000. Impaired and inspired: the makings of a medieval Icelandic poet. In: J. Hubert, ed. Madness, Disability and Social Exclusion: The Archaeology and Anthropology of 'difference'. London/New York: Routledge, 128-143. 
Brooks, S., and Suchey, J. M., 1990. Skeletal age determination based on the os pubis: A comparison of the Acsádi-Nemeskéri and Suchey-Brooks methods. Human Evolution, 5, 227-238.

Brothwell, D. R., 1981. Digging Up Bones. 3rd ed. Ithaca, NY: Cornell University Press.

Budd, P., Montgomery, J., Evans, J., and Chenery, C., 2001. Combined Pb-, Sr- and O-Isotope analysis of human dental tissue for the reconstruction of archaeological residential mobility. In: G. Holland and S. Tanner, eds. Plasma source mass spectrometry. Cambridge: Royal Society of Chemistry, 311-323.

Chesson, M. S., 2012. Homemaking in the Early Bronze Age. In: B. J. Parker and C. P. Foster, eds. New Perspectives on Household Archaeology. Ann Arbor, MI: Eisenbrauns, 45-80.

Clark, B. J., and Wilkie, L. A., 2006. The prism of self: gender and personhood. In: S.M. Nelson, ed. Handbook of Gender in Archaeology. Lanham, MD: AltaMira, 333-364.

Crocker, C., Tirosh, Y., Jakobsson, Á., 2021. Disability in Medieval Iceland: Some Methodological Concerns. In: H. B. Sigurjónsdóttir, and J. G. Rice eds. Understanding Disability Throughout History. New York: Routledge, 12-28.

Ebenesersdóttir, S. S., et al., 2018. Ancient genomes from Iceland reveal the making of a human population. Science, 360 (6392), 1028-1032. Doi: 10.1126/science. aar2625

Edvardsson, R., and Egilsson, A. P., 2011. Archaeological Assessment of Selected Submerged Sites in Vestfirðir. Archaeologia Islandica, 9, 9-28.

Einarsson, Á., and Aldred, O., 2011. The archaeological landscape of northeast Iceland: A ghost of a Viking Age society. In: D. C. Cowley, ed. Remote Sensing for Archaeological Heritage Management: Proceedings of the $11^{\text {th }}$ EAC Heritage Management Symposium, 25-27 March 2010 Reykjavík. Brussels: Europae Archaeologia Consilium (EAC), Association Internationale sans But Lucratif (AISBL), Soége social, 243-258.

Elias, R. W., Hirao, Y., and Patterson, C. C., 1982. The circumvention of the natural biopurification along nutrient pathways by atmospheric inputs of industrial lead. Geochimica et Cosmochimica Acta, 46 (12), 2561-2580.

Friðriksson, A., and Vésteinsson, O., 1999. Fornleifakönnun Vegna Fyrirhugaðra Framkvamda i Landi Dingvalla, Svartagils og Brúsastaða - FS088-99071. Reykjavík: Fornleifastofnun Íslands.

Garland-Thomson, R., 2006. Ways of staring. Journal of Visual Culture, 5, 173-192. Doi: $10.1177 / 1470412906066907$

Gillings, M., Hacigüzeller, P., and Lock, G., 2020. Archaeology and Spatial Analysis. In: M. Gillings, P. Hacigüzeller and G. Lock, eds. Archaeological Spatial Analysis: A Methodological Guide. London: Routledge, 1-16.

Guðmundsson G., 2009. The plant remains. In: G. Lucas, ed. Hofstaðir: Excavations of a Viking Age feasting hall in north-eastern Iceland. Reykjavík: Fornleifastofnun Íslands, 322-334.

Hillson, S., 1996. Dental Anthropology. Cambridge: Cambridge University Press.

Hillson, S., 2005. Teeth. 2nd ed. Cambridge: Cambridge University Press.

Hillson, S., 2008. Dental pathology. In: M. A. Katzenberg and S. R. Saunders, eds. Biological anthropology of the human skeleton. 2nd ed. Hoboken, NJ: Wiley-Liss, 249-286. 
Işcan, M. Y., Loth, S. R., and Wright, R. K., 1984. Age estimation from the rib by phase analysis: White males. Journal of Forensic Science, 29 (4), 853-863.

Jónatansdóttir, K., 2013. "Blindur er betri en brenndur sé" Um norræna guði og skerðingar. In: H. B. Sigurjónsdóttir, Á. Jakobsson, and K. Björnsdóttir, eds. Fötlun og Menning - Íslandssagan í Öðru Ljósi. Reykjavík: Félagsvísindastofnun Háskóla Íslands og Rannsóknarsetur í Fötlunarfræðum, 27-49.

Karlsson, G., Sveinsson, K., and Árnason, M., eds., 2001. Grágás - Lagasafn Íslenska Fjóðveldisins. Reykjavík: Mál og Menning.

Katzenberg, M. A., and Saunders, S. R., eds., 2008. Biological anthropology of the human skeleton. 2nd ed. Hoboken, NJ: Wiley-Liss.

Kennedy, K. A. R., 1989. Skeletal markers of occupational stress. In: M. Y. Iscan and K. A. R. Kennedy, eds. Reconstruction of life from the skeleton. New York: Alan R. Liss, 129-160.

Lee, C., 2014. Abled, Disabled, Enabled: An Attempt to Define Disability in AngloSaxon England. Werkstatt Geschichte, 65, 41-54.

Lewis, M. E., 2007. The Bioarchaeology of Children: Perspective from Biological and Forensic Anthropology. Cambridge: Cambridge University Press.

Lucas, G., 2009. Hofstaðir. Excavations of a Viking Age feasting hall in north-eastern Iceland. Reykjavík: Fornleifastofnun Íslands.

McCormick, F., 2008. The decline of the cow: Agricultural and settlement change in early medieval Ireland. Peritia, 20, 209-224. Doi: 10.1484/J.Peri.3.632

McGovern T. H., et. al., 2007. Landscapes of settlement in northern Iceland: Historical ecology of human impact and climate, Fluctuation on the millennial scale. American Anthropologist, 109 (1), 27-51.

Meindl, R. S., and Lovejoy, C. O., 1985. Ectocranial suture closure: A revised method for the determination of skeletal age at death based on the lateralanterior sutures. American Journal of Physical Anthropology, 68 (1), 57-66. Doi: 10.1002/ajpa.1330680106

Menzies, C. R., 2006. Ecological Knowledge, Subsistence, and Livelihood Practices. In: C. R. Menzies, ed. Traditional Ecological Knowledge and Natural Resource Management. Lincoln, NE and London: University of Nebraska Press, 87-106.

Montgomery, J., 2010. Passports from the past: Investigating human dispersals using strontium isotope analysis of tooth enamel. Annals of Human Biology, 37 (3), 325-346. Doi: 10.3109/03014461003649297

Nordal, S., 1990. Icelandic Culture. Ithaca, NY: Cornell University Library.

O'Connor, T. P., 2010. Livestock and deadstock in early medieval Europe from the North Sea to the Baltic. Environmental Archaeology, 15 (1), 1-15. Doi: 10.1179/146 141010X12640787648512

Ogilvie, A. E. J., et al., 2009. Seals and Sea Ice in Medieval Greenland. Journal of the North Atlantic, 2 (1), 60-80.

Pálsdóttir, A. H., 2008. The Tjarnargata 3c archaeofauna: The Fishing industry and the rise of urbanism in early modern Iceland. In: P. Béarez, S. Grouard, and B. Clavel, eds. Archéologie Du Poisson: 30 Ans D'Archéo-Ichtyologie Au $C N R S$. France: Association pour la Promotion et la Diffusion des Connaissances Archéologiques, 111-124.

Rastrick, Ó., 2021. Physical Impairment and the Spatial Dimensions of Everyday Life in Rural Households in Pre-Industrial Iceland. In: J. G. Rice and H. B. Sigurjónsdóttir, eds. (See Title X). Routledge, (See Chapter X). 
Renwick, R., Yoshida, K., Eacrett, E., and Rose, N., 2016. Meaning of Staring and the Starer-Staree Relationship Related to Men Living with Acquired Spinal Cord Injuries. American Journal of Men's Health, 12 (2), 283-291. Doi: 10. $1177 / 1557988316632297$

Ricaut, F. X., et al., 2004. Genetic analysis of a Scytho-Siberian skeleton and its implications for ancient central Asian Migration. Human Biology, 76 (1), 109-126. Doi: 10.1353/hub.2004.0025

Roberts, C. A., 2000. Did they take sugar: The use of skeletal evidence in the study of disability in past populations. In: J. Hubert, ed. Madness, Disability and Social Exclusion: the archaeology and anthropology of difference. London: Routledge, $46-59$.

Russell, N., 2012. Social Zooarchaeology: Humans and animals in prehistory. Cambridge: Cambridge University Press.

Smith, H., Marshall, P., and Pearson, M. P., 2001. Reconstructing House Activity Areas. In: U. Albarella, ed. Environmental Archaeology: Meaning and Purpose. New York: Springer, 249-270.

Steele, J., 2000. Skeletal indicators of handedness. In: M. Cox and S. Mays, eds. Human osteology in archaeology and forensic science. London: Greenwich Medical Media, 307-323.

Swanson, R. N., 1998. Angels Incarnate: Clergy and Masculinity from Gregorian Reform to Reformation. In: D. M. Hadley, ed. Masculinity in Medieval Europe. Woman and Men in History Series. Boston: Addison Wesley Longman, 160-177.

Temple, D. H., Nakatsukasa, M., and McGroarty, J. N., 2012. Reconstructing patterns of systemic stress in a Jomon period subadult using incremental microstructures of enamel. Journal of Archaeological Science, 39 (5), 1634-1641. Doi: 10.1016/j.jas.2011.12.021

Thorláksson, H., 2000. The Icelandic Commonwealth Period: Building a New Society. In: W. W. Fitzhugh and E. I. Ward, eds. Vikings: The North Atlantic Saga. Washington DC: Smithsonian, 175-185.

van Beek, G. C., 1983. Dental morphology - an illustrated guide. Bristol, UK: Wright PSG.

Villotte, S., et al., 2010. Enthesopathies as occupational stress markers: Evidence from the upper limb. American Journal of Physical Anthropology, 142 (2), 224-234. Doi: 10.1002/ajpa.21217

Voerkelius, S., et al., 2010. Strontium isotopic signatures of natural mineral waters, the reference to simple geological map and its potential for authentication of food. Food Chemistry, 118 (4), 933-940. Doi: 10.1016/j.foodchem.2009.04.125

Weiss, E., 2004. Understanding muscle markers: Lower limbs. American Journal of Physical Anthropology, 125 (3), 232-238. Doi: 10.1002/ajpa.10397

Westerdahl, C., 2013. The Maritime Cultural Landscape. In: B. Ford, D. L. Hamilton and A. Catsambis, eds. The Oxford Handbook of Maritime Archaeology. Oxford: Oxford University Press, 732-762. 


\section{Afterword}

The "Disability before Disability" project, which generated the research upon which this volume is based, included a series of research questions as part of its original funding proposal. However, the project was never intended to present a definitive statement on the history of disability in Iceland, but was more exploratory, perhaps experimental, in nature: putting together different sources of data and scholars and students from different disciplinary backgrounds in order to see what could be produced about a subject that has received little scholarly attention in Iceland. The application for funding was approved though the reviewers, and some of our colleagues, raised a few concerns which we also shared: That the timeline was overly ambitious (starting from the Age of Settlement [874 to 930] until the [1936] Law on Social Security which is the first time that disabled people were referenced in Iceland as a legal or administrative category), and that there were perhaps too many disciplines involved and varied or incompatible forms of data. If the project was indeed a traditional research project, and the success or failure of which hinged upon proving, disproving, or modifying a hypothesis or specific set of hypotheses, then $\mathrm{DbD}$ would be doomed to fail. The formal questions we devised acted more as a guideline for our team, some of whom have not worked in the area of disability previously. Ultimately, we wanted to see what they would find and bring to light, and what they could not find or what was missing, as well as the challenges that may emerge throughout the process. We did not know exactly where the project would lead us, which was simultaneously exciting but also somewhat frightening in an era of contemporary funding regimes in which scholars are supposed to produce carefully planned and packaged "deliverables." At the start much was unknown, and arguably still is.

We count among our successes, on a very basic level, the stories about disabled people from the past and their lives and contributions that have long remained hidden and which are presented in these pages. The material has always "been there," in a manner of speaking, whether in the form of material remains or entries in the archives or within the text of the Sagas, but presented here in a more accessible format and analysed through the lens of disability studies in collaboration with different schools of scholarly 


\section{Afterword}

knowledge. Along with bringing this material to light the authors also present a range of methodological and theoretical approaches, sometimes putting different perspectives and different forms of data together, sometimes challenging and re-framing what was written about disabled people in the past. At times this also meant putting the empirical together with the speculative, or thinking about the ethics of the telling, or re-telling, or re-imagining of the stories of people long past. Or exploring what is not there and missing or absent, and what can be done to make up for these omissions.

As editors we have learned a great deal about what is possible, and what is challenging to do; what different disciplines can learn from disability studies, and what disability studies can learn from different disciplines. We have learned some of the limitations of the data, but also the wealth of data that remains unexplored. Most importantly, we have learned about the potentialities of this kind of research and the value of scholarship into disability before disability and are pleased to see this project act as a springboard for future collaborations.

Hanna Björg Sigurjónsdóttir and James Rice. Reykjavík, June 2021. 


\section{Index}

Note: Page numbers followed by 'n' refer to notes

ableism 3,61

absencepresence concept 95, 98-99, 106-108; crips and misfits 99; disabled people and museum, histories 100-103; matters of absence 103-106; and matters of responsibility $107-108$

agential realism 105, 107

Ahmed, S. 97, 103

Alaimo, S. 104

American Historical Review 54n2

Á mörkum mennskunnar. Viðhorf til

förufólks í sögnum og samfélagi 85

Andrésson, B. 89

archaeological contexts 29-42, $170-172$

archaeological investigations 163, 164, $166-168$

Árnason, Jón Júlíus 89, 154, 155, 159

Árni Jakobsson of Víðasel, case study 137-141

Ásmundsson, Ásmundur 135

attitude, people 58-73; Bíbí and Alda, childhood friends 64-65; confirmation 70-71; critical disability studies 60-61; education and reading lessons 69-70; historical background and literature overview 58-60; interpretation 71-73; methodology 60; prominent men, physicians and clergymen 66; social conditions and important persons, Bíbí's childhood 62-64; source material 61-62; Steini, brother of Bíbí 65-66; stigmatised impact and diagnosis 66-68 autobiography 7, 8, 53, 58, 60-67, 69, 71,72 baðstofa 131, 132, 137-142

Barnes, C. 4, 149

Barthes, R. 90

Benediksdóttir, Sigríður 8, 76, 77; in life 79-84; narrative afterlife of 86-88; in photos 88-90; versus Stutta-Sigga 76-92

Benediktsson, Kristján 136

Berg, Friðgeir 84

Bergsdóttir, Arndís 7

Bergpórsson, Guðmundur 146-160; 19th century folk legends 154-160; childhood disability 151-154; early years and family background 147-148; magical healing 151-154; mother's curse and dwarf's flight 154-160; understandings of disability $148-151$

Bérubé, M. 123

Bíbí's autobiography 58, 60, 61, 68, 70-73

biographical approach 48-51

biological sex 165

Bjarnadóttir, Guðrún 135

bodied people 163, 165, 169, 174

bodily impairments $8,29-31,41,135$

Böðvarsson, Porgils skarði 35

Bogdan, R. 59

Bolu-Hjalmar 155

bones 32,33 , 38, 40, 41, 163-166, 168, 170,171

Bragg, L. 12

Brown, M. 142

Brynhildsvoll, K. 12

Chambers, E. 103

childhood disability 151, 160 
comic relief 17

comorbidities 39-40

Craigie, W. 149

critical disability studies 2, 58, 60-62,

72,73

cross-cultural translation 4

Davidsson, O. 153

Davis, L. 4

Delin, A. 102

Denmark 6

depositories 96, 97, 100-102

dichotomies 104, 105, 108

Disability before Disability (DbD) 1, 2, $5,6,181$

disability studies perspective $1,8,12$, 113

disabled activists 2

disabled bodies 99, 100, 102, 106

disabled people's histories 98, 101, 102, 107

domestic space 132-134

Dundes, A. 152

dwarf legends 158

East Iceland 8, 30, 32

Ebenezersdóttir, Eva Pórdís 8

echinococcus granulosus 37-39

economic hardships 6

Edgerton, R. 59

Egils saga einhenda ok Ásmundar berserkjabana 159

Eiríksson, Hallfreður Örn 85

Eldjarn, T. 153

Eley, G. 48

Euro-American framework 3

farming 5, 129

farmsteads 129, 132, 137, 141, 151, 167

feminist intersectionality framework 58

femoral fractures 40

fictive osteobiographical narrative 163-177; archaeological investigations 166-168; artefacts and environment, structural pieces 166-168; background puzzles 168-170; bones 165-166; ethical considerations 171-172; fractured puzzle, visible image 175-176; Grímur, puzzle assembling 172-174; Grímur's story 174-175; legal, religious documents and sagas 168-170; missing puzzle pieces $170-171$
Finkelstein, V. 128, 130

fishing 5

folk narrative study $146-160$

fractures 33, 40, 41, 164, 165

Francis, A. 156

Friðriksdóttir, J.K. 20

friendship 64, 65, 119-122, 148

Garland-Thomson, R. 99, 106

Garland-Thomson, R., 98

Gislason, S. 155

Gleeson B. 135

Göngu-Hrólfs saga 159

Grímur, 163, 166, 169-172, 174

Gunna fótalausa 135

Gunnell, T. 154

Gunnlaugsson, Gísli Ágúst 6, 129

Hackett, C. J. 36, 39

hagiographic narratives 15, 21

Haraldsson, Haraldur Pór Hammer 7

Haraway, Donna 108

Harðar saga ok Hólmverja 155

healing care 114, 116, 119, 121-124

Hekman, S. 104

historical perspective 1, 3-9, 46, 48, 58, 98-100, 106, 108, 134

historical scholarship 50, 51

historical sources 77-79

Hnjótur 95

Hughes, B. 4

hydatid disease 33, 37-39

hydatid infections 38

Iceland 1, 5, 6

Icelandic Disability Alliance 96

Icelandic peasant society 135,138

identity machines 14

impairments 2, 4, 5, 7, 29-32, 39, 71, 129, 131, 133-136, 141, 150, 169

Imrie, R. 133, 138

intellectual disabilities 2, 8, 52, 53, 58-60, 77

intellectual impairments 16,17

intersectionality 60

Íslendingasögur 13, 14, 22

Íslenzkar pjóðsögur 153

Jakobsson, Á. 137

Jonasson, J. 153

Jónsson, Andrés 147, 148, 150, 151, 154 , 157

Jónsson, J. 85, 131, 132 
Jónsson, Margeir 84

Journal of Social Archaeology 54n1

Kanerva, K. 115

Karlsson, G. 131

Knudson, K. J. 30

Konradsson, G. 153

Kristjánsdóttir, Bjargey 53

Kristján "The Legless," case study 135-137

Lassen, A. 12

Lepore, J. 49

Levi, G. 48

literary symbolism 124

love $63,120,122,146,148,171$

Magnússon, Sigurður Gylfi 7, 53n1, $54 \mathrm{n} 3,68$

maritime archaeology studies 167

materialities 99, 104, 105

Medieval Iceland 12-24; ability, issue of 17-20; healing the body 114-117; health, healing, and social body in 113-124; narrating difference 20-23; narrative sources 13-14; social body 119-122; terminology 14-17; whole body $117-119$

Medieval Icelandic Literature 1, 7, 8, 159

medieval Icelandic sagas $8,13,20$

medieval sagas $8,14,18,20,21,23,24$, $114-118,123$

Metzler, I. 20

Michalko, Rod 76

micro/bio research 46-54; individual, research target 47-48; singularization of history 48-50; "slow" process narrative 51-53

micro historians $48,49,51,52$

microhistory 46-51, 58, 60, 62, 73, 76; biographical approach 50-51; intellectual development of 46-47

Miles, M. 4, 5

Mitchell, D. T. 21, 103

mobility impairment 37-39

museum practices 99, 100, 102, 107

museums 95-105, 107, 108

Mycobacterium tuberculosis 39

narrative prosthesis 21

National Museum of Iceland 35, 96, 97 , 100
Nordic welfare systems 3

Norse settlers 5

North America 2

Ólafsdóttir, Sólveig 7, 8

Oliver, M. 3, 149

One Story, One Person-The Importance of Micro/Bio Research for Disability Studies 7

Ortner, D. 36, 40

osteobiographical context 29-42

Ott, K. 101

Overing, G. 12

Paget's disease of bone (SKR 174) 33, $40-41$

paupers 6

physical impairments 31, 134-135

political activism 2

poverty 6

public historical narratives 98

public records 61

Quetelet, Adolphe 4

Rastrick, Ólafur 7

reality effect 13

responsibilities 6, 99, 103, 107, 131

Rethinking History 54n3

Reykjavík 95

rich cultural response 12

Roberts, C. A. 40, 175

Ronen, M. 18

Rosenwein, B. 65

Ruggiero, G. 46

rural household centrality: in preindustrial Iceland 129-132

Saga Age 13

Saga narratives 14,122

sagas $5,13,14,16,17,20-23,114-116$, $118-121,123,124,169,174$

Sewell, W. H., Jr. 47

Sexton, John 21

Sexton, J. P. 12, 118

Shakespeare, T. 113, 128, 130, 131, 150

Shalinsky, A. 152

Sheppard, Alice 123

Sigmundsson, F. 147, 150

Sigurðsson, Jón S. 135

Skógar museum 95, 103

SKR 128 37-39

SKR 130 39-40 


\section{Index}

Skriðuklaustur monastery 32-33, 42; cases from 33-35

Snyder, L.S. 21

Snyder, S. L. 103

social model 2

social phenomenon 2

Sogutattr fra Gudmundi skaldi Bergtorssyni 148, 153

Spiegel, G. M. 54n3

Stark, L. 153

Stefánsdóttir, Guðrún Valgerður 7

Stojanowski, C. M. 30

Sturlung Age 14

Sturluson, S. 153, 159

Stutta-Sigga 8, 76, 78, 84-88, 90; in legends 84-85

Súrsson, Gísli 21

Taylor, S.J. 59

Titchkosky, T. 103, 141
Titchkosky, Tanya 76

traumatic injury 39-40

treponemal disease (probable venereal syphilis) (SKR 23) 33, 35-37, 39,40

tuberculosis 37-39

Tucker 37

turf-houses 128, 129, 131-134, 141, 142; domestic space and vernacular architecture of 132-134; physical impairment and everyday life in 134-135

universal design (UD) 134

vernacular architecture 132-134

work 7-9, 48, 49, 51, 61, 66, 67, 77, 83, $101,130,151,154$ 